\title{
In en vanuit het verpleeghuis : samenwerking verpleeghuisarts-huisarts
}

Citation for published version (APA):

Schols, J. M. G. A. (2000). In en vanuit het verpleeghuis : samenwerking verpleeghuisarts-huisarts. [Doctoral Thesis, Maastricht University]. Vèrse Hoeven. https://doi.org/10.26481/dis.20000324js

Document status and date:

Published: 01/01/2000

DOI:

10.26481/dis.20000324js

Document Version:

Publisher's PDF, also known as Version of record

\section{Please check the document version of this publication:}

- A submitted manuscript is the version of the article upon submission and before peer-review. There can be important differences between the submitted version and the official published version of record.

People interested in the research are advised to contact the author for the final version of the publication, or visit the DOI to the publisher's website.

- The final author version and the galley proof are versions of the publication after peer review.

- The final published version features the final layout of the paper including the volume, issue and page numbers.

Link to publication

\footnotetext{
General rights rights.

- You may freely distribute the URL identifying the publication in the public portal. please follow below link for the End User Agreement:

www.umlib.nl/taverne-license

Take down policy

If you believe that this document breaches copyright please contact us at:

repository@maastrichtuniversity.nl

providing details and we will investigate your claim.
}

Copyright and moral rights for the publications made accessible in the public portal are retained by the authors and/or other copyright owners and it is a condition of accessing publications that users recognise and abide by the legal requirements associated with these

- Users may download and print one copy of any publication from the public portal for the purpose of private study or research.

- You may not further distribute the material or use it for any profit-making activity or commercial gain

If the publication is distributed under the terms of Article $25 \mathrm{fa}$ of the Dutch Copyright Act, indicated by the "Taverne" license above, 


\section{IN EN VANUIT HET VERPLEEGHUIS}

\section{SAMENWERKING VERPLEEGHUISARTS-HUISARTS}


Omslagontwerp proefschrift; beeldverklaring door de kunstenaar:

"Het idee om juist een foto als visueel herkenbaar gegeven te nemen, kwam voort uit de volgende gedachtegang. Een foto geeft de werkelijkheid heel direct. weer; zij geeft de sfeer aan, waarin iemand leeft. Verder geeft het. verbeelden door een foto de gelegenheid om met het beeld te manipuleren, waarmee het geheel de lading krijgt die het moet hebben.

Het logo van de Riethorst, als "open" gedeelte centraal in de foto, is het begin van. een verandering; zowel in het beeld als scheidsiijn, als met het oog op de start van een nieuwe, zich verder ontwikkelende kijk op zorg. Vandaar ook de visuele verandering in de foto zelf, van het "grijze" gebied (de verouderde visie) naar het levendige, kleurrijke gebied (de nieuwe visie van meer complete zorg op maat). Deze verandering heeft ook zijn uitwerking op de omgeving en krijgt vorm in de toepassing van een kleurenverloop. Het allesomvattende kader van gele en grijze vlakken geeft weer dat een nieuwe visie haar oorsprong heeft in het verleden".....

Peter Nuyten (14-12-1959):

Peter Nuyten is beeldend kunstenaar. Hij is werkzaam als vakdocent beeldende vorming en ook als activiteitenbegeleider in de Riethorst. Als beeldend kunstenaar is hij vooral bezig met de klassieke schildertechnieken, die hij met name gebruikt bij het schilderen van stillevens. Daarbij blijken de sfeer en de expressie van het dagelijkse voorwerp hem enorm te boeien.

Als activiteitenbegeleider tracht hij voortdurend op een cliẻntgerichte wijze vorm te geven aan een zinvolle dagbesteding van zorgvragers.

\begin{tabular}{|c|c|}
\hline \multirow{4}{*}{$\begin{array}{l}\text { Aureur: } \\
\text { Uitgever: }\end{array}$} & Jos MGA Schols \\
\hline & Vèrse Hoeven uitgeverij \\
\hline & Haydnstraat 2 - 4941 AE Raamsdonksveer \\
\hline & Tel. (0162) 514357 Fax: (0162) 518654 \\
\hline Vormgeving: & Cecilia Verhaar-Martens \\
\hline Fotografie omslag: & René Weterings \\
\hline Illustratie omslag: & Peter Nuyten \\
\hline Drukwerk: & Drukkerij Dombosch, Raamsdonksveer \\
\hline
\end{tabular}

Eerste druk februari 2000

ISBN 9075703074 / NUGI 757

(C) 2000 Jos MGA Schols

Niets in deze uitgave mag worden verveelvoudigd en/of openbaar gemaakt door middel van druk, fotocopie, microfilm of op welke andere wijze ook, zonder voorafgaande schriftelijke toestemming van de uitgever. 


\title{
IN EN VANUIT HET VERPLEEGHUIS \\ SAMENWERKING VERPLEEGHUISARTS - HUISARTS
}

\author{
Proefschrift
}

ter verkrijging van de graad van doctor aan de Universiteir Maastricht, op gezag van de Rector Magnificus, Prof. dr. A.C. Nieuwenhuijzen Kruseman, volgens het besluit van het College van Decanen, in het openbaar te verdedigen op vrijdag 24 maart 2000 om 14.00 uur

door

Joseph Marie Gerardus Andreas Schols geboren te Valkenburg-Houthem, 1957 


\section{Promotoren:}

Prof. dr. HFJM. Crebolder

Prof. dr. F. Sturmans (Erasmus Universiteit Rotterdam)

Co-promotores:

Dr. JPM. Diederiks

Dr. RTCM. Koopmans (Katholieke Universiteit Nijmegen)

\section{Beoordelingscommissie:}

Prof, dr. J. Troost (voorzitter)

Prof. dr. PP. Groenewegen (Universiteit Utrecht en NIVEL. Utrecht)

Prof. dr. C. Spreeuwenberg

Prof. dr. Th. B. Voorn (Universiteit Utrecht)

Dr. F. Stevens

Het ondernock. gepresenteend in dir procfichrift is ondergebracht bij de onderzocksinstituten Ex Tra en Health, die onderdecl uitmaken van de ondernocksschool CARE, welke in 1995 werd erkend door de Koninklijke Nederlandse Academie van Wetenschappen (KNAW).

Het project wend mede begeleid door het NIVEI te Utrocht.

Financiele ondersteuning voor de uitwering van het onderwok naar de sumenwerking russen verplecghuisarts en huikurs werd verkregen van Stichting de Ricthorst te Geertruidenberg.

In de drukksosten van het procfichrifi wend bujgedragen door:

Jansen-Cilag, Nutricia, ConvaTec, Searke, Pfizer en SmithKline Beecham. Eveneens door Brocacef, de Secdeliphe Godahuiaen te Gecrtruidenberg en de Verse Hocven te Ramadonksveer. 


\section{INHOUDSOPGAVE}

Deel 1. Algemene inleiding, vraogstellingen en opbouw proefschrift

1.1 Achtergrond 8

1.2 Vraagstellingen 9

1.3 Uitwerking van vraagstellingen en opbouw proefschrift 9

Deel 2. Vanuit institutionele zorgverlening naar extramurale zorgverlening 11

2.1 Inleiding: Verplecghuisgeneeskunde en verplecghuiszorg in kort 12 historisch perspectief

2.2 Opname in een verpleeghuis: nood of deugd? 19

2.3 Verplecghuiszorg buiten de muren: dagbehandeling, consultatic $\quad 27$ en substitutieprojecten

2.4 Verplecghuiszorg in beweging; een inventariserend overzicht van 39 vijf substitutieprojecten verplecghuiszorg

2.5 Verplecghuisdagbehandeling: een groeiende functie voor een tamelijk vast omschreven doelgroep

Deel 3. De samenwerking verpleeghuisarts - huisarts nader onderzocht

3.1 Inleiding

3.2 Samenwerking tussen huisarts en verplecghuisarts. Twee actoren in een veranderende ouderenzorg

3.3 Contacten tussen verplecghuisarts en huisarts. Frequentie, aard en inhoud

3.4 Variatie in samenwerkingsintensiteit tussen verpleeghuisarts en huisarts in Nederland

3.5 Nadere beschouwing van de samenwerking tussen verpleeghuisarts en huisarts; variatic in continuiteit van medische zorg gerelateerd aan diverse samenwerkingsvariabelen

Deel 4. Beschouwing en samenvatting

4.1 Beschouwing en aanbevelingen

4.2 Samenvatting

4.3 Summary 
versus HCTZ/captopril; een onderzoek bij oudere hypertensiepatiënten

Schols JMGA, Rila HJ, Boermans AJM, Kampen PA van, Leijten PA. Tijdschr Geneesm Onderzoek/ Journal for Drugtherapy and Research 1992;17:231-5

2. Slaapproblemen en slaapmiddelengebruik in een verplecghuis

Een inventariserend onderzoek

Schols JMGA. Tijdschr Gerontol Geriatr 1991;22:139-42

3. Slaapproblemen bij verpleeghuispatiënten; de effectiviteit van zopiclon

Schols JMGA, Meij N van der. Tijdschr Geneesm Onderzoek/ Journal for Drugtherapy and Research 1993;18:222-6

4. Toegenomen sterfte van verpleeghuispatiënten bij extreme buitentemperatuur; toename groter bij hitte dan bij koude Borst V, Schols JMGA, Mackenbach JP. Ned Tijdschr Geneeskd 1997; 141(45):2180-3

5. Weefseldonatie in verpleeghuizen:-een oriëntatie op het aantal potentiële donoren en de kennis en attitude van verpleeghuisartsen en -directies

Schols JMGA, Berendschot-de Lange DC. Ned Tijdschr Geneeskd 1999;143(22):1153-7 


\section{ALGEMENE INLEIDING, VRAAGSTELLINGEN EN OPBOUW PROEFSCHRIFT}




\subsection{ACHTERGROND}

In de afgelopen decennia heeft de Nederlandse verpleeghuissector zich sterk ontwikkeld. Het hedendaagse verpleeghuis telt een breed spectrum aan zorgfuncties waaronder revalidatie/reactivering, langdurige zorg, terminale zorg, observatie en diagnostiek, consultatie en advies, tijdelijke opvang en crisisinterventie.

Voor de uitoefening van deze zorgfuncties is, naast het verplegend en verzorgend personeel voor de 24-uurs basiszorg, een scala aan vakdisciplines aanwezig, op (para)medisch en psychosociaal gebied.

Het intrinsieke zorgconcept wordt daarbij gekenmerkt door een continue, langdurige, systematische en multidisciplinaire geïntegreerde zorgverlening, die tot stand komt in samenspraak met de patiënt en diens verwanten. ${ }^{1.2}$

Ook al zijn ze niet exclusief voor hen bedoeld, getalsmatig vormen ouderen toch de belangrijkste doelgroep van verpleeghuizen. Binnen de verpleeghuissector is dan ook deskundigheid ontwikkeld op het terrein van de behandeling, verpleging en begeleiding van ouderen.

Intramuraal ligt het accent heden ten dage op de verbetering van de kwaliteit van zowel het woonklimaat als de zorgverlening zelf.

Demografische ontwikkelingen, capacitaire en budgettaire problemen in de gezondheidszorg, overheidsvisies en veranderende wensen van de zorgvragers zelf hebben ertoe bijgedragen dat verpleeghuizen zich de afgelopen tien jaar niet alleen steeds meer semimuraal, maar ook buiten de eigen muren, extramuraal, zijn gaan profileren.

Hierdoor kan een steeds groter aantal zorgbehoevende ouderen thuis of in de 8 verzorgingsbuizen profiteren van de mogelijkheden die het hedendaagse verpleeghuis te bieden heeft.

Het is vooral ook extramuraal dat verpleeghuisdisciplines, zoals de verpleging en de verpleeghuísgeneeskunde én eerstelijns disciplines, waaronder de thuiszorg en de huisartsgeneeskunde, elkaar ontmoeten en elkaar complementair, door een goede samenwerking kunnen versterken. Deze onderlinge samenwerking maakt dat we vervolgens niet meer spreken van vaak eenzijdig gerichte extramuraliteit doch van gezamenlijk vormgegeven transmurale zorg.

In de definitie van de Nationale Raad voor de Volksgezondheid (1995) wordt onder transmurale zorg verstaan: "vormen van zorgverlening die, toegesneden op de behoefte van de veelal in de thuissituatie verblijvende patiënt met complexe zorgproblematiek, plaatsvinden op basis van samenwerking, afstemming en regie tussen specialistische en generalistische zorgverleners, waarbij sprake is van een gemeenschappelijke verantwoordelijkheid met expliciete deelverantwoordelijkheden".

Transmurale zorgverlening kan daarbij echelonoverstijgend plaatsvinden in bijvoorbeeld het traject tussen ziekenhuis en thuiszorg, tussen ziekenhuis en verpleeghuis en tussen verplecghuis en thuiszorge

Men spreekt in dit verband ook wel van ziekenhuisverplaarste zorg en verpleeghuisverplaatste zorg.

Daar waar de verplecghuiszorg in algemene zin en de verpleeghuisgeneeskunde in het bijzonder, op dit moment, de eerstelijnszorg ontmoeten, ontstaan ook aanknopingspunten voor nader wetenschappelijk onderzock. Deze aanknopingspunten hangen samen met de vnaagzijde (bijvoorbeeld de capaciteitsproblemariek en de zorgbehoeften van zorgvragers), met de aanbodzijice (bijvoorbeeld de 
kwaliteit en doelmatigheid van zowel de verplecghuiszorg als de eerstelijnszorg en het ontwikkelen van alternatieve, transmurale zorgvoorzieningen), met het fenomeen van de transmunale samenwerking in de zorg en ook met betrekking tot de structuur en het beleid van de gezondheidszorg.

\subsection{VRAAGSTELLINGEN}

In het verlengde hiervan betreffen de in dit proefschrift beschreven onderzoeken de volgende vraagstellingen:

1. Welke doelgroepen maken gebruik van de verplecghuiszorg (intra-, semi- en extramuraal)?

2. Welke zijn de effecten van de verplecghuiszorg op de onder I. genoemde doelgroepen?

3. Hoe staat het met de (transmurale) samenwerking tussen disciplines uit het verpleeghuis en disciplines daarbuiten?

\subsection{UITWERKING VAN VRAAGSTEL.LINGEN EN VERDERE OPBOUW PROEFSCHRIFT}

Aspecten die samenhangen met de eerste twee vraagstellingen worden behandeld in deel 2. getiteld "Van institutionele zorgverlening naar extramurale zorgverlening", Na een inleiding (paragraaf 2.1), waarin een kort historisch perspectief wordt geboden, wordt in paragraaf 2.2 ter introductie een klinische les gepresenteerd. In paragraaf 2.3 worden de mogelijkheden van de verplecghuiszorg buiten de muren beschreven.

Paragraaf 2.4 bevat het verslag van een inventariserend onderzoek naar de effecten van een aantal substiturieprojecten. verplecghuiszorg in verzorgingshuizen.

In paragraaf $2.5^{4}$ Verplecghuisdagbehandeling: een groeiende functie voor een tamelijk vast omschreven doelgroep" wordt het profiel van somatische en psychogeriatrische dagbehandelingspatiënten beschreven bij aanvang, respectievelijk ontslag van hun dagbehandeling.

Deel 3 van het proefschrift gaat nader in op de samenwerking tussen verpleeghuisarts en huisarts en past daarmee binnen het kader yan de derde vraagstelling, In paragraaf 3.2 wordt, na een beschrijving van de veranderingen in de ouderenzorg, in algemene zin ingegaan op de samenwerking tussen verpleeg. huisarts en huisarts.

Paragraaf 3.3 bevat het verslag van een inventariserend onderzoek naar de frequentie, aard en inhoud van contacten tussen verplecghuisartsen en huisartsen in de regio Oosterhout/Dongemond (Noord-Brabant).

In paragraaf 3.4 wordt een onderzock gepresenteerd naar de intensiteit van de samenwerking tussen verpleeghuisartsen en huisartsen in Nederland.

Paragraaf 3.5 beschrijft de invloed van diverse determinanten op geconstateerde verschillen in continuïteit van medische zorg in de as huisarts - verpleeghuisarts.

Deel 4 bevat de beschouwing, aanbevelingen en samenvatting/summary.

\section{ADDENDUM}

In een addendum wordt een vį̣ftal artikelen weergegeven, waarin verslag gedaan wordt van enkele kleinschalige, patiëntgebonden verpleeghuisgeneeskundige onderzocken. 


\section{LITERATUUR}

1. Nederlandse Vereniging voor Verplecghuiszorg. Verplecghuizen op de zorgmarka(nr. 592.004).

Utreche: NZI, 1992.

2. Ribbe MW, Wegen in de verplecghuisgeneeskunde. Oratie. Amsterdam: VU, 1991.

3. Nationale Rad voor de Volksgerondheid (NRV). Advies transmurale somatische zorg. NRV, 1995.

4. Fontein P. Transmurale zorg inleiding, In Crebolder HFJM e.a. (red). Handboek Thuiszorg (HAT). Utrecht: De Tijidstroom, 1997: B 9.1-1/13.

5. Spreeuwenberg C. (Ner)werken voor chronisch zieken. Oratie. Maastricht: Rijksuniversiteit Limburg, 1994.

6. Veer AJE, Kerkstra A. Verpleeghuiszorgonderzocke stand van zaken en relevante onderzocksvelden. NIVEL rapport, Utrecht: NIVEL. 1997. 


\section{VANUIT INSTITUTIONELE ZORGVERLENING NAAR EXTRAMURALE ZORGVERLENING}




\section{INLEIDING VERPLEEGHUISGENEESKUNDE EN VERPLEEGHUISZORG IN KORT HISTORISCH PERSPECTIEF}


Alvorens de professionele medische hulp aan de oude, gebrekkige, langdurig of ongeneeslijk zieke medemens te kunnen aanmerken als verpleeghuisgeneeskunde, als een onderdeel van onze specialistisch denkende geneeskunde, moeten we ons realiseren dat daar een lange weg aan vooraf ging. Die weg moeten we dan nog niet situeren in de sfeer van de geneeskunde, maar eerder in het kader van de zorg, c.q. verzorging. Waar zich bij de reguliere geneeskunde bepaalde terreinen, of onderdelen daarvan, door een zekere verdieping onderscheiden van de algemene, de generalistische, geneeskunde, is dit bij de verpleeghuisgeneeskunde enigszins anders gegaan. De wortels van de verpleeghuisgeneeskunde moeten we zoeken in de wereld van de zorg. Zorg heeft de mens altijd gekend; zorg voor de hulpbehoevende medemens, die, ziek zijnde, van de gemeenschap werd afgezonderd of zich daar zelf van isoleerde om zo zijn einde tegemoet te gaan; een zeker animaal oerinstinct dat zijn einde zoekt in volledige afzondering. Bij de mens heeft van oudsher de behoefte geleefd de lijdende bij te staan en te trachten diens pijnen te verzachten. In die zin liggen de wortels van de verpleeghuiszorg dan ook reeds in een ver verleden, zij. het dat zij eigentijds en onder verschillende benamingen werd verleend door diverse zorggevers, variërend van priesters in de tempels, tot slaven, monniken en later door min of meer professioneel ingestelde leken. Dat gebeurde herzij op eigen initiatief, hetzij op instigatie van welgestelden of religieuze instellingen; ieder met hun eigen motieven. Medische hulp kwam daarbij incidenteel van de kant van zogeheten heelmeesters, zij her dat ogk zij doorgaans mensen waren die "her vak" in de prakrijk hadden. geleerd.'

14 In samenhang met de maatschappelijke ontwikkelingen, zoals de overgang van de landbouwmaatschappij naar de industriële samenleving " de opkomst van de steden, de verzelfstandiging van de burgers en de verbetering van de onderwijsmogelijkheden, zien we ook een ontwikkeling op het tersein van de zorg en de mogelijkheden op medisch gebied. ${ }^{2}$ Langzamerhand groeiden beide als het ware uiteen. Dit laatste bleek hoe langer hoe meer het geval, toen de genezers via regulier onderwijs en zelfs via de universiteit tor geschoolde vakmensen werden opgeleid. Zieke en geriatrische patiènten waren voor hen op de eerste plaats interessant wegens hun onderliggende (somatische) aandoeningen. $\mathrm{Om}$ daartegen echt iets te kunnen ondernemen waren andere instellingen nodig dan de al dan niet geprivatiseerde tehuizen waarin bij wijze van spreken iedereen over een kam geschoren werd. Er ontstonden heuse ziekenhuizen waar de patiënten zo mogelijk - werden behandeld. De reconvalescentie en revalidatie vonden in toenemende mate - al dan nier succesvol - plaats in de zojuist genoemde tehuizen, die gestaag in aantal groeiden." Aanvankelijk waren ze nog ongedifferentieerd in inrichting en organisatic. Terminale patiënten, ongeneeslijke zieken, ze lagen zo maar door elkaar; bij elkaar gebracht om hun overlijden af te wachten. Waar van de kant van het tehuis geen echte medische hulp meer geboden kon worden, waren zorg en verzorging hoofddoel. Wel kwam er incidenteel een plaatselijke huisarts om "broodnodige" hulp te bieden; niet in het kader of in het perspectief van genezing, maar om het lijden te verlichten; c.q. de wettelijk verplichte handelingen te verrichten in geval van overlijden. Ook al werd zijn betrokkenheid bij een dergelijke instelling groter, zodat er sprake was van een formeel dienstverband, dan nog veranderde zijn taak als medicus nauwelijks.' Zijn bemoeienissen richtten zich veeleer op materiële zaken, zoals de gebouwen en 
hun inrichting. Toch werd langzamerhand het verplecgkundig aspect minder vrijblijvend. Allengs ging het verplegend personeel de in het huis verblijvende zieke mens met andere ogen zien; niet wat er allemaal mis was, maar ook wat er nog te behalen viel aan welzijn, ondanks de doorgaans sombere vooruitzichten. In plaats van een afwachtende houding aan te nemen; letterlijk pappen en nathouden en maar wachten tot de dood er op volgde, gooide men het over een andere boeg." Ook al was men ervan overtuigd dat er van een volledig herstel geen sprake meer kon zijn, kreeg men toch meer oog voor "het toevoegen van leven aan de dagen", dan voor "dagen aan het leven". Voor deze reactivering was echter meer nodig dan verpleging alléén. Naast een beroep op de lichamelijke mogelijkheden, deed men dat eveneens op het geestelijke terrein. Het is duidelijk dat het geboden was hiervoor gekwalificeerde, professionele krachten aan te trekken. Ook de arts, de veronderstelde medisch deskundige bij uitstek, kon hier niet aan de zijlijn blijven staan. Er werden een bredere kijk en inbreng van hem verwacht dan alleen voor de puur medische aangelegenheden. Holistisch bezig zijn veronderstelde immers een persoon die op adequate wijze, als primus inter pares, met zijn medewerkers plannen maakte ten behoeve van de gehele patiënt, behandelingen voorstelde voor de gewenste opties en vertrouwen toonde in ieders deskundigheid en inzet. Er mocht dan ook terecht van hem verwacht worden dat hij zich in zijn vakgebied zo breed mogelijk oriënteerde en zodoende voldoende inzicht verwierf in de paramedische en psychosociale kanten van de behandeling." Dit gold eveneens met betrekking tot de ongeneeslijke, terminale zieke die evenzeer recht heeft op specifieke en specialistische zorg. Lijden en waardig sterven horen bij de waardigheid van de mens, waarbij we ons moeten realiseren dat ook het lijden deel uitmaakt van het leven."

De realisatie van een dergelijke visie ging gepaard met een inbedding in een multidisciplinair kader. Naast de voortgaande professionalisering van de verpleeghuisarts leidde dat tot het werken in teamverband met geschoolde paramedici. Aanvankelijk kende deze werkwijze een tamelijk incidenteel karakter, doch deze werd expliciet en gestructureerd toen in 1972 de Nederlandse Vereniging van Verpleeghuisartsen werd opgericht. In een zich spoedig vormende nauwe band tussen de beroepsgenoten gold als eerste keuze de professionalisering van hun werkzaamheden door onderlinge contacten, waarbij voorop stond dat de verdere beroepsontwikkeling slechts tot resultaat zou leiden als deze plaats zou vinden op basis van een gedegen, wetenschappelijke studie van de gehele verzorgingsproblematiek van langdurig zieken en bejaarden. ${ }^{10}$ Uiteraard beseften de betrokkenen dat zij dit alles niet op eigen kracht konden bereiken; dat hieraan ook vanuit een specifieke opleiding de nodige aandacht besteed zou moeten worden.

Slechts een fundamentele aanpak zou hier dus succes kunnen hebben, waarbij op de eerste plaats gedacht werd aan de officiële erkenning en registratie van het beroep van verpleeghuisarts; een en ander te verwezenlijken na de totstandkoming van een academische opleiding daartoe. Die zou plaats moeten vinden in samenhang met relevant wetenschappelijk onderzoek; onderzoek dus in het kader van de functie van de verpleeghuisarts, voor de patiènt in het verpleeghuis, en over diens hoofd heen, ten dele ook voor diens lotgenoten "buitenshuis" (=extramuraal); lotgenoten waarvan het aantal bij onze dubbelvergrijzende bevolking met de dag groeit. Dit streven leidde in 1980 tot de eerste universitaire leerstoel Verpleeghuisgeneeskunde in Nijmegen, in 1989 tot de eerste opleiding tot verpleeghuis- 
arts in Amsterdam en in 1990 tot de opening van een apart register voor verpleeghuisartsen door de Koninklijke Nederlandsche Maatschappij tot bevordering der Geneeskunst (KNMG).

Een belangrijk moment in de historische ontwikkeling van de verpleeghuiszorg was dat waarop ziekenhuizen niet langer meer onderdak boden aan hun voor hun ziekte uitbehandelde patiënten." Daardoor stonden de verpleeghuizen voor een enorme opdracht om de vele daarvoor in aanmerking komende patiënten op te vangen en te verzorgen. De verpleeghuizen reageerden echter adequaat op die ontstane behoefte en hun daarmee verworven, extra betekenis werd nog vergroot door de AWBZ, de Algemene Wet Bijzondere Ziektekosten (1968), die het voor iedere Nederlander mogelijk maakte opgenomen te worden in een verpleeginstelling. ${ }^{\text {th }}$

Niet alleen voor de potentiële patiënten van het verpleeghuis was dit een groot goed, de uitvaardiging en toepassing van deze wet impliceerden voor de verpleeghuizen de officiële erkenning als instituten binnen de Nederlandse gezondheidszorg. De volgende stap in het professionaliseringsproces van de verpleeghuisgeneeskunde was het op gang brengen van generiek verpleeghuisgeneeskundig wetenschappelijk onderzoek op basis van klinische studies en voorts, van de inbreng van diverse ondersteunende disciplines. ${ }^{\text {thil }}$

Weer een volgende fase betrof het vaststellen van determinanten voor een zo lang en goed mogelijk verblijf van patiënten in hun eigen omgeving. Het binnen de verpleeghuiszorg/-geneeskunde ontwikkelde zorgconcept bleek hier zinvol. ${ }^{12.13}$

Kennis en ervaring stelden het verpleeghuis in staat om hulp te verlenen, aan

16. patiënten thuis of in een verzorgingshuis. Ook de medische aspecten gingen in toenemende mate deel uitmaken van de door het verpleeghuis geboden zorg in de eigen leefwereld van de patiënten. Deze ontwikkeling leidde tot extra aandacht voor de samenwerking met andere disciplines in de eerstelijn. Hierbij dient er onder andere voor gewaakt te worden dat "het verpleeghuis buiten de muren" niet leidt tot een competentieprobleem met de huisarts. ${ }^{14}$ Laatstgenoemde is immers de vertrouwensfiguur van de patiënt en diens gezins- en familieleden. De toename van het aantal ouderen en de daarmee gepaard gaande multimorbiditeit vraagt om nieuwe vormen van zorg en hernieuwde afstemming van de diverse medische en paramedische specialismen. . $^{15.16}$ 


\section{LITERATUUR}

1. Honsmanshoff HF]. De drempel van de ouderdom; medische en sociale mog voor de oudere mens in de Grick-Romeinse Oudheid. Ned Tijductur Genecked 1995; 139 (32): 1651-6.

2. Kok J. Samenlevingen in een stroomversnelling. Demografische, economische en sociale onrwikleclingen. In: Wosscls LHM, Bosch A. (red). Verandende grensen, nationalisme in Furopa 1815.1919, Nijmegen, 1992. $104-64$.

3. Bronts H). Zonneveld RJ van. Een ondernoek naar bestand, vepleogduur en diagnose van de in 1924. 1939 en 1954 in een aantal zickenhuizen opgenomen bejaarden. Her Zickenhuiswesen 1957; 10: 305-14.

4. Robben PBM. Oudere chromsche patiènten en hun voorzieningen in de eerre helf van de rwintigte ecuw. Tijdschr Gerontol Geratr 1998: 29: 168-76.

5. Oostvoged FJG. De historische ontwikkeling van het verplecghuis. In: Trommed J, Rible MW, Stoop JA. (red), Capita Selecta van de Verplecghumgeneeskunde. Utreche/Anrwerpen, 1989: 3-19.

6. Veddhuizen van Zanten-Hyllner M. De geschiodenis van de verplecghuisenesckunde, Vox Hospitii 1988,12 (2): $41-3$.

7. Rapport: Rust- en verpleggrehuizen KNMG. Medisch Contact 1961; 34: 545-8

8. NVVA. Funcricomschrijving en takenpakket van de verplecghuisars. Utrechn NVVA/Berenschot, 1992.

9. Enklaat ). Terminus. Dr. Ben Zylica en de kumut van het serven. Zurphen: Plaraan, 1999

10. Ribbe MW, Ooms ME, Wal Gi van der, Eijk JThM. Wetenschappelijk andernock in de verplecghuiggenees. kunde: een voorwarde voor professionalisering. Ned Tijdsche Genecakd 1995; 139 (36): 1851.5.

11. Jongeneel F. Complese rorg behoefr mulndisciplinaire samenwerking. In. Trommd J, Ribbe MW, Sioop JA. (red) Capita Selecta van de Verplecghungenecakunde, Utreche/Anrwerpen 1989, 115-21.

12. Nederlandse Vereniging voor Verplecghuiszong, Verplecghuizen op de zorgmarke. Nr. 592.004. Utrechr NVVz, 1992.

13. Schols JMGA. Substitutic verplecghuiszorg en consultatiefuncrie verplecphuizent externe activiteiten van het hedendaage verpleeghuis. Modern Medicine 1992:16 (7/8) 619-24.

14. Schols JMGA, Diederiks JPM. Koopmans RTCM. Samenwerking tussen huisarts en verplecghuisarts; twee actoren in een veranderende ouderenzorg. In: Crebolder HFJM e.a. (red). Handbock Thuisrorg (HAT). Utrecht: De Tijdstroom, 1997: B 8.2-1/19.

15. Robben PBM. Olde Rikkert MGM, Hurschemacken GIM. Beroepsvorming in tweevoud: de khnisch geriater en de verplecghuisarts, 1945-1990. Tijduchr Gerontol Geriatr 1999; 30-55-63

16. NVVA/L.HV. Rapport: Arts en Ouderen: uitdagende zorg. Een stap vooruit in de samenwerking tusen huisarts en verplecghuisars. Utrecht: NVVA/LHV, 1998. 


\section{OPNAME IN EEN VERPLEEGHUIS: NOOD OF DEUGD?}

J.M.G.A. Schols, M.W. Ribbe en J.A. Stoop 


\section{Dames en Heren,}

Verpleeghuizen zijn onder meer van de rijksnoodverpleeghuizen en de ziekenboegen van de grotere bejaardenoorden uitgegroeid naar erkende instellingen van gezondheidszorg krachtens de Algemene Wet Bijzondere Ziektekosten uit 1968.' Behalve demografische factoren (de enorme toename van het aantall ouderen) hebben bij deze ontwikkeling ook de functieveranderingen van de zickenhuizen - van langdurige opname naar kortdurende diagnostiek en therapie - een belangrijke rol gespeeld. In de afgelopen dertig jaar heeft een groei plaatsgevonden van 6400 bedden in 1961 naar 52.000 bedden nu (de helft voor somatische en de helft voor psychogeriatrische patiënten).? Daarnaast hebben veel verpleeghuizen een dagbehandeling (in totaal 3300 plaatsen) en zijn er inmiddels bijna 500 substitutieprojecten voor verpleeghuiszorg met meer dan 8000 plaatsen. Aldus is een samengesteld zorgpakket ontstaan voor chronisch zieke, jonge en oude mensen, zowel klinisch (opname in verpleeghuis), ambulant (dagbehandeling) als in de eigen omgeving (substitutieprojecten). ${ }^{36}$ Door het crečren van een dergelijk zorgsysteem is een situatie geschapen die enerzijds uniek. is, omdat behandelingen voortgezet kunnen worden nadat de ziektetoestand als. invaliderend en (of) chronisch is gediagnostiseerd, en anderzijids noodzakelijk, omdat de zorgverlening in het sociale netwerk van de chronisch zieke mens thuis. vaak ontoereikend is. De uit nood ontstane verpleeghuizen blijken nu ook een deugd te kunnen zijn in ons gezondheidszorgsysteem.

Maar dat wordt niet altijd zo ervaren. Voor velen is een verpleeghuis hetzelfde als. een eindstation, waarbij het beeld opdoemt van lichamelijk en geestelijk 'versleten' oude mensen bij wie medisch geen eer en geen verbetering te behalen is. Onder andere aan dit eenzijdige beeld is de tegenzin in opname in een verpleeghuis te wijten. Onbekendheid met de mogelijkheden bij langdurige opname in het verpleeghuis, maar vooral onbekendheid met één van de centrale doelstellingen van het verpleeghuis, namelijk tijdelijke opname voor behandeling en revalidatic, houdt deze beeldvorming in stand.

In deze klinische les stellen wij u enkele patiënten voor, die ervaren hebben dat opname in een verpleeghuis een noodoplossing lijkt, maar toch tot goede resultaten kan leiden.

Patiënt $\mathrm{A}$, een vrouw van 79 jaar, woont heel tevreden alleen op een bovenhuis. Met de buren heeft zij regelmatig contact. Zij is zelfredzaam, maar zowel haar overgewicht als haar pijnlijke knieën bezorgen haar beperkingen. De wijk waarin zij woont, staat bekend als een onrustig gedeelte van de stad, maar veel last heeft zij daar nooit yan gehad. $\mathrm{Zij}$ is een van de oudste bewoonsters in de wijk en men spreekt met respect over haar.

Op oudejaarsavond (een donderdag) wordt er al vrocg feestgevierd en veel vuurwerk ontstoken. Terwijl patiënte in haar keuken melk verwarmt hoort zij beneden aan de voordeur een hevig lawaai. Zij wil gaan kijken, maar struikelt en valt de trap af tot onder aan de voordeur. Opstaan is onmogelijk, boven is de telefoon onbereikbaar en boven staat inmiddels de melk over te koken met veel stoom en rookontwikkeling. Zij bonkt aan de binnenkant van de voordeur en dat trekt de aandacht van voorbijkomende surveillerende agenten. Door de brievenbus vindt het eerste contact plaats. De agenten verschaffen zich toegang tot het huis en waarschuwen de dienstdoende huisarts. Stijf van de pijn en niet. 
in staat zich te bewegen ligt patiënte op de grond. Per ambulance wordt zij naar de $\mathrm{EHBO}$-afdeling van het ziekenhuis vervoerd. Bij nauwkeurig neurologisch en uitgebreid röntgenologisch onderzoek van het skelet worden geen uitvalsymptomen of fracturen aangetoond. Ook bij internistisch onderzoek zijn geen aanwijzingen te vinden voor bloedingen in de borst- of buikholte. De diagnose luidt: 'contusies van het spierstelsel en bindweefsel, voornamelijk in de rug, benen en rechterarm'. Ter behandeling wordt patiënte paracetamol voorgeschreven. Ook adviseert men haar in beweging te blijven, zonodig met wat hulp van een fysiotherapeut. Zij kan gerust naar huis gaan en eventueel de wijkverpleging inschakelen.

'Naar huis gaan?', reageert patiènte, 'Dat kan helemaal niet! Ik kan niets! Alles. doet verschrikkelijk pijn! Kan ik niet hier blijven?' 'Mevrouw', antwoordt de dienstdoende assistent, 'dit is een EHBO-post voor noodbehandeling. Er is geen indicatie voor een spoedopname. Bovendien moeten wij hier met meer spoedgevallen voor opname rekening houden, zeker vanavond! Ons voorstel is: U kunt naar huis - of eventueel tijdelijk naar een verpleeghuis.'

"Maar dokter, ik kan toch zo niet alleen naar huis. ledereen in de buurt is. vanavond en morgen uit! En naar een verpleeghuis? Doe mij dat niet aan, ik hoef toch nog niet dood te gaan?'

Na enig overleg stemt patiënte ermee in om met spoed tijdelijk opgenomen te worden in een verpleeghuis. Daar, laat in de avond aangekomen, wordt zij opgevangen door de verpleging, die de dienstdoende verplecghuisarts erbij haalt. $\mathrm{Na}$ een oriënterend onderzock wordt de volgende dag (nieuwjaarsdag) met de fysiotherapeut een voorlopig zorgplan opgesteld. Pas op maandag 4 januari kan contact worden opgenomen met verschillende instanties en personen (maatschappelij,k werk, wijkverpleging) om een plan voor thuiszorg op te stellen. Gedurende de eerste dagen van het nieuwe jaar is patiënte al veel minder pijnlijk en minder stijf geworden. Zij kan zich met wat hulp redelijk bewegen, maar zelfstandig voor wat betreft de algemene dagelijkse levensverrichtingen (zogenaamd ADL-zelfstandig) is zij nog niet. Nadere aandacht wordt besteed aan haar algemene toestand, vooral aan haar overgewicht $(85 \mathrm{~kg}$ bij een lengte van $1,70 \mathrm{~m}$ ), de pijnlijke kniegewrichten (röntgenologische diagnose: 'gonarthrosis') en een foliumzuurdeficièntie. Alle reden om pariënte wat langer in het verpleeghuis te houden voor behandeling en begeleiding. De verpleeghuisarts overlegt met de huisarts over de gezondheidstoestand en mogelijkheden voor ontslag. Maar patiënte wil graag zo spoedig mogelijk naar huis. Door de maatschappelijk werkster is direct na het begin van de week contact gelegd met het wijkmaatschappelijk werk en met de wijkverpleging. Uiteraard wordt patiënte dagelijks bij de stand van zaken betrokken. Hoewel zij aangeeft dat het haar enorm meevalt in het verpleeghuis en dat het er gezellig en goed toeven is, terwijl zij bovendien aanzienlijk is opgeknapt, geeft zij ook duidelijk te kennen, dat zij zo snel mogelijk naar huis wil gaan. 'Kunt u mij dan niet vanuit het verpleeghuis thuis helpen?' vraagt zij. Er was (in 1982) nog geen formele regeling voor verpleeghuiszorg buiten de muren van het verpleeghuis, zoals de hedendaagse substitutieregeling. Er moest derhalve op de bestaande situatic worden ingespeeld met zelfbedachte oplossingen. Vragen die hierbij opkwamen, waren: welke hulp zal het verpleeghuis in de thuissituatie kunnen bieden, wie zal dan de. verantwoordelijkheid voor de zorg moeten dragen, huisarts of verpleeghuisarts, 
hoe moet de communicatie verlopen en hoe moet de financiering geregeld worden?' Met behulp van de geïmproviseerde verpleeghuiszorg buiten de muren van het verpleeghuis kan tegemoet gekomen worden aan de wens van patiënte om thuis verder begeleid en behandeld te worden. Door de diëtiste van het verpleeghuis wordt, in nauwe samenwerking met de huisarts, begeleiding geboden bij het volgen van een dieet, gericht op suppletie van voedingsdeficiënties en op reductie van het overgewicht. De ergotherapeute maakt een plan voor huisaanpassingen ter preventie van valpartijen en voor een alarmsysteem voor noodsituaties. Elf dagen na opname in het verpleeghuis gaat patiënte naar huis en na 2 maanden is zij goed hersteld. Haar gewicht is verminderd tot $76 \mathrm{~kg}$ de foliumzuurconcentratie heeft weer normale waarden bereikt en zij is weer goed mobiel, met behulp van een looprek.

Commentaar. Deze ziektegeschiedenis illustreert dat er na een val bij ouderen - ook zonder fracturen - aanzienlijke invaliditeit ten aanzien van ADL en mobiliteit kan optreden, met belangrijke consequenties voor het zelfstandig functioneren thuis. Het sociale netwerk kan ontoereikend blijken, terwijl er ook geen indicatie voor een ziekenhuisopname wordt gezien. De uit nood gekozen oplossing om deze patiënte tijdelijk in een verpleeghuis op te nemen, blijkt echter ook gericht geïndiceerd te zijn, zoals voor revalidatie, observatie en diagnostiek op verpleeghuisniveau (lichamelijk, psychisch, maar ook sociaal) en voor tijdelijke ondersteuning van het sociale netwerk door advisering, begeleiding en het realiseren van huisaanpassingen. De uit nood geboren verpleeghuisopname impliceerde dus veel meer dan alleen passief herstellen, en resulteerde in ontslag naar een zodanige situatie, dat pariënte zich weer gelukkig en veilig in haar eigen omgeving kon voelen. Maar ook zonder ontslag kan verpleeghuiszorg tot resultaten leiden, die ondanks de nood en de ernst van de situatie als positief ervaren worden. Optimale benutting van de verschillende verpleeghuisfuncties (binnen en buiten de muren van het verpleeghuis), een probleemgerichte aanpak in multidisciplinair teamverband en overleg tussen zorgverleners onderling en tussen zorgverleners, patiënt en diens familie dragen bij tot een positief resultaat van de geboden zorg.

Patiënt $\mathrm{B}$, een man van 61 jaar, lijdt aan de chorea van Huntington. Al jaren is hij onder behandeling en controle van de neuroloog. Sinds 1985 is hij in dagbehandeling van het verpleeghuis. In. regelmatige samenspraak met de huisarts, de netiroloog, de verpleeghiuisarts en de verpleegkundige van het dagbehandelingsteam hebben de echigenore en zijn kinderen steeds tegemoet kunnen komen aan de uitdrukkelijke wens van patiënt om zo lang mogelijk thuis te blijven. Geleidelijk echter is zijn toestand achteruitgegaan. In 1989 wordt hij rolstoelafhankelijk, de communicatie wordt moeilijker en de ADL-functies verslechteren. Hij krijgt steeds vaker verslikpneumonieën. Actief deelnemen aan wat er om hem heen gebeurt, kan hij niet meer. Opname in het verpleeghuis wordt door de familie voorlopig nog van de hand gewezen. Omdat er nog geen andere geschikte woning voor patiënt beschikbaar is, worden door de ergotherapeute van de dagbehandeling woonaanpassingen gerealiseerd. Na uitbreiding van de dagbehandelingsfrequentie en na de afspraak met patiënt om bij calamiteiten een beroep te doen op het verplecghuis ontstaat een acceptabel, nieuw evenwicht. De huisarts schakelt enkele malen de verpleeghuisarts in voor advies en begeleiding in de thuissituatie. 
In 1991 wordt een woning gevonden die het mogelijk maakt dat patiënt met zijn vrouw in de eigen omgeving kan blijven, met 5 dagen per week dagbehandeling in het verpleeghuis. De belastbaarheid van de familie wordt desalniettemin zwaar op de proef gesteld. Met medicatie in de vorm van levomepromazine $25 \mathrm{mg} 4 \mathrm{dd}$ en haloperidol 5 mg 2 dd en met 4 maal per jaar een korte, tijdelijke opname in het verplecghuis is de zorgverlening thuis nog vol te houden. De verslikpneumonieën treden echter steeds frequenter op. De onafwendbare teruggang, door het reeds lang bestaande ziekteproces drukt uiteindelijk toch te zwaar op het uithoudingsvermogen van de naaste omgeving. De mogelijkheden van een aanleunwoning bij een verzorgingstehuis of van groepsverzorging komen niet meer in aanmerking. Patiënt is niet meer in staat zelfstandig beslissingen te nemen. Berustend in het onvermijdelijke besluit de familie in januari 1993 tot opname in een verpleeghuis. Familie en hulpverleners beseffen dat de laatste fase is aangebroken, die helaas niet in de door de patiënt zo gewenste omgeving kan plaatsvinden, maar in een andere, minder vertrouwde situatic.

De eerste maanden na de opname lijkt patiènt door alle afleiding, de contacten met andere patiënten en de continue aanwezigheid van ziekenverzorgenden wat levendiger te zijn geworden. Deze relatieve verbetering bevestigt voor de familieleden dat zij met de verpleeghuisopname een juiste beslissing hebben genomen. Meer uitgerust dan voorheen bezoeken zij nu dagelijks bij toerbeurt de patiënt in zijn kamer of in de huiskamer. Het onafwendbare verloop van de ziekte en de noodzaak van de opname worden minder negatief beleefd door de invulling die men er onder de gegeven omstandigheden aan heeft kunnen geven. Commentaar. Dit voorbeeld toont dat verpleeghuiszorg - hier in de vorm van dagbehandeling en consultatie - al ver vóór een uireindelijke opname aangewend kan worden om een zo lang mogelijk verblijf thuis te bevorderen. Bovendien kunnen tijdelijke opnamen en een beroep op het verpleeghuis in geval van nood de draagkracht van de omgeving vergroten. Tezamen met een gecoördineerde takkerdeling van zorgverleners en een doelmatige communicatie met de betrokken familie kan zo beter op de wensen van patiënt en familie worden ingespeeld. Ook vergemakkelijkt een dergelijk zorgbeleid de acceptatie van uiteindelijk soms onvermijdelijke beslissingen.

Patiënt $\mathrm{C}$ is een vrouw die sinds haar $80 \mathrm{e}$ jaar verblijft in een verzorgingstehuis, inmiddels 5 jaar. Zij is nog redelijk zelfstandig, maar loopt onzeker en zegt snel moe en wisselend duizelig te zijn. Vet eten verdraagt zij niet. In het verleden heeft zij een galblaasoperatie en een operatie voor een verzakking ondergaan. Volgens de verpleegkundige is er de laatste tijd sprake van geheugenstoornissen en achterdocht.

In het verzorgingstehuis weet men niet goed raad met haar. Wat zou gedaan moeten worden: betere aanpassingen in haar kamer, meer zorg, andere medicatie, overplaatsing naar een verpleeghuis, verwijzing naar een ziekenhuis? De huisarts roept de verpleeghuisarts in consult. $\mathrm{Na}$ lichamelijk en psychisch onderzoek en na laboratoriumonderzoek luidt het advies: groepsverzorging geven in het verzorgingstehuis in het kader van het substitutieproject, dag-nachtritme structureren, andere medicatie geven (neurolepticum in een lage dosering), patiënt op dementie onderzoeken volgens een afgesproken protocol, consult van een psychiater regelen, aangepaste schoenen en steunkousen aanmeten (via de 
consulentrevalidatiearts van het verpleeghuis is dit mogelijk) en pariënt voorlopig niet opnemen in het verpleeghuis.

De groepsverzorging geeft lange tijd goed resultaat, maar na 2 jaar komen geleidelijk toch ook andere problemen naar voren: patiënte krijgt zwerfneigingen en vertoont emotionele labiliteit, die met een toenemende paranoïdie niet goed meer op te vangen is. Vooral 's avonds en 's nachts, alleen op haar kamer, is zij erg onrustig en angstig. Als gevolg van deze onrust en het secundaire slaaptekort ontstaat oververmoeidheid, waardoor de groepsverzorging mislukt. In overleg met de staf van het verzorgingstehuis, de familie en de verpleeghuisarts stelt de huisarts aan patiënte voor zich voor een maand te laten opnemen in het verpleeghuis. Gelaten stemt zij met het voorstel in en wordt op de psychogeriatrische afdeling van het verpleeghuis opgenomen. Het multidisciplinaire behandelplan bestaat onder meer uit: algemeen lichamelijk en neuropsychologisch onderzoek, routine-laboratoriumonderzoek bij opname, inventarisatie en verbetering van ADL-functies, observatie van gedrag en leefpatroon zoals voeding, defecatie- en mictiegewoonten, communicatiemogelijkheden, observatie van belangstelling en activiteitenniveau (onder andere via de activiteitenbegeleiding) en bewaking van het slaap-waakpatroon. Er wordt gekozen voor een gestructureerde benadering met nabootsing van de groepsverzorgingsactiviteiten, het scheppen van een rustige sfeer en aandacht voor het gedrag bij alleen zijn en het slapen op een éénpersoonskamer. Fysiotherapeut, ergotherapeut en diëtiste participeren in het behandelprogramma. Ruim anderhalve maand na opname heeft patiënte haar oorspronkeljike ritme terug en kan zij tengkeren naar het substirurieproject in 24 het verzorgingstehuis, waar de groepsverzorging weer kan worden voortgezet. Zowel zijzelf als haar omgeving beoordeelt de huidige situatie als positief.

Commentaar. De gezondheidsproblemen van deze patiënt leren dat een projectmatige zorgaanpak met consultatie, tijdelijke opname en gestructureerde verpleeghuiszorg in de eigen omgeving van de patiënt (substitutie), in combinatie met inzicht in de mogelijkheden en onmogelijkheden van de respectieve zorgvoorzieningen, een bijdrage leveren aan een flexibel zorgsysteem en het uitstellen of voorkómen van een verpleeghuisopname. Met een dergelijke zorg kan bovendien ingespeeld worden op de (principiële) wens zo lang mogelijk in de eigen omgeving te kunnen blijven wonen. Inmiddels maken veel lichamelijk en psychogeriatrisch gehandicapte patiènten gebruik van de substitutie van verpleeghuiszorg in verzorgingstehuizen.

Verpleeghuiszorg is veel meer dan het stereotiepe beeld dat sommigen ervan hebben. Behalve voor langdurige, multidisciplinaire zorg $(51 \%$ van alle nieuwe opnamen) en terminale zorg (3\%) komen veel patiënten voor revalidatie (39\% van alle nieuwe opnamen, doch $53 \%$ indien men alleen de somatische patiënten in beschouwing neemt). ${ }^{2}$ Ook komt een toenemend aantal patiënten voor de minder bekende functies als tijdelijke opvang, crisisopvang, kortdurende observatie en diagnostiek en speciale verpleging (onder andere comapariënten en patiënten met continue ambulante peritoneale dialyse).

Tijdelijke opvang betreft meestal opnamen voor enkele weken ter ontlasting van het thuismilieu, zodat de verzorgende partner met vakantie kan of tijdelijk afwezig kan zijn in geval van bijvoorbeeld een ziekenhuisopname. Met deze tijdelijke verpleeghuisopnamen ondersteunt het verpleeghuis dus indirect de thuiszorg. 
Jaarlijks worden ruim 35.000 nieuwe patiènten in de verpleeghuizen opgenomen en komen meer dan 9000 patiënten in dagbehandeling van verplecghuizen. Daarnaast verblijven nog eens ruim 8000 patiënten in verplecghuissubstitutieprojecten, hoofdzakelijk meerzorg-en groepsverzorgingsprojecten in verzorgingstehuizen. Verplecghuisopnamen vinden zowel vanuit het ziekenhuis plaats (somatische $64 \%$ en psychogeriatrische ruim 20\%) als vanuit de thuissituatic en het verzorgingstehuis (somatische 36\% en psychogeriatrische ongeveer $75 \%$ ). Het verzorgingstehuis is vooral plaats van herkomst bij psychogeriatrische patiënten ( $23 \%$ van de psychogeriatrische verpleeghuisopnamen). Lang niet alle verplecghuisopnamen zijn permanent: 1 op de 3 patiênten kan uiteindelijk na behandeling en revalidatie naar huis of verzorgingstehuis worden ontslagen.

Dames en Heren, iedere verpleeghuisopname is voor de patiènt en voor diens omgeving een ingrijpende gebeurtenis, zeker als de prognose van de gezondheidstoestand een blijvende opname waarschijnlijk maakt. Tegenzin in opname is begrijpelijk, omdat de patiënt zijn vertrouwde omgeving moet verlaten. Hoewel opname soms vanuit de sociale situatic als noodoplossing wordt gekozen, blijkt vrijwel altijd een complex van factoren een rol te spelen: ingewikkelde en meervoudige pathologische afwijkingen (chronische ziekten, comorbiditeit, recentelijk doorgemaakte acute aandoeningen), een hoge mate van invaliditeit en niet zelden de aanwezigheid van stemmings- en gedragsstoornissen." Deze gezondheidsproblemen maken continue verpleegkundige, (para)medische en psychosociale zorg nodig. Met deze multidisciplinaire zorgverlening wordt gestreefd naar een nieuw bestaansevenwicht met een zo hoog mogelijk niveau van zelfredzaamheid, ondanks beperkingen en handicaps en ondanks een voor sommigen progressief verminderend levensperspectief. Wat in eerste instantie een noodoplossing lijkt, wordt, waar mogelijk, tot een deugdelijk resultaat gevoerd door gerichte, multidisciplinaire behandeling, verpleging en begeleiding. 


\section{LITERATUUR}

1. Oostvoged FJG. De historische onswikkeling van her verplecghuis, In: Trommel J, Ribbe MW, Stoop JA, red. Capita selecta van de verpleeghuigenecskunde. Utreche Bohn, Scheltema \& Holkema, 1989; 3-20.

2. SIVIS, Jarbock verpleqghuizen 1992 . Utreche Stichting Informatiecentum voor de Gezondheidszorg (SIG), 1993.

3. Bakker-Winnubar M. Het verplecghuis. In: Schouten J. Leering C. Bender J, red. Leerboek geriatrie. Utrecht: Bohn, Scheltema \& Holkema. 1989: 240-8.

4. Schols JMGA, Wierik MJM re. Verplecghuiszorg buiten de muten: dagbehandeling, consultatic en substitutieprojecten. Ned Tijdschr Geneeskd 1993; 137: 2717-22.

5. Ziekenfondsrad. Subsidichesluit substitutie verplecghuiszorg. Amstelveen: Ziekenfondsrad, 1988.

6. Ziekenfonderaad. Subidiering substirutie verplecghuisworg 1993. SGZ/23837. Amstelveen: Zickenfondsraad. 1992.

7. Nederlandse Vereniging voor Verplecghuizorg (NVVz). Notais Zorg op maat. Verplecghuizen op de zorgmarkr. Nr 592.004 Utreche Nederlande Zorgfederatic, 1992.

8. Wierik MJM te, Frederiks CMA, Visser APh, Sturmans E Verplecghuisopname: een onderzoek bij op te nemen ouderen. Tijdachr Gerontol Geriatr 1991; 22: 209-15.

9. Ribbe MW, Frijten DHM, Mens JTh van. Kenmerken van verplecghuispatienten bij eerste opnames lecfijj. gealacht en morbiditeit. Ner Tijdachr Geneeskd 1993; 137: 2544-8. 


\title{
VERPLEEGHUISZORG BUITEN DE MUREN: DAGBEHANDELING, CONSULTATIE EN SUBSTITUTIEPROJECTEN
}

\author{
J.M.G.A. Schols en M.J.M. te Wierik
}




\section{SAMENVATIING}

De Nederlandse verpleeghuissector heeft, sinds het van kracht worden van de Algemene Wet Bijzondere Ziektekosten (AWBZ) in 1968 een sterke groei doorgemaakt. In de afgelopen jaren is ook de verpleeghuiszorg buiten de muren van het verpleeghuis tot ontwikkeling gekomen.

In dit artikel wordt, na een algemene beschouwing over verpleeghuiszorg en kenmerken van verpleeghuispatiënten in relatie tot zowel opname als resultaat van de opname, nader ingegaan op de semi- en extramurale zorgmogelijkheden van het hedendaagse verpleeghuis.

\section{SUMMARY}

Outreaching nursing home care: ambulatory day-care, consultation and substitute care projects

The nursing home sector in the Netherlands has developed strongly since treatment and nursing in these institutions are borne by the Exceptional Medical Expenses Compensation Act (AWBZ, 1968). In the past few years nursing home outreaching care also has developed progressively.

In this article the various possibilities for so called substitute care by nursing homes are presented and discussed. 


\section{INLEIDING}

De Nederlandse verpleeghuissector heeft, sinds het van kracht worden van de Algemene Wet Bijzondere Ziektekosten (AWBZ) in 1968, een sterke groci doorgemaakt. Kwantitatief is er bijna een vendubbeling van de toenmalige verpleeghuiscapaciteit opgetreden. Op dit moment zijn er in Nederland 333 verpleeghuizen met in totaal circa 52.000 bedden en circa 3300 dagbehandelingsplaatsen. ${ }^{-4}$

Ook kwalitatief is er sinds 1968 veel veranderd. Van gestichten waar chronische (vooral verpleegkundige) zorg voor uitbehandelde ziekenhuispatiënten werd geboden, zijn de verplecghuizen gezondheidszorginstellingen geworden waar behandeling, begeleiding, verpleging en verzorging worden geboden aan patiènten met een complexe zorgbehoefte, die dan ook in de regel continue, langdurige, systematische en multidisciplinaire zorg (CLSM-zorg) nodig hebben. Het hedendaagse verpleeghuis kent de volgende functies: revalidatie/reactivering, langdurige zorg (behandeling, begeleiding, verpleging en verzorging), terminale zorg. observatie en diagnostiek, consultatie en advies, tijdelijke opvang en crisisopvang. Afhankelijk van de aard en de omvang van de hulpvraag worden deze functies zowel intramuraal, semimuraal (dagbehandeling) als extramuraal tocgepast."

In de laatste jaren is verpleeghuiszorg buiten de muren van het verpleeghuis tot ontwikkeling gekomen. De vergrijzing en de daaraan gekoppelde toename van de zorgbehoefte doet immers de vraag naar zorg alsmaar toenemen. Door de bezuinigingen in de gezondheidszorg zijn dan ook knelpunten ontstaan. Zo zouden meer psychogeriatrische patiënten opgenomen moeten worden dan de huidige opnamecapaciteit van verpleeghuizen toelaat. Bovendien is te verwachten dat de groei in capaciteit in de toekomst achter zal blijven bij de vraag. In het toekomstige gezondheidszorgbeleid wordt immers substitutic van zorg - van gecompliceerd en duur (opname in gespecialiseerde instellingen van de tweede lijn) naar eenvoudig en goedkoop (rondom de thuissituatie en in dagbehandeling) - centraal gesteld om zodoende meer zorgbehoevende mensen te bereiken alsook om daarmee een (relatieve) kostenreductie te realiseren. Substitutie van zorgfuncties voor ouderen zal voorts moeten leiden tot een versterking van de thuiszorg, waarmee tevens tegemoet gekomen wordt aan de wens van veel ouderen om zo lang mogelijk thuis of in het verzorgingstehuis te kunnen blijven wonen.

De verpleeghuizen trachten in te spelen op deze ontwikkelingen door ondersteuning van de zorg buiten de eigen muren aan te bieden. Zowel voor artsen werkzaam in het intramurale als voor artsen werkzaam in het extramurale veld is inzicht in deze zorgondersteuning van belang voor (vroegrijdig) ontslag van pariënten uit ziekenhuizen, het voorkómen van (versnelde) achteruitgang en het voorkómen of uitstellen van opname in verpleeghuizen.

In dit artikel wordt, na een algemene beschouwing over verplẹghuiszorg en kenmerken van verpleeghuispatiènten in relatie tot zowel opname als resultaat van de opname, nader ingegaan op de semi- en extramurale zorgmogelijkheden van het hedendaagse verplecghuis. Eveneens wordt gepoogd een antwoord te geven op de vraag of de externe verplecghuisactiviteiten daadwerkelijk soelaas kunnen bieden voor de alsmaar groeiende problematiek van zorgbehoevende ouderen die geen plaats in het verpleeghuis zelf kunnen vinden. 


\section{OPNAME IN HET VERPLEEGHUIS}

Ook al zijn verpleeghuizen niet exclusief voor hen bedoeld, getalsmatig vormen ouderen toch de belangrijkste doelgroep van het verpleeghuis. Binnen de verpleeghuissector is dan ook deskundigheid ontwikkeld op het terrein van de behandeling, de verpleging en de begeleiding van ouderen. Kenmerk van het zorgconcept is dat, in samenspraak met patiënt en (of) familieleden op multidisciplinaire wijze tot een geïntegreerde patiëntenzorg wordt gekomen. Een systematische opzet van de voorbereiding, planning, uitvoering en evaluatie van de zorgverlening is daarbij noodzakelijk.

Kenmerkend bij de oudere zorgvrager is, in het algemeen dat, ten gevolge van organische aandoeningen functiestoornissen optreden die het zelfstandig functioneren bedreigen. Gezien de complexe problemen dient de hulpvraag geinterpreteerd te worden in relatie tot de persoonlijke leefwereld van de patiënt en moet de professionele hulpverlening in verpleeghuizen vooral probleemgericht en niet uitsluitend ziektegericht zijn. Het zorgconcept kent daarbij 'cure'- en 'care'-aspecten, waarbij de gezondheidsproblemen en de prognose bepalen of de zorg meer 'cure' dan wel 'care' betreft. Vanwege de prognose van de betreffende aandoeningen geldt de zorgverlening, behalve de behandeling van intercurrente ziekten en de multidisciplinaire revalidatie, vaak ook de begeleiding van patiënten bij het adaptatieproces ten aanzien van hun handicaps.'

Uitgangspunt zal steeds een individueel zorgplan zijn waarin - uitgaande van de mogelijkheden van de patiënt - de specifieke bijdragen van de verschillende hulpverleners en de ondersteunende activiteiten van de verwanten zijn opgenomen. De verpleeghuisarts geeft inhoudelijke sturing aan de zorgverlening. Onder zijn leiding werken, behalve verplegenden voor de basiszorg, verschillende therapeuten samen voor de individueel gerichte, integrale zorgverlening: fysiotherapeuten, logopedisten, ergotherapeuten, maatschappelijk. werkenden, psychologen, activiteitenbegeleiders en diëtisten. Deze multidisciplinaire werkwijze kenmerkt de zorgverlening in het verpleeghuis."

Voor het streven naar substitutie van verpleeghuiszorg is het van belang te weten welke patiëntgebonden factoren het resultaat van een opname bepalen, te meer daar het verpleeghuis voor een deel van de patiënten de laatste schakel is in het voorzieningenpakket voor ouderen. Te Wierik et al. onderzochten kenmerken van op te nemen. verpleeghuispatiënten en gingen na of deze verschilden met betrekking tot het doel van de opname (reactivering versus permanente opname) en de herkomst van de patiënt (eigen omgeving inclusief verzorgingstehuis versus ziekenhuis). ${ }^{6}$ Het betrof hier een onderzoek in de regio Maastricht bij 157 op te nemen verpleeghuispatiënten, die bij opname zeker zo hulpbehoevend waren als verpleeghuispatiënten in het algemeen.

Bij ruim de helft van de patiènten (54\%) was het doel van de opname het permanent ondersteunen van een aantal levensfuncties; $35 \%$ van de patiènten werd opgenomen om gereactiveerd te worden. Deze getallen komen ongeveer overeen met landelijke cijfers.' Binnen de heterogene groep op te nemen patiënten zijn 4 subgroepen te onderscheiden (tabel 1). Deze groepen verschilden niet of nauwelijks inzake de achtergrondkenmerken leeftijd, geslacht en burgerlijke staat, de hulpbehoefte en her sociale netwerk. Wel bestonden er duidelijke verschillen in de aard van de aandoeningen, de woonsituatie en het gebruik van eerstelijns professionele zorg. 
woonsituatie:

- huis niet getijkvloers

- huis gelijkvioers

- bejaarden-/aanleunwoning

- verzorgingstehuis

- anders

gebruik von professionele zorg:

- geen professionele zorg

- wijk- of gezinszorg

- wijk- en gezinszorg

- verzorgingstehuis

hoofddiognose:

- psychische stoornissen*

- somatische hoofddiagnosen

- hart-vaatstelsel (met name CVA)

- ongevalsletsels

- nieuwvormingen

- aanvullende classificatief

- zenuwstelsel/zintuigen

- bewegingsstelsel

- overig

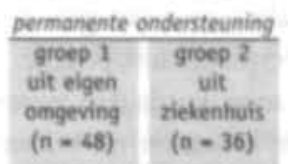

7 (15)

2 (4)

25 (52)

1 (2)

\section{1 (2)}

14 (29)

$8(17)$

25 (52)

$16(44)$

9 (25)

2 (6)

9 (25)

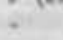

18 (53)

\begin{tabular}{ll}
$3 \quad(9)$ \\
\hline
\end{tabular}

4 (12)

9 (26)

33 (69)

15 (31)

5 (10)

1 (2)

3 (6)

4 (8)

$+$

2 (4)
$18(50)$

18 (50)

13 (36)

(3)

3 (8)

\begin{tabular}{|c|c|}
\hline \multicolumn{2}{|c|}{ recthering } \\
\hline $\begin{array}{l}\text { groep } 3 \\
\text { uit eigen } \\
\text { omgeving } \\
(n-20)\end{array}$ & $\begin{array}{c}\text { groep } 4 \\
\text { vit } \\
\text { giekenhuis } \\
(n-35)\end{array}$ \\
\hline $14(70)$ & $21(60)$ \\
\hline $2(10)$ & 7 (20) \\
\hline 1 (5) & 4. (11) \\
\hline 3 (15) & 3 (9) \\
\hline$=$ & * \\
\hline $4(20)$ & 17 (48) \\
\hline B (40) & $14(40)$ \\
\hline $5(25)$ & 1 (3) \\
\hline 3 (15) & 3 (9) \\
\hline $2(10)$ & . \\
\hline $18(90)$ & $35(100)$ \\
\hline 3 (15) & $15 \quad(43)$ \\
\hline 3 (15) & 8 (23) \\
\hline 3 (15) & 1 (3) \\
\hline $2(10)$ & 5 (14) \\
\hline $1 \quad(5)$ & 1 (3) \\
\hline 3 (15) & 2 (6) \\
\hline 3. (15) & 3 (9) \\
\hline
\end{tabular}

- Meestal dementie.

$\uparrow$ Tot deze categorie aandoeningen behoren onder meer: eerdere heupoperatie, amputatie of andere operatie/orthopedische ingreep.

De kenmerken van de groep ouderen die vanuit de eigen omgeving definitief werd opgenomen, geven aan dat door chronisch-progressieve aandoeningen de hulpbehoefte dermate groot is geworden dat, ondanks de aanwezige professionele zorg, langer verblijf in de eigen omgeving of in het verzorgingstehuis niet meer mogehijk was. Bij de groep ouderen die vanuit het ziekenhuis definitief in het verpleeghuis werd opgenomen, wijzen de kenmerken in de richting van een zodanige verslechtering van de gezondheidstoestand, dat een ziekenhuisopname en vervolgens verpleeghuisopname noodzakelijk was. De prognose ten aanzien van de gezondheidstoestand bepaalt bij deze groep het doel van de opname.

Bij de patiënten die vanuit de eigen omgeving ter reactivering werden opgenomen, lijkt de verpleeghuisopname het vervolg op een langer durend proces, waarbij de aard en de prognose van de onderliggende ziekten functieverbetering niet uitsloten. Bij de reactiveringspatiënten, afkomstig uit het ziekenhuis lijken vooral de gevolgen van ernstige acute aandoeningen, zoals een cerebrovasculair accident of een traumaletsel, de bepalende factoren voor de verplecghuisopname te zijn. ${ }^{\omega}$ Door dezelfde patiënten tot 1 jaar na hun opname te volgen kon tevens onderzocht worden welke opnamekenmerken samenhangen met het resultaat van de verpleeghuisopnamen. Van deze groep was na 1 jaar $15 \%$ ontslagen naar huis of naar een verzorgingstehuis, terwijl $41 \%$ was overleden en $44 \%$ nog steeds was opgenomen. De functionele toestand bij opname bleek de belangrijkste determinant van het verpleegresultaat te zijn, maar ook het aantal diagnosen, de 
aard van de hoofddiagnose, de leeftijd, het geslacht en de belasting voor de verleners van de mantelzorg vóór de opname bleken een rol te spelen. De ouderen die bij opname het minst hulpbehoevend zijn, blijken de meeste kans te hebben om met een verbeterde validiteit ontslagen te worden. Dit legitimeert vooralsnog voor deze ouderen de verpleeghuisopname.

De doelgroep voor substitutie van zorg wordt dan gevormd door de ouderen die qua hulpbehoefte een russenpositie innemen en bij wie géén reactivering meer mogelijk is."

\section{SUBSTITUTIE VAN VERPLEEGHUISZORG}

Het doel van de voorgestelde substitutie van verpleeghuiszorg is om vanuit de tweede lijn, in casu het verpleeghuis, aan de eerste lijn en de verzorgingstehuizen handreikingen te bieden, waardoor deze langer in staat zijn om de zorg op zich te nemen. Achtereenvolgens bespreken wij de dagbehandeling, de consultatiefunctie en de substitutieprojecten.

\section{Dagbehandeling}

De ontwikkeling van dagbehandeling eind zeventiger jaren was in feite het eerste voorbeeld van substitutic. De officièle omschrijving van de indicatiestelling voor dagbehandeling luidt als volgt: 'Een indicatie voor dagbehandeling wordt geacht aanwezig te zijn, indien en zolang voor de verzekerde de verpleging, paramedische behandeling of geneeskundige behandeling in een verpleeginrichting gedurende de dag of een gedeelte daarvan redelijkerwijs zijn aangewezen om zich in het

32 eigen milieu te handhaven'.' Dagbehandeling zou daarmee moeten kunnen leiden tot vervroegd ontslag uit het ziekenhuis of verpleeghuis of tot uitstel of afstel van opname in een verpleeghuis. De semimurale dagbehandeling wordt zowel aan somatische als aan psychogeriatrische patiënten geboden, die daartoe een of meerdere malen per week het verpleeghuis bezoeken. In principe kan aan hen dezelfde zorg geboden worden als aan de opgenomen verpleeghuispatiënten (tabel 2).

Gedegen effectonderzoek met betrekking tot de dagbehandeling is in Nederland (nog) niet verricht. Nies bevestigt op basis van literatuuronderzoek de ontlasting van het zorgnetwerk thuis. ${ }^{10} \mathrm{Hij}$ is minder enthousiast over de therapeutische resultaten en het substitutie-effect van de dagbehandeling. Vervroegd ontslag uit het ziekenhuis of het verpleeghuis door dagbehandeling blijkt maar zeer beperkt voor te komen, en slechts bij een deel van de somatische patiënten wordt opname vermeden. Uitstel van de verpleeghuisopname komt bij een beperkt deel van de somatische/psychogeriatrische patiënten met verpleeghuisindicatie voor. Uit zijn analyse blijkt tevens dat de dagbehandeling deels een nieuwe (lichtere) categorie patiënten heeft aangetrokken. Niettemin blijkt dagbehandeling een zeer waardevolle en erg gewaardeerde voorziening te zijn, zowel voor patiënten en personen uit hun naaste omgeving als voor professionele hulpverleners thuis. ${ }^{10}$

Mede door de ontwikkeling van dagbehandeling zijn de verpleeghuizen geleidelijk een bredere maatschappelijke functie gaan vervullen.

\section{Consultatie}

In 1987 werd de consultatiefunctie van verpleeghuizen operationeel. "Door een wijziging van het Besluit Verpleging in Verpleeginrichtingen Bijzondere Ziekte- 
TABEL 2

Kenmerken van

alternatieven voor intramurale verpleeghuiszorg. ter ondersteuning van de eerstelijnsaorg en

van de zorg in verzorgingstehuizen officieel ontstaan: omvang:

financièn: plasts:

doelen:

indicatiestelling:

zorgaanbod:

verantwoordelijkheid:

evaluatie:

officieel ontstaan:

omvang:

financiên:

plaats:

doelen:

indicatiestelling:

zorgaanbod:

verantwoordetijkheid:

evaluatie:

officieel ontstaan:

omvang:

financièn:

plaats:

doelen:

indicatiestelling: zorgaanbod:

verantwoordelijkheid:

evaluatie:
1977

in 1993 circa 3300 plaatsen somatiek plus psychogeriatrie: 9000 nieuwe patiênten per jaar

AWB2

in verpleeghuis

vervoegd ontslag uit ziekenhuis of verpleeghuis uitstel of afstel van veipleeghuisopname

patient zo lang mogelijk handhaven in eigen omgeving ontlasting van mantelrorg

indicatiecominissie

ambulante verpleeghuiszorg met het totale multidisciplinaire zorgaanbod (revalidatiebehandeling, verpleging, psychosociale begeleiding etcetera) gedurende de dag of een deet ervan

verpleeghuisarts verantwoordelijk voor dagbehandeling.

huisarts blift medisch eindverantwoordelijk

wetenschappetijk effectonderzoek ontbreekt

\section{7}

per verpleeghuis wisselend qua intensiteit ingevuld

budgetverniming verpleeghuizen, boven de normale verpleegprijs

(AWBZ)

thuis of in verzorgingstehuis; poliktinisch in verpleeghuis.

patiènt 20 lang mogelijk handhaven in eigen omgeving

ondersteuning eerste lijn, verzorgingstehuis en mantelzorg

gèèn indicatiecommissie: consultatie op verzoek

gerichte eenmalige advisering van eerste lijn en verzorgingstehuis.

Mogelijkheid tot eenmalige screening. (Met name activiteiten van

verpleeghuisarts en ergotherapeut.)

verpleeghuis verantwoordelijk voor advisering wetenschappetijk effectonderzoek ontbreekt

1988

eind 1989: 88 projecten met circa 1496 patienten:

in 1993: 490 projecten met circa 8400 patiënten

diverse subsidiestromen ex art. 2 AWBZ: budgettair neutraal/2-4\%

vrijemargeregeling/gesubsidieerd èn Regeling Zwevende Bedden (WVC)

op projectlocatie met name in verzorgingstehuizen ( $86 \%)$

zo lang mogelijk handhaven van verpleeghuisgeindiceerden thuis of in verzorgingstehuis

bereiken van uitstel of afstel verpleeghuisopname

ondersteuning van zorg thuis of in verzorgingstehuis

indicatiecommissie

per project structurele multidisciplinaire inbreng:

aard projecten $(\%)$ :

meerzorg in verzorgingstehuizen (13\%)

groepsverzorging in verzorgingstehuizen $(52 \%)$

thuiszorg (3\%)

nachtopvang, noodbedden, aparte woonvormen $(11 \%)$

verpleeghuis verantwoordelijk voor geboden verpleeghuiszorg

huisarts blijft medisch eindverantwoordelijk, tenzij anders afgesproken

wetenschappelijk effectonderzoek ontbreekt

AWBZ = Algemene Wet Bijzondere Ziektekosten; WVC - ministerie voor Welzijn, Volksgezondheid en Cultuur (nu WWS). 
kostenverzekering bestaat sedertdien de mogelijkheid voor patiënten in de eerste lijn en in het verzorgingstehuis om de verpleeghuisarts of andere medewerkers van het verpleeghuis in consult te roepen. De verantwoordelijkheid voor de hulpverlening blijft bij de hulpverleners in de eerste lijn en (of) bij het verzorgingstehuis. Bij de advisering vanuit het verpleeghuis kan de totale deskundigheid ingezet worden, maar in de praktijk blijken vooral de verpleeghuisartsen en de ergotherapeuten ingeschakeld te worden (zie tabel 2). Bij consultatie kan het onder andere gaan om een eenmalige screening, om advisering terzake van hulpmiddelen voor de algemene dagelijkse levensverrichtingen (ADL) en terzake van woningaanpassingen, om medicatie- of dieetadviezen, om verpleegtechnische adviezen of om deskundigheidsbevordering via voorlichting en scholing. Uiteindelijk gaat het er ook hier om de betrokken patiènt zolang mogelijk thuis of in het verzorgingstehuis te handhaven met een zo hoog mogelijke mate van zelfredzaamheid. Wat het mogelijke substitutie-effect van de consultatiefunctie is, valt moeilijk te beoordelen. Inzicht in de concrete omvang, uitvoering en inhoud van deze functic ontbreekt, evenals wetenschappelijk effectonderzock ter zake.

\section{Substitutieprojecten.}

In 1988 werd het Subsidiebesluit Substitutie Verpleeghuiszorg goedgekeurd. ${ }^{\sharp}$ Op grond hiervan kan aan mensen met een verpleeghuisindicatie die op de wachtlijst staan en nog thuis of in het verzorgingstehuis verblijven extra ondersteuning vanuit het verpleeghuis geboden worden. De externe verpleeghuiszorg heeft daar-bij in de meeste gevallen een projectmatig karakter. De betrokken patiënten wordt additionele zorg geboden, die complementair is aan de mantelzorg en de eerstelijnszorg of de zorg in het verzorgingstehuis. Als voorwaarde voor substiturie geldt dat de zorg op minimaal hetzelfde niveau van kwaliteit verleend moet worden. ${ }^{19.14}$ Uiteraard kan de complementaire, externe verpleeghuiszorg alleen maar geboden worden in goede samenspraak met de al aanwezige eerstelijnshulpverlening of het verzorgingstehuis. Omdat bij substitutie de verpleeghuismedewerkers niẹ alleen adviseren, maar ook daadwerkelijk bij de behandeling en de verzorging betrokken kunnen zijn, dienen met de eerste lijn of met het verzorgingstehuis duidelijke afspraken gemaakt re worden betreffende de aard, de intensiteit en de verantwoordelijkheden met betrekking tot de zorgverlening. Zonder goede samenwerkings- en afstemmingsafspraken komt dit soort projecten niet of slechts moeizaam van de grond. "S Substitutieprojecten verpleeghuiszorg ontstaan meestal daar waar al wordt samengewerkt tussen verpleeghuizen en verzorgingstehuizen of andere eerstelijns-voorzieningen en niet: te vergeten de RIAGG's. Voorbeelden van substitutieprojecten verpleeghuiszorg worden aangegeven in tabel 2.

Tot op heden vinden de meeste projecten plaats in verzorgingstehuizen $(86 \%)$, die zich in de afgelopen decennia steeds meer van een woonvoorziening tot een zorgvoorziening voor ouderen hebben ontwikkeld. ${ }^{16}$ Het gegeven in het onderzoek van Te Wierik et al. dat van de patiënten die al dan niet na een ziekenhuisopname voor permanente ondersteuning werden opgenomen $40 \%$ in een verzorgingstehuis woonde, vormt hier dus duidelijk een aanknopingspunt voor substitutie." Gelet op de doelgroepen worden verzorgingstehuizen en verpleeghuizen vaak als de natuurlijkste partners beschouwd. Wat de zorgzwaarte in beide instellingen betreft, is er duidelijk sprake van een glijdende schaal met circa 15\% 
overlap, hetgeen overigens niet betekent dat het zorgpakket voor de overlappende groep identick is."

De toegenomen zorgzwaarte, de daarop kwalitatief en kwantitatief niet geềnte personele en materiële infrastructuur en de grenzen van de Wet op het Bejaardenoorden (WBO)-budget hebben de verzorgingstehuizen min of meer richting verpleeghuizen gedreven. Overal in den lande ziet men dan ook samenwerkingsverbanden ontstaan tussen verplecghuizen en naburige verzorgingstehuizen. Flexibilisering van verpleeghuiszorg door diverse subsidiestromen heeft substitutie van verplecghuiszorg naar verzorgingstehuizen tot gemeengoed gemaakt. Zo worden inmiddels, in substitutieverband, vele meerzorgprojecten (dat zijn projecten waarbij additionele (verpleeghuis)zorg wordt geboden, naast de aanwezige basiszorg) en groepsverzorgingsprojecten in verzorgingstehuizen uitgevoerd. Het substitutiebudget stelt zowel het verzorgingstehuis als het verpleeghuis in staat om de personele formatie uit te breiden en, indien noodzakelijk, bouwkundige aanpassingen te realiseren.

Voor elke patiënt in een substitutieproject dient een individuecl, integraal zorgplan uitgewerkt te worden, waarbij de inbreng van zowel het verzorgingstehuis, de eerste lijn (met name de huisarts) èn van het verpleeghuis duidelijk zijn aangegeven (figuur 1). " De bijdrage van het verpleeghuis heeft daarbij de functie van toegevoegde waarde, voortkomend uit ervaring met complexe zorg èn met een integrale, multidisciplinaire werkwijze. Tabel 3 geeft een overzicht van de bijdragen die een verpleeghuis verder kan bieden.

\section{FIGUUR 1}

Algemene opzet voor substitutie van yerpleeghuiszorg naar een verzorgingstehuis.

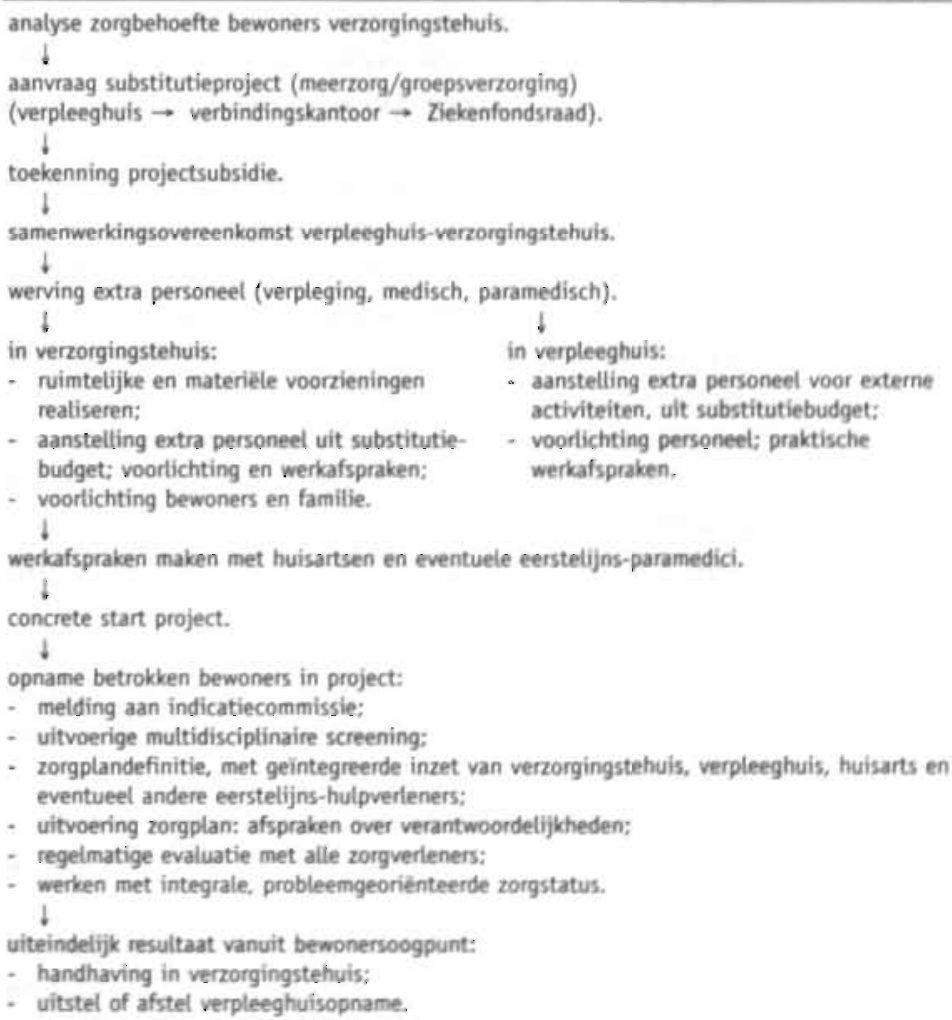


multidisciplinaire screening, zorgplandefinitie en advies ten aanzien van zorgorganisatie

advisering ten aanzien van nader ondenoek (laboratorium, specialisten, neuropsychologische diagnostiek)

overleg en zonodig adviezen over medicatie, voedingsproblemen, dieet, obstipatie, gedragsproblemen etcetera

advisering en uitvoering van fysiotherapeutische/ergotherapeutische/logopedische interventie

activiteiten in het kader 'ineer bewegen voor ouderen'

advisering ten aanzien van inschakelen orthopedisch instrumentmaker en schoenmaker

adviezen ten aanzien van zitcorrectie, zithouding, stoel- en rolstoelbeleid, begeleiding bij dagelijkse levensverrichtingen, andere aanpassingen en hulpmiddelen

- preventieadviezen met betrekking tot decubitus, beleid bij incidenten; gebruik van beschermende mastregelen (alarmering etcetera)

- adviezen met betrekking tot verpleegkundige handelingen waaronder wondverzorging, en over eventueel praktische bruikbare materialen

advisering ten aanzien van activiteitenplannen voor psychogeriatrische bewoners en het omgaan met patiênten met gestoorde contactfuncties

- deskundigheidsbervordering en nascholing (tiltechniek, zwachteltechniek, anti-decubitusbeleid,

hulpmiddelen etcetera)

\section{EFFECTONDERZOEK}

Op dit moment is er nog onvoldoende longitudinaal onderzoek gedaan naar de effecten van deze substitutieprojecten. Hoeksma en Mols geven vanuit een evaluatie-onderzoek aan, dat niet stringent wordt omgegaan met de voorwaarde dat de projectdechemers een verplecghuisindicatie moeten hebben (B.H. Hocksma, J.F.J.M. Mols, schriftelijke mededeling, 1990). Slechts 59\% van de projectpatiënten blijkt een dergelijke indicatie te hebben. Deze groep is qua zorgzwaarte min of meer vergelijkbaar met in verpleeghuizen opgenomen patiënten. Patiënten zonder indicatie hebben een duidelijk lichtere zorgzwaarte en zijn in feite vergelijkbaar met dagbehandelingspatiënten. Substitutie van verpleeghuiszorg lijkt hier dus een nieuwe patiëntencategorie aan te trekken, een fenomeen dat ook al werd genoemd bij de dagbehandeling. ${ }^{18}$

Verzorgingstehuisbewoners met nog maar lichte psychogeriatrische problemen blijken zeker baat te vinden bij een structurele zevendaagse opvang in een groepsverzorgingsproject." Praktijkervaringen doen vermoeden dat zeker ook enig soelaas wordt geboden aan bewoners met ernstige psychogeriatrische problemen. Dit geidt ook voor de service die in de individuele meerzorgprojecten aan zorgbehoevende somatische bewoners geboden wordt. Per saldo lijkt het hier echter meer om uitstel dan om afstel van de verpleeghuisopname te gaan. De ADL-hulpbehoefte van deze substitutiepatiēnten is immers vaak al zo groot, dat reeds vóór de start van de substitutie het maximale van de zorgverlening in het verzorgingstehuis geëist wordt. Overigens kan uitstel van opname ook als belangrijke winst gezien worden.

Wat betreft de substitutie van verpleeghuiszorg voor psychogeriatrische patiënten. die in de eigen omgeving wachten op permanente opname in een verpleeghuis, kan gesteld worden dat deze nog maar schoorvoetend van de grond komt. Op dit moment lopen er vanuit enkele verpleeghuizen experimenten met ondersteunde woonvormen voor vooral begeleidingsbehoevende psychogeriatrische patiënten. De doelgroep voor deze vorm van substiturie wordt geschat op circa $10 \%$ van de thuiswonende patiènten met een psychogeriatrische verpleeghuisindicatie." Substitutieprojecten voor somatische patiënten bij wie een indicatie bestaat om in de eigen omgeving, al dan niet via het ziekenhuis, permanente ondersteuning 
vanuit het verpleeghuis te krijgen (onderdeel van groep 1 en 2 in tabel 1) richten zich vooral op voortzetting van het verblijf thuis met aangepaste en adequate professionele zorg. Het betreft hier vooral experimenten, die beogen de samenwerking tussen verpleeghuis en eerste lijn te optimaliseren. ${ }^{3}$ Uit recent onderzoek is echter gebleken dat de hulpbehoefte van deze patiënten waarschijnlijk toch te groot is om een verplecghuisopname te voorkomen, te meer daar zij vaak al veel gebruik maken van professionele thuiszorg. De kwantiteit en de kwaliteit van de mantelzorg zal dan uiteindelijk, in complexe gezondheidssituaties, zoals deze (morbiditeit, invaliditeit en sociale omgeving), toch een zwaarwegende factor blijven bij de handhaving van de patiënt in de thuissituatie. Uitstel van verpleeghuisopname lijkt hiermee ook voor deze categorie patiënten dus het hoogst haalbare."

Dat bij het streven naar intensieve thuiszorg de substitutieprojecten verplecghuiszorg een extra impuls bieden aan de krachtenbundeling binnen de eerste lijn, verleent de projecten uiteraard een meerwaarde.

Gezien het bovenstaande en met het oog op de problematick van de zorgbehoevende ouderen, de samenwerking tussen eerste lijn en verpleeghuis èn het toekomstige zorgbeleid, is het van belang dat er goed opgezet onderzoek komt naar de mogelijkheden en effecten van de verplecghuiszorg buiten de muren. 


\section{LITERATUUR}

1. Ministerie van Welzijn. Volkagezondheid en Caltum. Financied overrichr zorg 1993. Den Haag: SDU, 1992.

2. Stichting Informatiecentrum voor de Gezondheidsorg (SIG). Sivis jaarbock verplocghuizen 1991. Utreche SIG. 1992.

3. Nationaal Ziekenhuis Instimux (NZ1), De intramurale gezondheidszorg in cijfers 1991, Utrecht: NZI, 1992.

A. Nederlandse Vereniging voor Verpleoghuiszorg. Verplecghuizen op de zorgmarks. Nr 592.004. Utreche NVVz, 1992.

5. Ribbe MW. Wegen in de verplenghuisgeneetkunde. Oratic. Amstendam: Vrije Universiteit, 1991.

6. Wierik MJM te, Frederiks CMA, Viser APh. Sturmans F. Verplecghuisopnames een onderzock bij op te nemen ouderen. Tijdache Gerontol Geriatr 1991: 22: 209-15.

7. Ribbe MW, Frijten DHM, Mens The van. Kenmerken van verplesghuispatienten bij exrste opname: lecftijd. geslacht en morbiditeit. Ned Tijdschr Geneeskd 1993; 137: 2544-8.

8. Wierik MJM te. Verplecghuisopname. Een ondernock nar factoren die van invloed zijn op verplecghuisopname en het verloop dasrvan. Proefschrift. Maasricht: Rijksuniversitcit Limburg, 1991.

9. Ziekenfondsraad (ZFR). Besluit daghehandeling in een verpleeginrichting dd. 29-6-1977 (art. 3, lid 2). Amstelveen: ZFR, 1978.

10. Nies HLGiR. Daghehandeling? Een tusientijdse balans van dagbehandeling in verplecghuinen. Tijdschr Gerontol Geriarr 1986; 17: 25-32.

11. Ziekenfonduad (ZFR), Consultatiove functie verplecginrichtingen. Amstelveen: ZFR, 1986: nr 320.

12. Zichenfondsrad (ZFR), Subsidiebeluit substinutie verplenghuiszorg. Amstedven: ZFR, 1988: ne 107.

13. Peters P, red. Innovatic in de zorgsector Jaarbock 1992/93. Den Haag: VUGA, 1992.

14. Ministerie van Welzijn, Volksgezondheid en Cultuur. Kwaliteit van zorg. Den Haag; SDU, 1991

15. Schols JMGA. Vanuit de praktijk, Substitutie verplecghuiszorg. Gegevens uit het streckverplecghuis Geertruidenberg. Vox Hospitii 1991; 15: 96-9.

16. Ziekenfondsrasd (ZFR). Subsidiëring substitutie verplecghuiszorg 1993. SGZ/23837. Amstelveen: ZFR. december 1992.

17. Nederlandse Vereniging voor Verplecghuiszorg, Strategische verkenningen. Discussienota over het strategische beleid van de NVV2 voor de komende 2 jaar. Utrecht NVV2, 1992.

18. Duine T], Peren HJM. Genormaliseend wonen - een incident? Een onderzock naar de omvang van de docigroep voot genormalisecrd wonen in verpleeghuizen en grocpsverzorgingsprojecten van verzorgingstehuizen. Tijdschr Gerontol Geriatr 1987; 18: 225-31. 


\title{
VERPLEEGHUISZORG IN BEWEGING; EEN INVENTARISEREND OVERZICHT VAN VIJF SUBSTITUTIEPROJECTEN VERPLEEGHUISZORG.
}

\author{
J.M.G.A. Schols, N.J.S. Theunissen, V. Borst en M.E. Sinnema
}




\section{SAMENVATTING}

Dit inventariserend onderzoek is verricht om inzicht te krijgen in het functioneren van vijf projecten substitutie verpleeghuiszorg in verzorgingshuizen, van Streekverpleeghuis St. Agnes (inmiddels de Riethorst) te Geertruidenberg. De hoofddoelstelling van substitutie van verpleeghuiszorg luidt: door adequate zorgverlening aan verpleeghuisgeïndiceerde verzorgingshuisbewoners uitstel of afstel van verpleeghuisopname realiseren. Door middel van interviews met 64 betrokkenen bij de projecten alsmede door het versturen van enquêtes zijn ervaringsgegevens verzameld. Van uitstel of afstel van verpleeghuisopname blijkt in een groot aantal gevallen sprake te zijn. In de periode 1991-1993 werden er van de 144 deelnemende verzorgingshuisbewoners slechts 11 alsnog in het verplecghuis opgenomen. Wat de feitelijke zorgverlening betreft, kan in de vijf projecten nog veel verbeterd worden. Het gaat daarbij vooral om langere openingstijden van de groepsverzorging, om een optimalisering van het methodisch werken alsmede om de realisering van een efficiënt multidisciplinair overleg. Van echte verplecghuiszorg is voorlopig nog geen sprake. Daarnaast blijkt de financiering van deze substitutieprojecten gecompliceerd en onzeker, omdat deze via verschillende kanalen verloopt en bovendien de continuïteit niet gewaarborgd is. Structurele zekerheid in dezen is alleszins geboden, ten behoeve van het beleid op langere termijn.

\section{SUMMARY}

\section{An inventory of 5 outreaching projects of the Geertruidenberg nursing home}

40 An inventory was made of 5 substitute care projects in old people's homes, performed by the nursing home in Geertruidenberg. Data were gathered by semi-structured interviews and inquiries. The general goal of substitution of nursing home care for outdoor patients is to provide complementary outreaching nursing home services, by which real nursing home admittance can be postponed or avoided. In fact, in many cases substitution care appears to avoid nursing home admittance. In 1991-1993 there were 144 participants in these projects, from which only 11 at last were admitted to the nursing home. In the near future however, the quality of these outreaching nursing home projects has to be improved, especially on aspects as: continuity and methodology of care and with respect tot the multidisciplinary approach. At last the financial support of these projects appears to be complicated and uncertain. A structural solution for this problem is urgent too. 


\section{INLEIDING}

De opnamecapaciteit van de Nederlandse verplecghuissector is nu én in de toekomst niet in staat om te voldoen aan de daadwerkelijke vraag.' De vergrijzing, de algemeen groeiende zorgbehoefte bij ouderen, die bovendien de zorgverlening liefst zo dicht mogelijk bij huis ontvangen en het overheidsbeleid hebben de ontwikeling van verplecghuiszorg buiten de muren sinds 1987 in een stroomversnelling gebracht. ${ }^{2}$ Op dit moment wordt in circa 500 substitutieprojecten complementaire verpleeghuiszorg geboden aan mensen met een verplecghuisindicatie, die nog thuis of in het verzorginghuis verblijven. De meeste projecten vinden vooralsnog plaats in verzorgingshuizen $(86 \%))^{3}$ De centrale doelstelling van substitutie van verpleeghuiszorg in het verzorgingshuis is om de aanwezige basiszorg aan te vullen met verpleeghuiszorg, waardoor aan verpleeghuisgeindiceerde bewoners een dermate adequate zorg geboden kan worden dat overplaarsing naar het verpleeghuis uitgesteld of voorkomen wordt. ${ }^{1-4}$ Er is nog weinig. longitudinaal effectonderzoek naar deze substitutieprojecten verricht. In diverse publicaties wordt wel melding gemaakt van goede voornemens en/of eerste praktijkervaringen of betreft het opinies van voor- en tegenstanders."-11

Te Wierik et al. vonden dat deelnemers van substitutieprojecten in zorgzwaarte overeenstemmen met recent in het verplecghuis opgenomen patiënten. De kwaliteit van zorg in verzorgingshuizen met een substitutieproject bleck weliswaar hoger dan in huizen zonder project, doch lager dan in verpleeghuizen. ${ }^{12}$

Vergelijking van projecten onderling was tenslotte bijna onmogelijk, aangezien de onderzochte projecten inhoudelijk en qua vorm vele verschillen vertoonden.

In dit artikel worden de resultaten weergegeven van een inventariserend onderzoek naar vijf substitutieprojecten in verzorgingshuizen, van Streekverpleeghuis St. Agnes te Geertruidenberg. De vraagstelling kan als volgt omschreven worden. Wat zijn de gevolgen van de substitutie voor de deelnemende bewoners, de verzorgingshuizen zelf én het verpleeghuis? Reeds eerder werd in algemene zin de opzet van deze projecten beschreven. ${ }^{10.11}$

\section{METHODE}

Het onderzoek werd uitgevoerd in de periode januari 1994 - juni 1994. Centraal stond het verzamelen en verwerken van ervaringsgegevens van direct betrokkenen bij deze projecten. Dataverzameling vond plaats door bestudering van afzonderlijke projectomschrijvingen, samenwerkingsovereenkomsten, verslagen van evaluarieve vergaderingen, schriftelijke enquêtering van 5 huisartsen, van de directies van de verzorgingshuizen (5) en het verpleeghuis en van 17 aselect gekozen bejaarden-/ziekenverzorgenden en aktiviteitenbegeleid(st)ers in de projecthuizen en van mondelinge interviews (gedeeltelijk aan de hand van semi-gestructureerde vragenlijsten per interviewgroep) afgenomen bij de directies (aanvullend), de hoofden verzorging van de 5 verzorgingshuizen, de 17 genoemde bejaarden-/ziekenverzorgenden en aktiviteitenbegeleid(st)ers (aanvullend), de aan de projecten participerende verpleeghuisartsen (2), de deelnemende paramedici (3 fysiotherapeuten, 1 ergotherapeute, 2 logopedistes, hoofd aktiviteitenbegeleiding), de verpleeghuispsychologe, een beleidsmedewerker van het verbindingskantoor AWBZ: 17 familieleden van 15 deelnemende bewoners en bij twee somatische meerzorgdeelnemers zelf. Betrouwbaar interviewen van deelnemende psychogeriatrische bewoners was niet haalbaar. Een respons van $100 \%$ werd nagestreefd en door de persoonlijke benadering bereikt. 


\section{RESULTATEN}

Alle deelnemers van de vijf Geertruidenbergse projecten hebben een officiële verpleeghuisindicatie, verstrekt via de regionale indicatiecommissie. Ze zijn daarvoor op de reguliere wijze gescreend door het verpleeghuisteam, als ware het een aanmelding voor verpleeghuisopname. In alle gevallen wordt specifiek gekeken naar de opvangmogelijkheden binnen het project versus de eventueel toch aanwezige noodzaak tot daadwerkelijke verpleeghuisopname. $85 \%$ van alle projectdeelnemers heeft een psychogeriatrische indicatie en neemt deel aan groepsverzorgingsactiviteiten; $15 \%$ heeft een somatische meerzorgindicatie.

Ten tijde van deelname wonen alle deelnemers in het verzorgingshuis; de grootste groep al geruime tijd. In enkele gevallen is sprake van nieuwe verzorgingshuisbewoners, ingestroomd onder de regionaal ingevoerde indicatie 'verzorgingshuis met substitutie'. Het betreft dan verpleeghuisgeïndiceerden, die nog lang geen uitzicht hebben op een verpleeghuisopname en aan wie opvang in een verzorgingshuis met substitutie meer soclaas biedt dan voortgezet verblijf thuis.

Tabel 1 geeft een overzicht van de patiëntenstroom in deze projecten in de jaren 1991-1993. In de 5 projecten is in deze jaren sprake van 144 verschillende substitutiepatiènten. 52 deelnemers overleden (36\%) en 11 werden alsnog opgenomen in het verpleeghuis $(8 \%)$, allen meer dan 1 jaar deelnemend in de projecten. Overplaatsing naar het verpleeghuis vindt plaats indien blijkt dat de substituriezorg geen soelaas meer biedt, als er een te grote 24-uurs zorgbehoefte ontstaat en/of hinderlijke gedragsstoornissen optreden. In de periode 1991-93 waren er 89 nieuwe deelnemers. Tabel 2 laat zien dat het aantal opnames uit de projecthuizen in de periode 1991-93 fors is afgenomen ten opzichte van de drie daaraan voorafgaande jaren, van in totaal 58 tot 23.

\section{Het zorgaanbod}

Substitutie-activiteiten in het kader van de individuele somatische meerzorg (aangeboden in twee van de vijf projeten) leiden, naast extra verpleegkundige ondersteuning, tot een regelmatige multidisciplinaire service vanuit het verpleeghuis. De medisch/paramedische inbreng zorgt ervoor dat vee! aandacht besteed wordt aan aspecten zoals: mobiliseren, blaastraining, decubituspreventie, goede zit- of lighouding, looprondes, ADL-training, adequate communicatie, adequaat verpleegkundig observeren, oordeelkundig medicatiegebruik etc. De deelnemende meerzorgbewoners en hun familieleden geven in de interviews aan blij te zijn.

\begin{tabular}{lrrrrr} 
& 1991 & 1992 & 1993 & 1994 & deeitotalen \\
\hline Start* & 55 & 67 & 68 & 81 & \\
Overteden & 14 & 16 & 22 & & 52 \\
Opname Agnes & 0 & 6 & 5 & 11 \\
Rest & 41 & 45 & 41 & 89
\end{tabular}

- Substitutiesubsidie wordt verstrekt voor een officieel goedgekeurd aantal deeinemers van 67 .

* In 1993 waren ef tijdelijk extra financiële middelen beschikbaar en konden meer deelnemers instromen.

TABEL 1

Deelnemersstromen in $1991 \mathrm{t} / \mathrm{m} 1993$ in de 5 substitutieprojecten van verpleeghuis St. Agnes te Geertruidenberg. 


\begin{tabular}{|c|c|c|c|c|c|c|c|}
\hline & 1988 & 1989 & 1990 & & $1991^{\circ}$ & $1992^{\circ}$ & $1993^{\circ}$ \\
\hline & & & & in project & 0 & 6 & 5 \\
\hline & & & & niet in project & 6 & 4 & 2 \\
\hline totaal & 18 & 20 & 20 & & 6 & 10 & 7 \\
\hline
\end{tabular}

- In de jaren 1991-1993 kan een onderscheid 'projectdeelnemer/niet projectdeelnemer' gemaakt worden.

met de toegevoegde substitutic-aandacht. Vanuit de verzorgingshuizen wordt de complementaire aandacht eveneens positief ervaren, zo blijkt uit de gevoerde gesprekken.

In alle vijf projecten wordt groepsverzorging geboden voor psychogeriatrische bewoners. Bij hen komt de zelfredzaamheid in verzorgingshuizen vaak in het gedrang. Ze kunnen zich meestal niet goed zelfstandig op hun eigen kamer handhaven en zijn ook regelmatig storend voor hun omgeving. Op de groepsverzorging wordt gepoogd om vanuit een methodische en programmatische aanpak en door middel van een groepsgewijze en individuele aandacht het zelfstandig functioneren te bevorderen of achteruitgang zoveel mogelijk tegen te gaan. Het op één plaats bijeenbrengen van, door hun gedrag, soms veel tijd en aandacht vragende bewoners, maakt een meer eficiénte organisatie mogelijk en leidt tot een vermindering van de druk voor de overige bewoners en het personeel van de reguliere afdelingen. Voorop staat dat alle deelnemers in hun eigen appartement blijven wonen. Zij gaan overdag naar de groepsverzorgingslocatic.

Het streven naar zorg op maat dient gestalte te krijgen in een individueel zorgplan voor elke substitutiepatiěnt. Tot op heden wordt nog maar in één project gewerkt volgens dit principe. In de overige projecten worden de zorgafspraken per projectdeelnemer nog veelal per discipline afgewerkt. Een apart multidisciplinair overleg (MDO) bestaat al in twee projecten. In alle projecten wordt nog veel bilateraal ad hoc overleg gevoerd.

De continuiteit in zorgverlening is niet overal' gerealiseerd. Inmiddels is wel in vier van de vijf projecten een 7-daagse zorgverlening gerealiseerd, doch slechts in één project, waar de deelnemers permanent gecentraliseerd zijn op één afdeling, een 7-daagse 24-uurs zorg. In de overige vier kan door het beschikbare budget slechts overdag extra groepsverzorging geboden worden en vallen de deelnemers 's avonds terug op de basale zorgverlening van het verzorgingshuis:

Van langdurige zorgverlening is in alle projecten sprake, ook al is de medische en paramedische bemoeienis per projectdeelnemer erg wisselend. Soms gaat het jaren goed in de groepsopvang en is nauweliiks extra medische/paramedische aandacht nodig.

Tẹn aanzien van de informatieverstrekking geven de geënquéteerde huisartsen aan tevreden te zijn over de kwaliteit van de medische rapportage betreffende hun substitutiepatiënten. Ook de geïnterviewde familieleden geven aan in het algemeen voldoende informatie te krijgen. Handhaving van de bewoner in het verzorgingshuis door de substiturie is voor hen in vele gevallen een belangrijk en vaak troostvol gegeven. De privacy van een eigen appartement wordt veruit verkozen boven die van een verpleeghuisbed. 


\section{Organisatie}

Het verpleeghuis heeft met elk verzorgingshuis bij de projectaanvang een samenwerkingsovereenkomst gesloten. Elk project kent een beheerscommissie, bestaande uit de verpleeghuisdirectie en de directie van het betreffende verzorgingshuis, die eindverantwoordelijk is voor het project en ook jaarlijks de projectbegroting vaststelt. Alle projecten worden volledig gesubsidieerd uit één structurele en twee tijdelijke financieringsbronnen. Op deze subsidiëring zelf wordt in dit artikel verder niet ingegaan. De gemiddelde dagprijs per project-deelnemer bedroeg in 1992 en $1993 \mathrm{ca}$. f 53,00 (spreiding: f 28,00 - f 84,00 ). Veruit het grootste deel van de subsidie zit in personeelskosten, waarvan het merendeel valt onder de noemer 'meer handen aan het bed' (= verzorgend personeel).

Zowel de directie van her verpleeghuis als die van de verzorgingshuizen geven aan dat de verschillende financieringsstromen, de jaarlijks wisselende dagprijs en de onduidelijkheid omtrent continuering van de financiering op langere termijn tot onduidelijkheid, onzekerheid en onnodige ambtenarij leiden en derhalve ongewenst zijn.

Op uitvoerend niveau zijn de eindverantwoordelijkheden als volgt vastgelegd. De huisartsen blijven eindverantwoordelijk voor de behandeling van de deelnemers. Ook de paramedici vanuit de eerste lijn hebben hun eigen behandelverantwoordelijkheid. De verpleeghuisarts is verantwoordelijk voor de complementaire medische advisering vanuit het verpleeghuis en voor de adviserende inzet van verpleeghuisparamedici en -psychologe. Het hoofd verzorging in het verzorgingshuis is als zorgcoördinator verantwoordelijk voor de dagelijkse gang van zaken op de projectlocatie en dient in feit de totstandkoming van een zorgplan voor elke deelnemer te waarborgen.

Over de medische eindverantwoordelijkheid, die in de projecten nu bij de huisartsen (31!) ligt, zijn de boeken lokaal, maar ook landelijk, nog niet gesloten. Uit de enquêtes en de interviews blijkt wel dat de samenwerking tussen huisartsen en verplecghuisartsen in de loop van de jaren is verbeterd en dat voor het maken van goede werkafspraken de zorgverlening beter op elkaar is afgestemd.

\section{Gevolgen voor de deelnemers}

De informatie verkregen uit de interviews en de enquêtes geeft een globale indruk van de gevolgen van de projecten voor de deelnemers. Voor veel deelnemers is uitstel of afstel van verpleeghuisopname gerealiseerd. Velen konden, door de complementaire substitutiezorg, tot hun overlijden in het verzorgingshuis blijven wonen (tabel 1). Hierover bestaat een grote satisfactie bij de familieleden en het verzorgend personeel.

Het verzorgend personeel geeft duidelijk aan dat de groepsverzorgingsactiviteiten ertoe leiden dat bij veel dementerende deelnemers overdag, door de aangebrachte structuur, minder onrust optreedt. Helaas ontstaat 's avonds, na terugkeer in het eigen appartement, bij meerdere psychogeriatrische deelnemers nog onrust omdat ze dan weer min of meer op zichzelf aangewezen zijn. Volgens de verzorgsters gaan veel dementerende deelnemers door de continue begeleiding beter eten en drinken dan wanneer ze alleen op een kamer blijven en het eten op het dienblad frequent onaangeroerd laten. Zij hebben voorts de indruk dat meerdere deelnemers door de groepsverzorging minder snel in dagelijks functioneren achteruit gaan; het gedrag zou vaker stabiliseren. Vooruitgang in zelfstandigheid 
wordt echter in hun ogen nauwelijks gerealiseerd; de deelnemers blijven dezelfde verzorgingshandelingen nodig hebben. Uit de interviews wordt ook duidelijk dat de deelnemers door de continue begeleiding vanuit het verpleeghuis meer consequent worden benaderd; principes van de realiteitsoriēntatietraining en van de validation-benadering zijn geleidelijk geìntroduceerd.

Tenslotte bestaat bij het verzorgend personeel en de familie de indruk dar door de aanschaf van verschillende hulpmiddelen, zoals rollators, orthopedisch schoeisel en aangepaste rolstoelen, de gemiddelde mobiliteit van vele deelnemers zeker verbeterd is. De fysiocherapeuten van het verpleeghuis bevestigen dit op basis van de waargenomen prestaties in de regelmatig georganiseerde looprondes met bewoners. De huisartsen zijn met name blij dat, door de toegenomen beschikbaarheid van loophulpmiddelen, de veiligheid van de mobiliteit beter gewaarborgd lijkt.

\section{Gevolgen voor het verzorgingshuis}

De directies en hoofden verzorging van de vijf verzorgingshuizen geven aan dat de reguliere bewonersafdelingen overdag rustiger zijn doordat de dementen elders zijn ondergebracht en niet meer rondzwerven of roepen; de controletaken van het verzorgingshuispersoneel zijn hierdoor verlicht. Aangegeven wordt dat de overige bewoners meer rust ervaren.

De verzorgingshuismedewerkers melden dat ze duidelijk meer deskundigheid hebben verworven in de omgang met dementerende bewoners en met complexe verpleegsituaties. Regelmatige bijscholingen, verzorgd door de verpleeghuisarts en -paramedici, inclusief psychologe worden zeer op prijs gesteld. Ook wordt in de interviews gewezen op het feit dat de deskundigheidsinbreng van de verpleeghuismedewerkers tot meer geriatrische preventie zou leiden. Problemen bij bewoners worden sneller gesignaleerd; ook de continue observatie op de groepsverzorging draagt hiertoe bij. Een belangrijk aspect is verder dat door de projecten, volgens het verzorgingshuispersoneel, een nauwer en frequenter contact met familieleden is ontstaan.

Een belangrijke toegevoegde waarde van de substitutie is ook dat bewoners van deze huizen die niet aan de projecten deelnemen toch kunnen profiteren van de verpleeghuisinbreng. Deze inbreng geschiedt consultatief, in afstemming met de huisarts en past in het genoemde preventie-aspect. Het aantal consulten voor niet-substitutiedeelnemers bedraagt per project, per jaar gemideld: verpleeghuisarts: 25 , ergotherapie: 20 , fysiotherapie: 30 , logopedie: 5 . Uit de enquêtes en de interviews blijkt dat deze toegevoegde waarde zou kunnen leiden tot een vermindering van de kans op aanmelding voor verpleeghuisopname van nietdeelnemende verzorgingshuisbewoners (zie ook tabel 2). Dit mogelijke gevolg verdient echter nader onderzoek.

\section{Gevolgen voor het verpleeghuis}

De omvang van de wachtlijst voor het verpleeghuis is in 1994 vergelijkbaar met die van vóór de start van de substitutieprojecten; de substitutiepatiënten blijven immers ook op deze wachrlijst staan. Door de meer adequate zorgverlening in de projecten valt de druk van deze deelnemers op de wachtlijst echter grotendeels weg; ze nemen als het ware een inactieve plaats in. Sinds de start van de projecten kunnen wel relatief meer ouderen vanuit thuis en vanuit het ziekenhuis 
opgenomen worden (tabel 2). Substitutiedeelnemers die uiteindelijk toch in het verpleeghuis opgenomen worden, vertonen in het algemeen een grote zorgbehoefte. Ook is de druk op de psychogeriatrische dagbehandeling vanuit de projecthuizen verminderd. De dagelijkse groepsverzorging ter plaatse reduceert volgens het verzorgingshuispersoneel de opvangproblemen beter dan intermitterende dagbehandeling. In de jaren 1991-1993 zijn er geen dementerende bewoners van de projecthuizen meer die dagbehandeling volgen, in tegenstelling tot de tijd vóór de start van de substitutie. De verpleeghuisdirectie en de -medewerkers geven duidelijk aan dat de samenwerking tussen het verpleeghuis en de projecthuizen aanzienlijk is verbeterd, zeker op zorgtechnisch- en scholingsgebied. Ook zijn de contacten tussen verpleeghuismedewerkers en eesste lijn (huisarts/fysiotherapeut) intensiever en opener geworden; ze worden door beide kanten als beter ervaren. Door het opnameteam van het verpleeghuis wordt wel gemeld dat, door de nu beschikbare mogelijkheden van zorgverlening, te weten dagbehandeling, consultatic, substitutieprojecten, dagverzorging, nachtverzorging, intramurale opname in verpleeg- en verzorgingshuis etc., meer en meer de noodzaak ontstaat om de verschillende zorgvormen duidelijker af te bakenen; dit geldt ook voor de doorstroming binnen deze zorgvormen. De behoefte aan een integrale indicatiestelling wordt derhalve groter.

\section{DISCUSSIE}

De vraag dringt zich op of de gegevens van dit inventariserende onderzoek passen binnen de bevindingen van het onderzoek van te Wierik et al. en andere onderzoeksgegevens. ${ }^{6.912}$ De projectdeelnemers hebben in onze ogen een terechte verpleeghuisindicatic, aangezien hier sprake is van een reguliere verpleeghuisscreening. Te Wierik et al. bevestigen de vergelijkbaarheid van substitutiepatiënten met patiënten die opgenomen zijn voor chronische verpleeghtiszorg. ${ }^{2}$ De in ons onderzoek aangegeven indruk dat de zelfstandigheid van de deelnemers meestal niet verbetert, past ook in de kenmerken van de doelgroep; het betreft namelijk veelal dementerende bewoners, bij wie het gaat om een progressieve aandoening. Dit vraagt om continue zorgondersteuning. Her stoppen van de substitutiezorg komt dan ook alleen maar voor door overlijden of door een verpleeghuisopname.

Substitutie lijkt in onze projecten daadwerkelijk te leiden tot afstel of uitstel van verpleeghuisopname. Voorts geeft dit onderzoek nog eens aan dat vaak geen sprake is van 24-uurs verpleeghuiszorg, noch van hetgeen 'pure verpleeghuiszorg' mag heten. Substitutiezorg zit dus tussen verzorgingshuiszorg en verpleeghuiszorg in. Men zou hier kunnen spreken van 'verzorgingshuiszorg plus'. Er dienen op korte termijn heldere profieleisen aan de projecten gesteld te worden, met regels voor de verantwoordelijkheden, taakstellingen en inzet van middelen en personeel, alsmede voor de zorginhoudelijke aspecten. Daarbij mag de dynamiek in de zorg op lokaal niveau niet teveel gehinderd worden, waardoor het mogelijk blijft. om in te spelen op reëel aanwezige behoeften. Verder moeten ook kwaliteitseisen aan de projecten gesteld gaan worden. Het rapport van te Wierik et al. alsmede het Kwaliteitshandboek Verpleeghuisvervangende Zorg van de Stichting GON geven hiervoor goede uitgangspunten. ${ }^{12.14}$

Substitutie van verpleeghuiszorg kan in ieder geval enig soelaas bieden voor de capaciteitsproblemen waarmee de verpleeghuissector worstelt. De toestroom. 
vanuit de verzorgingshuizen kan door de substitutie getemperd worden en de groeiende zorglast in de verzorgingshuizen kan enigszins het hoofd geboden worden. De samenwerking tussen verplecg-en verzorgingshuizen wordt er bovendien beter door. Natuurlijk zal de overheid moeten beslissen of het in gang gezette substitutiebeleid op langere termijn gecontinueerd wordt. Het lijkt onwaarschijnlijk dat gekozen zal worden voor beeindiging van deze ingezette trend. Ten eerste heeft de substitutie, zoals is beschreven, kwantitatief een enorme vlucht genomen. Ten tweede is het onttrekken van deze extra zorg aan verzorgingshuizen, waar nu verplecghuisgeïndiceerden wonen en door de vergrijzing waarschijnlijk altijd aanwezig zullen zijn, een irreèle optic. Ten derde wordt de privacy in verzorgingshuizen over het algemeen hogelijk gewaardeend en biedt de substitutie een acceptabele oplossing voor de kwantitatieve tekorten in verzorgingsmogelijkheden 'aan het bed'.

In de verpleeghuis- en verzorgingshuissector bestaat inmiddels een nadrukkelijke behoefte aan duidelijkheid omtrent het substitutiebeleid op langere termijn. De financiering zal eenduidiger en meer structureel moeten worden.

Ook is uit deze inventarisering gebleken dat aan het zorgniveau van de projecten nog duidelijk te werken valt. De impuls die de verpleeghuiswereld op dit moment zelf ondervindt in het streven naar een optimalisering van de zorg, o.a. door het verbeteren van individuele zorgplannen, adequaat multidisciplinair overleg en goed rapporteren, kan hierbij een uitstraling hebben naar de substitutieprojecten. ${ }^{15.16}$ Uiteindelijk zullen we daardoor steeds meer kunnen spreken over een zich positief ontwikkelende verpleeghuiszorg buiten de muren, in plaats van over surrogaat-verpleeghuiszorg. 


\section{LITERATUUR}

1. Verplecghuisworg in perspectief, beladsnota sectie verplerghuizen NZR, Utroche NZR, maarr 1989.

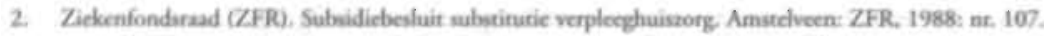

3. Schols JMGA. te Wierik MJM. Verplecghuisworg buiten de muren: daghehandeling, consulearic en substitutic. projecten. Ned. Tijdschr Geneskd 1993; 137:2717-22.

4. Laffre CRJ. Verdeniu W. Substinutie zonder betrokkenheid tor mislukken gedoemd. Medisch Contact 1989: 4: $114-8$.

5. Beer MFJM de, Fahrenfort M. Verplerghuisuorg buiten de muten. De rol van de huisarts. Mediuch Contact. 1993: 19: $597-9$

6. Blanken J.35 substituticprojecten getvaluect. 'Vennippering AWBZ gelden moet voorkomen worden'. Zotg en Ondememen 1993; $6: 20-4$.

7. Alem V van. Spijker J. Druk op verplecghuis omhoog door subotirutic. Hah 1994: 7: 304-6.

8. Keijuer JAL de. De achterkant van de substitutie. Medisch Contact 1994: 8: 259-61.

9. Boer $\mathrm{N}$ de. Substituties em anwinst in verplecghuisland? Eigen publikatie 1993.

10. Schols JMGA. Vanuit de praktijk Suhstirutie verplecghuiszorg. Vox Hospitii 1991; 15 (4): 96-9.

11. Schols JMGA, Substitutie verpleeghuisorg en consultatiefunctie verpleeghuizen: externe activiteiten van het hedendagese verplerghuis. Modem Medicine 1992; 16 (7/8); 619-24.

12. Wierik MJM te, Dijk P van, Stomph ECA, Frederiks CMA. Hollands L Subatitutieprojecten verplecghwisworg Een ondenoek naar zorgwarne en kwalitcitaupecten van zorg in verplecg- en vernorgingshuizen. Dwingeloo: KAVANAH. 1994.

13. Ziekenfondsraad (ZFR), Subsidiering substitutie verplecghuiszorg 1993. SGZ/23837. Amstelveen: ZFR. december 1992.

14. Kwaliteitshandbock Verplecghuis-vervangende Zorg. Stichting GON Nieuwegein, juni 1994.

48 15. Engbers-Kamps HJM, Sprundel van C. Model-zorgplan verplecghuiszorg. NVVz 5993.005. Utreche: NVVz, 1993.

16. Theunissen NJS. Ouderenzorg in beweging: een evaluatie van vijf substitutieprojecten verplecghuiszorg in het verzorgingshuis, Scriptie i.k.v. artsexamen KUN, Nijmegen 1994. 


\section{VERPLEEGHUISDAGBEHANDELING: EEN GROEIENDE FUNCTIE VOOR EEN TAMELIJK VAST OMSCHREVEN DOELGROEP}

J.M.G.A. Schots, D.H.M. Frijters, R.T.C.M. Koopmans, J.P.M. Diederiks,

F. Sturmans en H.F.J.M. Crebolder 


\section{SAMENVATTING}

Dit betreft een descriptief onderzock naar de kenmerken van in 1995 opgenomen en ontslagen verpleeghuisdagbehandelingspatiënten. Gegevens werden onteend aan het landelijke SIG Verpleeghuis Informatiesysteem (SIVIS), een patiëntgebonden registratie, waaraan in 1995 meer dan $85 \%$ van de verpleeghuizen deelnam. Van de startende dagbehandelingspatiënten was $89 \%$ ouder dan 65 en $39 \%$ ouder dan 80 jaar; zij werden verder gekenmerkt door een slechts geringe oververtegenwoordiging van vrouwen ( $9 \%$ meer dan mannen) en door een morbiditeitspatroon van chronische aandoeningen (somatiek: cva 45\%; psychogeriatrie: dementie $80 \%$ ). Deze morbiditeit ging gepaard met een aanzienlijke invaliditeit en beperkingen van de mobiliteit.

De meeste patiènten (78\%) kwamen vanuit het eigen huis. Zowel somatische als psychogeriatrische patiënten bezochten van opname tot ontslag gemiddeld driekwart jaar de dagbehandeling. Voor ruim 10\% van de somatische en $40 \%$ van de psychogeriatrische patiěnten mondde de dagbehandeling uit in een (aansluitende) verpleeghuisopname. De afgelopen tien jaar is de dagbehandelingscapaciteit in Nederland fors toegenomen en parallel daaraan het aantal patiènten dat gebruik maakt van deze voorziening. Opmerkelijk daarbij is dat de gemiddelde hulpbehoefte en behandelduur in die periode ongeveer gelijk zijn gebleven.

\section{SUMMARY}

Nursing home day-care: a growing function for a rather stable patient group

This article is a descriptive study of the characteristics of nursing home day-care patients in the Nerherlands in 1995 at furst admission and at discharge. Data were derived from the National Nursing Home Registration System (SIVIS), in which in 1995 over $85 \%$ of Dutch nursing homes participated. Newly admitted day-care patients were characterized by high age ( $89 \%$ older than 65 years), a distribution with (only!) 9\% more women than men and a morbidity pattern of chronic somatic (cerebrovascular disease 45\%) and psychogeriatric (dementia $80 \%$ ) disorders. This morbidity pattern was associated with a considerable degree of disability, in particular regarding the activities of daily living and mobility. Most patients $(78 \%)$ came from their own homes. The average length of stay from admittance to discharge. for both somatic and psychogeriatic day-care patients was nine months. For about $10 \%$ of the somatic patients and $40 \%$ of the psychogeriatic ones ambulatory day-care resulted in (subsequent) admission to the nursing home itself. In the last decade nursing home day-care capacity has increased rapidly and parallel to this also the number of day-care patients. Remarkably the average level of disability and the average period of treatment of nursing home day-care patients has remained approximately the same in this period. 


\section{INLEIDING}

De laatste rien jaar hebben een forse groei te zien gegeven van de verplecghuisdagbehandeling. Verklaringen hiervoor zijn de vergrijzing van de bevolking, de wens van de meeste hulpbehoevende ouderen en chronisch zicken om zolang mogelijk in de eigen woonomgeving te blijven én het op zorgsubstitutie gerichte overheidsbeleid, dat een accent legt op de thuiszorg in het algemeen en de ondersteuning hiervan in het bijzonder.'

Het aantal dagbehandelingsplaatsen steeg van 2.583 in 1985 tot 3.937 in 1995 (1.919 somatische en 2.018 psychogeriatrische). Op deze plaatsen werden in 1995 ongeveer 14.000 patiënten ambulant behandeld. ${ }^{23}$

De invulling en de funcrie van de semimurale verpleeghuiszorg worden bepaald door de aanwezige somatische of psychogeriatrische morbiditeit, de mate van invaliditeit, de mogelijkheden van herstel van verloren gegane functies, de behoefte aan nazorg na verpleeghuis- of ziekenhuisopname, de behoefte aan ondersteuning van de thuiszorg én uitstel van een definitieve verpleeghuisopname. Inzicht in de kenmerken van de patiènten, die gebruik maken van dagbehandeling, is van belang voor de kwaliteit, de afstemming en planning van de zorg, alsmede voor wetenschappelijk onderzoek. Ribbe e.a. beschreven de kenmerken van in het verpleeghuis opgenomen patiënten. Dit artikel biedt een beschrijving van de kenmerken van patiënten in de verpleeghuisdagbehandeling. ${ }^{3}$ De volgende vraagstelling werd daarvoor gehanteerd: Hoe ziet het profiel van somatische en psychogeriatrische patiënten eruit bij aanvang respectievelijk ontslag van hun dagbehandeling, voor de kenmerken: leefrijd, geslacht, herkomst, doel van de dagbehandeling, morbiditeit, validiteit, behandelduur, aantal behandelingen en ontslagbestemming; en in hoeverre zijn deze kenmerken ten opzichte van tien jaar daarvoor veranderd?

\section{METHODE}

Her betreft een beschrijvend onderzoek. De gegevens zijn afkomstig uit het landelijke SIG Verpleeghuis Informatiesysteem (SIVIS). Deze registratie, waaraan in 1995 meer dan $85 \%$ van de verpleeghuizen deelnam, is reeds eerder beschreven, ${ }^{4-0}$ Door middel van SIVIS worden, zowel voor klinische verpleeghuisals voor dagbehandelingspariënten gegevens vastgelegd bij, opname, per kwartaal en bij ontslag. De vastlegging geschiedt door de verpleeghuisarts en door het verplegend personeel. Het betreft personalia, herkomst, diagnosen, validiteit, aard en doel van de zorgverlening, behandelduur en gedragskenmerken.

In 1995 telde de verpleeghuisdagbehandeling in totaal 3937 plaatsen. Over 3374 $(85,7 \%)$ warẹn gegevens aanwezig in SIVIS. Uitgesplitst naar somatiek en psychogeriatrie was dit respectievelijk $1708(89,0 \%)$ en $1666(82,6 \%)$. De bij de beschrijving van de morbiditeit gehanteerde SIVIS-diagnoselijst is afgeleid van de ICD-9 Classificatie van Ziekten-80. Naast de hoofddiagnose kunnen 2 bijkomende diagnosen worden vastgelegd. De validiteit is beschreven in 22 validiteitsgegevens, die kunnen worden samengevat in drie schalen, de ADL, de mobiliteits- en de hulpindex. De validiteitsgegevens zijn verdeeld over de categorièn communicarie, activiteiten van het dagelijks leven (ADL), mobiliteit en continentie. De coderingsmogelijkheden zijn: 0 (geen hulp of toezicht), 1 (enige hulp of toezicht) en 2 (volledige hulp). De rubriek 'inhoud van de zorg' geeft inzicht in het doel van de zorgveriening. Coderingsmogelijkheden zijn 
'gangbare zorg' (passend bij langdurige opname > 6 maanden), 'paramedische zorg' (minstens $4 x$ per week en passend bij revalidatie-opname $<6$ maanden), 'gerichte observatie' en 'specifieke begeleiding'. Voor de meeste pariëntgegevens zijn de verschillen vermeld naar geslacht of naar het in de verpleeghuiswereld gangbare onderscheid in de aard van de zorg, dat wil zeggen somatisch of psychogeriatrisch. Hier en daar worden vergelijkingen met 1986 gemaakt om veranderingen in het profiel van de dagbehandelingspariènt ten opzichte van zo'n tien jaar geleden zichtbaar te maken.

\section{RESULTATEN}

\section{Leeftijd en geslacht bij opname}

Het totaal aantal patiënten dat in 1995 een aanvang maakte met dagbehandeling bedroeg 8727 (tabel I). In 1986 en 1991 waren dit respectievelijk 4993 en 7156 patiènten. Gecorrigeerd naar volledigheid van de SIVIS-registratie is er een toename in 1995 ten opzichte van 1986 van 43,6\%. Het aantal dagbehandelingsplaatsen is in dezelfde periode met $45,8 \%$ toegenomen. ${ }^{23}$

Bij de somatiek startten er in 1995 iets meer mannen dan vrouwen. Bij de psychogeriatrie startten er echter veel meer vrouwen, zodat per saldo de verhouding 54,5 - 45,5 vrouw-man was.

In 1995 was $89 \%$ van alle startende dagbehandelingspatiënten 65 jaar en ouder; $39 \%$ was 80 jaar en ouder (in 1986: resp. $87 \%$ en $34 \%$; in 1991: resp. $88 \%$ en $40 \%$ ). ${ }^{2,3}$ Beneden de leeftijd van 65 jaar bleken voor beide patiëntencategorieën relatief meer mannen dan vrouwen met dagbehandeling te beginnen.

\begin{tabular}{|c|c|c|c|}
\hline & somatiek & psychogeriatrie & totaal \\
\hline $\operatorname{man}$ & 51,3 & 39,5 & 45.5 \\
\hline vrouw & 48,7 & 60,5 & 54,5 \\
\hline $\mathrm{N}=100 \%$ & $4430^{\circ}$ & $4297^{\circ}$ & 8727 \\
\hline \multirow[t]{2}{*}{$\%$} & 50,8 & 49,2 & 100 \\
\hline & $<65$ joar & $65-80$ jaar & $>80$ joar \\
\hline $\operatorname{man}$ & 13,2 & 53,9 & 32,9 \\
\hline vrouw & 9,5 & 45,2 & 45.3 \\
\hline
\end{tabular}

TABEL 1

Aard van de zorg (somatiek/psychogeriatrie) en leeftijdsopbouw van đagbehandelingspatiènten naar geslacht (\%) bij aanvang van hun dagbehandeling in 1995.

\section{Herkomst en doel}

Opnamen vonden in 1995 het meeste plaats vanuit de eigen omgeving ( $78 \%$ ), gevolgd door het verzorgingshuis (13\%) en het verpleeghuis zelf (7\%) (tabel 2): Slechts een gering percentage kwam uit het ziekenhuis ( $2 \%)$; het betrof dan met name somatische patiënten. Ook de patiènten die na ontslag uit het verpleeghuis met dagbehandeling begonnen, behoorden vooral tot de somatische categorie. Ten opzichte van 1986 is hun aandeel van 10 tot $14 \%$ gestegen. Procentueel is het aandeel van startende psychogeriatrische dagbehandelingspatiënten vanuit het verzorgingshuis ten opzichte van 1986 met een derde teruggelopen (1986: 22\%, 1995: 15\%). ${ }^{2}$ 
Patiënten werden op de dagbehandeling voor uiteenlopende vormen van zorg opgenomen. Revalidatie (een behandeling korter dan 6 maanden) is het belangrijkste doel voor somatische patiēnten (59\%); langdurige opvang plus begeleiding (langer dan 6 maanden) het belangrijkste voor psychogeriatrische $(65 \%) .^{2}$

\section{Morbiditeit bij opname}

Bij de somatische patiënten was cerebrovasculaire pathologie de vaakst gestelde hoofddiagnose $(45,4 \%)$. Ook de overige chronische neurologische aandoeningen waren relatief sterk vertegenwoordigd $(17,6 \%)$, waarbij de ziekte van Parkinson als hoofddiagnose voorkwam bij $9 \%$ van de somatische patiēnten en multiple sclerose bij $2 \%$. Fracturen en status na heupoperatie kwamen als hoofddiagnosen voor bij $8,2 \%$ van de patiënten. De meest voorkomende niet-traumatische aandoeningen van het bewegingsapparaat bij de somatische patièntengroep betroffen artrose $(3 \%)$ en reumatoïde artritis $(2 \%)$.

De meeste bijkomende diagnosen werden voor somatische patiënten geregistreerd onder 'ziekten. van het hart-vaatstelsel' (w.o. decompensatio cordis, ischemische hartaandoeningen, hartritmestoornissen en hypertensie) $21 \%$, 'ziekten van het zenuwstelsel en zintuigen. (oog en oor)' $12 \%$, 'ziekten van het bewegingsapparaat' (met name artrose) $8 \%$ en 'psychische stoornissen' 7\%. Diabetes mellitus, nauwelijks als hoofddiagnose geconstateerd, was wel in $7 \%$ van de gevallen een bijkomende diagnose. ${ }^{23}$

Psychogeriatrische patiënten hadden bij aanvang van de dagbehandeling veelal dementie als hoofddiagnose $(80,3 \%)$. Voor een relatief grote groep was de

\begin{tabular}{|c|c|c|c|c|}
\hline TABEL 2 & & somatiek & psychogeriatrie & totoal \\
\hline dagbehandelings- & $1986(\%)$ & 2987 & 2006 & 4993 \\
\hline patiènten voor aanvang & eigen omgeving & 75 & 76 & 75 \\
\hline dagbehandeling & verzorgingshuis & 12 & 22 & 17 \\
\hline 1986/1995; & ziekenhuis & 3 & 1 & 2 \\
\hline $\begin{array}{l}\text { onderverdeeld naar } \\
\text { somatiek en }\end{array}$ & verpleeghuis & 10. & 1 & 6 \\
\hline \multirow[t]{5}{*}{ psychogeriatrie. } & 1995 (\%) & 4430 & 4297 & 8727 \\
\hline & eigen omgeving & 72 & 83 & 78 \\
\hline & verzorgingshuis & 11 & 15 & 13 \\
\hline & ziekenhuis & 3 & 1 & 2 \\
\hline & verpleeghuis & 14 & 1 & 7 \\
\hline
\end{tabular}

hoofddiagnose 'amnestisch syndroom' $(12,1 \%)$; $16 \%$ leed tevens aan hartvaatziekten (cva 5\%) en 3\% had m. Parkinson, 4\% diabetes mellitus, 10\% overige ziekten van het zenuwstelsel/zintuigen en $5 \%$ ziekten van het bewegingsapparaat (artrose 3\%). ${ }^{2.3}$

Ten opzichte van 1986 valt eigenlijk vooral op dat accenten wat steviger zijn aangezet. Was in 1986 cerebrovasculaire pathologie slechts hoofddiagnose bij $38,3 \%$ van de somatische patiënten, in 1995 was deze gegroeid tot $45,4 \%$. Zo ook zijn dementie en amnestisch sydroom als hoofddiagnosen bij psychogeriatrische patiënten toegenomen van $88,4 \%$ tot $92,0 \%$. 


\section{Voliditeit}

Bijna driekwart van de pariënten bleek hulp nodig te hebben bij 'wassen onder', waarvan ruim een kwart volledige hulp. Voor het ADL-item 'kleden' gold. eveneens dat bijna driekwart hulp behoefde en eenvijfde deel zelfs volledige hulp. Bijna de helft kon niet meer zelfstandig naar het toilet. Somatische patiënten waren bij deze items overigens wat vaker 'volledig hulpbehoevend' dan psychogeriatrische. De ADL (score 0-5) bedroeg bij starten van de dagbehandeling 2,80, hergeen gelijk is aan de waarde in $1986 .{ }^{2}$ De hulpindex (scorebereik 0-12), een optelsom van $\mathrm{ADL}$, mobiliteit en enkele kenmerken over incontinentie, oriëntarie en communicatievermogen is in dezelfde periode licht gedaald van 4,75 in 1986 naar 4,69 in $1995 .^{2}$

\begin{tabular}{lrrr} 
& somatiek & psychogeriatrie & totool \\
\hline 1986 (\%) & $2730^{*}$ & $1912^{*}$ & $4642^{*}$ \\
overteden & 4 & 4 & 4 \\
eigen omgeving & 50 & 20 & 37 \\
verzorgingshuis & 15 & 15 & 15 \\
ziekenhuis & 17 & 17 & 17 \\
verpleeghuis & 14 & 45 & 27 \\
& & & \\
1995(\%) & $4084^{*}$ & $3989^{*}$ & $8073^{*}$ \\
overleden & 4 & 5 & 45 \\
eigen omgeving & 59 & 31 & 13 \\
verzorgingshuis & 12 & 9 & 11 \\
ziekenhus & 12 & 41 & 27 \\
verpleeghuis & 13 & &
\end{tabular}

TABEL 3

Verblijfssituatie (\%) van dagbehandelingspatienten na definitief ontslag/ overtijiden (1986/1995); onderverdeeld naar somatiek en psychogeriatrie.

\begin{abstract}
- N.B. Deze aantallen ziinn lager dan het werkelijk aantal definitief ontslagen (SIVIS) patiènten, omdat de patiënten die naat een ander verpleeghuis voor dagbehandeling zijn ontslagen of naar onbekende of overige bestemming, er niet in zijn meegenomen.
\end{abstract}

Behandelduur, aantal behandelingen, bestemming en validiteit bij ontslag

Als we het staken van de dagbehandeling wegens overlijden buiten beschouwing laten, blijken patiënten in 1995 gemiddeld zo'n driekwart jaar behandeld te zịnn, waarbij er tussen somatische en psychogeriatrische patiënren nauwelijks verschil bestaat. Dezelfde duur werd ook al in 1986 gevonden. Het aantal behandelingen per week per patient was echter in 1995 duidelijk hoger dan in 1986. Bij somatische patiëriten bedroeg deze toename $8 \%$ tot 2,06 behandeldagen per week; bij psychogeriatrische zelfs $16 \%$ tot 2,53 dagen. Het aantal dagbehandelingen per patiěnt van eerste opname tot definitief ontslag was in samenhang met een nagenoeg gelijkblijvende behandelduur, maar met een toename van de behandelfrequentie, ten opzichte van 1986 gestegen met ca 17\% tot gemiddeld 91 dagen voor alle dagbehandelingspatiënten.

Het grootste deel van de somatische patiënten $(71 \%)$ had de eigen omgeving of het verzorgingshuis als (aansluitende) ontslagbestemming (tabel 3). Het aantal psychogeriatrische patiënten met deze bestemming was aanmerkelijk lager (45\%). Een aanzienlijk deel werd opgenomen in het verpleeghuis ( $41 \%)$; bij de somatische patiënten gold dit maar voor $13 \%$. 
Slechts een klein deel van de patiënten werd in 1995 uitgeschreven wegens overlijden ( $5 \%$ ). Aannemelijk is echrer dat een belangrijk deel van de in het ziekenhuis opgenomen patiënten aldaar overleed.

Ten opzichte van 1986 valt op dat in 1995 een groter percentage patiènten naar de eigen omgeving werd ontslagen en een kleiner naar het ziekenhuis. Deze trend is vooral bij psychogeriatrische patiënten zichtbaar.

Bij ontslag is slechts een deel van de patiěnten (bijna) geheel ADL-zelfstandig. Een groot deel van de somatische en psychogeriatrische patiënten vertoont nog forse ADL-beperkingen. In figuur 1 wordt de ADL-index over 1995 gerelateerd aan de ontslagbestemmingen in dat jaar. Van de somatische patiënten die naar hun eigen omgeving $(\mathrm{n}=2553)$ danwel her verzorgingshuis gingen $(\mathrm{n}=520)$ was ruim eenderde geheel of bijna geheel ADL-zelfstandig; eenderde deel was vrijwel geheel ADL-onzelfstandig en had bij 4 of 5 van de ADL-items hulp nodig. Van deze laatsten gingen er toch nog circa 800 naar hun eigen omgeving en bijna 290 naar een verzorgingshuis. Van de somatische patiënten die na ontslag naar het ziekenhuis en het verpleeghuis gingen, was respectievelijk $59 \%$ en $78 \%$ (bijna) geheel ADL-onzelfstandig. Voor psychogeriatrische patiënten gold dat in beide gevallen voor tweederde deel. Ontslagen psychogeriatrische patiënten die naar hun eigen omgeving danwel het verzorgingshuis gingen, waren in respectievelijk een kwart van de gevallen ADL-zelfstandig en in de helft ADL-onzelfstandig. De percentages van 1986 verschilden hierbij nauwelijks van die in 1995.

FIGUUR 1

Ontslagen

dagbehandelings-

patiēnten 1995

(somatiek/psychogeriatrie), procentueel

uitgesplitst naar index var activiteiten. van het dagetijks leven (ADL), en ontslagbestemming.
ADL-index:

0 en 1

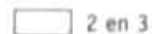

2 en 3

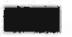

4 en 5

somatiek

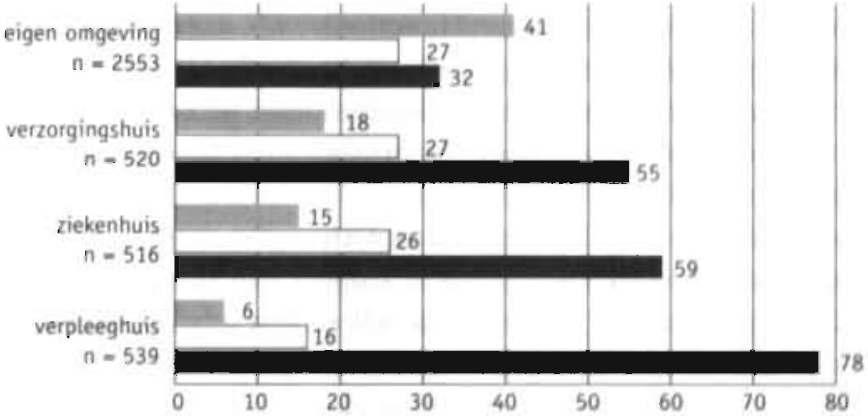

psychogeriatrie

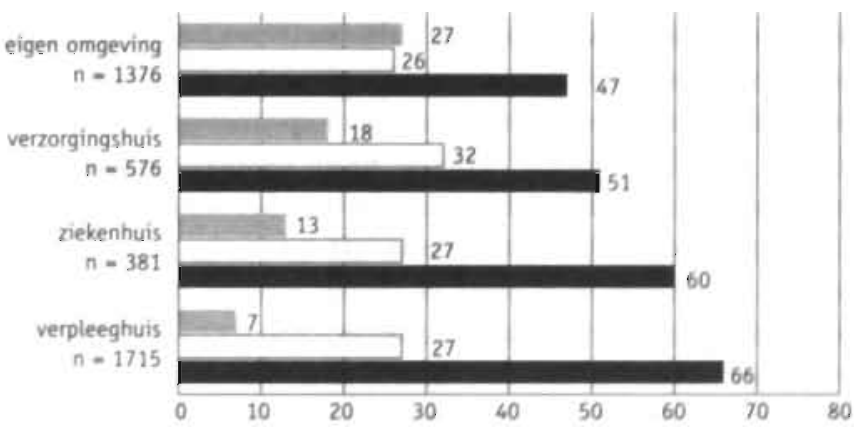




\section{BESCHOUWING}

De SIVIS-registratie biedt de mogelijkheid om een profiel te beschrijven van in het verpleeghuis opgenomen patiënten en van patiënten die in het verpleeghuis voor dagbehandeling komen. Het totale bestand betreft inmiddels patiëntengegevens over bijna 20 jaar.

Foutenbronnen zitten ondermeer in de nauwkeurigheid waarmee artsen, verpleegkundigen en administratief medewerkers de registratieformulieren invullen, ook al biedt het SIVIS-gebruikershandboek duidelijke richtlijnen. Persoonlijke gegevens betreffende de patiënten zijn redelijk betrouwbaar te noemen; bij andere gegevens, zoals doel van opname, diagnosen en validiteit kunnen subjectieve interpretaties en coderingsmogelijkheden van de registratie een rol spelen. ${ }^{46}$ De nieuw opgenomen dagbehandelingspopulatie is over het algemeen oud. De vrouwen zijn in de meerderheid, maar verhoudingsgewijs zijn er weinig vrouwen, indien de verdeling man-vrouw wordt vergeleken met de totale Nederlandse bevolking met eenzelfde leeftijdsopbouw. Een verklaring hiervoor kan zijn dat er bij dagbehandeling van een thuiswonende mantelzorg moet zijn voor wanneer de patiënt niet op de dagbehandeling in het verpleeghuis is. Mantelzorg wordt in belangrijke mate door de echtgenoot/echtgenote gegeven. Meestal betreft dat echtgenotes, die zijn jonger dan hun zieke partner, en meer gewend zijn zorg te geven.

Opname op de verpleeghuisdagbehandeling vindt bij somatische en psychogeriatrische patiënten voornamelijk plaats vanuit de thuissituatie. Dit in tegenstelling tot in het verpleeghuis opgenomen patiënten, waarvan het merendeel wit het ziekenhuis komt. ${ }^{2 A}$ De verklaring hiervoor is waarschijnlijk dat verpleeghuisdagbehandeling twee doelen heeft: (a) de mantelzorg te ontlasten en (b) opname in een instelling te voorkomen of uit te stellen. Beide doelen veronderstellen de aanwezigheid van een functionerende mantelzorg.

Opname in het verpleeghuis daarentegen gebeurt - vooral - (a) omdat mantelzorg ontbreekt of de zorg niet (langer) aankan, hetgeen vaak geconstateerd wordt op het moment van een ziekenhuisopname en (b) voor revalidarie na een behandeling in het ziekenhuis.

In de herkomst bij aanvang hebben ten opzichte van 1986 wel een aantal veranderingen plaatsgevonden: een relatieve stijging van het aantal somatische patiënten afkomstig vanuit het verpleeghuis zelf en een relatieve daling van het aantal psychogeriatrische patiënten vanuit het verzorgingshuis. Het eerste hangt waarschijnlijk samen met de energie die de verpleeghuissector heeft gestoken in de ontwikkeling van de revalidatiefunctie, waarbij in het nazorgtraject nogal eens voor een periode van dagbehandeling gekozen wordt. Het andere heeft ongetwijfeld te maken met: het ontstaan van de substitutie van verpleeghuiszorg, die in veel verzorgingshuizen heeft geleid tot de start van meerzorg- en groepsverzorgingsprojecten voor bewoners, die aan respectievelijk somatische en psychogeriatrische pathologie lijden.' Hierbij moet worden opgemerkt dat het absolute aantal psychogeriatrische patiënten, dat uit het verzorgingshuis komt, sinds 1986 wél is gestegen, als gevolg van de groei in het aantal dagbehandelingsplaatsen. Bovendien is er door de daling van het totale aantal verzorgingshuisplaatsen in Nederland (van ca. 138.000 in 1986 tot ca. 125.000 in 1995)* ook sprake van een toename van het aantal dagbehandelden op het aantal aanwezige verzorgingshuisplaatsen. Deze toenames zouden echter nog veel groter 
zijn geweest als het percentage psychogeriatrische patiënten, afkomstig vanuit de verzorgingshuizen, in 1995 gelijk was gebleven aan dat van 1986.

In de afgelopen tien jaar blijkt de somatische dagbehandelingspatiënt vaker een hart-/vaatprobleem als hoofddiagnose te hebben gekregen bij start van de dagbehandeling en de psychogeriatrische patiènt vaker de diagnose dementie. Die morbiditeit gaat gepaard met een flinke mate van invaliditeit, waarbij de gemiddelde hulpbehoefte (ADL-index) van de patiënten, zowel bij aanvang als staken van de dagbehandeling, overigens wel lager blijkt te liggen dan die welke beschreven is voor patiënten die in het verpleeghuis opgenomen, respectievelijk ontslagen worden." Dit beeld kan echter goed passen bij de tijdelijke, aanvullende functie, die de dagbehandeling vaak vervult voor de thuiszorg en/of voor definitieve opname in een instelling.

Opmerkelijk is dat, ondanks een duidelijke groei van de capaciteit en een daaraan gekoppelde flinke toename van het aantal patiënten, de gemiddelde hulpbehoefte en behandelduur in tien jaar tijd bijna precies gelijk zijn gebleven, waarbij in dit rijdsbestek overigens wel sprake is van een toename van de behandelintensiteit. Dit betekent dat er een toenemend aantal patiènten met ongeveer dezelfde zorgbehoefte is, in een tijdperk dat er sprake is van lange wachtrijden voor opname in een verpleeghuis en waarin patiënten in het algemeen ook zolang mogelijk thuis willen blijven en ook de overheid een versterking van de thuiszorg nastreeft. ${ }^{\text {. }}$

Bijna de helft van alle in 1995 ontslagen patiënten kon (aansluitend) naar de eigen woonomgeving ontslagen worden; een duidelijke stijging ten opzichte van 1986. Terwijl bijna tweederde van de somatische patiënten daarheen ontslagen kon worden, moest van de psychogeriatrische een groot deel in het verpleeghuis opgenomen worden.

De complementaire functic van de dagbehandeling vertoont dus een aantal belangrijke kenmerken. Voor somatische pariënten kunnen immers zowel primaire revalidatie, als nabehandeling na klinische revalidarie plaatsvinden; voor veel psychogeriatrische vormt de dagbehandeling echter een overbrugging tot definitieve opname in het verpleeghuis. Het verdient aanbeveling om een meer gedetailleerde longitudinale studie te verrichten bij dagbehandelingspatiënten om zo meer inzicht te krijgen in hun zorgcarrière. Een dergelijke studie kan ook meer inzicht verschaffen in aspecten als, bijvoorbeeld, de relatie behandelduur versus validiteit of bestemming bij ontslag.

Als een patiënt uit de dagbehandeling ontslagen wordt, betekent dat niet dat hij ADL-zelfstandig is. Meer dan de helft is nog aanzienlijk geinnalideerd. Wellicht kan de tijdelijke zorg op de dagbehandeling, die veelal plaatsvindt in aanvulling op de thuis- en mantelzorg, voor vele thuis of in het verzorgingshuis verblijvende patiënten een zodanige ontlasting en herstel van stabiliteit, c.q. draagkracht, opleveren dat, na ontslag, ondanks de resterende hulpbehoefte, toch handhaving ter plaatse mogelijk blijft. Prospectief onderzoek is nodig om na te gaan hoelang dit eventuele effect aanhoudt.

Andere redenen zouden kunnen zijn dat de patiënten en of de mantelzorg zelf weer kiezen voor zorg zonder dagbehandeling of dat er een alternatief ontstaat via de thuiszorg. 


\section{LITERATUUR}

1. Schols JMGA, Wierik MJM te. Verplecghuisworg buiten de muren: daghehandeling, consultatie en substiruticprojecten. Ned Tijdschr Geneeskd 1993; 137: 2717-22.

2. SIVIS-dara verplecghuizen 1986-1995. SIG-databestand, Utrechr.

3. SIVIS jarboeken 1986-1995, SIG Zorginformatic, Utrecht.

4. Ribbe MW, Frijtens DHM, Mens J TH van. Kenmerken van verplecghuispariènten bij eerste opname leeftijd, gedachr en morbiditeit. Ned Tijdschr Genceskd 1993; 137: 2544-8.

5. Ribbe MW, Mens J Th van, Frijters DHM. Kenmerken van patienten vijdens verblijf in het verpleeghuis en bij onsalag. Ned Tijdschr Genesskd 1995: 139: 123-7.

6. Stichting Informatiecentrum voor de Gezondheidstorg (SIG). Gebruikenshandboek SIVIS.

Utreche: SIG, 1990 (rogelm. updating).

7. Schols JMGA, Theunissen NJS. Bors V. Sinnema ME. Verplecghuiszorg in beweging een inventariserend overzichr van vif subatitutieprojecten verplecghuiszorg. Tijdschr Gerontol Geriatr 1995: 26: 10-5.

8. Ministerie van VWS. Zorg in Geral 1996. Rijwijk: VWS, 1996.

9. Nies HLGR. Dagbehandeling? Een tusentijdse balans van dagbehandeling in verplecghuizen. Tijdschr Gerontol Geriatr 1986; 17; 25-32. 


\section{DE SAMENWERKING VERPLEEGHUISARTS - HUISARTS NADER ONDERZOCHT}




\section{INLEIDING}

थ 
In dit deel wordt verslag gedaan van onderzocksactiviteiten die verricht zijn met betrekking tot de samenwerking tussen huisarts en verpleeghuisarts. Demografische ontwikkelingen en verwachte veranderingen in de gezondheidszorg, waarnaar ook in andere hoofdstukken gerefereerd is, maken de samenwerking. tussen huisarts en verplecghuisarts tot een actueel en relevant onderwerp.

Volgend op deel 2, waarin aandacht werd besteed aan de hedendaagse transmuralisering van de verpleeghuiszorg, is aandacht voor de samenwerking tussen huisarts en verpleeghuisarts een logisch uitvloeisel van de toenemende transmurale contacten die tussen beiden zullen gaan plaatsvinden. 


\section{SAMENWERKING TUSSEN HUISARTS EN VERPLEEGHUISARTS \\ TWEE ACTOREN IN EEN VERANDERENDE OUDERENZORG}

J.M.G.A. Schols, J.P.M. Diederiks en R.T.C.M. Koopmans 


\section{SAMENVATTING}

Samenwerking in de zorg is een belangrijk adagium geworden. In dit artikel wordt, na een algemene beschrijving van de veranderingen in de ouderenzorg, ingegaan op de overeenkomsten en verschillen tussen de huisarts- en verpleeghuisgeneeskunde. Deze betreffen zowel de inhoud van de vakgebieden als de plaats in het gezondheidszorgsysteem. Modellen van samenwerking worden beschreven.

\section{SUMMARY}

Cooperation between general practitioner (GP) and nursing home physician (NHP); two workers in a changing care for the elderly

Nowadays cooperation is an important issue in health care. After a description of the major alterations in the care for the elderly, this article addresses specifically the similarities and differences between nursing home medicine and general practice. These concern the contents of both disciplines and their positions in the health care system. Models of cooperation are presented. 


\section{INLEIDING}

Op de markr van de ouderenzorg is een scala aan zorgaanbieders actief. Er bestaan op dit moment gerede twijfels of de totale zorg verleend wordt als een gecoördineerde en ononderbroken reeks van activiteiten, in overeenstemming met de behoeften en belangen van de zorgvragers. Continuïteit van zorg wordt pas bereikt indien sprake is van zowel afstemming van de hulpverlenende activiteiten op de behoeften van de patiènt, alsook, in aansluiting op de mogelijkheden van de mantelzorg, van afstemming van de activiteiten van de afzonderlijke hulpverleners. Ten aanzien van de verschillende hulpverleners in de ouderenzorg veronderstelt dit dat hun individuele deskundigheden elkaar aanvullen. De huisarts en de verplecghuisarts zijn twee van die hulpverleners die actief opereren in de ouderenzorg.

In dit artikel wordt, na een algemene beschrijving van de veranderingen in de ouderenzorg, specifiek op de samenwerking tussen de verpleeghuisarts en de huisarts ingegaan.

\section{DE VERGRIJZING EN DE DRUK OP DE ZORGVOORZIENING}

De demografische ontwikkeling in de westerse landen leidt tot het opvallende verschijnsel van ontgroening en vergrijzing. Niet alleen stijgt het aantal 65 plussers gestaag, ook het aantal 75-plussers neemt aanmerkelijk toe. Tussen nu en $2015 \mathrm{zal}$ het aantal 65-plussers toenemen van 2 miljoen tot 2,9 miljoen en het aantal 75-plussers van ruim 850.000 tot bijna 1,2 miljoen.' Men duidt dit aan met de term dubbele vergrijzing. Meer ouderen betekent echter ook dat binnen de oudere bevolkingsgroep ziekte en invaliditeit zullen toenemen. Het absolute aantal patiënten met chronische, somatische aandoeningen (diabetes mellitus, COPD, artrose, cardiaal lijden, cerebrovasculair lijden, m. Parkinson etcetera) zal over de periode 1990 tot 2010 toenemen met ruim 30\%.

Ook het aantal ouderen, lijdend aan dementie, zal fors toenemen. De Nationale Raad voor de Volksgezondheid berekent een toename van het aantal patiënten met een dementiesyndroom van 133.000 in 1990 tot circa 175.000 in 2005. Dit is eveneens een toename van $30 \% .^{\prime}$

Binnen de gezondheidszorg wordt dan ook gerekend op steeds meer zorgbehoeftige ouderen. De dan, logischerwijs verwachte, hogere vraag naar voorzieningen in de gezondheidszorg en de daarmee samenhangende toenemende kosten zijn de voornaamste redenen waarom zorgvragers, zorgaanbieders en zorgverzekeraars zich zorgen maken over de vergrijzing en dubbele vergrijzing. Als de overheid dan ook nog opteert voor een reductie van het aantal bejaardenhuisplaatsen; als het aantal verpleeghuisbedden bevroren wordt op het huidige aantal en ook de ziekenhuissector het laatste decennium een forse beddenreductie te zien heeft gegeven, dan is het dilemma in de zorgsector duidelijk. Aan de ene kant een toenemende zorgbehoefte bij een sterk vergrijzende groep ouderen; aan de andere kant de financiële beperkingen voor de instellingen, waardoor deze niet meer adequaat tegemoet kunnen komen aan de verwachte vraag naar zorg." Naast de grote groep ouderen die nu al tot aan het levenseinde thuis verblijft (circa 90\%), houdt een en ander in dat in de nabije toekomst voor steeds meer mensen die nu nog worden opgenomen, een oplossing buiten de muren van de zorginstellingen gevonden zal moeten worden. Op termijn zal in tegenstelling tot circa $9 \%$ van de ouderen nu, nog maar $6 \%$ in een zorginstelling mogen 
verblijven. Er zal derhalve sprake moeten zijn van een forse uitbreiding van de thuiszorgmogelijkheden.

\section{VERANDERINGEN IN DE INTRAMURALE ZORGSECTOR}

De grootste verandering in het toekomstige beleid betreft de verpleeghuizen en de verzorgingshuizen. De huidige verpleeghuizen worden straks exclusief bestemd voor zwaar gedragsgestoorde dementen, voor ouderen die intensieve en complexe verpleging nodig hebben en voor ouderen die kortdurend voor revalidatie worden opgenomen. Andere langdurig, maar minder intensief zorgbehoevende ouderen, lijdend aan ofwel dementie ofwel een chronische, somatische aandoening, zullen, indien nodig, steeds vaker opgenomen worden in de verzorgingshuizen.

Waren de verzorgingshuizen in het begin van de jaren zeventig primair wooninstituten voor bejaarden met de mogelijkheid tot het verkrijgen van lichte aanvullende verzorging, de laatste twee decennia hebben ze zich steeds meer ontwikkeld tot zorgvoorzieningen voor ouderen. Gelet op de doelgroepen worden verzorgingshuizen en verpleeghuizen dan ook als natuurlijke partners beschouwd.

Als op termijn de verzorgingshuizen eveneens vanuit de AWBZ bekostigd zullen worden, zal bovendien een belangrijke financiële barrière voor samenwerking tussen de bejaardenoorden en verpleeghuizen verdwijnen. Bovendien treedt dan ook een harmonisatie op van de verschillende eigen-bijdrage-systemen om oneigenlijke prikkels voor gebruikers uit het hele zorgsysteem re halen." Als gevolg van deze

66 ontwikkelingen ziet men geleidelijk overal in het land samenwerkingsverbanden ontstaan tussen verpleeghuizen en verzorgingshuizen.

Een andere, door de overheid voorgestane, ontwikkeling betreft de substitutie van intramurale zorg in de eerste lijn. Verpleeg- en verzorgingshuizen zullen daarbij hun expertise meer en meer buiten de muren kunnen en moeten inzetren om zo een bijdrage te leveren aan het oplossen van de groeiende zorgvraag in de eerste lijn.

\section{ACCENT OP DE THUISZORG}

Verwacht mag worden dat de thuiszorg in toenemende mate te maken zal krijgen met mensen die in hun vermogen tor zelfzorg ernstig beperkt zijn en die in toenemende mate ook technische hulpmiddelen nodig hebben om een nog enigszins draaglijk bestaan te hebben. Een uitsluirend op ziekte en behandeling gericht medisch zorgmodel zal dan onvoldoende soelaas bieden. Bij hulpbehoevende ouderen en mensen met chronische ziekten wordt het toestandsbeeld immers door vele verschillende variabelen bepaald. Voor elke individuele patiènt spelen naast de ziekteaspecten, de psychosociale factoren en de op de genezing gerichre activiteiten, ook de mogelijkheden en beperkingen van het sociale systeem en de begeleiding een belangrijke rol. Dit vraagt om een zorgmodel met een meer probleemgerichte en patiëntgeoriënteerde benadering dan waarvan in de curatieve zorg in de regel sprake is.

De tekorten in de zorg dienen per patiënt vertaald te worden in concrete zorgbehoeften, die op hun beurt een specifieke indicatie zijn voor de gewenste zorgverlening. ${ }^{14}$

In een adequate thuiszorg zijn dan de volgende aspecten belangrijk: ${ }^{15}$ 
- medische en verplecgkundige kennis en vaardigheid;

- huishoudelijke en organisatorische ondersteuning;

- psychologische en sociale ondersteuning;

- fysiotherapie en eventueel ergotherapie.

De huishoudelijke en organisatorische ondersteuning wordt vaak voor een deel door de mantelzorg of door vrijwilligers geboden en daar waar dit niet kan, wordt deze leemte door professionele gezinsverzorgenden opgevuld. Ook de sociale steun komt voor een groot deel vanuit de mantelzorg. De overige functies vereisen een zekere professionaliteit.

Adequate thuiszorg vereist daarnaast goede afspraken over: ${ }^{16}$

- de samenwerking, dat wil zeggen de bereidheid en bekwaamheid van hulpverleners om, goed communicerend en elkaar aanvullend, op flexibele wijze samen te werken;

- de continuïteit en bereikbaarheid, dat wil zeggen het voorkomen van hiaten, tegenstrijdigheden en overlappingen in de zorg.

Anders omschreven: bij kwalitatief goede en doelmatige thuiszorg dient in feite voldaan te worden aan een optimale continuïteit, complementariteit, communicatie en coördinatie! ${ }^{\text {s.? }}$

\section{SAMENWERKING IN DE ZORG IS HET ADAGIUM}

Omdat ook de thuiszorg vanuit de AWBZ gefinancierd wordt, ontstaan in de nabije toekomst ideale mogelijkheden voor strategische en praktische samenwerking tussen alle partijen in de zorgsector. Steeds meer kan dan gestreefd worden naar een zorgcontinuüm, van thuiszorg aan de ene kant tot institutionele zorg aan de andere kant."

De nu aanwezige 'muren' tussen de partijen in het veld moeten, als het aan de overheid ligt, geslecht worden. Vanuit een uniforme financiering via de AWBZ zal her dan niet meer uitmaken waar en door welke zorgaanbieder of coöperatie van zorgaanbieders de zorg geboden wordt. De overheid kiest bovendien voor een model waarin de zorgverzekeraars de eindverantwoordelijkheid hebben voor de zorg.

De zorgaanbieders, zowel intramuraal als extramuraal, zullen er door een goede samenwerking voor kunnen zorgen dat de gewenste zorgverlening efficiènt, doelmatig en tegen een zo gunstig mogelijk tarief aangeboden wordt.

In dit licht is het begrijpelijk dat op dit moment al diverse samenwerkingsinitiatieven ontstaan tussen verpleeghuizen/verzorgingshuizen enerzijds en thuiszorgorganisaties anderzijds. Figuur 1 toont op schematische wijze de 'ouderenzorgketen' en geeft ook aan hoe de patiëntenstromen tussen de verschillende zorginstellingen verlopen.

\section{ONTWIKKELINGEN IN DE RELATIE VAN VERPLEEGHUISARTS EN HUISARTS}

De huisarts staat midden in deze geschetste veranderingen in de organisatic van de zorgsector in het algemeen en de ouderenzorg in het bij̨zonder. Hij wordt als poortwachter van de gezondheidszorg gezien en is voorts de eerstverantwoordelijke medicus in de thuiszorg en van oudsher bij uitstek de 'thuisarts'. In een kwantitatief meer intensieve thuiszorg zal de huisarts meer zorggericht moeten gaan 


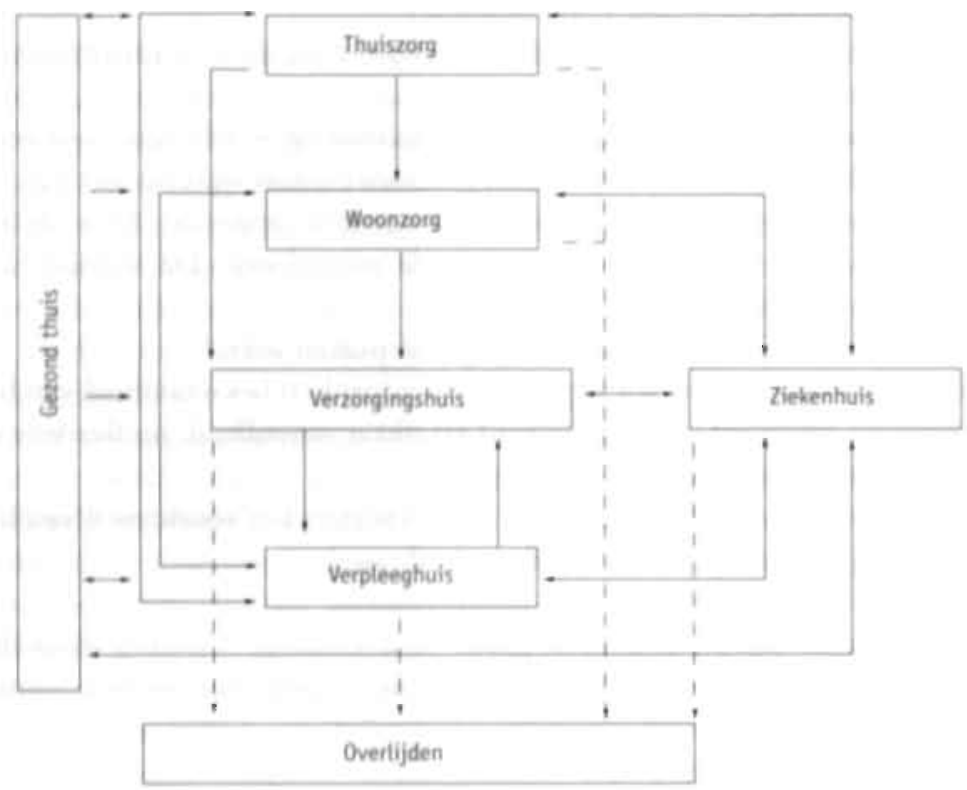

de chronische

ouderenzorg in

Nederland

(diagnost-project)

naar:

Heyne G.

Vermaas 3.

Wuistefeld $\mathrm{C}$.,

Joldersma C.,

Geurts J.

I.V.A., 1995.

Tilburg.)

opereren en men verwacht dat hij, nog meer dan vroeger, een medebepalende en belangrijke rol zal gaan spelen in het totale circuit van verzorging, verpleging en behandeling van patiënten in de thuissituatie.

Dit circuit, dat aan voortdurende verandering onderhevig is, wordt gerealiseerd met behulp van zelfzorg, mantelzorg, vrijwilligerswerk en aanvullende professionele zorg vanuit de eerstelijn (met name kruiswerk en gezinszorg) met ondersteuning van de tweedelijn (ziekenhuis en verpiceghuis).

In het licht van de geschetste ontwikkelingen ten aanzien van de thuiszorg ontstaan ook mogelijkheden voor een goede samenwerking tussen verpleeghuisarts en huisarts. Aandacht voor deze samenwerking is niet alleen belangrijk vanuit inhoudelijk oogpunt, maar zelfs noodzakelijk vanwege de ontwikkeling van de extramurale verpleeghuiszorg.

Sinds 1987 zijn immers de mogelijkheden voor het verpleeghuis om buiten de muren zorg te verlenen, aanmerkelijk verruimd."

Doorgaans heeft een contact tussen huisarts en verpleeghuisarts met primair als doel het realiseren van een verpleeghuisopname. Veelal wordt daarbij een, via een indicatiecommissie verlopende, schriftelijke procedure gehanteerd. Een en ander kan echter door middel van telefonisch contact tussen huisarts en verpleeghuisarts nader toegelicht worden. Uit ervaring blijkt dat het initiatief wisselend bij beide partijen ligt. Huisartsen grijpen vooral naar de telefoon om de urgentie te onderstrepen. Wanneer een patiènt vervolgens wordt opgenomen in het verpleeghuis betekent dit in de meerderheid van de gevallen een langdurig verblijf. Geconstateerd moet worden dat veel langdurig in het verpleeghuis verblijvende patiënten, dan geleidelijk uit het gezichtsveld van de huisarts verdwijnen. Anders ligt dit bij patiēnten die in het verpleeghuis zijn opgenomen ter revalidatie. De huisarts 
moet bij ontslag van deze patiënten op tijd ingelicht worden, om zodoende de medische zorg weer te kunnen overnemen. ${ }^{10}$

De samenwerkingsrelatie van huisartsen met verpleeghuizen en verpleeghuisartsen is in de praktijk zeer heterogeen. Deze blijkt sterk bepaald te worden door factoren als vergrijzing van de huisartsenprakrijk, omvang van de praktijk en affiniteit van de huisarts met langdurige en geriatrische zorg."

Aangrijpingspunten voor samenwerking tussen huisarts en verplecghuisarts liggen vooralsnog vooral op het vlak van de consultatie en het opname- en ontslagbeleid.

De ontwikkeling van de verplecghuisdagbehandeling eind jaren zeventig, is trendsetter geweest voor een intensivering van het contact tussen verplecghuisarts en huisarts. Aangezien de semimurale dagbehandeling een complementaire voorziening is waarbij thuiszorg en institutionele zorg elkaar moeten aanvullen, kan het niet anders zijn dan dat ten behoeve van de betrokken patiènten een goed en geregeld overleg plaatsvindt tussen verpleeghuisarts en huisarts.

De manier waarop dit overleg geschiedt en de frequentic, kunnen regionaal verschillen. Desalniettemin hebben veel huisartsen via de dagbehandeling de mogelijkheden en onmogelijkheden van het verpleeghuis goed leren kennen. ${ }^{202 i}$

De laatste tien jaar zijn de mogelijkheden voor samenwerking tussen huisarts en verpleeghuisarts nog groter geworden. In 1987 werd de consultatiefunctic operationeel, waarbij aan onder anderen huisartsen de mogelijkheid geboden werd om ten behoeve van thuiswonende patiènten advies in te winnen bij het verpleeghuis."2

Vervolgens ontstond na 1988 de substitutie van verpleeghuiszorg in de eerste lijn. ${ }^{i 2 s}$ Gaat het bij dagbehandeling en consultatie voornamelijk om patiènten voor wie (nog) geen. noodzaak tot opname bestaat, bij substitutie van verpleeghuiszorg wordt een (tijdelijk of blijvend) alternatief geboden aan patiènten die in principe al verpleeghuisgeindiceerd zijn.

Via substitutie kunnen deze mensen thuis of in het verzorgingshuis de nodige ondersteuning van het verpleeghuis ontvangen. Het verpleeghuis levert hierbij zorg en behandeling op maat, die complementair is aan de zorg die deze patiènten al ontvangen. De veelal projectgewijs opgezette substitutie van verpleeghuiszorg is vooral in verzorgingshuizen gemeengoed geworden. Projecten in de thuissituatie zijn er nog niet veel.

De diverse projecten blijken overigens, een erg gevarieerd beeld te vertonen. ${ }^{24 y}$

Het welslagen is sterk afhankelijk van de kwaliteit van de samenwerking en van de mate waarin de afzonderlijke zorgverantwoordelijkheden zijn vastgelegd.

Omdat de substiturie in feite primair unilateraal gericht is - namelijk van verpleeghuis richring eerste lijn -- ontstonden er aanvankelijk her en der samenwerkingsproblemen tussen huisartsen en verpleeghuisartsen. De huisartsen voelden zich als het ware overvallen door het plotseling in de eerste lijn gaan opereren van het verpleeghuis.

\section{TRANSMURALE ZORG}

Geleidelijk is het besef gegroeid dat bilateraal gedragen verantwoordelijkheid voor het welslagen van een project essentieel is. 
Het tegenwoordig in de gezondheidszorg voorgestane fenomeen van de transmurale zorg is dan ook bij voorbaat bilateraal gericht.

In de definitie van de Nationale Raad voor de Volksgezondheid (1995) wordt onder transmurale zorg verstaan: 'vormen van zorgverlening die, toegesneden op de behoefte van de veelal in de thuissituarie verblijvende patiènt met complexe zorgproblematiek, plaatsvinden op basis van samenwerking en afstemming tussen specialistische en generalistische zorgverleners, waarbij, sprake is van een gemeenschappelijke verantwoordelijkheid met expliciete deelverantwoordelijkheden'.

Deze 'nu' gewenste 'transmuraliteit' verkeert echter nog in een pril stadium.

Sinds de aanvaarding van het echelonneringsprincipe in de gezondheidszorg in 1974 heeft de gezondheidspolitiek immers voortdurend de samenwerking tussen de generalistische huisartsgeneeskunde en de specialistische geneeskunde beïnvloed; een gegeven dat tot op de dag van vandaag een wissel trekt op de ontschorting.

Men heeft zich hierdoor altijd te veel beziggehouden met de vraag 'wie' de behandeling mag verlenen in plaats van 'hoe' dit het beste zou kunnen gebeuren. De negatieve effecten van het oproepen van deze kunstmatige tegenstelling tussen eerste en tweede lijn hebben zich uiteindelijk het duidelijkst gemanifesteerd in het tekortschieten van de samenhang en continuïteit van de zorg in het transmurale circuit, gelegen tussen de respectievelijke domeinen van de huisarts én de specialist inclusief de verpleeghuisarts."

In de praktijk blijkt de prilheid van de transmurale samenwerking binnen de geneeskunde ook uit het gegeven dat met betrekking tot de medische zorg nog

70 absoluut geen sprake is van grensoverschrijdende protocollen. Bovendien wordt de transmurale samenwerking vooralsnog niet ondersteund met een meer permanente en structurele financiering. ${ }^{\text {*a.37 }}$

Desalniertemin biedt de door de overheid gewenste versterking van de thuiszorg én her onderbrengen bij de AWBZ van zowel de langdurige zorg als de zorg in verzorgingshuizen, in de roekomst aan verpleeghuizen nog meer mogelijkheden om extramuraal c.q. transmuraal te gaan opereren. De verpleeghuisarts en de huisarts zullen elkaar in de eerste lijn in ieder geval nog frequenter gaan ontmoeten. Complementariteit in plaats van concurrentie in de zorgverlening zal dan uiteindelijk bepalend zijn voor het realiseren van een succesvolle transmurale samenwerking. ${ }^{30.31}$

\section{DE SAMENWERKING TUSSEN VERPLEEGHUISARTS EN HUISARTS NADER BEKEKEN}

Ontwikkelingen in de zorgverlening kunnen tot samenwerking leiden ofwel deze als het ware afdwingen. Daarmee is de samenwerking in praktische zin echter nog nier gerealiseerd. ${ }^{3.0}$ Kennis ten aanzien van overeenkomsten en verschillen tussen de verpleeghuisgeneeskunde en de huisartsgeneeskunde is in feite onontbeerlijk voor het tot stand brengen van een betere afstemming, samenwerking en zorgvernieuwing. ${ }^{303}$ De Haan en Ribbe vergeleken in 1993 beide vakgebieden op inhoud (tabel 1), plaats in het gezondheidszorgsysteem (tabel 2), opleiding en werenschappelijk onderzoek.

Hun conclusie was dat de huisartsgeneeskunde en verpleeghuisgeneeskunde, ondanks de aanwezige professionele analogie, inhoudelijk een duidelijk eigen koers volgen. Ervan uitgaande dat inhoudelijk en functioneel een eigen plaats voor beide vakgebieden logisch is, ligt uitbreiding van de samenwerking, gezien 
TABEL 1

Vergetijking van

huisarts- en

verpleeghuis-

geneeskunde:

inhoud. van de vakgebieden

Aspect
Aard hulpvragers
Focus van de zorg

Zorgaanbod

Zorgduur

Leeftijdsverdeling

van hulpvragers

Zelfredzaamheid

van de patient

Aandoeningen

Omschrijving

vakgebied
Alle leeftijiden

Doorgaans groot

- Zelf limiterende ('alledaagse') aandoeningen

- Chronische aandoeningen

- Acute. ernstige aandoeningen

Continue. integrale en persoontijke zorg voor de gezondheid van individuen en gezinnen die zich aan de huisarts toevertrouwen

Ongeveer 40 NHG-standaarden "* zijn gereed; meerdere zijn in voorbereiding
Verplevghubgeneeskinde

Meestal ernstig gehandicapte patiènten

Het individu, opgenomen in een instelling

Medische zorg, CLSM-zorg*

Somatisch: gemiddeld 1 jaar; Psychogeriatrisch: gemiddeld 2,5 jaat

Voornamelijk bejaarden

Doorgaans klein

- Chronische aandoeningen; eindstadia

- Intercurrente aandoeningen, complicaties

- Beperkingen, handicaps

Probleemgeoriènteerde medische zorg in multi. disciplinair teamverband voor gehandicapte, in meerderheid bejaarde patiênten gezondheidsproblemen

Protocollen

Tot nu toe enkele; nieuwe in voorbereiding

" CLSM-zorg = continue, langdurige, systematische en multidisciplinaire zorg

* NHG = Nederlands Huisartsen Genootschap

Bron: Haan, M. de en M.W. Ribbe (1993). 'Huisartsgeneeskunde en verpleeghuisgeneeskunde; een vergelijking'. In: Nederlands Tijdschrift voor Geneeskunde 137, 52, pp. 2696-2701.

de geschetste ontwikkelingen in de zorg, eveneens voor de hand, mits daarbij de kern van beide disciplines als uitgangspunt wordt genomen bij de verdeling van de medische taken. ${ }^{3}$

In 1996 heeft een gezamenlijke werkgroep van de Landelijke Huisartsen Vereniging: (LHV) en de Nederlandse Vereniging van Verpleeghuisartsen (NVVA) getracht, om met het oog op de veranderingen in de ouderenzorg en uitgaande van de verschillen tussen de huisartsgeneeskunde en de verpleeghuis-geneeskunde (zie tabel 3), een handreiking op te stellen voor de samenwerking tussen huisarts en verpleeghuisarts.

De werkgroep constateert een aantal frictiepunten ten aanzien van de samenwerking." 


\begin{tabular}{|c|c|c|}
\hline Aspect & Huisartsgeneeskunde & Verpleeghuisgeneeskunde \\
\hline Praktijkgrootte & 2350 mensen & 100 mensen (standaard) \\
\hline Praktijkuitoefening & $\begin{array}{l}\text { Solist }(50 \%) \text {; in duoprak- } \\
\text { tijk }(28 \%) \text {; groepspraktijk } \\
\text { of gezamentijk centrum }(17 \%) \text { : } \\
\text { assistent-geneeskundige ( } 5 \%)\end{array}$ & $\begin{array}{l}\text { Werkaam in multidisci- } \\
\text { ptinait team in verpleeg- } \\
\text { huis }\end{array}$ \\
\hline Toeganketijkheid & Vrij & Via AWBZ"-indicatie \\
\hline $\begin{array}{l}\text { Samemwerking met andere } \\
\text { disciptines }\end{array}$ & Relatief beperkt & Vrijwel altijd (verpleging e.d.) \\
\hline Professionele organisaties & $\begin{array}{l}\text { Landelijke Huisartsen Vereni- } \\
\text { ging. Nederiands Huisartsen } \\
\text { Genootschap }\end{array}$ & $\begin{array}{l}\text { Nederlandse Vereniging van } \\
\text { Verpleeghuisartsen }\end{array}$ \\
\hline Consultatie over en weer & $\begin{array}{l}\text { Geen consultatie van ver- } \\
\text { pleeghuisartsen }\end{array}$ & $\begin{array}{l}\text { Conșultatie van huisarts } \\
\text { op verzoek }\end{array}$ \\
\hline Opleiding en registratie & $\begin{array}{l}\text { Geregeld door CHVG } \cdots \text { en } \\
\text { HVRC**" uitgevoerd door } 8 \\
\text { Universitaire Huisartsen } \\
\text { Instituten }\end{array}$ & $\begin{array}{l}\text { Geregeld door CHVG en } \\
\text { HVRC, uitgevoerd door } 2 \text { en } \\
\text { nu. } 3 \text { Universitaire } \\
\text { Verpleeghuisarts Instituten }\end{array}$ \\
\hline Aantal geregistreerden & $\begin{array}{l}\text { Ongeveer } 8500 \text {, van wie circa } \\
7000 \text { praktiserend }\end{array}$ & Ongeveer $780 \cdots \cdots$ \\
\hline
\end{tabular}

Bron: M. de Haan en M.W. Ribbe (1993), 'Huisartsgeneeskunde en verpleeghuisgeneeskunde; een vergetijking'. In: Nederlands Tijdschrift voor Geneeskunde 137, 52, pp. 2696-2701.

Daar waar huisarts en verpleeghuisarts elkaar nu in de eerste lijn ontmoeten, en dat betreft vooral de verzorgingshuizen, blijkt vaak sprake te zijn van:

- onduidelijkheid over de medische eindverantwoordelijkheid;

- problemen met betrekking tot de afbakening van elkaars territorium;

- onbegrip ten aanzien van elkaars mogelijkheden en werkwijzen

- problemen inzake de continuïteit van de zorg, inclusief de 24-uursbereikbaarheid;

- verwarring door de diversiteit in aanpak van zorgproblemen;

- onzekere en verwarrende financiële kaders.

De intensiteit van deze frictiepunten blijkt overigens sterk afhankelijk te zijn van lokale omstandigheden en bovendien wordt de samenwerking in ongunstige zin beïnvloed door de heersende onzekerheid omtrent de toekomstige ontwikkelingen (waaronder het overheidsbeleid inzake de transmuraliteit, de rol van de zorgverzekeraars, de contracteervrijheid etcetera). 
TABEL 3

Verschitlen tusser huisarts en verpleeghuisarts

Relatie arts-patiènt

Bekendheid met de patient

Deskundigheid

Zorgvertening

Teamgerichtheid
Brede ongeselecteerde doelgroep

Huisartsenzorg is doorgaans alleen mogetijk indien er bij de patiènt nog enige zelfredzaamheid aanwerig is. Patiènt heeft eigen verantwoordetijkheid t.a.v. de zorgvraag.

8 ij bestissingen van de huisarts wordt rekening gehouden met het systeem rondom de patiènt (famitie/ mantelzorg)

Het eerste en de volgende contacten komen tot stand op initiatief van de patient zelf.

Kent patient wat betreft voorgeschiedenis, wijze van reageren, etc. Hij is vertrouwd met de patient en diens omgeving.

Generalist

Patiènt- en probleemgeoriênteerd, rekening houdend met de sociale omgeving (mantelzorg is van groot belang) Intermitterende zorg, enikelvoudige en meervoudige zorg.

Gewend te denken vanuit zorgsystemen (familie en mantelzorg).

Overwegend solistisch ingesteld.
Geselecteerde doelgroep met een samengestelde zorgviaag. veelal ouderen

Patient is minder assertief t.a.v. de eigen zorgvraag

Bij bestissingen van de verpleeghuisarts wordt rekening gehouden met de sociale context (familie en andere bewoners) Het eerste en de volgende contacten komen tot stand op initiatief van de verpleeghuisarts en ten gevolge van observatie door de verpleging/verzorging

Kan blanco beginnen met vergaren van informatie, hetgeen nieuwe inzichten kan geven, maar ook als een nadeel kan worden ervaren.

Generatist voor een geselecteerde doelgroep. Specialistisch op de gebieden (psycho-) geriatrie, revalidatie, reactivering en samengestelde zorgverlening.

Individuele zorg. rekening houdend met groepsgewijs samenleven in eer instelling.

Chronische, veelal' dagelijkse, samengestelde rorg.

Gewend te denken vanuit professionele systemen (instelling).

Werkt in principe altijd vanuit een multidisci. plinair team, verantwoordelijkheidsrelaties. zijn verticaal, in die zin dat de verpleeghuisarts verantwoordelijk is voor de regie en de inhoud van het totale zorgptan. 


\begin{tabular}{|c|c|c|}
\hline $\begin{array}{l}\text { Inroepen van mensen/ } \\
\text { middelen }\end{array}$ & $\begin{array}{l}\text { Deskundigheid is op afroep } \\
\text { beschikbaar. } \\
\text { De huisarts dient samen } \\
\text { te werken met autonome } \\
\text { professionals, w.o de wijk-. } \\
\text { en gezinszorg (waarbij in de } \\
\text { chronische zorg tegenwoordig } \\
\text { ook zoveet mogelijk o.b.v. } \\
\text { ten gezamenlijk zorgplan, } \\
\text { dat bij de patient thuis } \\
\text { aanwezig is, gewerkt wordt). } \\
\text { De aansturing is lastiger } \\
\text { vanwege de zelfstandigheid } \\
\text { van deze Thulptroepen'. }\end{array}$ & $\begin{array}{l}\text { Deskundigheid andere dis- } \\
\text { ciplines gemakbetjker } \\
\text { beschikbaar } \\
\text { Vast samengesteld team } \\
\text { dat werkt aan de hand } \\
\text { van een geintegreend } \\
\text { zorgplan. }\end{array}$ \\
\hline $\begin{array}{l}\text { Afstemming (overleg/ } \\
\text { vergadering) }\end{array}$ & $\begin{array}{l}\text { Overteg en vergadering niet } \\
\text { structureet ingebed in de } \\
\text { praktijkvoering, vanwege } \\
\text { een niet expliciete hono- } \\
\text { rering en uit oogpunt van } \\
\text { time-management. }\end{array}$ & $\begin{array}{l}\text { Overieg en vergadering } \\
\text { maken expliciet onderdeel } \\
\text { uit van de functie. Werkt } \\
\text { aan de hand van een zorg. } \\
\text { plan en met een zorg- } \\
\text { dossier. }\end{array}$ \\
\hline
\end{tabular}

Vorm van dienstverband Vrije beroeper.

In loondienst.

Continuiteit van zorg 24-uurs beschilbaarheid van

24-uurs beschikbaarheid de huisarts door middel van voor zorgvragen binnen de waarneemregeling. Medische gegevens niet continu beschikbaar.

\section{UITGANGSPUNT IS DE GEMEENSCHAPPELIJKE VERANTWOORDELIJKHEID VOOR DE ZORGBEHOEVENDE PATIËNT}

Ervan uitgaande dat de positie van beide beroepsgroepen goed verankerd is in de gezondheidszorg, zou het waarborgen van de continuïteit in de zorgverlening voor fors zorgbehoevende patiènten, die zo lang mogelijk hun zelfstandigheid willen blijven behouden, voor zowel de huisarts als de verpleeghuisarts uitgangspunt dienen te zijn. Deze patiënten dienen de zorg te krijgen, die ze willen en nodig hebben en dit hoeft heden ten dage dus niet рег definitie intramuraal te gebeuren. Een en ander zal steeds meer in de thuissituatie gaan geschieden."

De huisarts en de verpleeghuisarts kunnen, door een goede onderlinge samenwerking alsook door cen doelmatige afstemming met de andere hulpverleners in de thuiszorg, een belangrijke bijdrage leveren aan her realiseren van de beste zorg voor elke zorgbehoevende patiënt. Hun afzonderlijke deskundigheden dienen daarbij complementair in plaats van concurrerend te zijn. Dan is sprake van een 'gedeelde' zorg in plaats van een 'dubbele' zorg."

Uitgaande van dit samenwerkingsprincipe dient uiteraard in eerste instantie overeenstemming te bestaan over de omschrijving van de verschillende zorgvormen. De hierboven vermelde werkgroep van de LHV/NVVA heeft getracht hierin duidelijkheid te scheppen (LHV/NVVA 1996). 
Zij onderscheidt drie zorgvormen:

1. enkelvoudige zorg. Dit is zorg, verleend door één beroepsbeoefenaar;

2. meervoudige zorg. Dit is zorgverlening door verschillende, zelfstandige beroepsbeoefenaren die de afstemming onderling regelen, zonder duidelijke hiërarchie in de regievoering;

3. samengestelde zorg. Zorg, die verleend wordt door een medisch, paramedisch en verpleegkundig team, dat een integrale behandeling, verpleging en begeleiding biedt, op grond van een met de patiènt en diens familie overeengekomen zorgplan. De uitvoering wordt bewaakt door een zorgcoördinator en de medische eindverantwoordelijkheid is goed vastgelegd.

In de verplecghuiswereld is al veel ervaring opgedaan met de verlening van samengestelde zorg. Ook in de thuiszorg is werken op basis van één gezamenlijk zorgplan meer en meer gemeengoed aan het worden.

In het nog vage gebied tussen huisartsengeneeskunde en verpleeghuisgeneeskunde zal in de toekomst echter sprake zijn van een toenemende vraag naar samengestelde zorg voor patiënten die nog in de thuissituatie verblijven. Samenwerking tussen huisarts en verpleeghuisarts kan hier verder gestalte krijgen, indien men gezamenlijk uitgaat van een aantal wezenlijke uitgangspunten, namelijk:

- her belang om de pariènt zo lang mogelijk in zijn thuissituatic te (laten) verblijven:

- er moeten voldoende mogelijkheden zijn om de zorgverlening ook daadwerkelijk thuis te realiseren;

- de draaglast van de zorgverlening mag de draagkracht niet te boven gaan, met name ook in relatie tot de mantelzorg;

- de flexibiliteit en de continuïteit van de zorgverlening moeten verzekerd zijn;

- er moet helderheid bestaan met betrekking tot het moment waarop een eventueel gewenste doorstroming van extramurale naar semimurale of intramurale zorgverlening gerealiseerd dient te worden.

Bị de ontwikkeling van verdere samenwerking zou men, naast de door de L.HV/NVVA-werkgroep genoemde frictiepunten, in eerste instantie uit moeten gaan van de knelpunten c.q. beperkingen die huisartsen en verpleeghuisartsen nu in de dagelijkse praktijk ervaren. Dit bij het samen gestalte geven aan de zorg voor ouderen en chronisch zieken, die nog in de thuissituatie of in het verzorgingshuis verblijven.

Knelpunten die hier vaak genoemd worden en die ook beschreven zijn, omvatten: ${ }^{i+1}$ s

- een gebrek aan kennis en vaardigheden en aan inzicht in de gewenste taakinvulling;

- gebrek aan zicht op de actualiteit van de zorgvraag;

- de beschikbaarheid en mogelijkheden van de mantelzorg;

- de wederzijdse afstemming met andere hulpverleners buiten het direct medische circuit;

- de onbekendheid met elkaars functioneren en mogelijkheden;

- de overlappende werkgebieden;

- de onbekendheid met de mogelijkheden van het totale zorgcircuit; 
- het niet aanwezig zijn van een door samenwerkingspartijen gedeelde zorgvisie;

- de motivatie tot samenwerken; wederzijdse vooroordelen;

- de gebrekkige communicarie;

- de beperkte tijd die überhaupt beschikbaar is voor samenwerkingscontacten en doelmatige overlegvormen, met andere woorden: de angst voor een verdere toename van de werkdruk;

- de gebrekkige coördinatie en continuïteit;

- de onduidelijke en onzekere financiering;

- de onduidelijke en steeds veranderende regelgeving in de thuiszorg.

Bij het verbeteren van de samenwerking tussen huisartsen en andere hulpverleners in de gezondheidszorg stuit men bovendien vaak op het probleem dat huisartsen niet goed aanspreekbaar zijn als groep en op de interne communicatie binnen die groep. Het ontbreekt de huisartsen aan een duidelijk aanspreekbare persoon als vertegenwoordiger, en zij zijn niet gebonden aan de door de beroepsvereniging gemaakte afspraken en overeenkomsten. Dat bemoeilijkt het maken van afspraken op groepsniveau.

\section{MODELLEN VAN SAMENWERKING}

Inmiddels is een aantal modellen met betrekking tot de samenwerking tussen huisarts en verplecghuisarts bekend."

\section{De consultatiefunctie van verpleeghuisartsen}

76 De consultatiefunctie van verpleeghuisartsen is hierboven al beschreven. De verpleeghuisarts kan hierbij de huisarts en andere eerstelijnshulpverleners adviserend ondersteunen, met als doel de patiën langer in diens eigen woonomgeving te kunnen handhaven. De huisarts blijft eindverantwoordelijk voor de totale behandeling. In feite krijgt deze functie van origine al gestalte op de verpleeghuisdagbehandeling, waar de eindverantwoordelijkheid voor de behandeling ook in handen van de huisarts blijft.

Maar ook ten behoeve van patiënten in de thuissituatie en in het verzorgingshuis kan deze consultatie, al dan niet middels substitutie, uitgeoefend worden.

Bij de advisering vanuit het verpleeghuis kan de verpleeghuisarts overigens de totale deskundigheid van het verpleeghuis inzetten. Zo kan her bij consultatie gaan om een eenmalige screening, om adviezen over hulpmiddelen en woningaanpassingen, om medicatie- of dieetadviezen, om deskundigheidsbevordering etcetera.

\section{De deelbẹanandeling}

Bij de deelbehandeling voert de verpleeghuisarts zijn ạdvies aangaande de medische zorg en behandeling zelf uit. Hij is dan ook verantwoordelijk voor dat deel van de zorgverlening. De huisarts blijft de eindverantwoordelijkheid voor de totale behandeling dragen.

Een goed voorbeeld van dit samenwerkingsmodel is de huisarts die de verpleeghuisarts vraagt om de integrale decubitusbehandeling van een thuis- of in het verzorgingshuis wonende patiēnt over te nemen. De verpleeghuișarts voert deze behandeling uit, terwijl hij regelmatig verslag doet aan de huisarts en ook een goede samenwerking met de andere aanwezige hulpverleners nastreeft. 
De volledige behandeling wordt overgedragen aan de verplecghuisarts, die vervolgens een 24-uurszorg moet garanderen in afstemming met de andere aanwezige hulpverleners.

Als voorbeeld hiervan dienen sommige substitutieprojecten in verzorgingshuizen, waarin de medische zorg voor de substitutiedeelnemers volledig overgedragen is aan de verplecghuisarts.

\section{Consultatie van de huisarts}

In dit model consulteert de verpleeghuisarts de huisarts ten behoeve van de behandeling van in het verplecghuis opgenomen patiënten.

Op dit moment wordt de huisarts slechts incidenteel betrokken bij de behandeling van opgenomen verpleeghuispatiënten. Dit gebeurt meestal in die situaties waarin sprake is van flinke problemen met betrekking tot de verwachtingen of de concrete uitvoering van de zorgverlening aan de opgenomen patiènt en/of bij problemen met diens verwanten.

Incidenteel speelt de consultatie van de huisarts ook een rol bij problemen tussen de opgenomen verpleeghuispatiënt en diens eigen familieleden.

Welk model van samenwerking gekozen wordt, is afhankelijk van de locoregionale situatic, van het niveau tot waarop afspraken gemaakt kunnen worden en zeker ook van de aard en reikwijdte van de zorgvraag of de patièntenproblematick.

Een zekere dynamiek en flexibiliteit in de aard van de samenwerking mag en moet daarbij aanwezig blijven, mede afhankelijk van de zorgvraag van de individuele patiënt.

In de praktijk zal dit waarschijnlijk betekenen dat buiten de muren van het verpleeghuis de huisarts eindverantwoordelijk is en blijft voor de medische zorg in de thuissituatie.

In het verzorgingshuis en wellicht ook in de, in de toekomst steeds meer voorkomende, woonzorgcomplexen kan mogelijk een overgangsgebied ontstaan, waarbij ook de verpleeghuisarts de eindverantwoordelijkheid kan dragen.

Uiteraard hebben de beschreven modellen ook implicaties voor de andere hulpverleners die in de totale zorg ten behoeve van de zorgvragers actief zijn. De zorg van de huisarts en verpleeghuisarts is immers slechts een deel van de totale zorg die verleend wordt.

Met het oog op het voorgaande is het begrijpelijk dat op dit moment zowel huisartsen als verpleeghuisartsen ervan overtuigd zijn dat een gedegen heroriëntatie op hun kerntaken inzake de chronische zorgverlening en de ouderenzorg noodzakelijk is. ${ }^{1.1 .1730+10}$ 


\section{LITERATUUR}

1. Heuvel WJA vd. De uitdaging van een verouderende samenleving en de lansen voor her beleid. Het Ziekenhuis 1994: 24: 460-1.

2. RIVM. Volksgezondheid Toekomst Verkenning De gezondheidstocarand van de Nederlandse bevolking in de periode 1950-2010. Ruwaand D., Kramers, PGN (eindred.) Den Haag Sdu Virgeverii, 1993.

3. NRV. Pyychogeriatrier marg voor dementerenden. Deel 3: advies. Zoetermeer. NRV, 1994.

4. Brouwer W. Het Scenario Geriatrie. Patient Care 1988; 15: 22-7,

5. Verplecghuisuorg in perspectirf, Beleidsnota sectie Verplecghumen NZR. Utrecht: NZR. 1989.

6. Nota vraaggescuarde verplecghuisong. Handreiking voor een regionale posiricbepaling, Rapportage van de arrategiegroep verplecghuinen. Utrechrs NVV̌, 1995.

7. Beleidisoetsingakader sector verplecgluisen. Utrecht: NVVz, 1995/1996.

8. Commisuie Moderniscring Ouderenzorg (commissic-Welschen). Nota Ouderenzorg met toekomst. Rijwijle VWS, 1994.

9. Duijn J. Thuistorg, cen inventarisati. Utrecht: Stichting O $\&$ O, 1988.

10. Elberse WR Langerak NH en Schrijven AIR. Huisarts - Thuisarts. Utrecht: Vakgrocp Algemene Gezondheidszorg RUU, I9א8

I1. H.HV, De positie van de huisurs in de toekomst. Utreche L.HV, 1987. (Aangepast in 1995)

12. Commissie Modernisering Curatieve zorg (commissie-Biedheuvel). Nota Gedeclde zorg: betere zorg. Zoetermeeri Hageman BV, 1994.

13. Schade E. De rol van de huisars in de thuisworg, In: Handbock Thuistorg. Schrijvers AJP e.a. (red.) Uereche De Tijdstroom, 1997.

14. Bos GAM van den. Ondernock naar de gevolgen van chronische aandoeningen in de gerondheidsarge Kwaliteit van zorg. Tijdschrift voor Sociale Gezondheidszorg (TSG); 1991:69: 237-41.

78 15. Kessenes AW. Thuiszorg; waar praten we over? Tijdschrif SDO 1988:2 (11); 6-7.

16. Provinciale Raad voor de Volksgezondheid Noord-Brabant. Noritie Thuistorg.(1988),

17. Schade E, Dokter HACh. Thuiszorg. Tussen idee en werkelijkheid. Nederlands Tijdschr Geneeskd 1995:139: 2444-8

18. Schols JMGA, Wierik te JMI. Verplecghuiszorg, buiten de muren. Dagbehandeling, consultatie en substitutieprojecten. Nederlands. Tijdschr Geneeskd 1993: 137: 2717-22.

19. Schols IMGA. Samenwerking huisarts en verplecghuisarts. Praktijkmanagement voor de huisarts 1989 : $(7): 18-23$

20. Ziekenfondsraad (ZFR). Besluit Dagbehandeling in ecn verplecginrichting. Amstelveen: ZFR, 1977.

21. Nies HL.GR. Daghehandeling? Een russentijdse balans van dagbehandeling in verplecghuizen. Tijdschr Gerontol Geriatr 1986; 17: 25-32.

22. Ziekenfondsraad (ZFR). Consultatieve functie verplecgintichtingen. Nr. 320. Amstelveen: ZFR. 1986.

23. Ziekenfondsraad (ZFR). Subsidiebesluit Substitutie verplecghuiszorg. Nr. 107. Amstelveen: ZFR. 1988.

24. Schols JMGA. Vanuit de praktijk. Substitutie verplecghuiszorg. Vox Hospitii 1991: 15 (4): 96-9.

25. Laffrée CRJ, Verdenius W. Substitutie zonder betrokkenheid tot mislukken gedoemd. Medisch Contact 1989: 44: i 14-8.

26. Beet MFJM de, Fahrenfort M. Verpleeghuiszorg buiten de muren. De rol van de huisarca. Medisch. Contact 1993; 48: 597-9.

27. Blanken J. 35 substituticprojecten getvalueerd. "Versnippering AWBZ-geiden moet voorkomen worden". Zorg en Ondernemen 1993: 6: 20-4.

28. Wierik MJM re, Dijk P van, Stomph ECA. Hollands L. Substituticprojecten verplecghuiszorg, Een onderzock naar zorgrwaarte en kwaliteirsaspecten van zorg in verplecg-en vernorginghuizen. Dwingeloo: KAVANAH, 1994.

29. Linschoten CP van, Meyboom-de Jong B, Moorer. R. Wolffensperger EW. De gevolgen voor de huisarts van de substitutie van verplecghuistorg. Huisarts Wet 1996; 26: 162-4. 
30. Katz R. Oplossing cranamurale mysterie stapje naderboj. Het Zickenhuis 1996: 26: 34-5.

31. Wiefferink CH. Dukken-van Emden DM. Institutionalisering van rorgvernieuwingsprojecten. Hoe vergaat het aogvernieuwingen op de lange termijn? Medisch Contact 1996; 51: 644-6.

32. Asumann PEMTh. Bouwens FGM. Timmermans JPA. Samenwerken gast niet vanzdf. Wat men vindt en wat men wenst. Medisch Contact 1996; 51: 637-8.

33. Peters C, Bergh JHAM van den Scholten GRM. Vijver FJM van den. Regionale samenwerking russen huisarsen en spocialisten. Opvattingen en uitgangspunten. Medisch Contact 1996: 51: 639-41.

34. Haan M de, Ribbe MW. Huisarogenecskunde en verplecghaiggeneeskundes een vergelijking. Ned Tijduche Genecskd 1993: 137: 2696-701

35. LHV/NVVA. Handreiking voor de samenwerking huisarb-verpleeghuisars. Rapportage van de gramenlijke werkgrocp van de LHV an de NVVA. Utreche: LHVINVVA, 1996

36. Schols JMGA. Theunisen NJS, Botst V. Sinnema ME. Verplecghuisoorg in bewoging. Een imventariserend overzicht van vij substituricprojecten verplecghuisnorg. Tijdschr Gerontel Geriatr 1995; 26: 10-5.

37. Hoefnagels KL.]. Samenwerking tusen huisars en specialise. Medisch Contact 1996: 51: 763.

38. Sprecuwenberg C. Zorgvernicuwing voor chronisch zieken. Medisch Contact 1994: 49:1591-2

39. Sprecuwenberg C (Net) werken voor chronisch sicken. Inaugurale rode. Ripkuniveniteir Limburg. Masstricht: 1994.

40. Dos E van det. De positic van de huisars. Omzien en vooruitzien. Medisch Contact 1996; 51: 687-8.

41. Diermen K van. Huijuman R. Huisarsen in de transmurale hoofdrol.. Medisch Contact 1996: 51: 1347-9.

42. Kersten TJJMT. De invloed van huisartsen in de rweede lijn. Procfichrift. RU. Utreche: 1991.

43. Idenburg P. Transmuralisering en nerwerkvorming, een tussenstand. Zorgvisie 1996! (4) 7.10. 


\section{CONTACTEN TUSSEN VERPLEEGHUISARTS EN HUISARTS \\ FREQUENTIE, AARD EN INHOUD}

J.M.G.A. Schols, R.T.C.M. Koopmans, J.P.M. Diederiks, F. Sturmans,

H.F.J.M. Crebolder 


\section{SAMENVATTING}

In 1996 vond in de regio Oosterhout/Dongemond, het verzorgingsgebied van Streekverpleeghuis de Riethorst in Geertruidenberg, een inventariserend onderzoek plaats naar de contacten tussen verpleeghuisartsen en huisartsen. Door de verpleeghuisartsen werden alle contacten $(n=363)$ geregistreerd, die zij in dat jaar met de huisartsen hadden over nieuwe patiënten, bij opname en na opname in 1996, in respectievelijk het verpleeghuis, op de dagbehandeling en in de substitutieprojecten, alsmede de contacten aangaande de consultatiefunctie en de nietpatiëntgebonden aangelegenheden. Registratie geschiedde op een voorgestructureerd standaardformulier. In de contacten bleek vooral sprake te zijn van éénrichtingsverkeer. In $91 \%$ van de contacten ging het initiatief uit van de verpleeghuisarts. Ongeveer tweederde van de contactredenen had betrekking op 'patiëntenoverdracht'. Verder onderzoek is noodzakelijk om bredere en meer gedetailleerde informatie te verkrijgen omtrent het actuele niveau van samenwerking tussen huisarts en verpleeghuisarts en omtrent de omstandigheden waaronder deze samenwerking geïntensiveerd kan worden.

\section{SUMMARY}

Contacts between the nursing home physician and the general practitioner (GP): frequency, character and contents

An inventory was made on actual contacts, in 1996, between nursing home physicians and general practitioners (GP's) in the care-region of the Geertruidenberg nursing home, 'de Riethorst'. Registration of all contacts $(n=363)$ between

82 the nursing home physicians and the GP's, on newly admitted patients in the nursing home, in nursing home day care, in nursing home substitute care and with respect to consultation and other matters, was carried out. The registration on a standard form was done by the nursing home physicians. The results indicate that the contacts between nursing home physicians and GP's occurred mainly unidirectionally from nursing home physician to GP (9I\%). In about $2 / 3$ of the cases the reasons for contact were associated with patient transitions. With regard to future developments in the health care services further investigations are necessary to gather more detailed information on the actual level of cooperation between the nursing home physician and the GP and on the conditions which are required to increase this level of cooperation. 


\section{INLEIDING}

Sinds eind jaren tachtig heeft de extramurale verplecghuiszorg steeds meer vorm gekregen.' Ontwikkelingen in de ouderenzorg, waar sprake is van een toenemend aantal zorgbehoeftige ouderen, voor wie in een instelling geen plaats beschikbaar is of die zorgverlening in de eigen omgeving prefereren, hebben hieraan bijgedragen. De consultaticfuncrie van het verpleeghuis en de vooralsnog projectsgewijze substitutie van verpleeghuiszorg zijn op dit moment de pijlers waarop de 'outreaching' activiteiten van het verpleeghuis rusten.' Door middel van de consultatiefunctie kunnen de verpleeghuisarts en/of andere hulpverleners uit het verpleeghuis adviserend optreden ten behoeve van patiènten thuis en in het verzorgingshuis. Bij substitutie wordt op projectbasis aan patiënten, die cen indicarie hebben voor opname in een verpleeghuis, thuis of in het verzorgingshuis extra ondersteuning geboden vanuit het verplecghuis."

De extramurale zorg die vanuit het verpleeghuis wordt verleend, is aanvullend aan de reeds aanwezige zorg. Dit betekent dat verpleeghuismedewerkers hun specifieke expertise gaan inbrengen in de eerstelijnszorgverlening, die normaliter voorbehouden is aan onder anderen de huisarts en de thuiszorg. De huisarts wordt de laatste jaren dan ook, zeker in verzorgingshuizen, vaker geconfronteerd met een ter plaatse 'meekijkende en meedenkende' verpleeghuisarts, terwijl in het verleden hun onderlinge contact voornamelijk in de verwijzende sfeer lag.

Nu de extramurale verpleeghuiszorg min of meer ingeburgerd raakt, is het zinvol om na te gaan hoe het contact tussen huisarts en verplecghuisarts op dit moment gestalte krijgt. Is er naast de traditionele verwijscontacten inmiddels ook sprake van contacten over de te verlenen zorg? Met andere woorden, is het merkbaar dat ze regelmatig samen bij de hulp aan zorgvragers in het verpleeghuis en in de eerstelijn (inclusief het verzorgingshuis) betrokken zijn? Of is hun bemoeienis met deze zorgvragers nog veelal separaat van aard?

Deze vragen en het gegeven dat de kennis over de samenwerking tussen huisarts en verpleeghuisarts in het algemeen onduidelijk en versnipperd is, hebben ons ertoe aangezet om in 1996, vanuit het streekverpleeghuis de Riethorst in Geertruidenberg, een inventariserend onderzoek te verrichten aangaande de contacten tussen huisarts en verpleeghuisarts. Verpleeghuis de Riethorst is een middelgroot gecombineerd verpleeghuis met 105 somatische en 60 psychogeriatrische bedden. Er is een dagbehandeling met tien somatische en tien psychogeriatrische plaatsen. Tevens voert het verpleeghuis cen viertal substitutieprojecten uit in verzorgingshuizen, waarin voornamelijk groepsverzorging voor dementerende bewoners en incidentele meerzorg voor bewoners met somatische aandoeningen wordt geboden (in totaal nemen 88 bewoners hieraan deel). Verder ontplooit het verpleeghuis adviserende activiteiten in het kader van de consultatiefunctie.

De vraagstellingen voor het onderhavige onderzoek waren:

- Wat was in 1996 de frequentie van contacten tussen verplecghuisartsen en huisartsen?

- Wie nam het initiatief en via welke communicatiekanalen verliep het contact?

- Wat waren de contactredenen voor respectievelijk de huisarts en de verpleeghuisarts, gerelateerd aan de intra-, semi- en extramurale zorgverlening van het verpleeghuis? 


\section{METHODE}

In de periode 1-1-1996 tot en met 31-12-1996 werden door de verpleeghuisartsen $(n=5)$ de volgende contacten tussen henzelf en de huisartsen in het verzorgingsgebied van het verpleeghuis $(\mathrm{n}=37)$ geregistreerd:

- alle contacten over in dat jaar voor het eerst opgenomen patiënten in het verpleeghuis, op de dagbehandeling en in de substitutieprojecten. Inbegrepen werden alle contacten, die in 1996 over nieuwe patiënten plaatsvonden vóór hun opname, tijdens hun opname en bij hun eventueel ontslag/overlijden;

- alle contacten inzake de consultatiefunctie;

- alle contacten over niet-patiëntgebonden zaken.

Ten behoeve van elk contact werd een apart registratieformulier ingevuld met inachtneming van de volgende afspraak. Voor alle in de contacten ter sprake komende patiènten, dus ook als dit er meerdere zouden zijn, zou een apart formulier ingevuld worden, waarbij aan elke patiënt een eigen identificatienummer werd toegekend. Door het gebruik van deze patiënt-identificatie zou het mogelijk zijn om het aantal contacten per patiënt te berekenen.

Het contactregistratieformulier was special voor dit onderzoek opgesteld en beproefd in een pilot-onderzoek, waarin elke verpleeghuisarts tien contacten met huisartsen registreerde. Om in het definitieve onderzoek de variatie tussen de invullers zoveel mogelijk te verkleinen, werd nadere instructie gegeven omtrent de wijze van invullen van de formulieren. Vervolgens vond hierop een maandelijkse controle plaats aan de hand van de aangeleverde registraties. De volgende gegevens

84 werden door de verpleeghuisartsen, direct na elk contact, met behulp van het registratieformulier vastgelegd:

- de datum van het contact en het gebruikte communicatiekanaal (categorieën: persoonlijk, uitsluitend telefonisch, uitsluitend schriftelijk, telefonisch én schriftelijk en anders);

- de initiatiefnemer tot het contact (de huisarts of de verpleeghuisarts);

- de aanleiding voor het contact: over een patiënt of over andere zaken;

- de reden(en) voor de huisarts om contact op te nemen; (tien voorgestructureerde items, zoals 'gemotiveerde aanmelding voor verpleeghuis, dagbehandeling of substitutie', 'informatie/overleg bij opname', 'tijdens opname', 'verzoek om consultatieve advisering'). Indien het om een consultatief verzoek ging, was er de mogelijkheid om de aard van dit verzoek nader aan te geven in een extra rubriek 'omschrijving consultvraag', met 11 voorgestructureerde items. Per contact konden meerdere redenen aangegeven worden;

- de reden(en) voor de verpleeghuisarts om contact op te nemen; (opnieuw tien voorgestructureerde items). Per contact konden meerdere redenen aangegeven worden.

\section{RESULTATEN}

Contactfrequentie, contactinitiatief en communicatiekanaal

Er werden in 1996, op de afgesproken wijze, 363 contacten geregistreerd tussen verpleeghuisarts en huisarts. Hiervan gingen er 359 over pariënten; de overige vier contacten hadden betrekking op niet-patięntgebonden aangelegenheden, namelijk over de mogelijkheden van de verpleeghuisafdeling ergotherapie, de deelname van de verplecghuisartsen aan het lokale farmacotherapie-overleg van 
de huisartsen, de organisatie van een evaluatiebijeenkomst inzake de substituticprojecten en over de verpleeghuiservaringen met een bepaald subcutaan infusiesysteem. Uit rabel 1 is de verdeling van de contacten af re leiden. In de 359 contacten over patiëntenaangelegenheden betrof het steeds individucle patiènten. De verpleeghuisarts nam in de meeste gevallen het initiatief tot het contact (91\%). Slechts in 33 gevallen lag het initiatief tot het contact bij de huisarts. Van de huisartsen in het verzorgingsgebied namen er 14 één keer contact op met een verpleeghuisarts, vijf rwee keer en drie drie keer; 15 huisartsen hadden in 1996 geen contact met een verplecghuisarts. Er was slechts heel weinig persoonlijk ('face to face') contact $(1,7 \%)$.

Ten aanzien van pariënten in het verpleeghuis vond ongeveer de helft van de contacten telefonisch plaats, eenderde telefonisch en schriftelijk en de rest schriftelijk. Bij de dagbehandeling geschiedde het contact voor de helft telefonisch en voor de helft schriftelijk. Het merendeel van de contacten in het kader van de substitutie verliep schriftelijk, terwijl de consultaties daarentegen meestal telefonisch plaatsvonden.

In totaal betroffen de contacten 250 verschillende nieuwe patiēnten (tabel 2). De gemiddelde contactfrequentie per pariènt was 1,4 .

In 1996 werden in totaal 336 patiënten door het verpleeghuis nieuw in behandeling genomen (207 in het verplecghuis, 57 op de dagbehandeling, 55 in de substitutieprojecten en 17 patiënten in het kader van de consultatiefunctie). Dit betekent dat er over 86 van de in totaal 336 patiënten, waarmee het verpleeghuis in 1996 bemoeienis kreeg, geen contact tussen de huisarts en de verpleeghuisarts bestond.

De contacten over patiënten betroffen in totaal tweemaal zo vaak. somatische als psychogeriatrische patiënten (tabel 2). Gezien de opzet van de substitutieprojecten ging het daar met name over psychogeriatrische patiènten.

\section{Contactredenen voor de huisarts}

Aan de 33 door huisartsen geïnitieerde contacten bleken in totaal 38 redenen ten grondslag te liggen. In tien gevallen ging het om patiënten die in het verpleeghuis opgenomen werden; tien maal betrof het nieuwe dagbehandelingspatiënten en 18 maal waren er redenen in het kader van de consultatiefunctie aanwezig.

Voor de huisartsen waren er geen redenen om contact op te nemen met betrekking tot aan de substitutieprojecten deelnemende patiënten. Het contact in het kader van de kliniek en de dagbehandeling betrof vooral 'informatie-uitwisseling voor en direct na opname'. Ten aanzien van de consultatiefunctie was er zes maal een verzoek om een éénmalige integrale screening van een patiënt thuis of in het verzorgingshuis. Twaalf maal betrof het een eenmalig verzoek om gerichte advisering ten behoeve van patiënten in de eerstelijn. Deze verzoeken waren over het algemeen meervoudig van aard. Hierbij werd onder andere advies gevraagd omtrent de gewenste verblijfplaats van de pariënt (vier maal), over dieet of medicatie (zeven maal), decubitusbehandeling (drie maal), raadpleging van medisch specialisten of interventie van paramedici (11 maal) en specifieke technieken, kunst- en hulpmiddelen en woningaanpassingen (tien maal).

\section{Contactredenen voor de verpleeghuisarts}

In 330 van de 363 contacten lag het initiatief bij de verpleeghuisarts. De 


\section{TABEL I}

Aantal contacten tussen verpleeghuisarts en huisarts in 1996 . naar communicatiekanaal en initiatiefnemer: betreffende nieuw opgenomen patiēnten in het verpleeghuis, op de dagbehandeling en in de substitutieprojecten. alsmede van de consultaties en de nietpatiêntgebonden

aangelegenheden

Uitsluitend schriftelijk

$\begin{array}{llllll}\text { Huisarts } & 1 & - & - & - & 1 \\ \text { Verpleeghuisarts } & 2 & 1 & 2 & - & 5\end{array}$

Uitsluitend telefonisch

$\begin{array}{lrrrrrr}\text { Huisarts } & 6 & 7 & & 14 & 2 & 29 \\ \text { Verpleeghuisarts } & 108 & 26 & 4 & 9 & 2 & 149\end{array}$

Huisarts - $20 \quad+2$

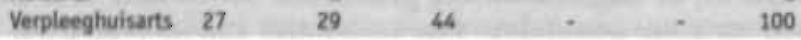

Telefonisch en schriftelijk

\begin{tabular}{|lrrrrrr|} 
& $\begin{array}{l}\text { Huisarts } \\
\text { Verpleeghuisarts }\end{array}$ & 70 & 4 & 2 & 1 & 1 \\
\hline Totaal aantal contacten & 214 & 69 & 52 & 24 & 4 & 363 \\
\hline
\end{tabular}

Aantal nieuwe patiēnten
Aantal patiënten waarover
contact tussen huisarts en
verpleeghuisarts plaatsvond

Aard van de zorg

- Somatiek

- Psychogeriatrie

Gemiddeld aantal contacten/patiènt
143

Verpleeg.

huis Dagbe- Substi- Consultatie-

(klimiek) handeling tutie functie Totoal

207

57

55

17

336

43

43

47

17

250

113

30

13

9

9
38

16

168

30

1,5
1,6

1,1

1,4

1,4

\section{TABEL ?}

Aantal nieuwe patiēnten in 1996 in de Riethorst te Geertruidẹnberg: alsmede enkele: gegevens over die nieuwe patiènten waarover in 1996 contacten tussen verpleeghuisarts en huisarts hebben plaatsgevonder $(n=250)$

verdeling van deze contacten over de vijf verpleeghuisartsen was respectievelijk $127,84,50,43 \mathrm{en} 26$, afhankelijk van onder andere het aantal en de aard van de afdelingen waarvoor zij medisch verantwoordelijk waren en van de omvang van hun dienstverband, casu quo de mate van aanwezigheid.

In tabel 3 zijn de contactredenen voor de verpleeghuisarts weergegeven. Totaal werden in 330 contacten 338 contactredenen geregistreerd.

In $31 \%$ van de gevallen $(n=104)$ betrof het vragen aan de huisarts om nadere, specifieke (medische) gegevens bij opname van een patiènt in het verpleeghuis; 24 maal vragen over patiënten, die reeds eerder in 1996 in het verpleeghuis opgenomen waren. In 77 gevallen was de contactreden het verschaffen van ontslaginformatic (inclusief overlijden) over eerder in het onderzoeksjaar opgenomen patiènten. 
TABEL 3

Redenen voor de verpleeghuisarts om contact met de huisarts op te nemen in 1996, betreffende nieuwe patienten in het verpleeghuis, op de dagbehandeling en in de substitutieprojecten, alsmede in het kader van de consultatiefunctie

(338 redenen in 330 contacten) Verzoek om nadere/specifieke
informatie over een op te nemen patiènt

Verzoek om nadere/specifieke informatie over een met dag. behandeling startende patient

Overleg over een eerder in 1996 opgenomen patient

Overleg over een eerder in 1996 met dagbehandeling gestarte patiènt

Verzoek om nadere/specifieke informatie over een aangemelde substitutiepatient

Dverleg over deelnemende patient die eerder in 1996 was gaan participeren in een substitutieproject

Overleg/rapportage over uitslag screeningsonderzoek van een nieuwe patiènt

Overleg/overdracht/rapportage over patiēnt die na opname in 1996 weer ontslagen wordt (inclusief overtijden)

Overleg/overdracht/rapportage over dagbehandelingspatiént die na start in 1996, stopt met dagbehandeting

Overleg/advisering/rapportage m.b.t. consultatieve vraag. van huisarts

Overige

Totaal
Verpleeghuis Dog. Consultatie: (kliniek) behondeling Substitutie

Ten aanzien van de dagbehandeling gaf de verpleeghuisarts. 23 maal als contactreden aan nader te willen overleggen over patiènten. De inhoud van deze contacten had vooral betrekking op intercurrente problemen (zoals een verergerende wond of een urineweginfectie).

Overleg over de uitslag van screeningsonderzoeken bij dagbehandelingspatiënten was ook een belangrijke contactreden $(n=14)$. Overdracht van informatie over dagbehandelingspatiënten die, na de start in 1996, eveneens in het onderzoeksjaar met de behandeling stopten, was eveneens een belangrijke reden.

Met betrekking tot substitutiepatiënten ging het vooral om schriftelijke rapportage aan de huisarts omtrent de uitslagen van screeningsonderzoeken (46 
maal). Zes keer betrof het verzoeken om nadere informatie. Contact over de daadwerkelijke zorgverlening in het kader van de substiturie vond niet plaats.

De contactredenen voor de verpleeghuisarts in het kader van de consultatiefunctie waren ten slotte allemaal te plaatsen onder de noemer 'reactie op/advisering in het kader van de consultrraag van de huisarts'.

\section{BESCHOUWING}

Uit dit inventariserende onderzoek blijkt dat de verpleeghuisartsen van de Riethorst in 1996 over ruim driekwart van alle nieuwe pariënten contact hebben gehad met de huisartsen. Daarbij is er in feite sprake van éénrichtingsverkeer, waarbij het initiatief in veruit de meeste gevallen bij de verpleeghuisarts ligt en er meestal per nieuwe patiënt een eenmalig contact plaatsvindt. Slechts de consultatiefunctie van het verpleeghuis is voor enkele huisartsen af en toe aanleiding om zelf contact op te nemen.

De meeste contacten blijken telefonisch en/of schriftelijk te verlopen, hetgeen wellicht samenhangt met het feit dat het verkrijgen en verschaffen van overdrachtsinformatie de belangrijkste contactredenen zijn. Mogelijk is hier ook de vigerende aanmeldings- en indiceringsprocedure van nieuwe patiënten van belang. Aanmelding, voor in het verpleeghuis op te nemen patiënten en voor dagbehandelingspatiënten, geschiedt, zoals op vele plaatsen, via de indicatiecommissie aan het maatschappelijk werk van het verpleeghuis, waarbij standaardformulieren gebruikt worden. Op basis van een vervolgonderzoek door het verpleeghuisteam vindt daarna de pre-advisering plaats en vervolgens de definitieve indicatiestelling door de indicatiecommissie, waarbij de verslaglegging ook naar de huisarts wordt gezonden. Het verpleeghuis hanteert daarbij als procedure om, via het secretariaat, bij de huisarts de medische gegevens van aangemelde patiënten op te vragen. Wellicht hebben huisartsen vervolgens nog maar weinig aanleiding om met de verpleeghuisarts contact op te nemen. Daarentegen blijken de verpleeghuisartsen nog wel relatief vaak de behoefte te hebben om extra informatie op te vragen.

Uit het onderzock komen ook aamwijzingen naar voren dat er na opname van een patiënt in het verpleeghuis nog maar weinig contact tussen huisarts en verpleeghuisarts bestaat. Daar waar dit wel gebeurt, ligt het initiatief opnieuw bij de verpleeghuisarts. Zoals uit de resultaten blijkat, gaat het dan overigens zelden over de actuele zorgverlening in het verpleeghuis zelf.

Bij de dagbehandeling blijkent relatief meer contacten te bestaan na de start van de behandeling. Dit is op zich begrijpelijk aangezien ten behoeve van deze nog thuiswonende patiënten, voor wie de huisarts behandelend arts blijft, zorgafstemming extra belangrijk is. Toch gaat het ook in deze contacten niet om de uitwisseling van informatie met betrekking tot het algehele zorgplan, casu quo de eigenlijke zorgverlening op de dagbehandeling.

In de substitutieprojecten is er, behoudens de schriftelijke rapportage omtrent de patièntenscreeningen, eveneens nauwelijks extra contact tussen verpleeghuisarts en huisarts.

Mogelijk hangt ook dit deels samen met vigerende projectafspraken. De indicatiestelling en plaatsingsprocedure van patiënten zijn, conform de landelijke regeling, namelijk strak geregeld. Zo is onder meer toestemming van de huisarts. vereist, omdat deze ook. hier medisch eindverantwoordelijk blijf. Verder hebben de huisartsen in onze regio de gewoonte om in het verzorgingshuis zelf de 
medische gegevens van hun daar verblijvende patiënten te bewaren. De verpleeghuisartsen hebben daar inzage in voor wat betreft de substitutiepatiènten. De huisartsen hebben eveneens inzage in de in het verzorgingshuis aanwezige substitutiestatussen van de verpleeghuisarts en ze mogen daar bovendien zelf in rapporteren, waarbij in de praktijk blijkt dat ze hier vooralsnog wisselend gebruik van maken. In ieder geval is het duidelijk dat de wederzijdse schriftelijke informatie over substitutiepariënten eenvoudig beschikbaar en toegankelijk is.

Ten behoeve van het over en weer inzichtelijk maken van de behandeling, de verpleging en de begeleiding zou het, met het oog op de toenemende gezamenlijke betrokkenheid, aan te bevelen zijn om het gebruik van een gemeenschappelijke rapportage ook te toetsen bij zowel dagbehandelingspatiënten als bij patiënten die langdurig thuis verpleegd moeten worden.

Het hier beschreven onderzoek is slechts inventariserend en niet verklarend van aard.

Aangezien het onderzoek maar is uitgevoerd vanuit één verpleeghuis en het derhalve slechts betrekking heeft op de regio rondom deze zorginstelling, zijn de resultaten mogelijk niet volledig generaliseerbaar. De resultaten kunnen daardoor voor een deel beïnvloed zijn door gangbare procedures die in de regio gelden. Vergelijkbaar en/of ander onderzoek op dit gebied is overigens nog niet verricht. Niet is onderzocht of huisartsen en verpleeghuisartsen vinden dat hun onderlinge contacten er qua aard, frequentic, inhoud en kwaliteit anders zouden moeten uitzien. Ten slotte wordt ook niet ingegaan op de effecten van de contacten tussen huisarts en verpleeghuisarts met betrekking tot de pariëntenzorg zelf.

Aangezien er in Nederland vooral in beschouwende zin is gepubliceerd over de samenwerking tussen huisarts en verpleeghuisarts en specifiek wetenschappelijk onderzoek op dit gebied ontbreekt, is nader onderzoek, dat breder en meer gedetailleerd is opgezet, noodzakelijk om het huidige niveau van samenwerking nauwkeuriger te beschrijven. Ook dienen de omstandigheden te worden bepaald, waaronder deze samenwerking meer geïntegreerd kan zijn. ${ }^{4}$ De relevantie van dergelijk onderzoek wordt onderschreven in het recent verschenen NIVELrapport over verpleeghuiszorgonderzoeks.

In de eerstelijn zal men in de toekomst in toenemende mate met chronisch zieke mensen en ook ouderen te maken krijgen, waarbij sprake is van een groeiende vraag naar samengestelde zorg, die bij voorkeur semimuraal, in de thuissituatie of in het verzorgingshuis geboden zal moeten worden. De complexiteit van de zorgvraag vereist daarbij een goede continuïteit van zorg, die tot stand kan komen op basis van goed met elkaar samenwerkende hulpverleners, waaronder de huisarts en de verpleeghuisarts. 


\section{LITERATUUR}

1. Schols JMGA, Wierik MJM te. Verplecghuisoorg buiten de murent dagbehandeling, consultatic en substiturieprojecten. Ned Tijdschr Generskd 1993:137:2717-22.

2. Wierik MJM te, Dijk P van, Stomph ECA, Frederiks CMA, Hollands L Substitutieprojecten verplecghuiszorg een onderwoek naar zorgzwarte en kwaliteitaspecten van zorg in verplecg-en vernorginghuizen. Dwingeloo: KAVANAH, 1994.

3. Schols JMGA. Theunisten NJS, Bont V, Sinnema ME. Verpleeghuiszorg in beweging: een inventariserend overzicht van vijf substiturieprojecten verplecghuisaorg. Tijdschr Gerontol Geriarr 1995:26:10-5.

4. Schols JMGA, Diederilo JPM, Koopmans RTCM. Samenwerking tussen verpleeghuisarts en huisarts: de pariërir moet er beter vas worden. Tijdschr Verplecghuisgeneeskd 1997:21:10-4 (chemant, nov, ).

5. Veer AJE de, Kerkstra A. Verpleeghuiszorgonderzocks stand van zaken en relevante onderzoeksvelden. Rapport. Utreche NIVEL, 1997. 


\title{
VARIATIE IN SAMENWERKINGS- INTENSITEIT TUSSEN VERPLEEGHUISARTS EN HUISARTS IN NEDERLAND
}

J.M.G.A. Schols, A.J.E. de Veer, A. Kerkstra, J.P.M. Diederiks,

\author{
R.T.C.M. Koopmans, F. Sturmans, H.F.J.M. Crebolder
}




\section{SAMENVATTING}

Een inventariserend onderzoek werd uitgevoerd naar de intensiteit van de samenwerking tussen verpleeghuisartsen en huisartsen (1998). Daartoe werd aan de hoofden medische dienst van alle gecombineerde verpleeghuizen in Nederland $(\mathrm{n}=220)$ cen korte vragenlijst toegezonden. De respons op deze enquête was hoog (98\%). Uit de resultaten blijkt dat er in ons land inmiddels sprake is van een duidelijke transmurale profilering van de verpleeghuizen. De meeste verpleeghuizen bieden dagbehandeling en hebben projecten waarin verpleeghuiszorg thuis of in een verzorgingshuis wordt geboden. De frequentie van contacten tussen huisartsen en verpleeghuisartsen in het kader van de verpleeghuisdagbehandeling, de consultatiefunctie en de substitutieprojecten is in het algemeen nog laag. De samenwerkingsintensiteit in substitutieprojecten wordt positief beïnvloed door het aanwezig zijn van samenwerkingsafspraken, door een gezamenlijke betrokkenheid bij de zorg en door een financiële prikkel voor de huisartsen. De samenwerkingsintensiteit blijkt verder groter te zijn in minder verstedelijkte gebieden en wanneer deze gestalte krijgt vanuit verpleeghuizen waarin de verpleeghuisartsen een lagere klinische werklast hebben. Nader onderzoek naar de concrete en gewenste samenwerking tussen verpleeghuisarts en huisarts is wenselijk.

\section{SUMMARY}

Variation in coopenation-intensity between nursing home physician and general practitioner in the Netherlands

92 An inventory was made on the intensity of contacts between general practitioners (GPs) and nursing home physicians (1998). A questionnaire was sent to the chiefs of the medical departments of all combined nursing homes (for somatic and psychogeriatric patients) in the Netherlands $(n=220)$. The response was high $(98 \%)$. The contact-intensity between nursing home physicians and GPs with regard to nursing home day-care and consultative activities is still low. The contact-interisity in projects for substitute care is positively influenced by agreements with regard to the cooperation, by actually working together for patients and by financial stimuli for the GPs.

Furthermore the cooperation is more intense in rural areas and when nursing home physicians are involved who have a lower clinical workload. More research is necessary with regard to the actual and desirable cooperation between nursing home physicians and GPs. 


\section{INLEIDING}

De gezondheidszorg voor ouderen en voor mensen met een chronische ziekte is volop in beweging. Demografische ontwikkelingen, lange wachtlijsten voor de chronische zorg en budgettaire beperkingen zijn aanleiding tot heroverweging van de organisatie van de zorg. Daarbij staan fenomenen als individualisering, deinstitutionalisering, normalisatie en integratie centraal. Ontschotting van het zorgbestel, substitutie van zorg en transmuralisering moeten tot een optimale en doelmatige continuïteit van zorg leiden, waarmee vervolgens individuele zorg op maat gerealiseerd kan worden. ${ }^{14}$ Deze ontwikkeling van de zorg geeft een enorme impuls aan de interactic russen zorgvragers, zorgaanbieders, zorgverzekeraars en overheid. Daarbij wordt transmurale samenwerking tussen individuele en institutionele zorgaanbieders steeds belangrijker."

In dit artikel staan de huisarts en de verplecghuisarts, rwee hulpverleners die actief zijn in de zorg voor ouderen en chronisch zieken, centraal. In het algemeen is de kennis over de samenwerking tussen huisarts en verplecghuisarts onduidelijk en versnipperd. Daar waar er over dit onderwerp is gepubliceerd, gebeurde dit vooral in beschouwende zin." Specifick wetenschappelijk onderzoek op dit gebied is nog nauwelijks voor handen.

Sinds eind jaren tachtig is er sprake van een toenemende transmurale profilering van de verpleeghuizen." In de eerste plaats maken vele patiènten ambulant gebruik van de verpleeghuisdagbehandeling. Ten tweede heeft elk verpleeghuis een consultatiefunctie. Deze stelt de eerstelijn in de gelegenheid om consultatief een beroep te doen op de zorgexpertise van het verpleeghuis. Ten derde zijn er inmiddels tal van substitutieprojecten verpleeghuiszorg voor verpleeghuisgeïndiceerde patiēnten, die, primair wegens plaatsgebrek, niet in een verpleeghuis opgenomen kunnen worden. Zij kunnen daarmee extra ondersteuning vanuit het verpleeghuis krijgen, die complementair is aan de reeds aanwezige eerstelijnszorg." Vooral in verzorgingshuizen is deze verpleeghuis-substitutiezorg gemeengoed geworden.

Deze ontwikkelingen, waardoor verpleeghuisartsen en huisartsen elkaar semi- en extramuraal frequenter in het werk ontmoeten, hebben her en der tor samenwerkingsproblemen geleid. Daarbij gaat het vooral om de vraag wie nu de medische eindverantwoordelijkheid blijft dragen."121?

Het hier gepresenteerde onderzoek betreft een inventariserend kwantitatief onderzoek naar de landelijke variatie in samenwerkingsintensiteit tussen huisartsen. en verpleeghuisartsen en enkele mogelijke determinanten daarvan Het werd uitgevoerd in het kader van een plan voor een groter onderzoeksproject, onder zowel verpleeghuisartsen als huisartsen, dat beoogt de actuele samenwerking nader in kaart te brengen en tevens condities te formuleren waaronder die samenwerking verbeterd kan worden.

In dit inventariserend onderzoek worden de volgende vragen beantwoord:

1. Hoe intensief wordt er, gemeten aan de hand van de contactfrequentie, samengewerkt door verpleeghuisartsen en huisartsen?

2. Hangt de intensiteit van de samenwerking samen met de wijze waarop de samenwerking georganiseerd is?

3. Hangt de intensiteit van de samenwerking samen met achtergrondkenmerken van verpleeghuizen? 


\section{METHODE}

\section{Onderzoeksgroep}

Aan de hoofden Medische Dienst van alle gecombineerde verpleeghuizen (met zowel somatische als psychogeriatrische afdelingen) in Nederland ( $\mathrm{n}=220$ ) werd eind 1998 een korte vragenlijst gestuurd. Er werd gekozen voor gecombineerde verpleeghuizen om in het onderzoek op voorhand verschillen uit te sluiten gerelateerd aan de categorie van het verpleeghuis (alleen psychogeriatrisch, alleen somatisch, of beide). Van de deelnemende verpleeghuizen waren de volgende basiskenmerken bekend: de plaats van vestiging, de urbanisatiegraad (conform de CBS-classificatie van de omgevingsadressendichtheid), het aantal bedden in de kliniek en de dagbehandelingscapaciteit.

\section{Meetinstrument}

De vragenlijst met 13 vragen bestond uit twee delen. Het eerste deel bevatte twee vragen over het aantal werkzame verpleeghuisartsen en over het aantal huisartsen; twee vragen over de frequentie van de contacten met huisartsen in het kader van de dagbehandeling en de consultatiefunctie met antwoordmogelijkheden variërend van wekelijks (score 5) tot zelden of nooit (score 1); één vraag over eventuele fusie tussen verpleeghuis en verzorgingshuis; en twee vragen over eventueel aanwezige substiturieprojecten in verzorgingshuizen, respectievelijk de thuissituatie.

Het tweede deel hoefde alleen ingevuld te worden indien er inderdaad substiturieprojecten waren. Dit deel betrof zes aan deze projecten gerelateerde vragen over respectievelijk: het wel of niet aanwezig zijn van formele afspraken met huisartsen; her wel of niet concreet samen bij de zorg betrokken zijn van huisarts en verpleeghuisartsi de frequentic van persoonlijke (inclusief telefonische), respectievelijk schriftelijke contacten russen huisarts en verpleeghuisarts met antwoordmogelijkheden variërend van wekelijks (score 5) tot zelden of nooit (score 1); her wel of niet gebruikmaken van één gemeenschappelijk zorgdossier; en her wel of nier verstrekken van een financiële vergoeding aan de huisartsen.

\section{RESULTATEN}

Van de verstuurde enquêtes $(\mathrm{n}=220$ ) werden er 189 geretourneerd $(85,9 \%)$. Teiefonisch werden nog 27 vragenlijsten afgenomen (12,3\%). De totale respons bedroeg daarmee $216(98,2 \%)$. Vier vragenlijsten bleken onbruikbaar voor verwerking. De bruikbare respons was derhalve $212(96,4 \%)$.

Het gemiddeld antal in een verpleeghuis werkzame verpleeghuisartsen bedroeg 4 (sd 1,9) op gemiddeld 3, full-time formatie-eenheden (sd 1,5).

In de werkgebieden van de verpleeghuizen werkten gemiddeld 50 hurisartsen per verpleeghuis (sd 59,2; spreiding 4-500). Van de respondenten gaven er 132 aan dat hun verpleeghuis gefuseerd was met een verzorgingshuis $(62,3 \%)$.

\section{Variatie in de intensiteit van samenwerking}

Tabel 1 toont achtereenvolgens de aangegeven frequentie waarin verpleeghuisartsen door huisartsen geconsulteerd worden, de frequentie waarin er sprake is van contact tussen verpleeghuisarts en huisarts met betrekking tot dagbehandelingspatiënten en de frequentie van. het contact dat bestaat in relatie tot de zorgverlening aan in substitutieprojecten participerende patiënten. 
TABEL 1

Intensiteit van de contacten tussen verpleeghuisartsen en huisartsen in het kader van de consultatiefunctie, de dagbehandeling en in relatie tot de substitutieprojecten.

\begin{tabular}{|c|c|c|c|c|}
\hline & $\begin{array}{l}\text { consultatie } \\
\text { door } \\
\text { huisartsen } \\
(n-212)\end{array}$ & $\begin{array}{l}\text { afstemmings. } \\
\text { contact bij } \\
\text { doghehondeling } \\
(n-212)\end{array}$ & $\begin{array}{l}\text { persoontyik enjof } \\
\text { telefonisch overieg } \\
\text { (substitutieproj.) } \\
(n-205)\end{array}$ & $\begin{array}{l}\text { schriftelijk } \\
\text { contact } \\
\text { (substitutieproj.) } \\
\text { (n-205) }\end{array}$ \\
\hline Wekelijks & $16,5 \%$ & 17,04 & $18,5 \%$ & 7,35 \\
\hline Maandelijks & 17.08 & 16,04 & $23,9 \%$ & $13,6 \%$ \\
\hline Enkele malen per half jaar & $22,6 \%$ & $18,9 \%$ & $28,3 \%$ & $19,5 \%$ \\
\hline Enkele malen per jaar & $25,9 \%$ & $18,4 \%$ & $16.6 \%$ & 17,05 \\
\hline Zelden of nooit & $17.5 \%$ & 29,74 & 12,24 & $40,5 \%$ \\
\hline Geen antwoord & $0,5 \%$ & . & $0.5 \%$ & 2,18 \\
\hline Totaal & $100,0 \%$ & $100,0 \%$ & $100,0 \%$ & $100,0 \%$ \\
\hline
\end{tabular}

Kolompercentages van de respons van hoofden medische dienst van gecombineerde verpleeghuiren

Eenderde $(33,5 \%)$ van de respondenten geeft aan dat de verpleeghuisartsen van hun verplecghuis wekelijks of maandelijks door een van de huisartsen uit het verzorgingsgebied geconsulteerd wordt voor een patièntenprobleem. In $43.4 \%$ van de verpleeghuizen gebeurt dit zelden tor hoogstens enkele malen per jaar.

Ten aanzien van de contacten in her kader van de dagbehandeling is eveneens bij eenderde $(33,0 \%)$ van de verpleeghuizen sprake van een wekelijks of maandelijks afstemmingscontact tussen verpleeghuisartsen en een of meer huisartsen, over de zorgverlening aan pariënten. In $48,1 \%$ van de gevallen geschiedt dit zelden tot enkele malen per jaar.

Van de aangeschreven verpleeghuizen waren er 205 betrokken bij substiturieprojecten in verzorgingshuizen $(96,7 \%)$ en 104 ook bij substitutieprojecten ten behoeve van verpleeghuisgeïndiceerden die nog thuis wonen $(49,1 \%)$.

Het tweede deel van de enquête werd derhalve ingevuld door 205 respondenten. $\mathrm{Bij} 42,4 \%$ hiervan is sprake van wekelijks tot maandelijks persoonlijk en/of telefonisch overleg tussen bij de substitutieprojecten betrokken verpleeghuisartsen en huisartsen over de concrete zorgverlening aan participerende patiënten. In ruim een kwart $(28,8 \%)$ van de verpleeghuizen gebeurt dit zelden, tot hoogstens enkele malen per jaar.

Wekelijks tot maandelijks, schriftelijk contact over substitutiepatiënten, tussen bij de projecten betrokken verpleeghuisartsen en huisartsen, werd door eenvijfde van de respondenten gerapporteerd $(20,9 \%)$, terwijl dat in ruim de helft van de gevallen zelden, tot hoogstens enkele malen per jaar $(57.5 \%)$ zou geschieden.

\section{Intensiteit van samenwerking in substitutiezorg en de wijze van organisatie}

Uit de totaal-kolom van tabel. 2 blijkt dat ruim de helf $(53,9 \%)$ van de verpleeghuizen, in het kader van de substitutieprojecten, geformaliseerde afspraken heeft met huisartsen. Binnen de substiturieprojecten zijn de huisarts en verpleeghuisarts meestal $(65,8 \%)$ samen betrokken bij de zorgverlening (dat wil zeggen bij het opstellen en uirvoeren van het zorgplan). Minder frequent wordt aangegeven dat gebruik gemaakt wordt van een gezamenlijke zorgrapportage of zorgdossier ten behoeve van de aan de projecten deelnemende patiënten $(23.3 \%)$ en dat huisartsen voor hun participarie een financiële vergoeding krijgen $(14,0 \%)$.

Nagegaan is wat de relatie is van deze organisatorische aspecten met de gerappor- 


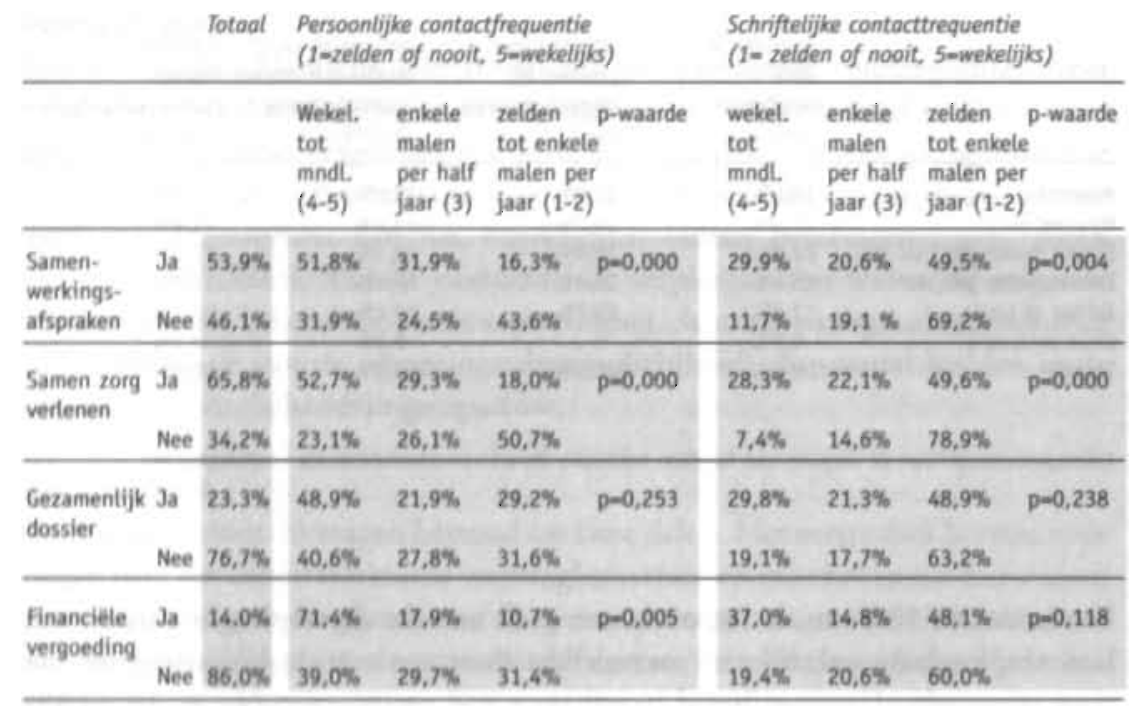

TABEL 2

De samenhang tussen de contactfrequentie met huisartsen in substitutieprojecten in enkele organisatorische kenmerken van de samenwerking $(n=205)$.

* Chi-kwadraattoets (indien p>0,05 dan niet significant)

Totaalkolom = kolompercentages; alle overige percentages zijn rij-percentages.

teerde contactfrequentie. Her blijkt dat samenwerkingsafspraken en gezamenlijke zorg statistisch significant samenhangen met een frequenter contact tussen verpleeghuisarts en huisarts, zowel persoonlijk als schriftelijk (tabel 2); voor wat betreft her item financiële vergoeding voor de huisartsen geldt deze significante samenhang met name het frequentere persoonlijke contact. Het gebruik van een gezamenlijk zorgdossier is niet significant gerelateerd aan de contactfrequentie.

\section{Intensiteit van samenwerking en kenmerken verpleeghuis}

In de analyse werden vervolgens de huizen geselecteerd waarvan het meest te verwachten is dat er intensieve samenwerking tussen verpleeghtuisartsen en huisartsen is. Dait zijn verpleeghuizen die dagbehandeling en substiturieprojecten hebben (-daarnaast mag men ervan uitgaan dat alle verpleeghuizen tegenwoordig een consultatiefunctie hebben). İmmers bij dagbehandelingspatiënten en patiënten die substituerende verpleeghuiszorg ontvangen, blijft de huisarts eindverantwoordelifk. voor de medische zorg. Daarna werden uit deze groep twee extreme groepen verpleeghuizen geselecteerd: verpleeghuizen die intensief samenwerken met huisartsen en verpleeghuizen die nauwelijks samenwerken. De criteria voor intensieve samenwerking waren dat er minstens maandelijks contact tussen de verpleeghuisartsen en een of meer huisartsen uit het verzorgingsgebied moest zijn in het kader van de dagbehandeling, én de consultatiefunctie, terwijl dit voor niet intensief samenwerkende huizen hoogstens enkele malen per jaar her geval mocht zijn. Vervolgens werd met Student's t-toetsen (bij variabelen gemeten op inter$\mathrm{val} / \mathrm{ratio}$ niveau) en Chi-kwadraattoetsen (bij variabelen gemeten op nominaal niveau) nagegaan of de verpleeghuizen die intensief met huisartsen samenwerken $(\mathrm{n}=40)$ verschilden van verpleeghuizen die minder intensief samenwerkten $(\mathrm{n}=37)$.

Tabel 3 toont enkele achtergrondkenmerken van de intensief en minder intensief 


\begin{tabular}{|c|c|c|c|}
\hline & $\begin{array}{l}\text { verplenghuisen met in. } \\
\text { temsine samenueribing } \\
\text { met huisersen (n-40) }\end{array}$ & $\begin{array}{l}\text { vepleeghuiten met minder } \\
\text { intensieve samenwerking met } \\
\text { huisartsen (n-37) }\end{array}$ & \\
\hline $\begin{array}{l}\text { Verpleeghuizen in sterk } \\
\text { stedeijike gebieden }\end{array}$ & $27.5 \%$ & $54,1 \%$ & $p=0,018$ \\
\hline Gemiddeld aantal bedden & 191,6 & 194,0 & ns: \\
\hline $\begin{array}{l}\text { Gemiddeld aantal dagbehan- } \\
\text { defingsplaatsen }\end{array}$ & 18,1 & 18,1 & $\mathrm{~ms}$ \\
\hline $\begin{array}{l}\text { Gemiddeld aantal verpleeg. } \\
\text { huisartsen per verpleeghuis }\end{array}$ & 4,5 & 3,8 & ns. \\
\hline $\begin{array}{l}\text { Gemiddeld aantal bedden per } \\
\text { verpleeghuisarts }\end{array}$ & 67,6 & 60,4 & $p=0,011$ \\
\hline $\begin{array}{l}\text { Gemiddeld aantal dagbehandelings- } \\
\text { plaatsen per verpleeghuisarts }\end{array}$ & 4,4 & 5,6 & ns \\
\hline $\begin{array}{l}\text { Gemiddeld aantal huisartsen } \\
\text { in verzorgingsgebied verpleeghuis }\end{array}$ & 46,3 & 53,0 & ms \\
\hline $\begin{array}{l}\text { Wel substitutieprojecten in } \\
\text { thuissituatie }\end{array}$ & $62,5 \%$ & $45.9 \%$ & ns \\
\hline $\begin{array}{l}\text { Wel gefuseend met } \\
\text { verzorgingshuis(-zen) }\end{array}$ & $70,0 \%$ & $56,8 \%$ & ss \\
\hline
\end{tabular}

Intensieve samenwerking betekent dat et vanuit het verpleeghuis minstens maandelijks contact tussen de verpleeghuisartsen en een of meer huisartsen in het verzorgingsgebied is in het kader van de dagbehandeling èn de consultatiefunctie, terwijl dit bij minder intensieve samenwerking hoogstens enkele malen per jaar het geval is.

samenwerkende verpleeghuizen. Vergelijking van beide groepen verpleeghuizen met betrekking tot verschil in achtergrondkenmerken leverde het volgende beeld op. Intensieve samenwerking komt vaker voor in de minder verstedelijkte gebieden. In de groep verpleeghuizen met een intensieve samenwerking was het gemiddeld aantal bedden per verpleeghuisarts significant lager dan in de groep met een minder intensieve samenwerking. Voor deze groep verpleeghuizen leek, aan de ene kant, ook het gemiddeld aantal dagbehandelingsplaatsen per verpleeghuisarts en het gemiddeld aantal huisartsen in het verzorgingsgebied lager te zijn, en de betrokkenheid bij substitutieprojecten in de thuissituatie en bij fusies met verzorgingshuizen groter. De verschillen tussen beide groepen ten aanzien van deze kenmerken waren echter niet significant.

\section{BESCHOUWING}

In dit inventariserende onderzoek is getracht een beeld te schetsen van de variatie in intensiteit van de samenwerking tussen verpleeghuisartsen en huisartsen. Ondanks het feir dat een tiende deel van de respons telefonisch werd verkregen, lijkt de totale respons $(98 \%)$ toch een duidelijke graadmeter voor de actualiteit van deze samenwerking.

Wat de actuele samenwerkingsintensiteit van verplecghuisartsen en huisartsen 
betreft, wordt vanuit eenderde van de gecombineerde verpleeghuizen aangegeven dat er regelmatig contact met de huisartsen bestaat in het kader van de consultatiefunctie en de dagbehandeling; in bijna de helft van de gevallen is dit nog slechts in geringe mate het geval. Deze bevindingen sluiten aan bij eerder onder-

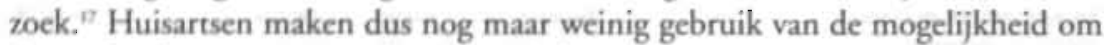
de verpleeghuisarts te consulteren ten behoeve van patiënten met een chronische ziekte en een complexe hulpvraag. Dit terwijl er toch steeds meer van dergelijke patiënten in de eerstelijn aanwezig zijn. ${ }^{.45}$ De lage contactfrequentie in het kader van dagbehandelingspatiënten is ook opvallend, omdat deze patiënten slechts ambulant van de verpleeghuisfuncties gebruik maken en onder de medische eindverantwoordelijkheid van de huisarts blijven vallen. Aangezien de zorg op de dagbehandeling complementair is aan de zorg die de patiënten in de eerstelijn zelf ontvangen, zou hier een frequenter afstemmingscontact tussen verpleeghuisarts en huisarts verwacht mogen worden.

In substitutieprojecten van verpleeghuizen lijkt de intensiteit van samenwerking wat hoger te liggen. In de helft van de gevallen blijkt in ieder geval sprake van samenwerkingsafspraken met huisartsen en frequent wordt aangegeven dat huisartsen en verpleeghuisartsen op patiëntniveau samen betrokken zijn bij de zorgplandefinitie en uitvoering. Dit laatste komt overigens nog niet echt tot uiting in het gebruik van een gezamenlijke zorgrapportage. Slechts in één op de zeven gevallen wordt gerapporteerd dat huisartsen ook een financiële vergoeding krijgen voor hun participatie aan de projectactiviteiten van de verpleeghuizen, omdat in de aparte projectfinanciering ook een vergoeding voor de huisarts is opgenomen. Dit hangt samen met het feit dat er vaak extra acties (consultaties/ visites) van de huisarts gevraagd worden, in het verlengde van de advisering die door de verpieeghuisarts heeft plaarsgevonden, ten behoeve van aan het project deelnemende patiënten.

Uit de resultaten blijkt dat de contactfrequentie tussen huisartsen en verpleeghuisartsen significant hoger is in die gevallen waarbij in de substitutieprojecten respectievelijk sprake is van formele samenwerkingsafspraken met de huisartsen, van het samen zorgverlenen door de huisarts en de verpleeghuisarts en van een financiële vergoeding voor de huisartsen. Hiermee zou in relatie tor nieuwe samenwerkingsinitiatieven dan ook rekening gehouden moeten worden.

De verpleeghuizen uit de groep van waaruit een intensieve samenwerking met huisartsen bestaat, blijken vaker gelegen te zijn in minder verstedelijkte gebieden. Uit dit onderzoek blijkt niet dat dit ligt aan verschillen in de capaciteit van de betrokken verpleeghuizen of in het aantal huisartsen in het adherentiegebied van de verpleeghuizen. Een voor de hand liggende, maar niet onderzochte verklaring zou kunnen zijn dat verpleeghuisartsen en huisartsen in minder verstedelijkte gebieden sterker op elkaar aangewezen zijn omdat ze er vaak contact hebben met slechts één verpleeghuis. In (grote) steden, waar vaak meerdere verpleeghuizen zijn, is hiervan minder sprake.

De verpleeghuisartsen uit de verpleeghuizen die intensief samenwerken met huisartsen, blijken significant minder klinische bedden onder hun hoede te hebben en ten aanzien van de dagbehandeling zeker niet meer belast te zijn. Dit kan wellicht een aanwijzing zijn voor het feit dat zij een meer specifieke taak hebben in relatie tot de projectactiviteiten.

Heden ten dage blijken bijna alle gecombineerde verpleeghuizen betrokken te 
zijn bij substitutieprojecten in verzorgingshuizen. Tweederde van hen is bovendien reeds gefuseerd met een verzorgingshuis en ook de helft is reeds betrokken bij projecten ten behoeve van nog thuis wonende patiēnten. In het licht van de dynamiek in de ouderenzorg geven de getallen duidelijk aan hoe sterk de interactic tussen verplecghuis en verzorgingshuis is geworden. Ze bevestigen bovendien de zich voltrekkende transmuraliteit vanuit de verpleeghuizen. Deze ontwikkelingen moeten uiteindelijk wel gevolgen hebben voor de samenwerking tussen huisarts en verpleeghuisarts. Met name de medische zorg in verzorgingshuizen, waar een toenemend aantal bewoners een groeiende zorgbehoefte vertoont, staat op dit moment in de schijnwerpers. Voor een deel van deze bewoners wordt en zal de zorg steeds meer georganiseerd worden analoog aan het zorgmodel van het verpleeghuis. Uiteraard zal dit ook consequenties voor de medische zorgverlening hebben. ${ }^{\text {wis }}$

Het hier uitgevoerde onderzoek is inventariserend en kwantitatief en niet verklarend en kwalitatief van aard. Beperkingen kunnen, ondanks het feit dat de vragenlijsten door de respondenten volledig waren ingevuld, gelegen zijn in de nauwkeurigheid van de gehanteerde vragen en wellicht ook in de betrouwbaarheid van het invullen ervan. Bovendien werd een klein deel van de vragenlijsten telefonisch afgenomen. Het is dan ook wenselijk om zowel meer pariëntgebonden onderzoek te verrichten, als onderzoek onder huisartsen en verpleeghuisartsen zelf. Daarmee kan inzicht verkregen worden in de concrete en wenselijke intensiteit van de samenwerking, evenals in de bevorderende en belemmerende factoren om deze samenwerking op een kwalitatief hoger niveau te brengen. 


\section{LITERATUUR}

1. Dokter H. Ontwikkelingen in her aanbod. In: Dolkter H. Lieshout P van, Schade B (red). Zorg aan huik, een sand van aken. Utreche: De Tijdatroom, 1996: $13-30$.

2. Fontrin $\mathrm{E}$ Transmurale zorg een inleiding In: Cerbolder HFJM e. (red). Handbock Thuisuorg (HAT). Utreche De Tijatroom, 1997; B 9.1-1/13.

3. Commiasie Modernikering Curatieve zorg (cie. Biesheuvel). Nota Gedeelde norg betere zorg. Zoctermeer, Hageman BV: 1994.

4. Commisaic Modernisering Ouderennorg (cie, Welschen). Nota Ouderenzorg mer tockomst. Zoetermeer, Hageman/Ministerie van WVC: 1994.

5. Bos GAM van den. Ondernoek naar de gevolgen van chronische aandoeningen in de geasondheidsarg. Kwalieit van zorge Tijdsche Soc Gezondheidex 1991; 69: 237-41.

6. Heuvel WJA van de. De uitdaging van een verouderende samenleving en de kansen voor het beleid. Het Zirkenhuis 1994; 24 (11): 460-1.

7. Ammann PEMTh, e.a. Samenwerken gat niet vanzedf. Wat men vindt en war men wenst. Medisch Contacr 1996: 51: 637-8.

8. Kate R. Oplosing cranumurale mysterie stapie naderbij. Het Ziekenhuis $1996 ; 26$ (1): $34-5$.

9. Schols JMGA, Diederika JPM, Koopmans RTCM. Samenwerking tussen huisarts en verplecphuisarts twee actoren in een veranderende ouderenzorg. In: Crsbolder HFJM e.a. (red). Handbock Thuisaorg (HAT). Utreche De Tijdstroom, 1997: B. 8.2.-1/20.

10. Haan M de, Ribbe MW. Huisartsgenesklunde en verplecghuisgeneskunde; een vergelijking. Ned Tijdechr Geneeskd 1993, 137: 2696-701.

11. Schols JMGA, Wierik MJM te. Verplecghuiszorg buiten de muren: dagbehandeling, consultatie en substitutieprojecten. Ned Tijdschr Geneeskd 1993; 137: 2717-22.

12. PAOG-cursus: Samengestelde zorg voor ouderen: de huisarts en verplecghuisarts voordeurdelers? Nijmegen: PAOG. 1997.

13. Lafficte CRJ, Verdenius W. Substitutie zonder betrokkenheid tot mislukken gedoemd. Medisch Contact 1989: 44: 114-8.

14. Linschoten CP van eas. De gevolgen voor de huisars van de substiturie van verplecghuiszorg. Huisart Wet 1996; 39; 162-4.

15. Wierik MJM, te. Dijk P van. Stomph ECA. Frederils CMA. Hollands L. Substitutieprojecten verplecghuiszorg. Een ondernock nar zorgzwarte en kwaliteitsaspecten van zorg in verpleç- en verzorgingshuizen. Dwingeloo: KAVANAH, 1994.

16. Beer MFjM de, Fahrenfort M. Verplecghuiszorg buiten de muren. De rol van de huisarts. Medisch Contact 1993; 48: 597-9.

17. Schols JMGA. Koopmans RTCM, Diederils JPM, Sturmans F, Crebolder HFJM. Contacten tussen verpleqghuisarts en huisarts; frequentic, aard en inhoud. TSG/Tijdschr Gezondheidsw 1998; 76: 318-22.

18. Ende PC van der. Medische zorg in verzorginghuizen. Inventarisarie van mogelijkheden met her oog op organisatie en financiering vanaf het jar 2001. Groningen: Gerontagogisch Centrum (GCG), 1997.

19. NVVA en L.HV. Nota: Arss en ouderen: uitdagende zorg. Een stap vooruit in de samenwerking russen huisars en verpleeghuisarts. Utreche: LHV/NVVA, 1998. 


\section{NADERE BESCHOUWING VAN DE SAMENWERKING TUSSEN VERPLEEGHUISARTS EN HUISARTS; VARIATIE IN CONTINUÏTEIT VAN MEDISCHE ZORG GERELATEERD AAN DIVERSE SAMENWERKINGS- VARIABELEN}

J.M.G.A. Schols, A.J.E. de Veer, A. Kerkstra, J.P.M. Diederiks,

R.T.C.M. Koopmans, F. Sturmans, H.F.J.M. Crebolder 
Deze uitvoerige paragraaf wordt nog bewerkt tot een of meer artikelen.

De samenvatting is opgenomen in de algemene samenvatting van het proefschrift.

Analysis of the cooperation between nursing home physician (NHP) and general practitioner (GP); variation in continuity of medical care related to various aspects of cooperation.

This paragraph will be transformed into one or more publications.

The summary of the paragraph is included in the general summary of this dissertation. 


\section{INLEIDING}

Naar verwachting krijgt de gezondheidszorg in de nabije toekomst te maken met een sterke stijging van het aantal, veelal oudere, patiënten met meervoudig complexe hulpvragen. Deze zorgvragers zullen naast medische behandelingen ook andere zorg nodig hebben, die niet of bij voorkeur niet in een instelling wordt gegeven.' Afstemming tussen de behandelingen en zorgpakketten van verschillende zorgaanbieders is dan nodig om een continue en integrale zorg te kunnen bieden. Mede daardoor is in de hedendaagse gezondheidszorg het fenomeen van de "transmuraliteit" actueel geworden. Andere achtergronden hiervoor zijn het, mede van overheidswege, voorgestane streven naar de-institutionalisering en zorgsubstitutie.' Transmurale samenwerking kan een antwoord bieden op de enigszins verkokerde structuur van de gezondheidszorg, waarbij de actuele afstand tussen extramurale en intramurale zorg vooral te maken heeft met verschillen in wijzen van werken.' Toenemend komt men tot het besef dat hierdoor vaak communicatic- en samenwerkingsproblemen ontstaan en dat deze situatic leidt tot discontinuiteit in de zorg, tot ondoelmatigheid en tot een onvoldoende op de zorgvrager afgestemde zorg. Hierdoor ontstaat geleidelijk aan een klimaat om te werken aan diverse samenwerkingsrelaties in de medische en verpleegkundige as.'

Hier staat de samenwerking tussen huisarts en verpleeghuisarts centraal.

De genoemde veranderingen in de zorg maken deze samenwerking tot een actueel, relevant en interessant onderwerp., De voorgestane de-institutionalisering en accentuering van de thuiszorg leiden er immers toe dat ook intramurale instellingen in toenemende mate (complementaire) thuiszorgarrangementen gaan aanbieden. Ook het verpleeghuis heeft zich hier, sinds 1989 , met zijn substitutieactiviteiten reeds in gemanifesteerd.' Juist door deze extramuralisering van de verpleeghuiszorg verandert de relatie tussen verpleeghuisarts en huisarts, omdat ze samen betrokken raken bij de medische zorgverlening aan zorgbehoevende ouderen die langer thuisblijven. ${ }^{36}$

\section{Literatuurverkenning}

Er is nauwelijks Nederlandse literatuur beschikbaar over de samenwerking tussen huisarts en verpleeghuisarts. Her en der is wel gewezen op de mogelijkheden en

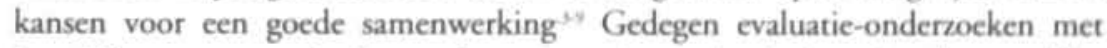
betrekking tot consultatic-ervaringen vanuit verpleeghuizen in de cerstelijn, alsmede van samenwerkingsactiviteiten tussen huisartsen en verplecghuisartsen in het kader van substitutieprojecten ontbreken.' Ook de internationale literatuur biedt hier geen additionele bijdrage. Een literatuuronderzoek in Medline leverde in dit verband geen bruikbare gegevens op. De redenen daarvoor zijn waarschijnlijk dat her Nederlandse verpleeghuis geen volledig vergelijkbare equivalent heeft in het buitenland én ook dat de specifiek geregistreerde functie van de verpleeghuisarts hier, in feite uniek is in de wereld.

Verpleeginstituten in Engeland en in Amerika (nursing homes en long term care facilities) bijvoorbeeld kennen een kwalitatief uiteenlopende medische zorg, die in het algemeen geleverd wordt door huisartsen met een zeer wisselende belangstelling voor de medische zorg in deze instellingen. Groot is daar dan ook de roep om een betere medische zorg in dergelijke instituten. ${ }^{1.14}$ Ook in de Duitse Pflegeheimen en in de Belgische tehuizen voor ouderen wordt de medische zorg op afroep door huisartsen geleverd. 
Ten aanzien van de samenwerking en communicatie tussen huisarts en medisch specialist is duidelijk meer onderzocht en geschreven. Dit heeft onder meer te maken met de aan huisartsen toegeschreven "poortwachtersfunctie". $1 .-17$ Doordat huisartsen via hun verwijsbeleid in sterke mate de samenstelling van het patiëntenbestand van specialisten bepalen, hebben zij uiteraard een wezenlijke invloed op de zorgverlening door de specialisten." Gestructureerde samenwerking tussen huisarts en specialist op het gebied van verwijzen, het fenomeen "korte kaart" (= consultkaart) en het houden van gezamenlijke patiëntenbesprekingen, blijken oplossingen te bieden voor onnodige verwijzingen en ook bij te dragen tot een kwalitatief meer gestroomlijnde medische zorg. ${ }^{1930}$

In dit verband is voorts gerapporteerd over de rol van de verwijsbrief, de functie van automatisering en de invloed van telefonische consultatic. 1.36

Daarnaast zijn inmiddels ook gegevens beschikbaar over het fenomeen gezamenlijke consultatie in de eerstelijn, waarbij de consultverlener (specialist) en de consultvrager (huisarts) samen de patiënt zien en waarbij de consultvrager tot aan de eventuele, daadwerkelijke verwijzing de verantwoordelijkheid blijft behouden. Doelen van deze gezamelijke consultatie betreffen deskundigheidsbevordering, preventie van onnodige verrichtingen en verwijzingen, gerichter verwijzen en het verbeteren van de communicarie tussen huisarts en specialist. ${ }^{.3}$ Vierhout beschrijft op duidelijke en onderbouwde wijze de baten van zo'n gezamenlijk consult van huisarts en specialist; dit dan in relatie tot patiënten met klachten van het bewegingsapparaat."

Meyboom-de Jong profileert een dergelijke consultatieve werkwijze bovendien voor de specifieke begeleiding van oudere patiènten in de huisartspraktijk. Het gebruik van contextuele informatie, de noodzakelijke aandacht voor co-morbiditeit, de zorg voor continü̈teit en de aandacht voor de communicatie tussen de verschillende behandelaars zijn hier volgens haar essentiële aspecten."

Uit de beschreven ervaringen komt algemeen naar voren dat gezamenlijke consultatie uiteindelijk kan leiden tot een betere samenwerking tussen huisarts en specialist en dat belemmeringen, ook bij aanwezige motivatie, voornamelijk op het terrein van tijdgebrek en ontbreken van honorering blijken te liggen.

De samenwerking tussen huisarts en verpleeghuisarts kent nog niet de ontwikkelingen die zich inmiddels voltrokken hebben binnen de relatie huisarts-medisch specialist.

Uit een inventariserend landelijk onderzoek naar de intensiteit van de samenwerking russen verpleeghuisartsen en huisartsen, dat wij voorafgaand aan dit onderzoek hebben uitgevoerd (1998), bleek dat, ondanks de actuele transmurale profilering van verpleeghuizen, de frequentie van contacten tussen huisartsen en verpleeghuisartsen in het kader van de verpleeghuisdagbehandeling, de consultatiefunctie en de substitutieprojecten in het algemeen laag is. ${ }^{*}$ Eerder onderzoek bevestigde bovendien dat de samenwerkingsrelatie nog voornamelijk een verwijsrelatic is. ${ }^{\nu}$ Desalniettemin blijkt de samenwerkingsintensiteit in transmurale projecten wel positief beinvloed te worden door het aanwezig zijn van samenwerkingsafspraken, door een gezamenlijke betrokkenheid bij de zorg en door een financiële prikkel voor de huisartsen. Daarenboven zou de samenwerkingsintensiteit groter zijn in minder verstedelijkte gebieden en wanneer deze gestalte krijgt vanuit verpleeghuizen, waarin de artsen een lagere klinische werklast hebben. ${ }^{*}$ 
In dit onderzoek is gepoogd een indruk te verschaffen over de invloed van diverse factoren op geconstateerde verschillen in continuïteit van medische zorg in de as huisarts - verpleeghuisarts.

Refererend aan het bovenstaande wordt hierbij in eerste instantie gedoeld op de continuilteit van medische zorg, die gekoppeld is aan de overdracht of transitie van patiënten. Transitie van patiënten vindt plaats bij opname in en ontslag uit het verplecghuis, de verplecghuisdagbehandeling of de substitutiezorg. Daarnaast wordt ten aanzien van het begrip continuïteit van medische zorg ook gedoeld op de gezamenlijke betrokkenheid van huisarts en verpleeghuisarts bij de daadwerkelijke zorg voor in het verpleeghuis opgenomen patiènten, waarvoor de verpleeghuisarts de medische eindverantwoordelijkheid draagt én die voor dagbehandelingspatiënten en substitutiepatiënten, waarvoor de medische eindverantwoordelijkheid in de regel bij de huisarts blijft liggen.

De vraagstellingen van het onderzoek betroffen:

1. In hoeverre is er continuïteit van medische zorg tussen huisartsen en verpleeghuisartsen bij patiënten die zijn of worden opgenomen in het verpleeghuis of die (gaan) deeinemen aan dagbehandeling of substitutiezorg?

2. Welke factoren spelen een rol bij eventueel gesignaleerde verschillen in continuïteit van medische zorg?

(") samengestelde zorg zorg die verleend wordt door een medisch, paramedisch en verpleegkundig team, dat een integrale behandeling, verpleging en begeleiding biedt, op grond van een met de patiènt en diens familie overeengekomen zorgplan. De regie en verantwoordeiijkheden m.b.t. de zorgverlening zijn hierbij goed geregeld (ref. 35).
In het onderzoek is uitgegaan van schema 1, dat een model voor de samenwerking huisarts-verpleeghuisarts bevat. Refererend aan de toekomstige situatie waarin, in het overgangsgebied tussen huisartsenzorg en intramurale verpleeghuiszorg, zoals aangegeven, in toenemende mate sprake zal zijn van een vraag naar samengestelde zorg $(*)$, die semimuraal, in de thuissituatie of in het verzorgingshuis geboden zal moeten worden, wordt in dit model uitgegaan van het gegeven dat, in de zorg voor ouderen en patiènten met een chronische ziekte, vanuit de huisarts en verpleeghuisarts, zoveel mogelijk gestreefd moet worden naar een situatie waarin optimale samenhang en continuïteit van zorg gerealiseerd worden.

Schema 1 toont dat verondersteld wordt dat er, naast de algemene invloed van

SCHEMA 1 Samẹnwerking huisartș-verplẹghuisarts, anolyșemodel

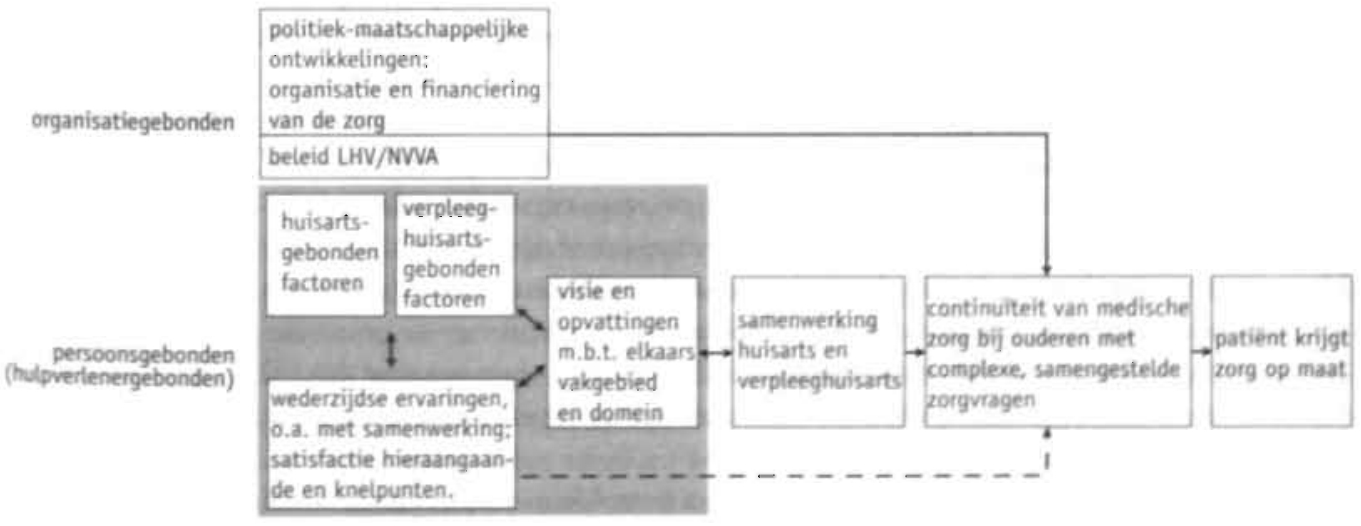


politiek-maatschappelijke ontwikkelingen op de zorg, een aantal hulpverlenergebonden factoren bij de huisarts en verpleeghuisarts zijn die, tesamen met de opgedane samenwerkingservaringen en de wederzijdse kennis van elkaars vakgebied, bepalen hoe hun onderlinge samenwerking zal verlopen. De aanname is dat een adequate samenwerking russen huisarts en verpleeghuisarts zal leiden tot een betere continuïteit van de medische zorgverlening en derhalve zal kunnen bijdragen aan zorg op maat voor de patiënt.

In relatie tot de samenwerking tussen huisarts en verpleeghuisarts stelt continuïteit van zorg daarmee dus eisen aan de communicatie (op tijd overleg); aan de overdracht (ook weer op het juiste moment en zowel kwantitatief als kwalitatief goed onderbouwd) en aan de afstemming (samen zorgverlenen, de zorg verdelen of de zorg in aanvulling op elkaar verlenen; complementariteit en taakafstemming dus). Uiteindelijk komen daarbij ook de regievoering, de coördinatie en de domeinconsensus aan de orde. ${ }^{13}$

\section{METHODE}

Onderzoeksgroep:

Om tot de definitieve totale onderzoeksgroep te komen heeft een twee-fasen steekproef plaatsgevonden. De eerste fase omvatte de selectie van een veertigtal verpleeghuizen op basis van een eerder door ons verricht onderzoek (par. 3.4), waarin de relatie tussen achtergrondkenmerken van verpleeghuizen en de samenwerkingsintensiteit tussen huisartsen en verpleeghuisartsen nagegaan werd. ${ }^{* 0}$ In de analyse van dat eerdere onderzoek werden allereerst de huizen geselecteerd, waarvan het meest te verwachten was dat er een intensieve samenwerking tussen huisartsen en verpleeghuisartsen zou zijn. Dat waren alle verpleeghuizen die naast een consultatiefunctie, dagbehandelingsplaatsen en substitutie-projecten hebben. Daarna werden uit die groep twee extreme groepen verpleeghuizen geselecteerd, respectievelijk verpleeghuizen die niet-intensief samenwerken met huisartsen (groep $X: n=37$ ) en verpleeghuizen die intensief samenwerken met huisartsen (groep $Y: n=40$ ), waarbij de criteria voor intensieve samenwerking waren, dat de verpleeghuisartsen minstens maandelijks contact met huisartsen moesten hebben in het kader van de dagbehandeling en de consultatiefunctie, terwijl dit voor de nauwelijks samenwerkende huizen hoogstens enkele malen per jaar mocht zijn. ${ }^{\text {*6 }}$ Voor het onderhavige onderzoek werden uit die beide onderscheiden groepen $\mathrm{X}$ en $Y$ van het eerdere onderzoek, elk 20 verpleeghuizen gekozen $(=2$ vervolggroepen $\mathrm{XI}_{1}(20)^{*}$ en $\mathrm{YI}(20)^{*} ; \mathrm{n}=40$ totaal), waarbij gelet werd op een gelijke verdeling van de urbanisatiegraad, omdat deze in het eerdere onderzoek de belangrijkste verschilfactor was.

Van de zo geselecteerde verpleeghuizen zijn vervolgens ( $=2 \mathrm{e}$ fase van de steekproef), per verpleeghuis, alle verpleeghuisartsen (totaal: 137; gemiddeld 3-4/ verpleeghuis) en een twintigtal huisartsen uit de respectievelijke adhaerentiegebieden van elk van deze verpleeghuizen in de steekproef opgenomen.

Het verzorgingsgebied per verpleeghuis, waaruit willekeurig 20 huisartsen geselecteerd werden, kwam als volgt tot stand: uitgegaan werd van de postcoderegio (eerste 3 cijfers) van het verpleeghuis. Indien in deze regio minder dan 20 huisartsen praktiserend waren, werd de regio vervolgens uitgebreid met aangrenzende postcoderegio's.

Indien een huisarts geen ervaring had met het betrokken verpleeghuis, werd
* Groep X1:

in tekst worden deze verpleeghuizen veelal angeduid als 'nietintensief samenwerkende verpleeghuizen:

* Groep Y1:

in tekst veelal aangeduid ats intensief samenwerkende verpleeghuizen: 
gevraagd de vragenlijst oningevuld terug te sturen. Dan werd een andere huisarts uit het verzorgingsgebied in de steckproef opgenomen. De uiteindelijke huisartsensteekproef bestond uit 780 huisartsen.

Aan de geselecteerde artsen werd een uitvoerige schriftelijke huisartsen- danwel verplecghuisartsenenquête voorgelegd.

Voor de verwerking van de enquête konden vervolgens 4 groepen respondenten worden onderscheiden:

\section{Met betrekking tot de huisartsenenquête:}

- groep I: de groep huisartsen behorende tot de verzorgingsgebieden van de groep verpleeghuizen (groep X1) waarvan geen intensieve samenwerking met huisartsen verwacht mocht worden;

- groep II: de groep huisartsen behorende tor de verzorgingsgebieden van de groep verpleeghuizen (groep $\mathrm{Y}_{1}$ ) waarvan wel cen nauwe samenwerking met huisartsen verwacht mocht worden;

Met betrekking tot de verpleeghuisartsenenquête:

- groep A: de groep verpleeghuisartsen van de groep verpleeghuizen (groep X1) waarvan geen intensieve samenwerking met huisartsen verwacht mocht worden;

- groep B: de groep verpleeghuisartsen van de groep verplecghuizen (groep YI) waarvan wel een nauwe samenwerking met huisartsen verwacht mocht worden.

\section{Meetinstrument:}

Zowel de enquête voor de huisartsen. (64 vragen), als de enquête voor de verpleeghuisartsen ( 57 vragen) bestond uit 4 rubrieken:

1. Achtergrondgegevens: w.o. vragen over leeftijd, geslacht, kenmerken van de praktijksituatie (ook gerelateerd aan de doelgroep van oudere patiènten), persoonskenmerken (ervaring, kennis en arbeidssatisfactie) en of men in het verleden wel eens kennis had gemaakt met het werk van de andere medische discipline.

2. Samenwerking algemeen: 2 vragen over de frequentie van onderlinge werkcontacten rondom het betrokken verpleeghuis (4-puntsschaal: variërend van vaak tot nooit) en over de beoordeling van de samenwerking in algemene zin, rondom het betreffende verpleeghuis (wederom 4-puntsschaal: van goed tot slecht).

3. Ervaringen van huisarts, respectievelijk verpleeghuisarts gerelateerd aan de verschillende verpleeghuisfuncties. In deze rubriek van beide enquêtes werden een viertal praktijkcasussen gepresenteerd over, achtereenvolgens, een patiënt die in het verpleeghuis opgenomen wordt, over een pariènt die de dagbehandeling bezoekt, over een pariënt in een substitutieproject en over cen patiënt waarvoor de verpleeghuisarts door de huisarts in consult geroepen wordt:

De respondenten moesten er bij de beantwoording van uitgaan dat de gepresenteerde pariënten als het ware hun eigen patiënten waren én dat het om het verpleeghuis ging, rondom welk zij voor de enquête geselecteerd waren.

Als men geen praktijkervaring had met patiēnten, gerelateerd aan de in de 
casuïstiek gepresenteerde verpleeghuisfuncties, dan mocht men de betreffende casus overslaan.

Met het oog op de vraagstellingen van dit onderzoek werd in de casusvragen aandacht besteed aan de frequentie van persoonlijke werkcontacten, die gerelateerd waren aan de overdrachts-of transitiemomenten in de zorg (met antwoorden variërend in 5-puntsschaal van nooit tot altijd). Het betrof hier dus de mate van interdisciplinair contact tussen huisarts en verpleeghuisarts bij opname in, respectievelijk ontslag uit het verpleeghuis, de verpleeghuisdagbehandeling en de substitutiezorg. Ook werd in dit verband aandacht besteed aan de onderlinge afstemming van de zorg ten behoeve van in het verpleeghuis opgenomen pariënten en van patiënten die zorg ontvingen op de dagbehandeling en in substiturieprojecten.

Uiteindelijk zou daarmee een indruk verkregen kunnen worden van de mate van continuïteit van medische zorg tussen huisarts en verpleeghuisarts.

In deze rubriek werd ook gevraagd naar het oordeel over de samenwerking in relatie tot de betreffende verpleeghuisfuncties (4-puntsschaal van goed tot slecht).

4. Opvattingen over domein, samenwerking en samenwerkingsknelpunten. In de vierde rubriek vragen werd bij de huisartsen en verpleeghuisartsen een aantal opvattingen over samenwerking getoetst (5 antwoordcategorieën varièrend van zeer mee eens tot zeer mee oneens).

Tevens werd nagegaan welk belang door beiden gehecht wordt aan de samenwerking met verschillende hulpverlenende disciplines in de ouderenzorg en werd nagegaan welke knelpunten een rol spelen in de onderlinge samenwerking.

Voor deze laatste twee items varieerden de antwoorden van belangrijk tot niet belangrijk, respectievelijk van belangrijk knelpunt tot geen knelpunt ( $2 \mathrm{x}$ een 4-puntsschaal).

\section{Analyses:}

In de analyse zijn de huisartsen-enquête en de verpleeghuisartsen-enquête separaat en naar volgorde van de enquêterubrieken uitgewerkt. Ten aanzien van de huisartsen-enquête zijn steeds de 2 onderscheiden groepen huisartsen vergeleken, groep I en Iİ; bij de verpleeghuisartsen-enquête betrof dit de groepen A en B.

Om de validiteit van het selectieproces in dit onderzoek, met betrekking tot de onderscheiden respondentgroepen, te toetsen, werd nagegaan of het, in ons eerder verrichte onderzoek, getraceerde verschil in samenwerking vanuit de 2 groepen verpleeghuizen $\mathrm{X}$ en $\mathrm{Y}$ ook bevestigd kon worden door de hier onderscheiden groepen huisartsen, respectievelijk verpleeghuisartsen. Dit geschiedde enerzijds op basis van de, in dit onderzoek, aangegeven onderlinge contactfrequentie en anderzijds op basis van het oordeel over de samenwerking, in algemene en specifieke zin. Hierbij werd gebruik gemaakt van Chi-kwadraattoetsen.

Bij de verwerking van de gegevens uit de twee enquêtes werd daarna gekeken in hoeverre er sprake was van een persoonlijk overdrachtscontact en zorgafstemmingscontact tussen huisarts en verpleeghuisarts in relatie tot de verschillende verpleeghuisfuncties (enquêterubrick casuïstiek).

Uiteraard werden hiervoor, met het oog op de hoofdvraagstellingen, weer groep I en II respectievelijk A en B met elkaar vergeleken. De verwachting was dat een nauwe samenwerking tussen huisartsen en verpleeghuisartsen rondom intensief 
samenwerkende verpleeghuizen, ook aanleiding zou zijn tot een betere continuilteit van medische zorg. Toetsing vond plaats via Chi-kwadraattoetsen.

De groepenvergelijking startte vervolgens in beide gevallen met het nagaan van eventuele verschillen ten aanzien van de achtergrondkenmerken. Mogelijk zou dit al informatie kunnen opleveren over het eerder gevonden verschil in samenwerkingsintensiteit vanuit de twee onderscheiden groepen verpleeghuizen. Hierbij werd in de toetsing gebruik gemaakt van Chi-kwadraattoetsen (bij variabelen gemeten op nominaal niveau) en van Student's t-toetsen (bij variabelen gemeten op interval/ratio niveau).

Tenslotte werd getracht om vanuit beide enquêtes achtereenvolgens een indruk te krijgen van de opvattingen van de respondenten met betrekking tot het domein en de samenwerking in de zorg, over het belang dat gehecht wordt aan de samenwerking met verschillende andere hulpverleners en over het belang van een aantal knelpunten in relatie tot de onderlinge samenwerking. In feite betrof het hier de algehele samenwerkingsattitude. Eventucle verschillen zouden eveneens een verklaring kunnen geven voor gevonden verschillen in samenwerkingsintensiteit, samenwerkingsoordeel en continuilteit van medische zorg. De groepenvergelijking vond opnieuw plaats door gebruik te maken van Chi-kwadraattoetsen en Student's t-toetsen.

Aangezien te verwachten was dat zowel de respons van de verpleeghuisartsen per verpleeghuis als die van de huisartsen per adhaerentiegebied zou variëren, werd in de resultaten bij alle analyses een wegingsprocedure toegepast. Daarmee was gewaarborgd dat de inbreng per verpleeghuis en per verzorgingsgebied een even groot aandeel zou krijgen.

\section{RESULTATEN}

HUISARTSEN-ENQUÊTE:

Er werden 249 bruikbare vragenlijsten retour ontvangen; 124 van huisartsen gerelateerd aan niet-intensief samenwerkende verplecghuizen (groep I) en 125 van huisartsen gerelateerd aan intensief samenwerkende verpleeghuizen (groep II). De bruikbare respons op de huisartsen-enquête bedroeg daarmee $31,9 \%$ (249 van de 780 vragenlijsten).

Op basis van de beschikbare gegevens leverde de non-responsanalyse geen significante verschillen op tussen de groep responders en non-responders, voor wat betreft het geslacht, de praktijkvorm, de vestigingsduur en de urbanisatiegraad.

\section{Aangegeven contactfrequentie en oordeel over de samenwerking:}

Om na te gaan of de oorspronkelijke verdeling in niet-intensief en intensief samenwerkende verpleeghuizen correct was geweest, werd ten aanzien van beide onderscheiden groepen huisartsen nagegaan wat de frequentie van hun werkcontacten met de betrokken verplecghuizen was.

Hieruit bleek dat huisartsen uit de verzorgingsgebieden van de niet-intensief samenwerkende verpleeghuizen (groep I) in 78,5\% zelden tot nooit werkcontacten met de betrokken verpleeghuizen hadden, in $19,8 \%$ was dit af en toe het geval en in $1,7 \%$ vaak. Bij de huisartsen uit de verzorgingsgebieden van de intensief samenwerkende verpleeghuizen (groep II) lagen deze percentages achtereenvolgens op: $51,2 \%, 42,8 \%$ en $6 \%$. Daarmee hadden huisartsen uit groep II significant vaker contact met hun verpleeghuizen ( $\left.X^{\prime} ; p=0,000\right)$. 
De beoordeling door beide groepen huisartsen van de samenwerking met het verpleeghuis in het algemeen en ten aanzien van de verschillende verpleeghuisfuncties is weergegeven in tabel $\mathrm{I}$.

Met uitzondering van de contacten in relatie tot de consultatiefunctie blijken huisartsen uit groep II de samenwerking in het algemeen en in relatie tot pariènten die opgenomen worden in respectievelijk het verpleeghuis, op de verpleeghuisdagbehandeling en in substitutieprojecten, significant vaker als redelijk, tot goed te beoordelen dan huisartsen uit groep I (zie p-waarden tabel 1).

Het in dit verband gevonden procentuele verschil bij de consultatiefunctie mag echter, met het oog op de hoogte van de respons hieraangaande, ook als betekenisvol gekenschetst worden.

Uit de tabel blijkt ook dat minder goede samenwerking vooral tot uiting komt in transmurale functies van het verplecghuis en dan met name de dagbehandeling en de substitutieprojecten. De percentages spreken verder voor zich.

\section{Continuiteit van medische zorg:}

Tabel $2 \mathrm{a}, 2 \mathrm{~b}$ en $2 \mathrm{c}$ geven inzicht in de mate van contact tussen huisarts en verplecghuisarıs, bij opname, tijdens opname en bij ontslag van een patiënt van het verpleeghuis, van de dagbehandeling en de substitutiezorg (= continuïteit van medische zorg).

In beide groepen huisartsen heeft meer dan de helft nooit contact met de verpleeghuisarts bij opname van een patiènt in het verpleeghuis (tabel 2a). 25,5\% van de huisartsen uit groep I geeft aan dat ze bij meer dan de helft van de opnames wel contact met de verpleeghuisarts hebben. In groep II is dat $30,6 \%$. Dit betreft geen significant verschil. Significante verschillen zijn er wel ten aanzien van de contacten met de verpleeghuisarts bij start van de dagbehandeling en van substitutiezorg. Huisartsen uit groep II geven achtereenvolgens in $43,8 \%$ en $44,8 \%$ aan dat ze in meer dan de helft van de gevallen contact met de verpleeghuisarts opnemen als een van hun patiënten start met dagbehandeling danwel substituriezorg. Dit is significant vaker dan dat gebeurt door huisartsen van groep 1. Desalnietremin heeft eenderde van de huisartsen uit groep II en ruim de helff van de huisartsen uit groep I nooit contact met de verpleeghuisarts bij opname van een patiënt in deze twee verpleeghuisfuncties (tabel 2a).

Alle huisartsen uit beide groepen (groep 1: 99,1\% en groep II 99,4\%) geven aan dat ze bij opname van hun patiënten in het verpleeghuis, in meer dan de helft van de gevallen standaard hun medische gegevens opsturen naar het verpleeghuis. Bii dagbehandelingspatiënten liggen deze percentages lager (groep I: 77,1\%; groep II: $87,7 \%)$. Ten aanzien van substitutiepatiënten geven de huisartsen uit groep I in $65,0 \%$ en uit groep II in $80,6 \%$ hun gegevens aan de verpleeghuisarts ter inzage. Deze procentuele verschillen zijn overigens niet statistisch significant, ook al lijki de rendens bii groep Il te zijn dat een en ander vaker gebeurt.

Tabel 26 geeft inzicht in de mate van persoonlijk contact (al dan niet telefonisch), tussen huisarts en verpleeghuisarts ten behoeve van patiènten die opgenomen zijn in het verpleeghuis, op de dagbehandeling of in substitutiezorg.

We constateren dat, ten aanzien van alle drie verpleeghuisfuncties, een substantieel deel van de huisartsen uit beide groepen hier nooit contact heeft met de verpleeghuisarts. De percentages van de huisartsen uit groep II tenderen wel naar een frequenter contact. Ten aanzien van in het verpleeghuis en op de dagbehandeling 
opgenomen patiënten betreft het deels significante verschillen; de niet-significante verschillen mogen wel als betekenisvol gekenmerkt worden.

Tabel $2 \mathrm{c}$ geeft inzicht in de mate van overdrachtscontact bij ontslag van een patiënt uit de eerder genoemde drie verpleeghuisfuncties. In beide groepen is de frequentie van het contact bij ontslag in het algemeen hoger dan bij opname in deze verpleeghuisfuncties. Bij huisartsen uit groep II is dit echter significant vaker het geval, daar, waar het ontslagen patiènten betreft vanuit het verpleeghuis en de verpleeghuisdagbehandeling. Veruit de meeste huisartsen van beide groepen ontvangen in de regel ook ontslagbrieven van de verplecghuisarts.

\section{Achtergrondkenmerken:}

De gemiddelde leeftijd van de huisartsen uit groep I was 46,7 jaar (sd 7,0) en in. groep II 47,1 jaar (sd 6,8). De geslachtsverdeling man/vrouw was zowel in groep I als groep II 9:1. Ten aanzien van leeftijd en geslacht waren er geen significante verschillen tussen beide groepen.

Het gemiddeld aantal dagdelen dat men formeel in de praktijk werkzaam is, was in beide groepen 8,9; het aantal uren dat men daadwerkelijk met de praktijkvoering bezig is, was ook niet significant verschillend en bedroeg in groep I 47,6 uur (sd 14,6) en in groep II 45,9 uur (sd 15,0). In beide groepen waren de huisartsen gemiddeld 15 jaar werkzaam in de actuele praktijksituatie en waren er tussen beide groepen geen significante verschillen in gemiddelde praktijkgrootte en type praktijk (van solist tot gezondheidscentrum) en in het percentage 65--ers en 80 +-ers in de eigen praktijk. In beide groepen gold dat het afgelopen jaar per huisarts gemiddeld 4 tot 5 patiënten in de betrokken verpleeghuizen werden opgenomen. Er startten in diezelfde periode per huisarts gemiddeld ongeveer evenveel patiënten met dagbehandeling en er werden per huisarts gemiddeld 3 tot 4 patiënten in een substitutieproject opgenomen. Hieraangaande waren dus ook. geen verschillen tussen beide groepen traceerbaar. Datzelfde gold voor beide groepen met betrekking tot het gemiddeld aantal verzorgingshuispatiënten per huisarts. In groep I en II had een everi groot deel van de huisartsen tijdens of na de huisartsopleiding wel eens een tijdje in een verpleeghuis gewerkt, namelijk eenderde deel. Ten aanzien van de arbeidssatisfactie, gerelateerd aan de medische zorg voor ouderen, bleek ongeveer de helft van de huisartsen van beide groepen (groep I: $47,3 \%$ en groep II 45,2\%) tenminste eenmaal per maand het idee te hebben dat men meer tijd in de relatie met oudere patiënten investeert dat dat men er in de vorm van waardering voor terugkrijgt. Tweevijfde deel zou dit idee een paar maal per jaar hebben. Evenzo werden geen significante verschillen aangetoond met betrekking tot de door huisartsen van beide groepen ervaren inhoudelijke leemtes ten aanzien van de medische zorg aan ouderen. In groep I bleek $26,0 \%$ en in groep II $33,9 \%$ bij zichzelf leemtes te ervaren met betrekking tot de kennis van de geriatrie. Bij respectievelijk $74,0 \%$ en $66,1 \%$ was dat niet het geval. De helft van beide groepen huisartsen (gr.I: $55,4 \%$, gr.II: 47.3\%) gaf aan te weinig kennis te hebben van de mogelijkheden van andere zorgaanbieders. Datzelfde gold voor de kennis omtrent indicatie- en zorgtoewijzingsprocedures: gr.I: $53,5 \%$, gr.II: $51,9 \%$. Het merendeel van de huisartsen in beide groepen gaf bovendien aan onvoldoende kennis te hebben van de wetgeving op het gebied van de zorg (gr.I: $75,8 \%$, gr.2: $81,3 \%$ ). 


\section{Samenwerkingsattitude:}

Door middel van een rwaalftal stellingen werd bij de huisartsen uir beide groepen nagegaan wat hun visie was op de samenwerking met de verpleeghuisarts in de zorg voor ouderen. In tabel 3 zijn deze stellingen weergegeven met de onderscheiden percentages van beide groepen. De helft tot meer dan de helft van de huisartsen uit beide groepen blijkt het merendeel van deze stellingen in grote lijnen te onderschrijven. Terughoudendheid bestaat ten aanzien van de stellingen $\mathrm{f}$ en $\mathrm{g}$, betreffende de medische zorg in verzorgingshuizen. Significante verschillen tussen groep I en II bestaan er met betrekking tot stelling $\mathrm{d}$ en $\mathrm{e}$.

Huisartsen uit groep. II zien het verpleeghuis meer als expertisecentrum in de ouderenzorg en vinden de deskundigheid van de verpleeghuisarts vaker onmisbaar dan huisartsen uit groep 1 .

Eveneens werd aan de huisartsen van beide groepen gevraagd in hoeverre men belang hecht aan de samenwerking met andere hulpverleners in de ouderenzorg. Van de huisartsen uit groep I en II vonden respectievelijk $44,9 \%$ en $70,1 \%$ de samenwerking met de verpleeghuisarts belangrijk. Voor andere disciplines waren de percentages op de score "belangrijk" in groep I en II achtereenvolgens: wijkverplecgkundige: $96,7 \%$ en $96,5 \%$; maatschappelijk werkende: $47,6 \%$ en $53.1 \%$; gezinsverzorgende: $49,8 \%$ en $55,2 \%$; apotheker: $50,8 \%$ en $51,1 \%$; eerstelijns-fysiotherapie: $68,8 \%$ en $63,8 \%$; medisch specialist: $75,6 \%$ en $63,9 \%$ en medewerker RIAGG: $85,7 \%$ en $73,6 \%$. Slechts de procentuele verschillen die gevonden werden t.a.v. het belang dat gehecht wordt aan de samenwerking met de verpleeghuisarts en met de RIAGG waren significant verschillend ( $\mathrm{p}$-waarden op basis van $\mathrm{X}^{2}$-toets resp. 0,000 en 0,028).

\section{Samenwerkingsknelpunten:}

Tenslotie werd aan de huisartsen gevraagd een oordeel te geven met betrekking tot het belang van een aantal knelpunten in relatie tot de onderlinge samenwerking met de verpleeghuisarts. Tabel 4 toont de geregistreerde percentages van beide responsgroepen.

Alle knelpunten, zoals genoemd in deze tabel, spelen een zekere rol, waarbij voor beide groepen met name de wachtlijstproblematiek van het verpleeghuis belangrijk is (gr: 1: $71,7 \%$ en gr. Il: $83,8 \%$ ). De procentuele cijfers van beide groepen met betrekking tot dit knelpunt zijn hierbij bovendien significant verschillend. 


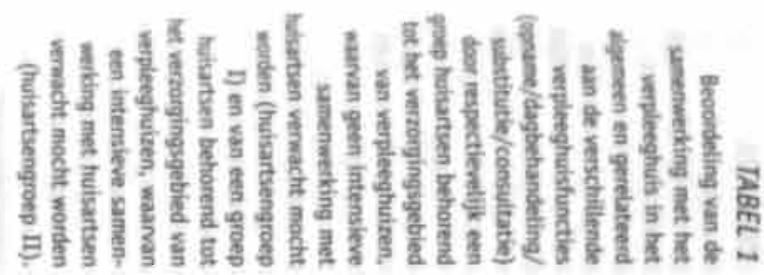

Beoondelingscategonie:

Algeneen

In relatie tot in verpleeghuis apgenomen patiênten

\section{Aantal huisarts}

respondenten

$N=218$ (totaal)

Uit groep $\mathrm{I}=10 \mathrm{6}$

$N=216$ (totaal)

Uit groep $1=105$

Uit groep II - 111

Uit groep II - 114

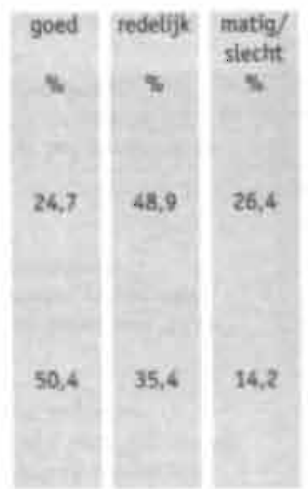

$p=0,000$

19so $x^{2}$-toets:

2. waarde $>0.05$

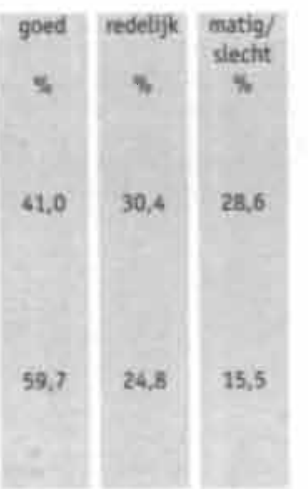

$p=0,014$
In relatie tot potiênten vart de dagbehandeling
In reiotie tot patienten in substitutieproject

\section{$N=117$ (totaal)}

Uit groep I $=51$

Uit groep II $=66$

Uit groep II = 104

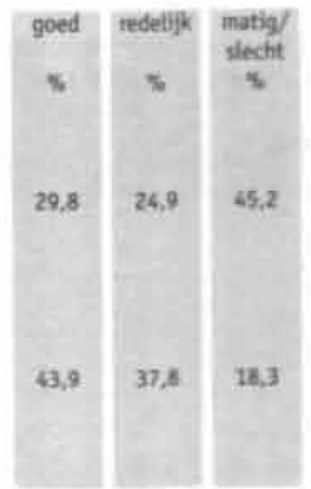

$p=0,000$

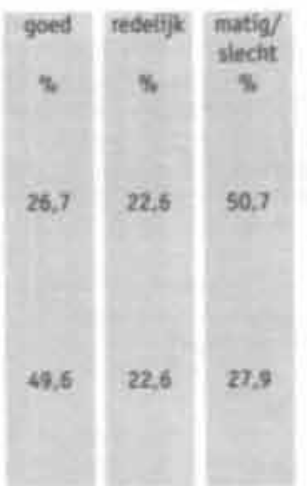

$p=0.020$
In relatie tot consultatien contocten over potienten

\section{$N=103$ (totaal)}

Uit groep $\mathrm{I}=36$

Uit groep II $=67$

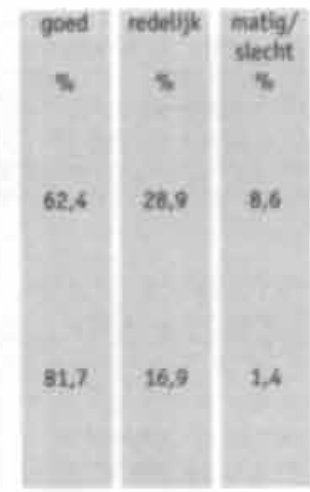

$p=0,053$

De verschillen in $\mathrm{N}$ zijn terug te voeren op twee aspecten: a) sorns hadden enkele respondenten uit beide groepee een vaag niet ingevild; in b) ais men geen ervaring had met een verpleeghuisfunctie mocht men de betreffende sectie in de enquete overslaar. 
Contact bij opname patienten in het verpleaghuis

Contact bi start doghehondeling von kx! putient

$\mathrm{N}=200$

Uit groep $1=96$

Uit groep II - 104

Lit groep II = 118

Contactintensiteit ( 3 categorieèn) d.m.v. procentuele verdeling van het aantal betrokken huisartsen

Groep I:

Groep huisartsen behorende tot de verzorgingsgebieden van de niet. intensief samenwerkende verpleeghuizen

Groep II:

Groep huisartsen behorende tot de verzorgingsgebieden van de

intensief samenwerkende

verpleeghuizen

ns: $X^{2}: p$-waarde $>0,05$

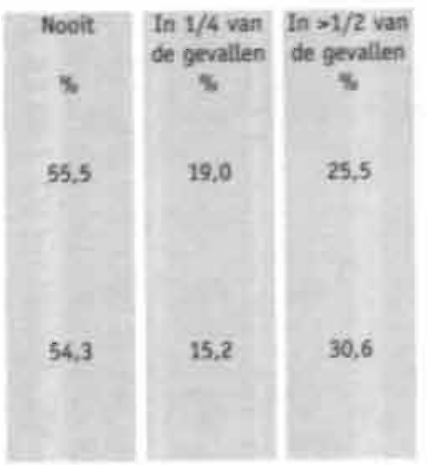

$p=0,602$

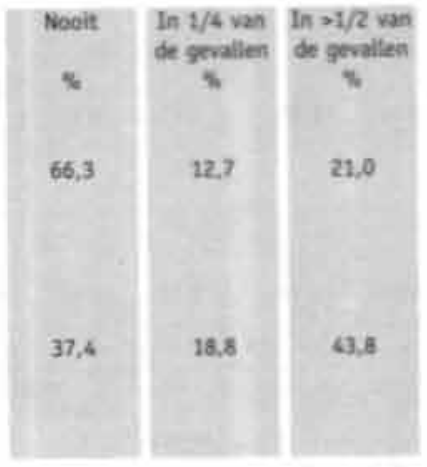

$p=0,000$
Contact L A. . patienten ori stort substiturienorg

\section{$x=125$}

Uit groep I $=58$

Uit groep II - 5 ?

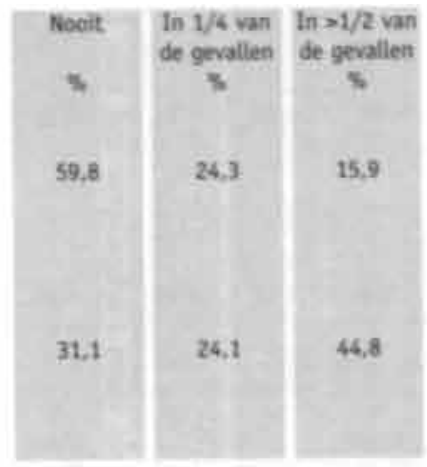

$p=0,000$

De verschillen in $\mathrm{N}$ zijn terug te voeren op twee aspecten: a) soms hadden enkele respondenten uit beide groepen een vaag niet ingevuld: én b) als men geen ervaring had met cen verpleeghuisfunctie mocht men de betreffende sectie in de enquéte overstaan.

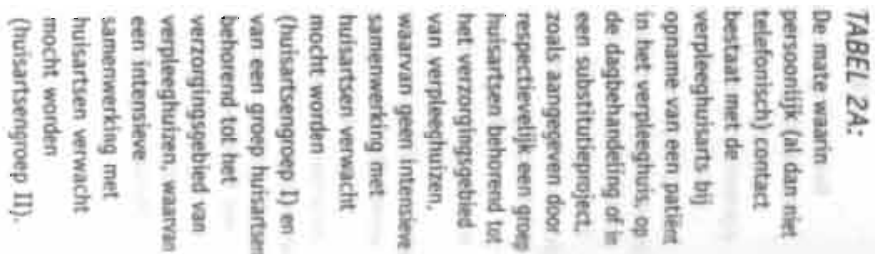


TABEL 28:

De mate waarin persoonlijk (al dan niet telefonisch) contact bestaat met de verpieeghuisarts tijdens opname van een patient in het verpleeghuis, op de dagbehandeling of in een substitutieproject. zoals aangegeven doos respectievelijk een groep huisartsen behorend tot het verzorgingsgebied van verpleeghuizen, warvan geen intensieve samenwerking met huisartsen verwacht mocht worden (huisartsengroep I) en van een groep huisartsen behorend tot het verzorgingsgebied van verpleeghuizen, warvan een intensieve samenwerking met huisartsen verwacht mocht worden (buisartsengroep II).
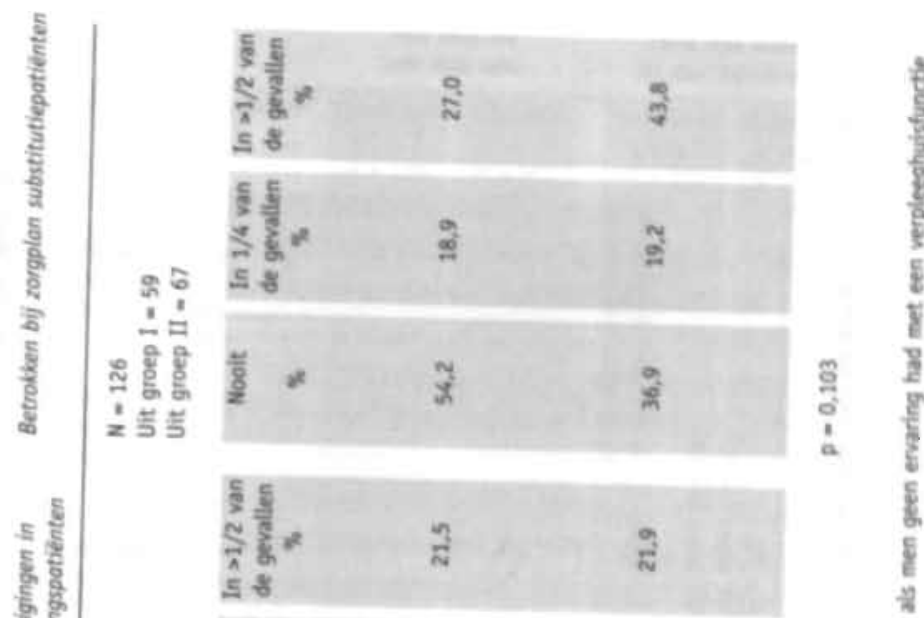

흥

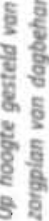
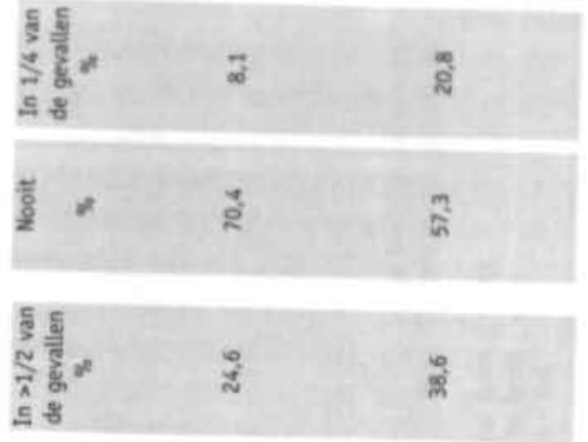

홍ㅎํ

के

몬 홈

응

윤 है

8 क्ष

$-\overline{0}$

$\therefore=$

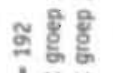

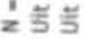

5

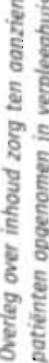

总总

동 될

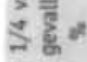

도 항

$\infty$
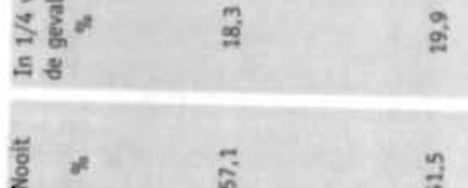

E

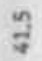

돈

대요

도 융

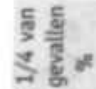

कै

$\stackrel{m}{2}$

을 5 ㄴํㄴ

$\because \dot{1}$

을

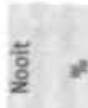

กำ

mi

ב

2

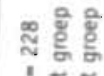

$\frac{1}{z} \overline{5}$

部

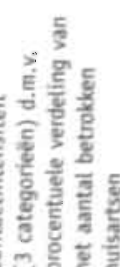

를 है है

竞

\&

औ

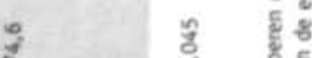

है

.

है है

$\stackrel{8}{\circ}$ 
TABEL 2C:

De mate waarin persoonlijk (al dan niet telefonisch) contact bestaat met de verpleeghuisarts bij ontslag van een patient vit het verpleeghuis, uit de dagbehandeling of uit een substitutieproject, zoals aangegeven door respectievelijk een groep huisartsen behorend tot het verzorgingsgebied van verpleeghuizen, waarvan geen intensieve samenwerking met huisartsen verwacht mocht worden (huisartsengroep I) en van een groep huisartsen behorend tot het verzorgingsgebied van verpleeghuizen. waarvan een intensieve samenwerking met huisartsen verwacht. mocht worden (huisartsengroep II).
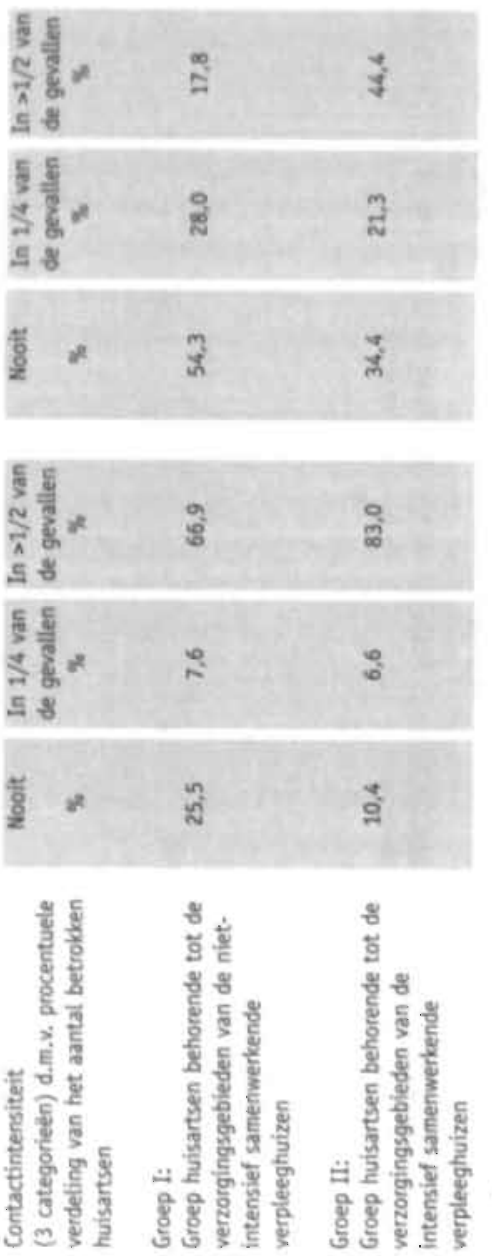

ㅎํㅁ 
TABEL 3

De visie met betrekking tot de samenwerking met de verpleeghuisarts in de zorg voor ouderen, door een groep huisartsen behorend tot het verzorgingsgebied van verpleeghuizen, earvan verwacht mocht worden dat ze niet intensief samenwerken met verpleeghuisartsen (huisartsengroep I) respectievelijk door een groep huisartsen behorend tot het verzorgingsgebied van verpleeghuizen, waarvan een intensieve samenwerking met huisartsen verwacht mocht worden (huisartsengroep II)

(ns: $x^{2}$; p-warde $>0,05$ )
Bent $u$ het cens met de volgende stellingen?

a. Een patiềnt uit mijn praktijk, die definitief in een verpleeghuis: opgenomen is, beschouw ik niet meer ats mijn patient

b. Ik wil graag betrokken blijven bij de behandeling van mijn patiènten, die ter revalidatie in het verpleeghuis zijn opgenomen

c. I k kan het beste zelf bepalen wanneer ik het tijd acht om een traject van consultatie door de verpleeghuisarts in te zetten

d. Ik zie het verpleeghuis ats een expertisecentrum op het gebied van de ouderenzorg

e. De ontwikketingen in de ouderenzorg maken de deskundigheid van de verpleeghuisarts voor mij onmisbaar

f. De medische zorg in verzorgingshuizen kan m.i., met het oog op de groeiende zorgvraag, aldaar, beter overgenomen worden door de verpleeghuisarts

9. De verpleeghuisarts zou volgens mij een rol kunnen spelen bij het regisseren van de zorgverlening in het verzorgingshuis

h. Het verdient aanbeveling dat hagro's (huisartsengroepen), met betrekking tot het optimaliseren van de te verrichten taken op het gebied van de ouderenzorg. gebruik maken van een verpleeghuisarts als consulent.

i. De samenwerking tussen huisarts en verpleeghuisarts kan worden bevorderd. door het gezamenlijk ontwikkelen van standaarden voor de medische zorg voor ouderen

j. De samenwerking tussen huisarts en verpleeghuisarts kan worden bevorderd door het geven van aandacht aan de wederzijdse beroepsinhoud in de basisen vervolgopleidinger

k. De samenwerking tussen huisarts en verpleeghuisarts kan worden bevorderd door het samen ontwikkelen en volgen van bij- en nascholing

L. De huidige wet- en regelgeving, de tarief-en honoreringsstructuur en de werkwijze van de indicatiecommissies e.d.. staan de samenwerking tussen de huisarts en de verpleeghuisarts in de weg
Mre eens tot

Deets mee oneens

tot zeer mee oncens

ingarde

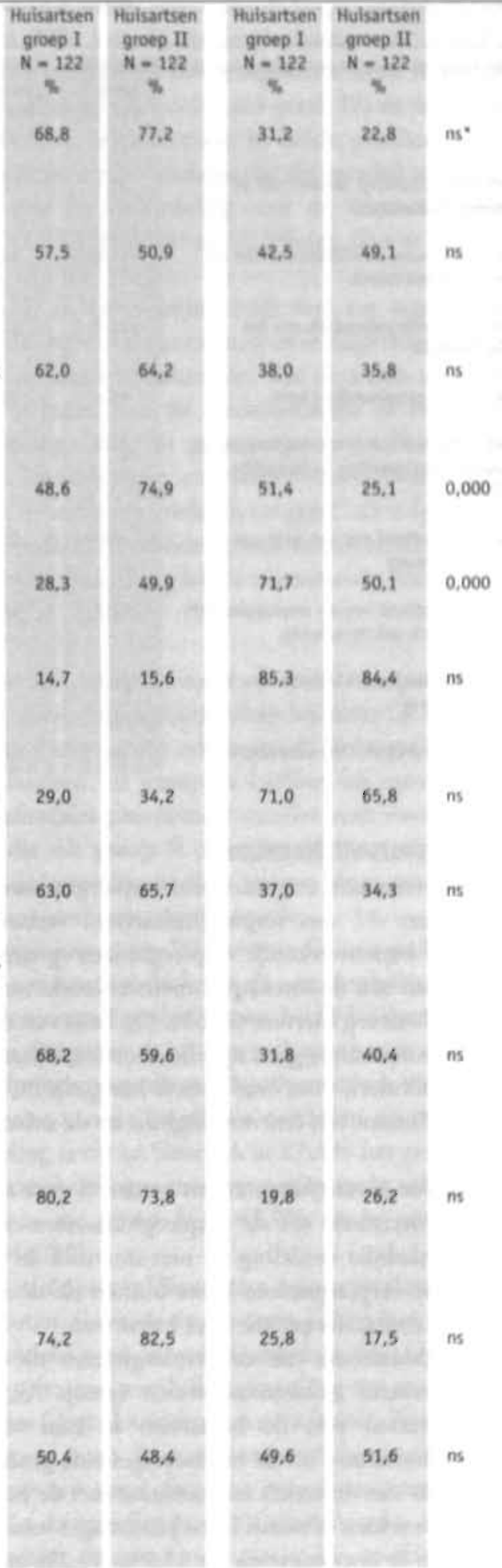




\begin{tabular}{|c|c|c|c|c|c|}
\hline & \multicolumn{2}{|c|}{ Belangrijk kneipunt } & \multicolumn{2}{|c|}{$\begin{array}{l}\text { Minder belangrijk } \\
\text { tot geen knelpunt }\end{array}$} & $\begin{array}{l}\text { p- } \\
\text { waarde }\end{array}$ \\
\hline Een knelpunt in de samenwerking kan zijn: & $\begin{array}{l}\text { Huisartsen- } \\
\begin{array}{c}\text { groep I } \\
N=122 \\
\%\end{array}\end{array}$ & $\begin{array}{c}\text { Hulsartsen- } \\
\text { groep II } \\
\mathrm{N}=122 \\
\%\end{array}$ & $\begin{array}{c}\text { Huisartsen- } \\
\text { groep } 1 \\
N=122 \\
\%\end{array}$ & $\begin{array}{l}\text { Huisartsen- } \\
\begin{array}{c}\text { groep II } \\
N=122 \\
\%\end{array}\end{array}$ & \\
\hline $\begin{array}{l}\text { Het niet persoonlijk kennen van de } \\
\text { verpleeghuisarts(en) }\end{array}$ & 31,3 & 31,3 & 68,7 & 68,7 & ns: \\
\hline $\begin{array}{l}\text { De telefonische bereikbaarheid van de } \\
\text { verpleeghuisarts(en) }\end{array}$ & 15,4 & 16.7 & 84,6 & 83.3 & ns \\
\hline $\begin{array}{l}\text { De wachtilistproblematiek van het } \\
\text { verpleeghuis }\end{array}$ & 71,7 & 83,8 & 28.3 & 16,2 & 0.034 \\
\hline De tijd die samenwerking kost & 45,6 & 38.8 & 54,4 & 61,2 & ns \\
\hline $\begin{array}{l}\text { Het ontbreken van een extra vergoeding } \\
\text { voor de samenwerking (- financiele } \\
\text { prikkel) }\end{array}$ & 23,2 & 19.4 & 76,8 & 80,6 & ns \\
\hline $\begin{array}{l}\text { De onbekendheid met het werk van de } \\
\text { verpleeghuisarts }\end{array}$ & 9,5 & 10,7 & 90,5 & 89,3 & ns \\
\hline $\begin{array}{l}\text { De onbekendheid van de verpleeghuisarts } \\
\text { met het werk van de huisarts }\end{array}$ & 12,8 & 12,0 & 87,2 & 88,0 & ns \\
\hline $\begin{array}{l}\text { Het ontbreken van richtlijnen voor de } \\
\text { samenwerking }\end{array}$ & 22,6 & 26.2 & 77,4 & 73,8 & ns \\
\hline De expansiedrift van het verpleeghuis & 18,7 & 17,3 & 81,3 & 82.7 & ns \\
\hline
\end{tabular}

De mate waarin ? onderscheiden groepen huisartsen

respectievelijk de groe; huisartsen behorend tot het verzorgingsgebied van verpleeghuizer waarvan geen intensieve samenwerking met huisartsen verwach mocht worden (huisartsengroep I) en de groep huisartser behorend tot het verzorgingsgebied van verpleeghuizen waarva: een intensieve samenwerking met huisartsen verwach mocht worde: (huisartsengroep II) knelpunten in relatie tot de onderting: samenwerking met de verpleeghuisartsen belangrijk vinden.

(ns: $\mathrm{X}^{2}$; p-waarde $>0,05$ )

De expansiedrift van het verpleeghuis

\section{VERPLEEGHUISARTSEN-ENQUETE:}

Van de verzonden enquêtes naar verpleeghuisartsen $(n=137)$ werden er 93 retour ontvangen: 47 van verpleeghuisartsen, verbonden aan de geselecteerde nietintensief samenwerkende verpleeghuizen (groep A) en 47 van verpleeghuisartsen verbonden aan de intensief samenwerkende verpleeghuizen (groep B). De totale respons bedroeg hiermee $68,6 \%$. Op basis van de beschikbare gegevens leverde de non-responsanalyse geen significante verschillen op tussen de groep responders en non-responders, voor wat betreft het geslacht, het aantal bedden en dagbehandelingsplaarsen van het verpleeghuis en de urbanisatiegraad.

\section{Aangegeven contactfrequentie en oordeel over de samenwerking:}

Ook is in relatie tot de verpleeghuisartsen-enquête nagegaan in hoeverre de oorspronkelijke verdeling in niet-intensief én intensief met huisartsen samenwerkende verpleeghuizen paste binnen de door de verpleeghuisartsen zelf aangegeven contactfrequentie met huisartsen.

Verplecghuisartsen van de verplecghuizen die als niet-intensief met huisartsen samenwerkend geselecteerd waren (groep A), bleken significant minder vaak werkcontactẹn met de huisartsen in hun verzorgingsgebied te hebben dan verplecghuisartsen uit de tegenovergestelde groep, te weten groep B. Van groep A had $7,9 \%$ van de artsen vaak contact met de huisartsen, $60,4 \%$ af en toe contact en $31,7 \%$ zelden of nooit. Deze percentages verschilden duidelijk van die van groep $B$, waarin ze respectievelijk op $43,9 \%, 42,2 \%$ en $13,9 \%$ lagen $\left(X^{2} ; \mathrm{p}=0,000\right)$. 
Hoe verpleeghuisartsen van beide groepen de samenwerking met huisartsen beoordelen, in het algemeen en in relatie tot de verschillende verpleeghuisfuncties, wordt duidelijk uit tabel 5 . Ruim $70 \%$ van de verpleeghuisartsen uit groep A beoordeelde de contacten met huisartsen, zowel in het algemeen als in relatie tot in het verpleeghuis opgenomen patiënten, als redelijk tot goed. Bij de artsen uit groep B lag dit cumulatieve tevredenheidspercentage in beide gevallen hoger, namelijk rond de $90 \%$, hergeen overigens niet betekent dat dit verschil statistisch significant is. Datzelfde geldt voor de beoordeling van de contacten over substitutiepatiēnten. Respectievelijk 73,1\% (gr. A) en $80,3 \%$ (gr. B) was hierover redelijk tot goed tevreden.

De aanwezige tendens tot verschil in beoordeling leidt wel tot significante verschillen in relatie tot de beoordeling van de contacten over dagbehandelingspatiënten en met betrekking tot consultatieve contacten. Van de artsen uit groep B was $95,4 \%$ redelijk tot goed tevreden over de werkcontacten in relatie tot dagbehandelingspatiènten; voor groep $\mathrm{A}$ lag dit percentage op 54,3\% ( $\mathrm{X}^{2} ; \mathrm{p}=$ $0,010)$. Wat de beoordeling van consultatieve contacten betreft, waren deze percentages voor de gecumuleerde beoordeling "redelijk tot goed" als volgt: groep A: $70,6 \%$ en groep $B: 98,1 \%\left(X^{2} ; p=0,011\right)$. Minder goede samenwerking komt, zoals uit de tabel blijkt, ook hier vaker tot uiting bij de transmurale functies.

\section{Continuiteit van medische zorg:}

Tabel $6 \mathrm{a}, 6 \mathrm{~b}$ en $6 \mathrm{c}$ geven nadere informatie omtrent de mate van persoonlijk contact (al dan niet telefonisch) tussen verpleeghuisarts en huisarts, bij opname, tijdens opname en bij ontslag van patiënten in relatie tot de belangrijkste drie verpleeghuisfuncties. Verpleeghuisartsen uit groep A hadden bij opname ten aanzien van alle drie verpleeghuisfuncties procentueel minder vaak overdrachtscontact met de huisartsen dan die uit groep B. Het betrof hier echter geen significante verschillen. Gezien de responsaantallen mogen deze procentuele verschillen overigens wel als betekenisvol aangemerkt worden.

Ook al liggen de "nooit"-percentages van groep B lager dan die van groep A, uit de tabel wordt duidelijk dat een substantieel deel van de verpleeghuisartsen uit beide groepen nooit overdrachtscontacten met huisartsen heeft, bij opname van patiënten. Alle verpleeghuisartsen uit groep A en groep B geven aan dat ze in meer dan de helft van de klinische opnames de standaardprocedure volgen om bij de huisarts de medische gegevens van de betrokken patiënten op te vragen. Voor opnames op de dagbehandeling is dit in Groep A in $87,4 \%$ het geval en in groep $\mathrm{B}$ in $93,9 \%$ (ns; niet significant). Bij opnames van patiënten in substitutieprojecten vragen verpleeghuisartsen uit groep A in $43,0 \%$ en in groep B in $77,9 \%$ de gegevens ter inzage ( $\mathrm{p}=0,020)$.

Tabel $6 \mathrm{~b}$ geeft inzicht in de mate van persoonlijk contact tussen verpleeghuisarts en huisarts ten behoeve van patiënten die reeds opgenomen zijn in het verpleeghuis, op de verpleeghuisdagbehandeling en in substitutieprojecten. Gezien de responsaantallen worden geen significante verschillen gevonden ten aanzien van de transmurale verpleeghuisfuncties (dagbehandeling en substitutie). Toch zijn de procentuele verschillen tussen groep A en B in dit verband betekenisvol. De percentages bij groep B wijzen op een meer frequent zorgafstemmingscontact gedurende opname van patiënten in de betreffende verpleeghuisfuncties.

Ook ten aanzien van de persoonlijke overdrachtscontacten bij ontslag uit het 
verpleeghuis, uit de dagbehandeling en uit de substitutiezorg tenderen verpleeghuisartsen uit groep B naar een frequenter contact. De gevonden percentages spreken hier voor zich en zijn gezien de responsaantallen opnieuw betekenisvol (tabel 6c). Alle verpleeghuisartsen uit groep A en B gaven aan in ieder geval steeds ontslagbrieven te schrijven.

\section{Achtergrondkenmerken:}

Beide groepen verpleeghuisartsen werden vergeleken op achtergrondkenmerken. De gemiddelde leeftijd van de verpleeghuisartsen in groep A was 42,6 jaar (sd 6.9) en in groep B eveneens 42,6 jaar (sd 7,7). De geslachtsverdeling man/vrouw was in beide groepen ongeveer 1:1. Het gemiddeld aantal uren per week dat men werkt, bedrocg in groep A 29,7 (sd 7,0) en in groep B 30,4 (sd 6,5). Het gemiddeld aantal jaren dat men in het huidige verpleeghuis werkzaam was, bedroeg voor de verpleeghuisartsen uit groep A 6,3 jaar (sd 5,5) en voor de verpleeghuisartsen uit groep B 8,5 jaar (sd 7,8). Deze cijfers waren niet significant verschillend. Er waren eveneens geen significante verschillen aantoonbaar, tussen de artsen van beide groepen, in het gemiddeld aantal klinische verpleeghuispatiënten per verpleeghuisarts en de gemiddelde aantallen dagbehandelingspatiënten en substitutiepatiënten per verpleeghuisarts. Van de verpleeghuisartsen uit groep $\mathrm{A}$ had $58,7 \%$ na de medische opleiding wel eens een tijdje in een huisarts-praktijk gewerkt; ten aanzien van groep B lag dit percentage op $75,0 \%$.

Wat de ervaren kosten/batenbalans, gerelateerd aan de medische zorg voor 120 ouderen, betreft gaf ongeveer een kwart van de artsen uit beide groepen aan tenminste eens per maand het gevoel te hebben dat men zich teveel uitslooft voor de eigen patiënten, gemeten naar wat het aan waardering oplevert (groep A: 23,9\%; groep B: $25,4 \%$ ); bij $50,5 \%$ van de artsen uit groep A, respectievelijk $24,6 \%$ van de artsen uit groep B was dit een paar keer per jaar her geval.

Daarmee bestaat er ten aanzien van dit item een significant verschil tussen de verpleeghuisartsen uit beide groepen $(\mathrm{p}=0,023)$.

Wat de achtergrondkenmerken betreft, resteren nog de eventueel ervaren leemtes in kennis. 59,6\% van de verpleeghuisartsen uit groep $A$ en $47,9 \%$ van de artsen uit groep B gaf aan wel eens hiaten in geriatrische kennis te ervaren. Dit is geen statistisch significant verschil. Van de artsen uit groep A en groep B had 39,6\% respectievelijk $17,1 \%$ behoefte aan meer kennis over de mogelijkheden van andere zorgaanbieders; dit betreft wel een significant verschil $\left(X^{2} ; p=0,028\right)$.

Een ander significant verschil is er ten aanzien van het ervaren gebrek aan kennis over de zorgwetgeving. $81,3 \%$ van de artsen uit groep A versus $53,6 \%$ van de artsen uit groep $B$ gaf hieraangaande hiaten in de kennis aan. $\left(X^{2} ; p=0,008\right)$.

Ruim een kwart van de artsen uit groep A $(28,8 \%)$ en eenvijfde van de artsen uit groep B $(18,3 \%)$ ervoer tenslotte een gebrek an kennis over indicatie- en zorgtoewijzingsprocedures (ns;niet significant).

\section{Samenwerkingsottitude:}

De visie van de verpleeghuisartsen uit beide groepen A en B op de samenwerking met huisartsen werd getoetst aan de hand van een aantal stellingen (tabel 7). Als we de percentages van de artsen uit beide groepen beschouwen, valt op dat alle stellingen, inclusief de sterk domeingerichte stellingen over de medische zorg in 
verzorgingshuizen (=stelling $\mathrm{f}$ en $\mathrm{g}$ ) in grote lijnen adhesie krijgen van de artsen uit beide groepen. Er waren daarbij geen statistisch significante verschillen aanwezig.

Toch zijn er procentueel enige verschillen in de visie van beide groepen, die wellicht betekenisvol zijn. Verpleeghuisartsen uit groep B leken het verplecghuis wat vaker als expertisecentrum voor ouderenzorg te beschouwen en ze achtten eveneens de deskundigheid van de verpleeghuisarts meer onmisbaar voor de huisarts. Ze onderschreven ook in een hoger percentage de stelling dat hagro's gebruik moeten maken van een verplecghuisarts als consulent. Daarbij waren verpleeghuisartsen uit groep B er wat minder vaak van overtuigd dat, in relatie tot de bevordering van de onderlinge samenwerking met huisartsen, gezamenlijke standaardontwikkeling en gezamenlijke bij- en nascholing noodzakelijk zijn. Deze groep verpleeghuisartsen leek ook wat minder overtuigd te zijn van de noodzaak tot overname van de medische zorg in verzorgingshuizen door verpleeghuisartsen. Tenslotte zagen ze de huidige structuur en regelgeving van de gezondheidszorg ook minder vaak als sta in de weg voor de samenwerking tussen huisarts en verpleeghuisarts.

Wat de inschatting van het belang van de samenwerking met andere hulpverleners in de ouderenzorg betreft, vond $97,4 \%$ van de verpleeghuisartsen uit groep A en 97,0\% uit groep B de samenwerking met de huisarts belangrijk. Voor andere disciplines waren de percentages op de score "belangrijk" voor groep A en B achtereenvolgens: wijkverpleegkundige: $72,9 \%$ en $82,3 \%$; fysiotherapeut (eerstelijn): $50,5 \%$ en $34,8 \%$; maatschappelijk werkende (eerstelijn) $24,8 \%$ en $38,5 \%$; gezinsverzorgende: $39,3 \%$ en $44,1 \%$; apotheker (eerstelijn): 15,7\% en $32,1 \%$; medisch specialist: 76,1\% en 76,5 \%; medewerker RIAGG: 74,6 en $86,8 \%$. Significante verschillen tussen beide groepen werden in dit verband niet aangetoond.

\section{Samenwerkingsknelpunten:}

Ook aan de verpleeghuisartsen werd tenslotte gevraagd in hoeverre bepaalde knelpunten in relatie tot de samenwerking met de huisartsen een belangrijke roll spelen (tabel 8). In beide groepen vond meer dan de helft van de artsen de telefonische bereikbaarheid van de huisartsen een probleem; in groep A was dit overigens wat meer het geval dan in groep B. Verpleeghuisartsen uit groep B beschouwden de wachtlijstproblematiek wat vaker als belangrijk knelpunt. Artsen uit groep A vonden in 55,3\% dat de tijd die samenwerking kost een belangrijk probleem is; voor artsen uit groep B was dit maar in $25,6 \%$ het geval, waarmee beide groepen ten aanzien van dit item significant verschillen. Voor $58,7 \%$ van de artsen uit groep A en $44,2 \%$ van de artsen uit groep B was de onbekendheid van de huisarts met het werk van de verpleeghuisarts ook een belangrijk probleem. Het ontbreken van een financiële prikkel voor de samenwerking werd door verpleeghuisartsen uit groep B minder frequent als belangrijk knelpunt gezien. De andere knelpunten speelden ook een rol, doch voor beide groepen gold dit voor minder dan de helft van de gevallen. 


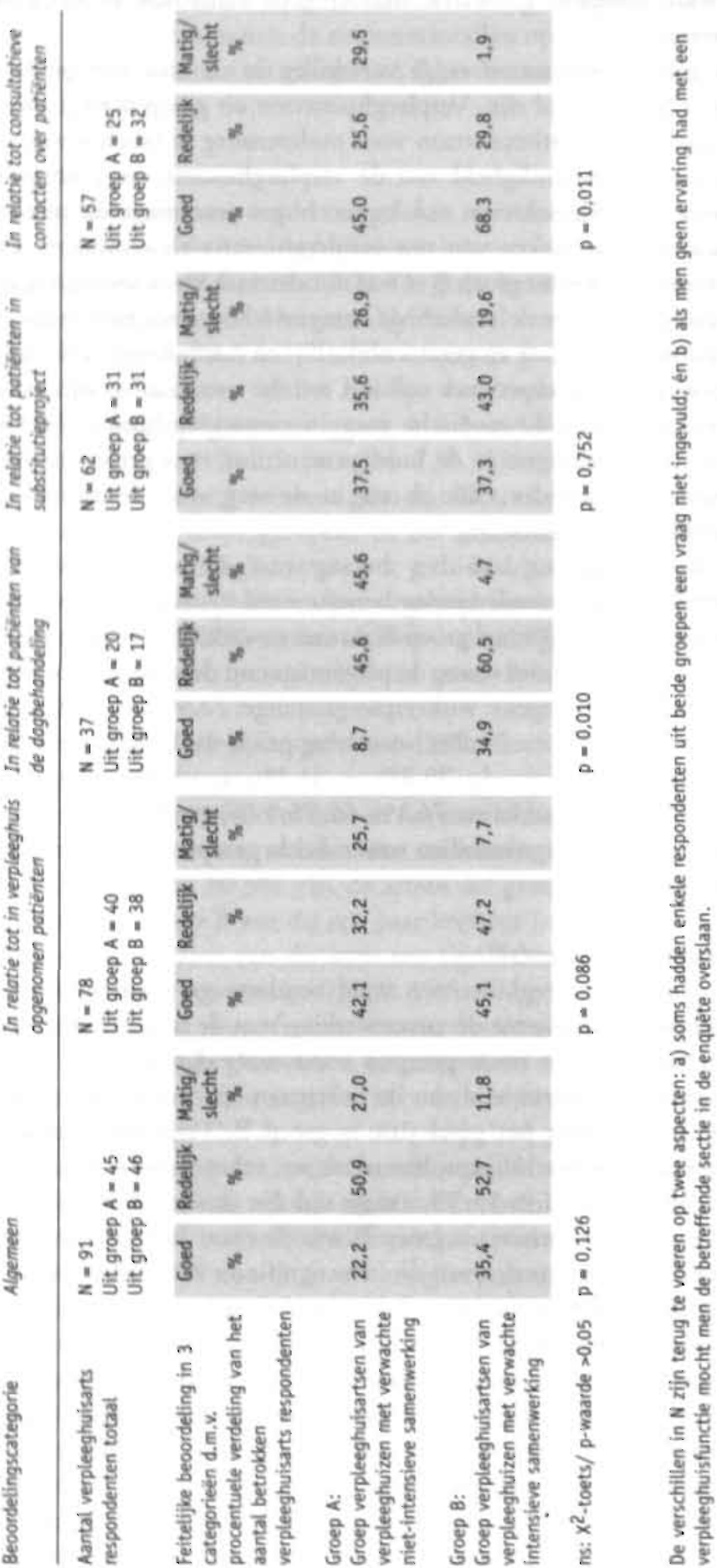

TABEL 5:

Beoordeling van de samenwerking met. huisartsen, in algemene zin en in relatie tot de verschillende verpleeghuisfuncties, door $\mathbf{2}$ groepen verpleeghuisartsen, respectievelijk een groep verpleeghuisartsen uit verpleeghuizen waarvan verwacht mocht worden dat ze niet intensief met huisartsen samenwerkes (verpleeghuisartsengroep A) en een groep verpleeghuisartsen uit verpleeghuizen waarvan wel intensieve samenwerking met huisartsen verwacht. mocht worden (verpleeghuisartsengroep B). 


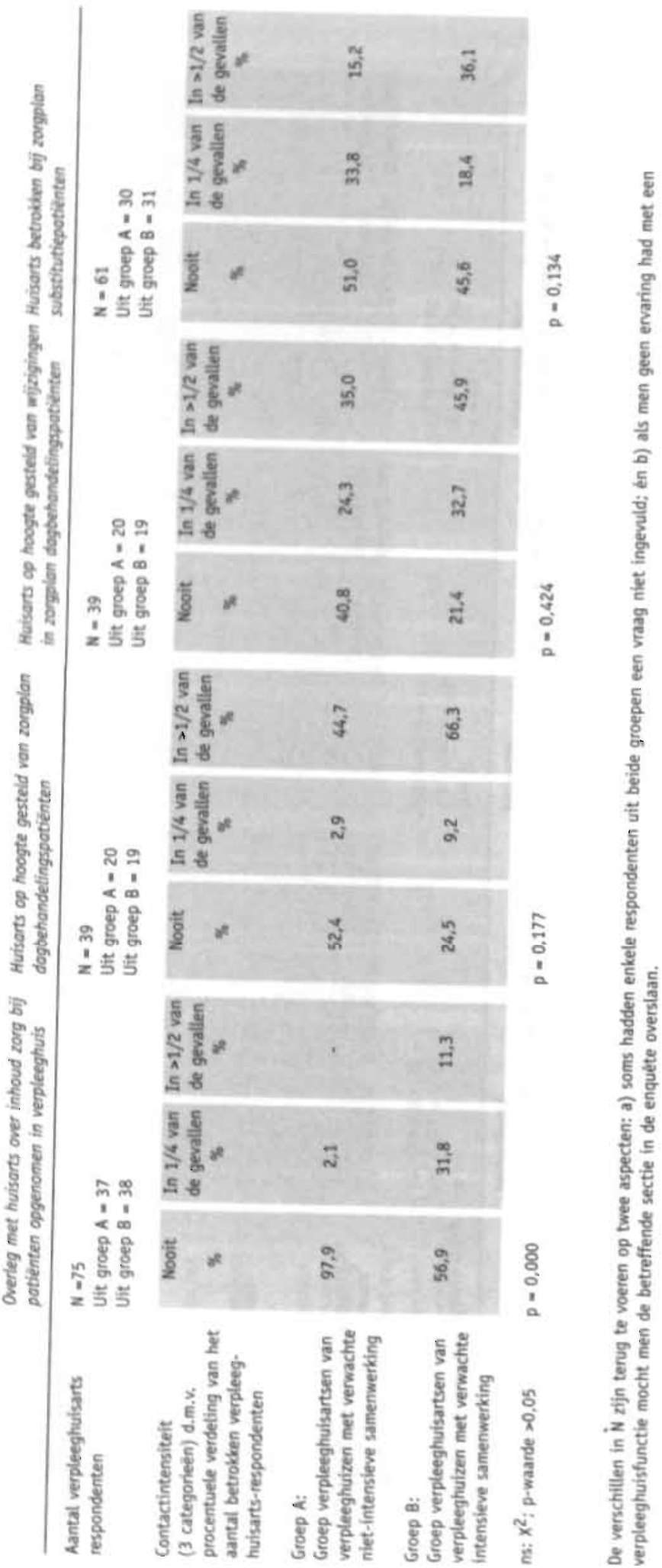

TABEL $6 B$ :

De mate waarin persoonlijk (al dan niet telefonisch) contact bestaat met de huisarts tijdens opname van een patiènt in het verpleeghuis, op de dagbehandeling of in een substitutieproject, zoals aangegeven door respectievelijk de groep van verpleeghuisartsen afkomstig van verpleeghuizen waarvan verwacht mocht worden dat ze niet-intensief met huisartsen samenwerken (verpleeghuisartsengroep A) en de groep verpleeghuisartsen die afkomstig is van intensief met huisartsen samenwerkende verpleeghuizen (verpleeghuisartsengroep B). 
TABEL $6 C$ :

De mate waarin pessoontijk (at dan niet telefonisch) contact bestaat met de huisarts bij ontslag van een patient wit het verpleeghuis, uit de dagbehandeling of uit een substitutieproject. zoals aangegeven door iespectievelijk de groep van verpleeghuisartsen aftomstig van

verpleeghuizen waarvan verwacht mocht worden dat ze niet-intensief met huisartsen samenwerken (verpleeghuisartsengroep $\boldsymbol{A}$ ) en de groep verpleeghuisartsen die afkomstig is van intensief met huisartsen samenwerkende verpleeghuizen (verpleeghuisartsen. groep B).

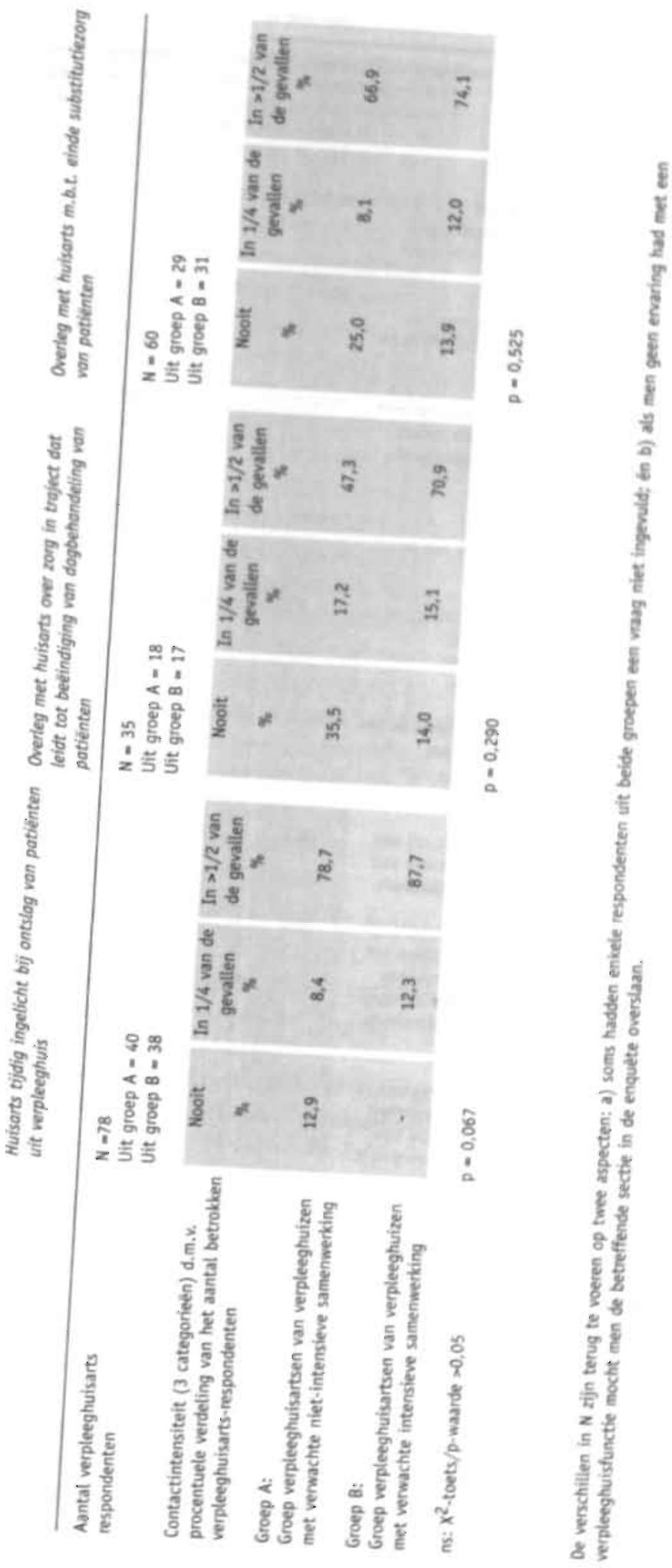


$\begin{array}{ccl}\text { Mee eens tot } & \text { Deels mee oneens } & \text { p- } \\ \text { zeer mee eens } & \text { tot zeer mee oneens. } & \text { waarde }\end{array}$ TABEL 7 :

Bent u het eens met de volgende stellingen?

a. Een patient die definitief in het verpleeghuis opgenomen is, beschouw ik niet meer als een patient van de huisarts

b. Bij de behandeling van revalidatiepatienten in het verpleeghuis hoort de huisarts nadrukkelijk betrokken te zijn

c. De huisarts kan het beste zelf bepaien. wanneer hij het tijd acht om een traject van consultatie door de verpleeghuisarts in te retten

d. Ik zie het verpleeghuis als een expertisecentrum op het gebied van de ouderenzorg

e. De ontwikkelingen in de ouderenzorg maken de deskundigheid van de verpleeghuisarts voor de huisarts onmisbaar

f. De medische zorg in verzorgingshuizen kan m. I., met het oog op de groeiender zorgvraag aldaar, beter overgenomen worden door de verpleeghuisarts

9. De verpleeghuisarts zou volgens mij een rol kunnen spelen bij het regisseren van de zorgverlening in het verzorgingshuis

h. Het verdient aanbeveling dat hagro's (huisartsengroepen), met betrekking tot het optimaliseren van de te verrichten taken op het gebied van de ouderenzorg. gebruik maken van een verpleeghuisarts als consulent.

1. De samenwerking tussen huisarts en verpleeghuisarts kan worden bevorderd doot het gezamentijk ontwikkelen van standaarden voor de medische zorg voor ouderen

j. De samenwerking tussen huisarts en verpleeghuisarts kan worden bevorderd door het geven van aandacht aan de wederzijdse beroepsinhoud in de basis- en vervolgopleidingen

k. De samenwerking tussen huisarts en verpleeghuisarts $k$ an worden bevorderd door het samen ontwikkelen en volgen van bij- en nascholing

L. De huidige wet- en regelgeving, de tariefen honoreringsstructuur en de werkwijze van de indicatiecommissies e.d., staan de samenwerking tussen de huisarts en de verpleeghuisarts in de weg
De visie met betrekking tot de samenwerking met de huisarts in de zorg voor ouderen,

door een groep verpleeghuisartsen van verpleeghuizen waarvar verwacht mocht worden dat ze niet-intensief met huisartsen samenwerken (verpleeghuisartsengroep A) en een groep verpleeghuisartsen van verpleeghuizen waarvan wel een intensieve samenwerking met huisartsen verwacht mocht worden (verpleeghuisartsen. groep. B)

(ns: $X^{2} ; \mathrm{p}$-waarde $>0,05$ )

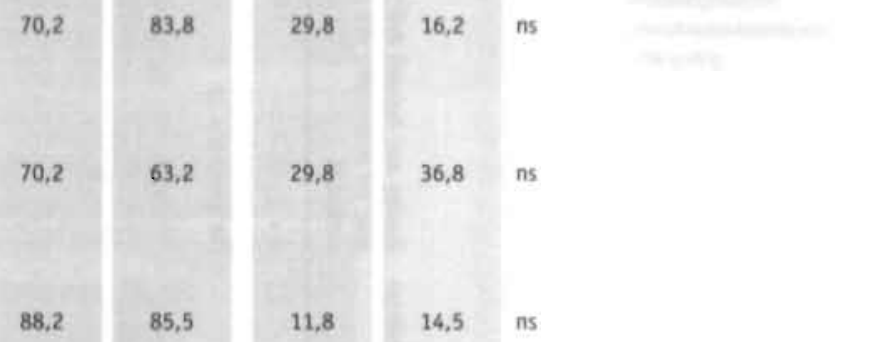


TABEL 8;

De mate waarin twee groepen

verpleeghuisartsen, respectievelijk cen groep afkomstig van cerpleeghuizen waarvan geen intensieve samenwerking met huisartsen verwacht mocht worden (verpleeghuisartsengroep A) en een groep afkomstig van verpleeghuizen waarvan wel een intensieve samenwerking met huisartsen verwacht mocht worden (verpleeghuisartsengroep 8 ). bepaalde knelpunten belangrijk vinden in relatie tot de ondertinge

samenwerking met huisartsen.

(n: $X^{2} ; p$-wasde $>0,05$ )

\begin{tabular}{|c|c|c|c|c|c|}
\hline $\begin{array}{l}\text { Een knefpunt in de samenwerking kan } \\
\text { zijn: }\end{array}$ & $\begin{array}{l}\text { Verpleeg- } \\
\text { huisartsen- } \\
\begin{array}{c}\text { groep A } \\
\mathrm{N}=45 \\
\mathrm{*}\end{array}\end{array}$ & $\begin{array}{c}\text { Verpleeg- } \\
\text { huisartsen- } \\
\begin{array}{c}9 r o e p ~ \\
N=46 \\
\text { N }\end{array}\end{array}$ & $\begin{array}{c}\text { Verpleeg- } \\
\text { huisartsen- } \\
\text { groep A } \\
\begin{array}{c}\mathrm{N}=45 \\
\text { W }\end{array}\end{array}$ & $\begin{array}{c}\text { Verpleeg- } \\
\text { huisartsen- } \\
\text { groep } 8 \\
N=46 \\
8\end{array}$ & \\
\hline $\begin{array}{l}\text { Het niet persoonlijk kennen van de } \\
\text { huisarts(en) }\end{array}$ & 41,2 & 37,3 & 58,8 & 62,7 & $\mathrm{~ns}^{*}$ \\
\hline $\begin{array}{l}\text { De telefonische bereikbaarheid van de } \\
\text { huisarts(en) }\end{array}$ & 64,5 & 53,8 & 35,5 & 46.2 & ns \\
\hline $\begin{array}{l}\text { De wachtlijstproblematiek van het } \\
\text { verpleeghuis }\end{array}$ & 35,1 & 45,7 & 64.9 & 54,3 & is \\
\hline De tijd die samenwerking lost. & 55,3 & 25,6 & 44,7 & 74,4 & 0,007 \\
\hline $\begin{array}{l}\text { Het ontbreken van een extra vergoeding } \\
\text { voor de samenwerking ( }=\text { financiele } \\
\text { prikkel) }\end{array}$ & 29.8 & 12,8 & 70.2 & 87,2 & ns \\
\hline $\begin{array}{l}\text { De onbekendheid met het werk van de } \\
\text { huisarts }\end{array}$ & 1.8 & 8,2 & 98,2 & 91,8 & ns \\
\hline $\begin{array}{l}\text { De onbekendheid van de huisarts met het } \\
\text { werk van de } \\
\text { verpleeghuisarts }\end{array}$ & 58,7 & 44,2 & 41,3 & 55,8 & ns \\
\hline $\begin{array}{l}\text { Het ontbreken van richtijinen voor de } \\
\text { samenwerking }\end{array}$ & 31,1 & 33,0 & 68,9 & 67,0 & ns \\
\hline De expansiedrift van het verpleeghuis & 16,5 & 19.7 & 83.5 & 80.3 & ns \\
\hline
\end{tabular}

Ninder belangrik

tot geen knelouet

p ourde

\section{BESCHOUWING}

In dit onderzoek is door middel van een bij huisartsen en verpleeghuisartsen afgenomen enquête getracht nadere informatie te krijgen over hun onderlinge samenwerking en over de factoren die daarbij mogelijk een bepalende rol spelen. Met het oog op het belang voor de patiënt ging daarbij speciale belangstelling uit naar de continuïteit van medische zorg.

Ten aanzien van de onderzoeksmethode werd voortgeborduurd op eerder door ons verricht onderzoek. ${ }^{*}$ De selectie van verpleeghuisartsen en huisartsen vond dientengevolge plaats vanuit én rondom verpleeghuizen waarvan géén, respectievelijk wél nauwe samenwerking met huisartsen verwacht mocht worden. De belangrijkste verschilfactor bleek daarbij overigens de urbanisatiegraad te zijn, die derhalve bij de definitieve selectie voor dit onderzoek geneutraliseerd werd.

Deze selectie maakte bovendien onderlinge groepenvergelijking van huisartsen en verpleeghuisartsen mogelijk.

Aan de analyse van de verkregen onderzoeksdata lag schema 1 ten grondslag. Uit de resultaten blijkt dat zowel verpleeghuisartsen van, als huisartsen rondom verpleeghuizen, waarvan een intensieve samenwerking met huisartsen verwacht mocht worden, inderdaad aangeven significant vaker werkcontacten te hebben. Ook de beoordeling van de onderlinge samenwerking blijkt bij hen beter te zijn, hergeen als een logisch uitvloeisel gezien mag worden. Deze bevindingen ondersteunen daarmee de uitkomsten van het eerdere onderzock." 
Refererend aan de eerste vraagstelling van dit onderzoek blijken huisartsen en verpleeghuisartsen rondom verpleeghuizen waarbij sprake is van een meer intensieve samenwerking, aan te geven dat daar, in relatie tot de verschillende verpleeghuisfuncties, bovendien sprake is van een meer frequent overdrachtscontact en zorgafstemmingscontact over patiënten. Een grotere contactintensiteit en een als beter ervaren samenwerking kunnen dus in ieder geval tot een betere continuïteit van medische zorg leiden (zie ook schema 1).

Desondanks heeft nog steeds een aanzienlijk deel van de huisartsen en verpleeghuisartsen uit alle groepen nauwelijks tot geen werk- en overdrachtscontacten; een weliswaar bekend gegeven dat echter zeker als pregnant bestempeld mag worden. In relatie tot patiënten die definitief in het verpleeghuis opgenomen worden, is dit wellicht nog begrijpelijk, aangezien er in die situatie sprake is van een totale behandelingsovername door de verpleeghuisarts. De behandelbetrokkenheid van de huisartsen eindigt dan in de meeste gevallen met het opsturen van de medische gegevens. Overigens krijgen huisartsen ook geen financiële vergoeding meer voor deze patiënten. Een en ander past ook bij de gegeven antwoorden op de eerste stelling in tabel 3 respectievelijk tabel 7.

Minder begrijpelijk is dit gebrek aan contact in relatic tot kortdurend ter revalidatie in het verpleeghuis opgenomen patiènten en zeker ook in relatie tot dagbehandelingspatiënten en substitutiepatiënten, waarbij in de praktijk toch sprake is van een situatie waarin huisartsen én verpleeghuisartsen zich allebei medisch met de patiënt bemoeien.

128 Winsten ten aanzien van de onderlinge samenwerking tussen huisarts en verpleeghuisarts moeten, juist ten behoeve van patiënten als deze, geboekt kunnen worden. ${ }^{\text {wo. }}$

De tweede vraagstelling betrof de factoren die mogelijk een bepalende rol zouden kunnen spelen bij eventueel gesignaleerde verschillen met betrekking tot de continuilteit van medische zorg.

Nemen we de achtergrondkenmerken van de huisartsen en verpleeghuisartsen in acht (schema 1) dan blijken er geen significante verschillen te bestaan in persoonsen praktijkkenmerken tussen de beide groepen huisartsen en tussen de beide groepen verpleeghuisartsen. Datzelfde geldt voor de kwantitatieve betrokkenheid bij de doelgroep van oudere patiënten.

Ongeveer de helft van de huisartsen uit beide groepen I en II en een kwart van de verpleeghuisartsen uit beide.groepen A en B geven ten aanzien van de arbeidssatisfactie, gerelateerd aan de doelgroep van hun oudere patiënten, aan, dat ze minstens eenmaal per maand het idee hebben meer tijd aan de zorg voor deze doelgroepen te besteden, dan dat ze er in de vorm van waardering voor terugkrijgen. Deels blijkt dit te maken te hebben met een gebrek aan waardering. Ook al komen hier geen opvallend significante verschillen uit, dan dient dit gegeven toch als een belangrijk signaal beschouwd te worden.

Wat de kennisaspecten aangaande de ouderenzorg betreft, blijken verpleeghuisartsen uit beide groepen A en B opvallend genoeg vaker inhoudelijke manco's aan te geven inzake de geriatrie (resp. 59,6\% en 47,9\%) dan respondenten uit beide huisartsengroepen I en II ( $\mathrm{nl} .26,0 \%$ en 33,9\%). Wat, naast eventuele onterechte bescheidenheid, hiervan de betekenis is, is niet duidelijk. Het feit dat verpleeg- 
huisartsen veel frequenter betrokken zijn bij ouderen met complexe zorgproblemen kan hier ook een rol spelen, omdat zij ondanks hun ervaring toch regelmatig kunnen merken dat er nog kennishiaten zijn met betrekking tor de probleemoplossing bij deze groep fors zorgbehoevende patiênten. Het zou hier dus een relatief fenomeen kunnen betreffen: naarmate je meer met een probleem te maken krijgt, merk je sneller dat je te weinig weet; of om met Socrates te spreken: "Ik weet nu dat ik eigenlijk weinig of niets weet!"

Kennisgebrek met betrekking tot de mogelijkheden van andere zorgaanbieders is er bij ongeveer de helft van de artsen uit beide huisartsengroepen en bij tweevijfde deel van de verpleeghuisartsen uit de niet-intensief met huisartsen samenwerkende verpleeghuizen, respectievelijk eenvijfde deel van de verplecghuisartsen uit de verpleeghuizen die nauwer met huisartsen samenwerken. Daarmee blijken deze laatsten hieraangaande significant minder leemtes aan te geven. Wellicht zijn ze daardoor beter toegerust voor samenwerkingsactiviteiten.

Deze laatste groep verpleeghuisartsen blijkt, in vergelijking tot hun collega's uit de andere groep, eveneens significant minder hiaten aan te geven ten aanzien van de kennis over de zorgwetgeving.

Van de huisartsen uit beide groepen geeft de helft aan kennisgebrek te hebben van de zorgwetgeving en veel meer dan de helft dat er eveneens te weinig kennis aanwerig is inzake zorgindicatieprocedures. Verpleeghuisartsen uit beide groepen geven met betrekking tot dit laatste relatief minder hiaten aan, hetgeen in feite ook een logische bevinding is, aangezien aan de opname van patiënten in de diverse verpleeghuisfuncties altijd een indicatic- en zorgtoewijzingsprocedure vooraf gaat.

Ook de samenwerkingsattitude was onderwerp van onderzoek bij alle groepen. Wat de visie van huisartsen en verpleeghuisartsen over het domein en de samenwerking in de zorgverlening betreft (schema 1), blijkt er in dit onderzoek bij alle groepen gemiddeld een grote overeenstemming te bestaan ten aanzien van een groot aantal stellingen hieraangaande. Dit geldt bijvoorbeeld voor het intramurale domein van de verpleeghuisarts, voor de noodzakelijke betrokkenheid van de huisarts bij de zorg voor tijdelijk in het verpleeghuis opgenomen patiënten en met betrekking tot het initiatief voor consultatie van de verpleeghuisarts.

Ook ten aanzien van de expertise van het verpleeghuis in het algemeen en de verpleeghuisarts in het bijzonder is er in feite een generale overeenstemming: alleen blijkt dat huisartsen die nauwer samenwerken met verpleeghuisartsen hier significant meer van overtuigd zijn. Waarschijnlijk omdat ze de concrete expertise beter en vaker kunnen ervaren.

Verpleeghuisartsen uit beide groepen zijn het in feite eens over het feit dat ze in de tockomst een meer pregnante rol moeten spelen in de medische zorg voor bewoners van verzorgingshuizen; de respondenten uit beide huisartsengroepen neigen er echter gemiddeld meer toe om het hiermee oneens te zijn. Deze bevindingen passen in dit verband prima in de nog niet afgeronde landelijke domeindiscussie hierover.

Dit onderzoek biedt echter onvoldoende aanknopingspunten om hier een duidelijke keuze te maken. Vast staat in ieder geval dat in de tockomst, in verzorgingshuizen, de groep bewoners, die behoefte heeft aan complexe, samengestelde zorg duidelijk zal toenemen. ${ }^{3}$ Daarnaast wordt de verzorgingshuiszorg evenals de 
verpleeghuiszorg als voorziening in de AWBZ opgenomen. Het zou dus denkbaar zijn dat de verpleeghuisarts de medische zorg voor juist die zwaar zorgbehoevende bewonersgroep gaat overnemen.

Daarnaast is het echter eveneens voorstelbaar dat huisartsen zelf, in hun actuele streven naar een betere samenwerking binnen de eigen beroepsgroep (i.e. ontwikkeling van HAGRO's: huisartsengroepen), hun care-gerichte werken gaan optimaliseren, danwel dat enkele huisartsen binnen een HAGRO zich meer specifiek in de zorgverlening ten behoeve van verzorgingshuisbewoners gaan specialiseren. Een en ander zou bovendien kunnen gebeuren door op adequate wijze consultatief gebruik te maken van de verpleeghuisarts, hetgeen zou aansluiten bij de door Meyboom-de Jong geprofileerde werkwijze voor de begeleiding van oudere patiënten in de huisartspraktijk."

Tenslotte zou in verzorgingshuizen ook een scenario van "gedeelde medische zorg" gehanteerd kunnen worden. Uit dit onderzoek en her eerder door ons verrichte onderzoek zijn immers aanknopingspunten te destilleren dat een goede onderlinge samenwerking tussen huisarts en verpleeghuisarts, ook in verzorgingsbuizen, tot een optimale medische zorg kan leiden." We zagen immers dat de samenwerkingsintensiteit tussen huisarts en verpleeghuisarts in transmurale projecten van verpleeghuizen, die veelal ten behoeve van extra zorgbehoevende verzorgingshuisbewoners plaatsvinden, positief beïnvloed wordt door goede samenwerkingsafspraken en gezamenlijke betrokkenheid bij de zorg en dat deze hogere samenwerkingsintensiteit in ieder geval leidt tot een betere continuüteit van medische zorg.

130 Welk model van medische zorg uiteindelijk gekozen zal worden in de verzorgingshuizen "nieuwe stiji", zal de tijd leren. Uiteindelijk gaat het om het realiseren van zorg op maat voor de betrokken patiënten. Verder en met name patiëntgebonden onderzoek zou hier uitsluitsel kunnen bieden.

Huisartsen en verpleeghuisartsen zijn er in ieder geval in algemene zin van overtuigd dat de samenwerking tussen beiden verbeterd kan worden door het gezamenlijk ontwikkelen van standaarden voor de medische zorg voor ouderen, door het gezamenlijk volgen van bij- en nascholing en door reeds in de basis- en beroepsopleidingen aandacht te besteden aan de beroepsinhoud van beide medische disciplines. In dit verband verdient het recente Nijmeegse initiatief voor gezamenlijke terugkomdagen voor huisartsen - én verpleeghuisartsen in opleiding dan ook steun."

Algemene adhesie bestaat er voor de stelling dat er enige wijzigingen ten aanzien van de organisatie en financiering van de medische zorg nodig zijn om de samenwerking te faciliteren. Dit sluit ook aan bij bevindingen uit eerder onderzoek. ${ }^{406}$

Her grootste deel van de huisartsen $(70,1 \%)$ die nauwer met verpleeghuisartsen samenwerken, hecht in ieder geval duidelijk aan het belang van deze samenwerking, waarmee de wederzijdse relatie russen samenwerking en visie op samenwerking bevestigd wordt (schema 1). Dit is significant meer dan in de andere groep huisartsen, waarvan overigens de helft toch ook van het belang van deze samenwerking overtuigd is. Verpleeghuisartsen blijken allemaal doordrongen van het belang van de samenwerking met de huisarts.

De meeste huisartsen en verpleeghuisartsen zijn verder overtuigd van het belang 
van samenwerking met andere disciplines in de ouderenzorg, waarbij nog opvalt dat huisartsen die minder intensief met verplecghuisartsen samenwerken wel significant meer belang hechten aan de samenwerking met de RIAGG. Ten aanzien van pariènten met psychogeriatrische problematiek, die weliswaar uiteindelijk vaak op het verpleeghuis aangewezen zijn, blijkt de RIAGG voor deze groep huisartsen vaak het eerste aanspreekpunt te zijn, hetgeen begrijpelijk is als we dit relateren aan de zojuist genoemde minder intensieve samenwerkingsrelatie met verpleeghuisartsen.

Kijken we tenslotte naar de eventuele knelpunten voor de onderlinge samenwerking (schema 1) dan mogen we constateren dat de in tabel 4 en 8 weergegeven knelpunten, die ook deels door de beroepsorganisaties aangevoerd worden, zeker een rol zullen spelen."

Huisartsen uit beide groepen hebben daarbij met name last van de wachtlijstproblematick en vinden dit het belangrijkste knelpunt; procentueel scoort dit knelpunt ook veel sterker dan bij de verpleeghuisartsen.

Huisartsen en verpleeghuisartsen die minder intensief met elkaar samenwerken vinden ook de aan samenwerking gekoppelde tijd procentueel vaker een belangrijk knelpunt dan huisartsen en verpleeghuisartsen die nauwer met elkaar samenwerken. Ook dit sluit aan bij eerder door ons verricht onderzoek.

Voor verpleeghuisartsen uit beide groepen is de telefonische bereikbaarheid van huisartsen een meer frequent gescoord belangrijk knelpunt, terwijl huisartsen van beide groepen niet zo'n groot probleem hebben met de bereikbaarheid van de verpleeghuisarts.

Voor een klein deel van de huisartsen en verpleeghuisartsen is ook het ontbreken van een financiële prikkel voor de samenwerking een belangrijk knelpunt, waarbij zowel huisartsen als verpleeghuisartsen die minder intensief samenwerken dit gemiddeld vaker aangeven.

Daarmee sluiten deze knelpunten aan bij gegevens uit de literatuur en bij resultaten van eerder verricht onderzoek. ${ }^{27-s}$

Verpleeghuisartsen hechten tenslotte meer frequent belang aan het feit dat huisartsen onvoldoende kennis van hun werkzaamheden hebben dan andersom de huisartsen doen; dit ondanks de eerder genoemde algemene overeenstemming met betrekking tot het reeds vroeg in de opleidingen aandacht schenken aan de wederzijdse beroepsinhoud én met betrekking tot het belang van gezamenlijke bijscholing en standaardontwikkeling.

Samenvattend blijkt er een betere continuïteit van medische zorg gerealiseerd te worden daar waar sprake is van een meer intensieve samenwerking tussen huisarts en verpleeghuisarts én waarbij deze samenwerking, op basis van duidelijke afspraken en goede wederzijdse ervaringen, ook meer naar tevredenheid verloopt. Daarbij zal deze betere continuïteit van medische zorg naar verwachting ten goede komen aan de betrokken pariënten.

Factoren die in dit verband, naast de urbanisatiegraad, zoals eerder gevonden, bevorderend kunnen werken, zijn:

- het belang dat zowel huisarts als verpleeghuisarts hechten aan een goede onderlinge samenwerking;

- een bij huisartsen aanwezige overtuiging dat het verpleeghuis in het algemeen 
en de verplecghuisarts in het bijzonder inhoudelijk iets toe te voegen hebben aan de zorg;

- voldoende kennis bij huisartsen over de mogelijkheden van de verpleeghuisarts en andersom;

- het feit dat beiden de tijd die samenwerkingsactiviteiten kosten niet teveel als knelpunt zien;

- een goede telefonische bereikbaarheid van de huisarts;

- het feit dat de wachtlijstproblematick voor huisartsen een stimulans zou kunnen zijn om ten behoeve van de betrokken pariënten nauwer met elkaar samen te werken, om zodoende acceptabele en draaglijke oplossingen te vinden voor de overbruggingsperiode tot opname,

Derhalve is het ons inziens belangrijk om nu en in de nabije toekomst de nadruk te blijven leggen op een goede onderlinge samenwerking tussen huisarts en verpleeghuisarts.

De eerder geschetste veranderingen in de ouderenzorg, waarbij de verpleeghuiszorg meer zal transmuraliseren en de huisartsgeneeskunde een partiële verschuiving van cure naar care zal doormaken, zijn hiervoor immers voldoende aanleiding. Bovendien leiden het groeiend aantal zorgbehoevende ouderen, die vaak en veel om hulp vragen en de ernst van de intramurale wachtlijstproblematiek, die door huisartsen daadwerkelijk wordt ervaren, nu al vaak tot een dermate hoge zorgvraag, dat het bijna ondoenlijk is hieraan te voldoen, ondanks de tijd en inspanning die men eraan besteedt. De bij een deel van zowel huisartsen als 132 verpleeghuisartsen aanwezige satisfactieproblematiek inzake hun zorg voor ouderen is in dit verband, zoals eerder aangegeven, een signaal dat aandacht verdient. Aspecten zoals deze vragen als het ware zelf om meer samenhang in de zorg, om meer verantwoorde transmurale zorg-alternatieven en om een betere onderlinge samenwerking tussen alle hulpverleners; dus ook tussen huisarts en verpleeghuisarts." Daarvoor zullen zeker knelpunten opgelost moeten worden. Kennisvergroting met betrekking tot elkaars werk, samen bijscholen, maar ook concreet overleggen én samenwerken in de zorg voor patiënten, daar waar dit geboden is, zijn hierbij essentiële ingrediënten. ${ }^{* 0}$

Samenwerking is niet dwingend op te leggen en vergt als het ware een groeimodel. Het wederzijdse consultatiemodel is daarvoor een goed uitgangspunt, dat zijn waarde reeds bewezen heeft en ook adhesie krijgt in dit onderzoek (stelling h. in tabel 3 en tabel 7). "Een grociscenario uitgaande van een consultatiemodel past ook prima in de meest recente nota van de NVVA en LHV inzake de samenwerking tussen huisarts en verpleeghuisarts," In die nota wordt namelijk uitgegaan van een flexibel complementair samenwerkingsmodel, waarbij de intensiteit van de samenwerking steeds kan worden aangepast aan de problemen van de doelgroep, aan de actualiteit en complexiteit van de zorgvraag, aan de situatie waarin de zorg verleend dient te worden en niet te vergeten aan het niveau tot waarop de onderlinge samenwerking zich reeds ontwikkeld heeft.

De beperkingen van dit onderzoek liggen voor een belangrijk deel bij de bereikte respons, die relatief laag was bij de huisartsen. De uiteindelijk gepresenteerde resultaten zijn misschien niet opzienbarend en mogelijk voor de hand liggend. 
Duidelijk is in ieder geval dat de samenwerking tussen verpleeghuisarts en huisarts nog een echte impuls nodig heeft. Een belangrijke voorwaarde in dit verband en ook goed passend in het verlengde van schema 1 is, dat er meer longitudinaal patiëntgebonden onderzock verricht wordt, om na te gaan of een betere samenwerking en continuîteit van zorg tussen huisarts en verpleeghuisarts inderdaad leiden tot een betere zorg voor de patiềnt. 


\section{LITERATUUR}

1. Dokter H. Onrwilckelingen in het aanbod. In: Dokter H, Lieshout P van, Schade B (red). Zorg aan huis, een stand van zaken. Urreche De Tijdstroom, 1996: 13-30.

2. Fontein P. Transmurale zorg een inleiding In: Crebolder HFJM e.a. (red). Handbock Thuiszorg (HAT). Utreche: De Tijdstroom, 1997; B 9.1-1/13.

3. Schols JMGA, Diederila JPM, Koopmans RTCM. Samenwerking russen huisarts en verpleeghuisarts. Twee actoren in een veranderende ouderenzorg. In: Crebolder HFJM e.a. (red). Handbock Thuiszorg (HAT). Ureche: De Tijdatroom, 1997 B 8.2-1/19.

4. Schols JMGA, Diederiks JPM, Koopmans RTCM. Samenwerking russen huisarts en verplecghuisarts: de parient moet er beter van worden. Tijdschr Verplecghuisgeneeskd 1997: 21 (themanr nov, 97): 10-4.

5. Schols JMGA. Wierik MJM te. Verpleqghuiszorg buiten de muren: dagbehandeling, consultatic en substituticprojecten. Ned Tijdschr Geneeskd 1993: 137(52): 2717-22.

6. PAOG curus: Samengestelde zorg voor ouderen: de huisurts en verplecghuisarts voondeundelen? Nijmegen:PAOG, 1997

7. Schols JMGA. Samenwerking huisarts en verpleeghuisarts. De verplecghuisarts kan adviscrend en ondersteunend optreden. Praktijkmanagement voor de huisars 1989; 7: 18-23.

8. Schols JMGA. Theunissen NIS, Bors V, Sinnema ME. Verplecghuiszorg in bewegingz een evaluatic van vijf substitutieprojecten verpleeghuiszorg. Tijdschr Gerontol Geriatr 1995; 26: 10-5.

9. Wersch-Spek MCM van de. De verplecghuisarts als medisch consulent in de eentelijnsgezondheidszorg. Medisch Contact 1987; 42: 1243-4.

10. Waltman RE, Tacoma WA. Sorry, I dont see nusing home patients. JABFP 1992; 5: 104-6.

11. Ouslander JG, Osterweil D. Physician's evaluation and management of nursing home residents. Ann Intern Med 1994: 121:584-92.

134 12. Williams ME. The physician's role in nursing home care: an overview. Geriarrics 1990: 45 (1):47-9.

13. Andrew RA. Analysis of a general practitioner's work in a private nursing home for the elderly. I R Coll Gen Pract. 1988: 38: 546-8.

14. Evans JM. Chutka DS, Fleming KC. Tangalos FG, Vittone J. Heathman RN. Medical care of nursing home residenes. Mayo Clirr Proc 1995: 70-694-702:

15. Franks P. Clancy CM. Nutting PA. Gatekecping revisited-protecting patients from overtrearment. N Engl ] Med 1992: 327(6): 424-9.

16. Basis-takenpakker van de huisars. Utreche LHV, 1982

17. Meyboom WA. Schaadt overdaad in de (huisarss)geneeskunde? The Practitioner 1991: 8:568.

18. Kersten TJJMT. De invloed van huisartsen in de rweedelijn. Proefichrift RU. Utrecht, 1991.

19. Casparie F. Gestructureerde samenwerking. Medisch Contact 1985; 40: 97-100.

20. Sips AJBI, Smeele 1. Voort JPM van der. De verwiisbrief naar de rweedelijn. NHG-standaard. Huisars Wer 1989: 32: 541-4.

21. Beugeling A. Wouden JC van der. De verwijpbrief in zijn contert. Medisch Contact 1989; 44: 873-6.

22. Kuster JAM, Beugen L. van. Jacobs JWM. Een experiment in communicatie. Medisch Contact 1987: 42: 112-4.

23. Pop R. Keijsers H.1M. Communicarie tussen huisarts en spocialist. Medisch Contact 1985; 40: 203-7.

24. Asamann PEMTh, Bouwens FGM, Timmermans JPA. Samenwerken gaat niet vanxelf. Wat men vindt en wat men wenst. Medisch Contact 1996; 51:637-8.

25. Pop P. Beusmans GHMI. Telefonische consultatie als diagnostisch bulpmidded. The Practitionet 1990; 635-8.

26. Plantenga HA. Her telefonisch consult als nascholingrvorm. Medisch Contact 1986; 41:47.

27. Carne S. A problem halved? I R Coll Gen Pract 1981: 32: 10.

28. Schuurman W, Everdingen JIE van, Schade E. De dermatoloog in de eernteliin. Huisars Wet 1992: 35(4): 161-3.

29. Vierhout WPM, Beusmans GHMT. Verwijnen GM. Ooī A van, HRM van Gasselt. Beck JHM van det. Gezamenlijk consult huisarts-specialist Medisch Contact 1987:42: 106-9. 
30. Ooij A van, Walenkamp GHIM, Geesink RGT, Arens HJ, Viethout WPM, Knottnerus JA. Consultatic in de huisartsprakrijk: een specialistische impressie. Medisch Contact 1992: 47: 118-20.

31. Have J ten, Buwalda J. Hoe het beter kan nussen huisars en specialist. Medisch Contact 1990: 45: 86-8.

32. Smit D] de. Consultatie tussen huisarts en specialist. Medisch Contact 1987: 42: 849-52.

33. Vierhout WPM. Knotrnerus JA, Ooij A van. Crebolder HFJM. Pop R, Wescling-Mrgens AMK, Beusmans GHMI. Effectiveness of joint consultarion sesions of general practitioners and orthopaedic surgeons for locomotor-system disorden. The Lancet 1995; 346: 990-4.

34. Meyboom-Jong de B. De oudere patiènt in becld. Huisars Wet 1991: 34(2): 82-8.

35. LHVINVVA. Handreiking voot de samenwerking huisarts-verplecghuierts. Rapportage van de getamenlijke werkgroep van de LHV en de NVVA. Utrecht, 1996.

36. Schols JMGA, Veer AJE de, Kerkstra A, Diederiks JPM, Koopmans RTCM, Sturmans F, Crebolder HFJM. Variatie in samenwerkingsintensiteit tusen verplecghuisars en huisars in Nederland. Geaccepterd voor publikatie in Tijduht Gezondheidsw.

37. Schols JMGA, Koopmans RTCM. Diederils JPM, Srurmans F, Crebolder HFJM. Contacten ussen verplecg: huisarts en huisares frequentic, aard en inhoud. TSG/Tijdachr Geandheidsw 1998; 76(6): 318-22.

38. Belcidsstuk over geramenlijke terugkomdagen voor VAIO's en HAIOK. VOVAVOHA, KU Nijmegen, 1999.

39. Post D. Veranderende patięnten in een veranderende omgeving. (Redactioned) Patient Care 1999: 26(5)) 8-10.

40. Werf G van der, Reenders K. Haalt de huisars 2020? Medisch Contact 1998; 53: 1126-8.

41. NVVA en LHV. Nota: Arts en ouderen: uitagende zorg. Een stap vooruit in de samenwerking rusen huisars en verplecghuisars. Uirecht: LHVINVVA, 1998. 


\section{BESCHOUWING EN SAMENVATTING}




\section{Из วИIWUOHว238 כИПTIVYИMA2}




\section{BESCHOUWING EN \\ AANBEVELINGEN}


De opbouw van dit proefschrift bestaat uit drie delen, te weten: "algemene inleiding" (deel 1), "vanuit institutionele zorgverlening naar extramurale zorgverlening" (deel 2) en "de samenwerking verpleeghuisarts en huisarts nader onderzocht" (deel 3). Daarnaast worden in een addendum enige voorbeelden gepresenteerd van klinisch onderzoek in of vanuit het verpleeghuis.

In de "algemene inleiding" (deel 1) wordt de hedendaagse verpleeghuiszorg nader gepositioneerd in het spectrum van de zorg voor ouderen en chronisch zieken. Demografische ontwikkelingen, capacitaire en budgettaire problemen in de gezondheidszorg, overheidsvisies en veranderende wensen van de zorgvragers blijken ertoe bijgedragen te hebben dat in het afgelopen decennium de verpleeghuisverplaatste zorg zich sterk ontwikkeld heeft.'

Deze ontwikkeling doet nieuwe zorgmodaliteiten ontstaan en dwingt tevens tot specifieke aandacht voor de samenwerking tussen zorgverleners binnen en buiten het verpleeghuis.

In de algemene inleiding wordt een drietal vraagstellingen geformuleerd in het kader van het verplecghuiszorg- én verplecghuisgeneeskundig onderzoek en in samenhang daarmee wordt de opbouw van het proefschrift aangegeven.

De vraagstellingen betroffen:

1. Welke doelgroepen maken intra-, semi- en extramuraal gebruik van verpleeghuiszorg?

2. Welke zijn de effecten van de verpleeghuiszorg op deze doelgroepen?

3. Hoe staat het met de (transmurale) samenwerking russen disciplines uit het verpleeghuis en disciplines daarbuiten?

Binnen het kader van vraagstelling 1 wordt een profiel beschreven van dagbehandelingspatiënten; ten aanzien van vraagstelling twee wordt verslag gedaan van een inventariserend onderzoek naar de effecten van een aantal substitutieprojecten verpleeghuiszorg en ten aanzien van vraagstelling 3 wordt uitvoerig ingegaan op de samenwerking tussen verplecghuisarts en huisarts.

In het hiernavolgende wordt in eerste instantie de volgorde van de onderscheiden delen van het proefschrift gevolgd. Ter afsluiting worden de onderzoeksactiviteiten aangaande de samenwerking tussen verpleeghuisarts en huisarts in een breder kader geplaatst.

\section{Vanuit institutionele zorgverlening naar extramurale zorgverlening}

Deel 2 waarin de transmurale ontwikkeling van de verplecghuiszorg aan de orde komt, is voor wat betreft de paragrafen $2.1,2.2$ en 2.3 beschrijvend van aard. $\mathrm{Na}$ een kort historisch perspectief, worden de mogelijkheden van de hedendaagse verplecghuiszorg beschreven.

Paragraaf 2.4 doet verslag van de eerste ervaringen met een aantal substituticprojecten verpleeghuiszorg in verzorgingshuizen, zoals die plaatsvinden vanuit verpleeghuis de Riethorst (voorheen St. Agnes) te Geertruidenberg. Het betreft een kleinschalig inventariserend onderzoek waarbij het verzamelen en verwerken van ervaringsgegevens centraal stond.

Het belang van effect-onderzoek is duidelijk. Evaluatic is immers onmisbaar bij zorgvernieuwing, want alleen daardoor is te beoordelen of continuering en brede 
verspreiding van de innovatie wenselijk is. Ideaal bij een zorgvernieuwingsexperiment zou de aanwezigheid van een controlegroep zijn, die uit vergelijkbare patiēnten met een traditioncle zorgverlening bestaat. Hierdoor kan immers beoordeeld worden of de innovatie verbetering van kwaliteit, zorg op maat en efficiëntie oplevert. ${ }^{2}$ Het is echter - afgezien van ethische problemen - niet eenvoudig om een zuivere controlegroep samen te stellen. De pluriformiteit van de doelgroẹp verpleeghuisgeinndiceerde patiènten en de bij veel patiënten aanwezige complexe problematick maken het immers niet gemakkelijk om via randomisatie homogene onderzoeksgroepen te maken. Bovendien is, door hun vulnerabiliteit, tijdens de looptijd van wetenschappelijk onderzoek een aanzienlijke uitval van patiènten te verwachten. Een mogelijke oplossing, die deels tegemoet kan komen aan deze problemen, is om vooralsnog het accent te leggen op longitudinaal onderzoek bij (populaties van) verpleeghuis(geïndiceerde)patiënten, die in het onderzoek controle voor zichzelf kunnen zijn. Uiteraard zal daarbij gezorgd moeten worden voor de afwezigheid van een "carry-over effect", zodat bij het meten van het effect van verschillende interventies niet een situatie ontstaat dat het effect van de ene interventie van invloed is op de effectiviteit van de erop volgende interventie.

Geconstateerd mag worden dat gedegen (landelijk) effectonderzoek met betrekking tot de extramurale verpleeghuiszorg ontbreekt. Ten aanzien van de verplecghuisdagbehandeling werd in paragraaf 2.3 al een vergelijkbare constatering gemaakt. Niettemin wordt uit het in paragraaf 2.4 weergegeven onderzoek duidelijk dat verpleeghuis-substitutiezorg vooralsnog geen echte verpleeghuiszorg is en derhalve zeker voor kwaliteitsverbetering vatbaar. Bij het verrichten van dergelijk onderzoek is het overigens ook belangrijk om rekening te houden met het feit dat de optiek van de patiënt/bewoner veelal anders is dan die van de hulpverlener. Zo kan bij de substitutiezorg ontvangende bewoners en hun familieleden grote satisfactie bestaan, omdat voortzetting van het verblijf in het eigen appartement binnen het verzorgingshuis gerealiseerd wordt, terwijl bij, de verpleeghuismedewerkers die de substitutiezorg verlenen bedenkingen bestaan over de kwaliteit van de verpleeghuisvervangende zorg, omdat zij het idee hebben dat het volwaardige verpleeghuiszorgconcept in het project onvoldoende gerealiseerd wordt.

Paragraaf 2.5 kan beschouwd worden als een overgang naar het deel over de samenwerking tussen verpleeghuisarts en huisarts. Er wordt nader ingegaan op de kenmerken van de doelgroep voor de verpleeghuisdagbehandeling, waarmee ook bijgedragen wordt aan de primair gewenste beschrijving van de doelgroepen voor verplecghuiszorg.

Het beschrijven van de kenmerken van dagbehandelingspatiënten kan bovendien enig inzicht verschaffen in de kenmerken van transmurale patiënten, die zich bevinden in het traject tussen specifieke, institutionele verpleeghuiszorg en specifieke thuiszorg. Daarenboven zijn zowel huisarts als verpleeghuisarts betrokken bij de behandeling van dagbehandelingspatiënten.

Uit het onderzoek blijkt dat het merendeel van de dagbehandelingspatiènten ouder is dan 65 jaar en tweevijfde deel zelfs ouder dan 80 jaar. Er is een lichte oververtegenwoordiging van vrouwen en de patiënten komen grotendeels vanuit de eigen thuissituatie en blijken gekenmerkt te worden door een morbiditeitspatroon van chronische aandoeningen, die gepaard gaat met een aanzienlijke 
invaliditeit en beperkingen van de mobiliteit. De gemiddelde hulpbehoefte en behandelduur (driekwart jaar) blijken in de periode 1986-1995 ongeveer gelijk gebleven te zijn. Voor ruim 10 procent van de somatische en 40 procent van de psychogeriatrische patiënten blijkt de dagbehandeling een voorstation voor verpleeghuisopname te zijn. Deze bevindingen wijzen erop dat er sprake is van een tamelijk vast omschreven doelgroep voor de verpleeghuisdagbehandeling.

Omdat in dit transversale onderzoek twee gescheiden onderzoekspopulaties werden vergeleken, respectievelijk de groep opgenomen en de groep ontslagen. dagbehandelingspatiënten in 1995, wordt gepleit voor het verrichten van prospectief onderzock, waarbij patiěnten van opname tot ontslag gevolgd worden.

Samenvattend wordt uit deel 2 duidelijk dat verankering van nieuwe verpleeghuisfuncties erg gebaat is met uitgebreider en gedegen evaluatie-onderzoek.

Het merendeel van het wel beschikbare Nederlandse onderzoek naar (determinanten van) ouderenzorg is gebaseerd op cross-sectioneel onderzoek, dat zich bovendien vrijwel exclusief richt op de thuiszorg. Het gebruik van bevolkingssteekproeven, waarin weinig patiënten van verpleeghuizen en ook weinig bewoners van verzorgingshuizen voorkomen, ligt hieraan mede ten grondslag. ${ }^{23}$ Bovendien zijn er dus vaak problemen bij het recruteren van verpleeghuispatiënten in een onderzoekspopulatie. Deze aan cross-sectionele onderzoeken inherente beperkingen betekenen dat er geen causale relaties vastgesteld kunnen worden tussen diverse kenmerken van ouderen en het gebruik van een breed scala aan zorgvoorzieningen. Daarvoor zijn beloopstudies naar het gebruik van zorg 142 nodig. Het is dus logisch dat er steeds meer stemmen opgaan voor het verrichten van longitudinaal én multidisciplinair onderzoek ter onderbouwing van het integrale ouderenbeleid van de overheid, alsmede om meer richting te geven aan een doelmatige en effectieve zorgverlening aan ouderen. Tevens om de effecten van het voorgestane substitutiebeleid beter te kunnen vaststellen.' Voor het verrichten van dergelijke studies is de ontwikkeling van een specifiek en integraal patiënt-beoordelings- én volgsysteem van belang, waarmee pariënten gedurende hun hele "medische- en zorgcarrière" gevolgd kunnen worden, zowel extramuraal als semi- en intramuraal.' Ten aanzien van het toekomstige onderzoek in de verpleeghuisgeneeskunde en de verpleeghuiszorg kan in dit verband gewezen worden op de nu in enkele Nederlandse verpleeghuizen lopende onderzoeken met het internationale Resident Assessment Instrument (het RAI-systeem). ${ }^{6}$ Dit patiëntbeoordelingssysteem wordt niet alleen in de Verenigde Staten, maar ook in andere Europese landen dan Nederland gebruikt. Bij gebleken geschiktheid zou bredere implementatie het op termijn mogelijk maken dat de Nederlandse verpleeghuispopulatie en verpleeghuiszorg beter vergeleken kunnen worden met die van residentiële zorginstellingen elders in de wereld.

De samenwerking verpleeghuisarts - huisarts nader onderzocht

Deel 3 van het proefschrift, gaat nader in op de samenwerking russen verpleeghuisarts en huisarts.

In paragraaf 3.2 wordt de actualiteit van deze samenwerking in algemene zin gepositioneerd.

Uit ons onderzoek, zoals weergegeven in de paragrafen $3.3,3.4$ en 3.5 , wordt duidelijk dat er nog nauwelijk sprake is van een breed verpreide zorginhoudelijke 
samenwerking tussen huisarts en verpleeghuisarts. Daar waar de onderlinge samenwerking tussen verpleeghuisartsen en huisartsen, rondom verpleeghuizen, wel meer gestalte heeft gekregen, hangt deze samen met voor de hand liggende elementaire samenwerkingsprincipes.

Geconcludeerd wordt dat de samenwerking tussen huisarts en verpleeghuisarts beter tot stand komt in minder verstedelijkte gebieden en daar waar goede onderlinge samenwerkingsafspraken gemaakt zijn en beiden samen bij de zorg betrokken zijn. En voorts ook daar waar verplecghuizen bij het genereren van innovatieve transmurale projecten een financiële vergoeding voor de huisarts hebben opgenomen. Regelmatig en adequaat onderling werkcontact russen huisarts en verplecghuisarts blijkt eveneens bij te dragen aan een betere continuïteit van de medische zorg.

Bevorderende factoren daarvoor zijn:

- het belang dat zowel huisarts als verpleeghuisarts hechten aan cen goede onderlinge samenwerking;

- het feit dat huisartsen kennis hebben van, waardering hebben voor en belang hechten aan de expertise van het verpleeghuis en van de verpleeghuisarts;

- de aanwezigheid van verpleeghuisartsen die zijn toegerust voor samenwerking, doordar ze voldoende kennis hebben van de mogelijkheden van de huisarts alsmede van andere samenwerkingspartners;

- het investeren van tijd door zowel de huisarts als de verpleeghuisarts in de onderlinge samenwerkingsrelatie.

\section{Samenwerking en zorgnetwerken}

In algemene zin is afstemming tussen de behandelingen en zorgpakketten van verschillende zorgaanbieders nodig om een continue en integrale zorg te kunnen bieden."

Strategisch gezien is het fenomeen van de samenwerking dan ook een actueel item geworden in de ouderenzorg. Recente ontwikkelingen wijzen erop dat veel zorgaanbieders in toenemende mate, zij het in het begin experimenteel, kiezen voor netwerkachtige constructies." Deze ontwikkeling wordt versterkt door de transmuralisering van de zorg. Hierbij, wordt de zorg niet langer meer op de traditionele plaats gegeven, maar zo mogelijk daar waaraan de patiènt de voorkeur geeft; het individuele zorgproces staat centraal. Andere achtergronden zijn het, mede van overheidswege, voorgestane streven naar de-institutionalisering en zorgsubstitutie.

Het feit dat bij transmurale zorgverlening de patiènt gevolgd wordt door de zorgaanbieders heeft wel als consequentie dat er "nieuwe" toetreders op de extramurale zorgmarkt komen. Zo bieden verpleeghuis en verzorgingshuis ook zorg aan huis en levert het ziekenhuis zorg buiten de muren ("ziekenhuisverplaatste-zorg").

Deze transmuraliteit vraagt automatisch om samenwerking tussen de verschillende beroepsgroepen/zorgaanbieders: wijkverpleegkundige - ziekenverzorgende, verpleeghuisarts - verzorgingshuis, verpleeghuisarts - huisarts, huisarts - verzorgingshuis, wijkverpleegkundige/-verzorgende - huisarts, huisarts - specialist, verpleeghuisarts - specialist, verpleeghuis - ziekenhuis, verzorgingshuis - ziekenhuis, verpleeghuis - verzorginsghuis etc. Men duidt hier ook wel op de "zorgketen": het primaire proces van de zorgverlening.' 
Is de samenwerking in de as huisarts-medisch specialist-verpleeghuisarts onder meer van belang voor de continuïteit van de medische zorg; voor deze medische disciplines is ook de afstemming met andere hulpverleners van belang. Zo blijkt uit ons onderzoek dat alle responderende huisartsen in de dagelijkse praktrijk van de ouderenzorg in zeer hoge mate waarde hechten aan de samenwerking met de wijkverpleegkundige. De helft tot meer dan de helft vindt bovendien de samenwerking met het maatschappelijk werk, de gezinszorg, de eerstelijns-fysiotherapie en de RIAGG van belang.

Op vergelijkbare wijze maken de ziekenhuisverplaatste zorg in verpleeghuizen (die bijvoorbeeld leidt tot een steeds sterkere profilering van de revalidatiefunctie van het verpleeghuis) en de verpleeghuisverplaatste zorg zelf, ook voor de verpleeghuisarts en het verpleeghuis, de samenwerking met andere hulpverleners/ zorgaanbieders van buiten het verpleeghuis in toenemende mate belangrijk. Ook dit wordt bevestigd in ons onderzoek waarin de meeste responderende verpleeghuisartsen met name het belang van de samenwerking met de thuiszorg, de eerstelijns-fysiotherapie en de RIAGG aangeven.

Heeft de verpleeghuisverplaatste zorg in de afgelopen jaren al geleid tot een sterk toenemende samenwerking tussen verpleeghuizen en verzorgingshuizen, de laatste tijd ziet men ook de samenwerking tussen verpleeghuizen en thuiszorg geleidelijk aan meer gestalte krijgen.

De voorgestane ontwikkeling van de genoemde netwerkachtige samenwerkingsconstructies zal daarmee inderdaad steeds meer gestalte krijgen. Een daarvoor noodzakelijk plan van "aanpak modernisering AWBZ", waarin onder andere de integrale zorg door verpleeghuis, verzorgingshuis en thuiszorg zijn opgenomen is. hiervoor inmiddels reeds beschikbaar. ${ }^{10}$

De samenwerkingsverbanden die inmiddels her en der in de ouderenzorg ontstaan, zijn pluriform en kunnen algemeen (zorgconcerns) óf ziektegericht dan wel specifiek zijn (netwerken voor CVA-zorg of voor psychogeriatrische zorg). Ze worden van overheidswege uit gefaciliteerd met subsidies uit een zorgvernieuwingsfonds.

Een belangrijk motief om te gaan samenwerken is dus gelegen in zorginhoudelijke en kwalitatieve overwegingen, veelal gerelateerd aan het primaire proces. Samenwerking tussen verschillende hulpverleners kan leiden tot een betere afstemming van het aanbod op de vraag en daarmee leiden tot kwaliteitsverbetering van de zorg: verbetering in de continuïteit van zorg, zorg-op-maat en patièntgerichter handelen. ${ }^{\text {ste }}$

Uiteraard geldt hier opnieuw dat deze verwachte positieve gevolgen van samenwerking onderbouwd zouden moeten worden door middel van longitudinaal en ook multidisciplinair onderzoek.

Terugkomend bij de huisarts en de verpleeghuisarts kan vastgesteld worden dat zij in dit verband ook beschouwd moeten worden als samenhangende elementen in een zorgnetwerk. Hun samenwerking kan, analoog aan de relatie huisartsmedisch specialist, concreet omschreven worden als het totaal van de op elkaar afgestemde activiteiten, gericht op de ondersteuning van elkaars beroepsuitoefening. ${ }^{1.12} \mathrm{Er}$ bestaan vervolgens twee mogelijke vormen, namelijk de sequentiële samenwerking met "opvolgende afhankelijkheid" (bijvoorbeeld bij opname van een patiènt in het verpleeghuis) en de integrale samenwerking met aanvullende 
afhankelijkheid (bij patiènten waarbij ze samen betrokken zijn, zoals dagbehandelingspatiènten en substitutiezorgpatiēnten). ${ }^{*}$ Samenwerking staat of valt daarbij in het eerste geval met de onderlinge communicatie (goede overdracht) en in het tweede geval met de onderlinge afstemming." In het verlengde hiervan passen ook de resultaten van ons eigen onderzoek.

\section{Consultatie}

In de praktijk zullen samenwerkingsprocessen de tijd moeten krijgen om rustig uit te kristalliseren.

Knelpunten, zoals ook aangegeven in ons onderzoek, kunnen opgelost worden door het maken van goede samenwerkingsafspraken en/of samenwerkingsprotocollen.'

Een in het initiële stadium vaak adequate vorm van samenwerking blijkt "consultatie" te zijn. Consultatie is een vorm van samenwerking waarbij kennisoverdracht en deskundigheidsbevordering plaatsvinden. Er bestaan diverse vormen zoals telefonische consultatic, diagnostische consultatic, consultatiebijeenkomsten, consultatieve verwijzing en gezamenlijke consultatie. ${ }^{\text {.13 }}$

Het consultatiemodel heeft zijn waarde in de relatie huisarts-medisch specialist reeds bewezen. " Ook in ons onderzoek krijgt het als samenwerkingsvorm adhesie van huisartsen en verpleeghuisartsen, waaruit afgeleid mag worden dat frequente wederzijdse consultatie een goed uitgangspunt is bij het verder vormgeven van de samenwerking tussen huisarts en verpleeghuisarts. Een conclusie die ook past bij de in dit verband door de Landelijke Huisartsen Vereniging (LHV) en de Nederlandse Vereniging van Verpleeghuisartsen (NVVA) uitgebrachte nota."

Aan huisartsen en verpleeghuisartsen derhalve nu de taak om locaal/regionaal de onderlinge (transmurale) samenwerking op basis van goede afspraken en gelijkwaardige betrokkenheid nader vorm te geven en te laten uitgroeien tot een voor de patiëntenzorg wenselijke vorm.

Verpleeghuisartsen en huisartsen zullen daarbij ook meer dan ooit voorbereid moeten worden op samenwerkingsprocessen in de gezondheidszorg:

Het merendeel van de aan ons onderzoek participerende huisartsen en verpleeghuisartsen vindt het belangrijk dat er in de basis- en vervolgopleidingen aandacht besteed wordt aan de wederzijdse beroepsinhoud én is er ook van overtuigd dat de onderlinge samenwerking bevorderd kan worden door het samen ontwikkelen en volgen van bij- en nascholing.

Bij de herziening van het curriculum voor de opleiding tot basisarts zou derhalve, in het verlengde van de transmurale ontwikkelingen in de gezondheidszorg, meer aandacht aan samenwerkingsfenomenen geschonken moeten worden. De bureaus, respectievelijk de organisatoren van post-academisch onderwijs zouden zich eveneens meer moeten richten op multi- en interdisciplinaire nascholingsprogramma's. Daarbij zouden scholingsactiviteiten die uitgaan van een probleemgerichte benadering de voorkeur verdienen, omdat deze de multi- of interdisiciplinair samenwerkende disciplines zullen dwingen om samen te denken over en te werken aan oplossingen voor gepresenteerde complexe problematiek.

Tenslotte zou in de beroepsopleidingen tot huisarts en verpleeghuisarts gedacht kunnen worden aan het organiseren van gezamenlijke terugkomdagen voor huisartsen- en verpleeghuisartsen-in-opleiding, waarbij, naast de kennismaking 
met elkaars werk, specifieke aandacht besteed kan worden aan problematiek die zich voordoet op de raakvlakken van beide vakgebieden.

Initiatieven hiervoor lopen, zoals aangegeven, reeds aan de Universiteit van Nijmegen. ${ }^{16}$

\section{De samenwerking huisarts- verpleeghuisarts in breder perspectief}

Hieronder wordt nog dieper ingegaan op enige andere aspecten, die passen binnen het analyse-model van de samenwerking (paragraaf 3.5), voor zover ze niet zijn besproken in ons eigen onderzoek.

Voor de realisering van een goede onderlinge samenwerking zijn ook ontwikkelingen binnen de beroepsgroepen van de huisartsen en verpleeghuisartsen van belang.

Zo zullen huisartsen in de toekomst meer collega-georiënteerd moeten worden, in plaats van louter patiënt-georiënteerd. ${ }^{17}$ Tot voor kort waren huisartsen in het primaire proces immers maar in beperkte mate taakafhankelijk van andere zorgverleners. Voor het merendeel van de hulpvragen kon de huisarts ook zonder of alleen met ad hoc samenwerking volstaan. Een veelgehoorde opvatting onder huisartsen, die in feite ook naar voren komt uit ons eigen onderzoek, is: "Als we als huisarts behoefte hebben aan overleg, nemen we daar zelf wel het initiatief voor en dan komi er ook overleg":

Uit ons onderzoek en dat van anderen blijkt dat de te verwachten frequentere confrontatie met (oudere) patiënten, die een complexe hulpvraag hebben, de

146 huisarts meer taakafhankelijk van anderen zal maken."

Verpleeghuisartsen op hun beurt, die gewend zij̣n om vanuit een regierol samen te werken. in een systeem van continue, langdurige, systematische en multidisciplinaire zorg, zullen primair vanuit een complementaire invalshoek bij moeten dragen aan de samenwerking mer huisartsen.

Het gegeven dat er in de zorg een groeiende wederzijdse afhankelijkheid te verwachten is, moet gekoppeld aan het dreigende artsentekort in Nederland, moet daarbij eveneens voldoende voedingsbodem zijn voor een goede, door middel van afspraken gereguleerde, samenwerking.

Naast de actuele ontwikkelingen kan de samenwerking tussen hulpverleners in de gezondheidszorg ook bezien worden vanuit een sociologische invalshoek.

Zo heeft Kersten, om een beter begrip te krijgen van de relatie huisarts-specialist teruggegrepen op de sociale uitwisselingstheorie van Thibaut en Kelley. ${ }^{13}$ De basis van die theorie houdt in dat mensen in hun relaties streven naar zo groot mogelijke "baten" en zo weinig mogelijke "kosten".

Naast dit "kosten-baten"-principe worden ook andere determinanten van samenwerking onderscheiden: "afhankelijkheid", "macht" en "invloed" ten opzichte van elkaar in de relatie én de situatie waarin deze relatie vorm moet krijgen. ${ }^{\text {tenosi }}$ Tenslotte kunnen ook "normen" ontstaan danwel vastgelegd worden, waarmee gedragsregels van kracht worden voor personen die een relatie met elkaar hebben. Optimale samenwerking is waarschijnlijk het beste te realiseren vanuit een "winwin"-situatie voor elk van de in de relatie participerende hulpverleners. Wederzijdse "afhankelijkheid" is in de relatie huisarts/verpleeghuisarts niet zo sterk aan de orde. Selectie-invloed op basis van verwijspatroon speelt nauwelijiks een rol. Capacitair 
gezien is in de verpleeghuiswereld bovendien sprake van een schaarstemodel.

De principes van "macht" en "(zorg)invloed" beginnen pas de laatste jaren een rol te spelen, in relatie tot de domeindiscussie die ontstaan is nu verpleeghuizen en dus ook verpleeghuisartsen mogelijkheden hebben gekregen om in de eerstelijn te gaan acteren.

De discussie omtrent wie in de toekomst in de verzorgingshuizen de eindverantwoordelijkheid voor de medische zorg moet gaan dragen, is daarbij het meest pregnant en voor de beroepsverenigingen ook aanleiding om een en ander samen te gaan regelen.

Welke baten zijn er dan voor de huisarts en verplecghuisarts te onderscheiden aan een onderlinge samenwerking?

Wat betreft de financiële aspecten is het zo dat een verplecghuisarts in loondienst werkt en een huisarts op abonnementsbasis. Voor een verpleeghuisarts zijn er aan de samenwerking met de huisarts geen financiële voordelen verbonden. Samenwerking met betrekking tot patiënten die in het verpleeghuis opgenomen moeten worden, biedt ook aan de huisarts geen financiële incentives. Bezocken van opgenomen patiënten of betrokken willen zijn bij beslissingen omtrent de zorgverlening in het verpleeghuis, zijn sterk afhankelijk van de taakopvatting van de individuele huisarts. Baten liggen hier dus vooral in de ideologische sfeer. Expressie ervan betekent tijdsinvestering en extra werkbelasting.

Ten aanzien van de dagbehandeling zijn er voor zowel huisarts als verpleeghuisarts ook geen financiële prikkels verbonden aan samenwerkingsactiviteiten. Samenwerking zal zich ook hier dus primair vanuit ideologische, zorginhoudelijke en professionele gronden moeten ontwikkelen. (Ideologische baten!)

Substitutie-activiteiten leveren voor de huisarts veelal ook geen financiële voordelen op, terwijl er in hun optiek wel vaak meer inspanning en tijdsinvestering van hen verwacht worden, in relatie tot de uitvoering van de gegeven adviezen vanuit het extramuraal werkende verpleeghuis. Een financiële prikkel kan hier overigens wel positieve gevolgen hebben, zoals uit ons onderzoek is gebleken. Eventueel toekomstig verlies van het verzorgingshuis als "huisartsendomein" levert wellicht wel financiële nadelen op.

Een derde aspect, dat op een of ander wijze invloed kan hebben op de onderlinge samenwerking tussen verpleeghuisarts en huisarts, heeft te maken met de beroepsontwikkeling en de positie in het veld van de gezondheidszorg van respectievelijk de huisarts en de verpleeghuisarts.

De crux van het medische professiebegrip is dat een specifiek en door de overheid gelegitimeerd beroep, eigen kennis bezit en vanuit die kennis een zekere mate van autonomie krijgt, voor wat betreft de opzet en uitvoering van de eigen dienstverlening. Deze specifieke kennis en kunde leiden ertoe dat beoefenaren van het betreffende beroep vervolgens een claim leggen op een bepaald domein in het totale veld van de gezondheidszorg. ${ }^{2.23}$ Autonomie en eigen domein kunnen alleen worden verworven en blijven bestaan als daarvoor maatschappelijke erkenning bestaat. Daarom moet een professie ervoor zorgen dat er continue aansluiting blijft bestaan met veranderende maatschappelijke eisen. Professionalisering wordt daarmee ook tot een dynamisch fenomeen. Legitimatie moet voortdurend opnieuw bevestigd worden. ${ }^{24}$

Professionalisering krijgt onder andere gestalte via een eigen opleidingsstructuur 
en beroepsspecifiek wetenschappelijk onderzoek, maar ook in belangrijke mate door het realiseren van een collectief verworven machtspositie. ${ }^{24}$ Een beroepsgroep moet de leden steeds kunnen normeren in het licht van een voortdurend veranderend maatschappelijk tijdsbeeld. Het middel daarvoor is de beroepsorganisatie (voor huisartsen de Landelijke Huisartsen Vereniging (LHV) en voor verplecghuisarisen de Nederlandse Vereniging van Verpleeghuisartsen (NVVA)). Het professionaliseringsproces van zowel de huisarts als de verpleeghuisarts wordt sterk beïnvloed door maatschappelijke en politieke ontwikkelingen. Overheid en patiènten stellen steeds meer eisen aan de gezondheidszorg. De zorg dient clièngericht en vraaggericht te worden in plaats van aanbodgericht. Van professionals wordt verwacht dat zij verantwoording afleggen voor hun zorgactiviteiten ${ }^{3}$ the

Van de Rijde-van de Ven onderscheidt in haar proefschrift drie fasen in het professionaliseringsproces van de huisartsgeneeskunde. "In de periode voor 1975 was sprake van de afbakening van een eigen domein (inclusief oprichting van de LHV (1945) en het Nederlands Huisartsen Genootschap (NHG) (1956)). In de periode van 1975 tot 1987 was sprake van bescherming van het domein door institutionalisering en legitimering (Basistakenpakket 1983, Convenant Overheid en LHV 1985, waarin onder andere andacht voor de beroepsopleiding, de financiering van deskundigheidsbevordering, de goodwilliregeling en het vestigingsbeleid). De periode van 1987 tot 1991 , waarin politiek-maatschappelijk steeds meer aandacht kwam voor de marktwerking en de functiegerichte benadering in de zorg, was een periode van specifieke aandacht voor de interne normering, waarbij de vastgestelde taakomschrijving van de huisarts, ook met het oog op de toekomstige positie, tot interne norm verheven werd. Het NHG had inmiddels het standaardenbeleid opgezet, waarmee ook een basis werd gelegd voor verdere normontwikkeling in de toekomst. De LHV zette een beleid uit voor versterking van de beroepsorganisatie, het kwaliteirsbeleid en de versterking. van de centrale positie van de huisarts.

Duidelijk was inmiddels geworden dat de breedte van het werkterrein, in combinatic met de veelal solistische uitvoering en de pas sinds 1975 bestaande specifieke aandacht voor de institutionalisering van het beroep, ertoe bijgedragen hadden dat huisartsen onderling sterk verschilden in hun praktijkuitvoering. Het inmiddels op gang gekomen wetenschappelijk onderzoek in de huisartsgeneeskunde bevestigde dit beeld. Voor de versterking van de toekomstige positie van de huisarts zou derhalve gestreefd moeten worden naar een situatie waarin de verschillen tussen individuele huisartsen, met betrekking tot hun praktijkuitvoering, tot aanvaardbare proporties worden teruggebracht. Een belangrijk middel om deze beleidsdoelstellingen te verwezenlijken werd gezien in de huisartsengroep (HAGRO) en in de nadere profilering van het standaardenbeleid. ${ }^{12}=$ Op beide terreinen is het afgelopen decennium dan ook het nodige gebeurd. Inmiddels is er bovendien een systeem van verplichte nascholing/ toetsing opgezet, gekoppeld aan de herregistratic.

Daarbij is er ten aanzien van het behoud van de centrale positie van de huisarts in de gezondheidszorg de afgelopen jaren ook veel te doen geweest over diens "poortwachtersfunctie" en over diens regierol in de thuiszorg. Desalniettemin zijn er, ook uit onderzock, aanwijzingen dat deze beide laatste functies vooralsnog onvoldoende uit de verf komen. In hun poortwachtersrol lijken huisartsen 
bijvoorbeeld nog onvoldoende selectief te verwijzen naar de tweedelijn en ook te weinig de continuïteit van zorg met betrekking tot door hen verwezen patiënten te bewaken. piss

Bij zorgvernieuwing in de ouderenzorg of thuiszorg en bij de ontwikkeling van regiovisies blijken huisartsen wel vaak als participant betrokken doch niet zozeer als initiatiefnemer. "Nava Daarbij zijn de banden van huisartsen met andere gezondheidszorgvoorzieningen nog vaak te zwak." Een en ander kan uiteindelijk, voor wat betreft de rol van de huisarts in de coördinatie en de organisatie van de zorg, een bedreiging vormen voor hun domein in relatie rot de thuiszorg en het verzorgingshuis.

Alles overziende, is het duidelijk dat de huisartsgeneeskunde de afgelopen decennia een eigen positie heeft opgebouwd, waarbij het generalistische karakter de basis van dit domein vormt. Er is veel aandacht besteed aan de opbouw van het vakgebied. Politiek-maatschappelijke ontwikkelingen (waaronder het streven. naar betere samenhang en toegankelijkheid van de zorg, naar een grotere invloed van de patiënten en naar kostenbeheersing) beïnvloeden echter de traditionele visic op de autonomie van de professional, zo ook die van de huisarts. Werken aan de kwaliteit van de huisartsgeneeskundige zorg, aan versterking van het groepsgewij̨s opereren (Huisartsengroep (HAGRO)/ Huisartsen Onder Een Dak (HOED)) en aan het sluiten van de gelederen binnen de beroepsgroep worden daarop als antwoorden gezien. Specifieke aandacht voor de samenwerking met andere partijen in de gezondheidszorg zal daarvoor eveneens belangrijk zijn.

Ten aanzien van de professionalisering van de verpleeghuisgeneeskunde kan in het verlengde van bovenstaande het volgende opgemerkt worden.

Nadat in 1968, met de invoering van de Algemene Wet Bijzondere Ziektekosten (AWBZ), het verpleeghuis als instituut binnen de Nederlandse gezondheidszorg was erkend, kwam deze erkenning voor het vakgebied van de verpleeghuisgeneeskunde pas in 1989-1990, met de start van een eigen opleiding tot verpleeghuisarts (1989) en de opening van een eigen register in 1990. Het specifieke van de medische zorg voor patiënten, opgenomen in een verpleeghuis (= het domein) werd daarmee dus pas een decennium geleden ook maatschappelijk erkend. De verpleeghuisgeneeskunde kreeg daarmee ook een eigen identiteit tussen de generalistische huisartsgeneeskunde en de specialistische geriatrie. . $^{\text {it }}$

Realiseren van deze registratie en erkenning van verpleeghuisartsen, alsmede van een eigen opleiding zijn belangrijke taken geweest van de Nederlandse Vereniging, van Verpleeghuisartsen (NVVA), die in 1972 werd opgericht. De eerste 20 jaar hield deze vereniging zich dus met name met de inhoud van het beroep bezig; een vergelijkbare ontwikkeling als genoemd bij de huisartsgeneeskunde. Een ander streven, namelijk het genereren van wetenschappelijk onderzock op het gebied van de verpleeghuisgeneeskunde, heeft wel een kleine impuls gekregen door de start van de eigen beroepsopleiding, maar aan het einde van de negentiger jaren zijn er in dezen nog nauwelijks structurele onderzoekslijnen van de grond gekomen.

Ten behoeve van de verdere ontwikkeling van de verpleeghuisgeneeskunde zal derhalve nog veel energie gestoken moeten worden in de realisering van. een beter onderzoeksklimaat, in de motivering en scholing van verpleeghuisartsonderzoekers

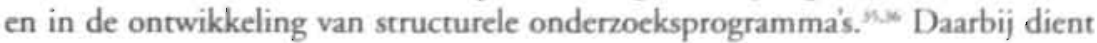


ook rekening gehouden te worden met het specifieke probleemgeoriënteerde karakter van de verpleeghuisgeneeskunde en met het feit dat deze veelal in multidisciplinair verband uitgeoefend wordt binnen de totale en integrale verpleeghuiszorg, die patiënten in het verpleeghuis ontvangen.

Wat betreft de aard van het verpleeghuisgeneeskundig onderzoek blijft er, zoals eerder aangegeven, in grote liinen een primaire behoefte bestaan aan kwalitatief verantwoord epidemiologisch onderzoek, aan longitudinaal observationeel en experimenteel patiëntgebonden beloops- en interventie-onderzoek en aan de ontwikkeling plus validering van voor de verpleeghuispopulatie geschikte meetinstrumenten en uitkomstmaten. ${ }^{35.60}$

Integratie van verpleeghuiszorgonderzoek en verpleeghuisgeneeskundig onderzoek kan bereikt worden door in patiëntgebonden onderzoek na te gaan wat de structuur van de verpleeghuiszorg voor invloed heeft op het zorgproces in het algemeen en de medische zorg in het bijzonder. Aspecten zoals leefklimaat, de beschikbaarheid en deskundigheid van verpleeghuismedewerkers en de wijze waarop de context van het verpleeghuis veiligheid en ondersteuning biedt, hebben immers een duidelijke invloed op de uitkomst van het totale zorgproces. $\$ .30$

Naast de noodzakelijke verdere profilering van het onderzoek zal aandacht voor de inhoud van het verpieeghuisgeneeskundige beroep het komende decennium ook belangrijk blijven, waarbij bijvoorbeeld de ontwikkeling van eigen standaarden en de implementatie van een eigen bij- en nascholingstraject in het kader van de herregistratie genoemd mogen worden. Ten aanzien van dergelijke ontwikkelingen loopt de verpleeghuisgeneeskunde derhalve nog achter bij de huisartsgeneeskunde, maar is wel een analoog vervolgtraject voorstelbaar.

Een opmerkelijk feit is nog dat de erkenning van de verpleeghuisgeneeskunde kwam in een tijd waarin de verpleeghuiszorg zich tevens meer extramuraal begon te profileren en de verpleeghuisgeneeskunde zich ook in het domein van de huisarts begon te bewegen.

Tor op de dag van vandaag staat het extramurale domein van de verpleeghuisarts nog niet vast; ook al is de complementaire verpleeghuisgeneeskundige inbreng in het verzorgingshuis inmiddels gemeengoed geworden.

Demografische ontwikkelingen, wachtlijsten in de zorgsector, het overheidsstreven naar versterking van de thuiszorg en de wens van veel ouderen met een complexe hulpbehoefte, om zolang mogelijk in de eigen woonomgeving te kunnen blijven, leiden er als het ware toe dat steeds meer patiënten substituerende verpleeghuiszorg thuis nodig zullen hebben. In het verlengde hiervan vinden inmiddels al in het hele land zorgvernieuwingsexperimenten plaats."

Uiteraard is hierbij ook de rol van zowel huisarts als verpleeghuisarts in het geding.

In de nabije tockomst zal naar verwachting de onderlinge samenwerking vanuit huisartsenzijde met name ondersteund worden als de huisarts de medische regie in de eerstelijn blijft behouden en de inbreng van de verpleeghuisarts aldaar primair consultatief en complementair van aard zal blijven.

Zorginhoudelijk zal de verpleeghuisarts, vanuit zijn loondienstverband, overigens primair zijn expertise inzake de zorg voor patiënten met meervoudig complexe hulpvragen willen "exporteren" en niet zijn medisch territorium willen uitbreiden. Uitgaande hiervan is verdere ontwikkeling van de samenwerking dan ook met 
name te relateren aan het ideologische "continuïteitsbeginsel"; dus het zich, "vanuit een professional partnership", met respect voor elkaars expertise, samen verantwoordelijk weten voor de continuïteit van medische zorg. 


\section{UTIERATUUR}

1. Robben PBM, Olde Rikkert MGM, Husechemackers GJM. Beroepsvorming in tweevoud: de klinisch geriater en de verpleeghuisarts, 1945-1990. Tijdschr Gerontol Geriatr 1999; 30; 55-63.

2. Schrijvers AJP. Een kathedraal van zorg. Utreche De Tijdstroom, 1993.

3. Kempen GIJM, Ormed J, (red), Dagelijks funcrioneren van ouderen. Assen: Van Gorcum, 1996.

4. Huijsman R, Klerk M de. Succesvolle zorgverlening aan ouderen in Nederland. Een overzichr van beleidsontwikkelingen en onderuocksinzichten. TSG 1997; 75; 406-16.

5. Veer AJE de, Kerkstra A. Vetpleeghuiszorgonderzoeks stand van zaken en relevante onderzoeksvelden. Utrecht: NIVEL 1997 .

6. Morris JN, Hawes C. Fries BE. Designing the National Resident Assesment Instrument for Nursing Homes. Gerontopist 1990: 30: 293-307.

7. Acherberg WP, Campen C van, Pot, AM, Kerkstra A, Ribbe MW. Effects of the Resident Assessment Instrument on the cate process and health outcomes in nursing home. A review of the literature. Scand I Rehab Med 1999; 31: 131-7.

8. Dokter H. Onrwikkelingen in her aanbod. In: Dokter H. e.a. (red). Zorg aan huis, een stand van zaken. Utrecht: De Tipdstroom, 1996: 13-30.

9. Brus, FR. Dekker RFW, Juch HR, (red). Ouderenzorg na 2000. Van kostbare samenwerking naar betaalbare amenhang. Waddinsveen: Scaudit Performance Group, 1996.

10. Zicht op zorg (plan van aanpak modernisering AWBZ). Den Haag VWS, 1999.

11. Jacobs HM, Melker RA de, Touw-Otten FWMM. Samenwerking tussen huisartsen en specialisten (1). Medisch Contact 1983; 38: 1599-601.

12. lacobs HM. Melker RA de, Touw.Onen FWMM. Samenwerking russen huisuresen en specialisten (2). Medisch Contact 1984: 39: 1629-32.

152 13. Have JIIM, Kolker $\perp$ ten. Consultatievormen huisure-specialist. Utrecht: Stichting O\&O, 1990.

14. Vierhout WPM. Het gezamenlijk consult van huisarts en specialist in de eerstelijn. Proefschrift. Maastriche: Universiteir Mastricht, 1994.

15. NVVA/LHV-nota "Arss en ouderen: uiddagende zorg. Een stap vooruit in de samenwer king tussen huisarts en verplecghuisars". Utreche: NVVN/LHV, 1998.

16. Lavripsen J. Schols JMGA. Gezamenlijke terugkomdag voor verplecghuisartsen en huisartsen in opleiding aan de KU te Nijmegen. In rubriek: Vanuit de opleiding. Tijdschr Verplecghuisgeneeskd 1999 (3):27-8.

17. Rijde-van de Ven AHJ van de. Huisartsengroepen, groei en grenzen. Proefschrift. Tilburg; University Press, 1994.

18. Kersten T]JMT: De invloed van huisartsen in de tweedelijn. Proefschrift. Utrecht: RU Utrecht, 1991.

19. Cook M. Perceiving others: the psychology of interpersonal perception. Londen: Methuen, 1979.

20. Holahauer FFO, Minden IJR van. Psychologies theorie en prakrijk. Leiden: Stenfert Krocie, 1985.

21. Krech D, Crutchfield RS, Ballachey EL Individual in society: a textbook of social psychology. New York: McGraw-Hill, 1962.

22. Freidron E. Profession of medicine. A study of the sociology of applied knowiedge. New York: Harper and Row, 1970.

23. Mok AL. Berocpen in actic. Bijdrage tot cen berocpensociologie. Meppet: Boom, 1973.

24. Krogr Th van der. Professionalisering en collectieve mache. Den Haag: Vuga, 1981.

25. Freidwon E. The changing nature of profestional control. Ann Rev Sociol 1984: 10: 1-20.

26. Relman SA. Assessment and accountability, the third revolution in medical care. New England J Mod 1988; 319: 1220-2.

27. NHG. Naar criteria voor kwaliteit. Standardenbeleid NHG. Utrecht: Nederlands Huisartsen Genootschap. 1987.

28. Verdenius W. Brands PJ, Oudlkerk HR. Over kwaliteissbeleid. De Huisars 1990(c): I(6): 24-6.

29. Boonckamp LCM, Roo AA de. Naar wie werwijsen huicartsen? Ontstaan en dynamick van verwijerelatics. Medisch Contact 1992:47: 733-6. 
30. Rakk A van, Thijuen L. Jongetius-de Gier G. Riraen W. Mur-Veeman I. Laten leven om re overleven. Evaluatie. Programima Zorgvernieuwingprojecten Thuisxorg van WVC. Voorgangsrapporage 1991. Masstricht: Rijksuniversiteir Limburg, Valugrocp Beleidswetenschap, 1992.

31. Knapen MHJM. Eerste nesultaten van coperimenten met thuisverpleging. Coobndinaricfunctie en molvendeling. Medisch Contact 1988: 43: 1083-8.

32. Searmans R, Mostert HA. Wie cobrdineert de aorg in de eerstelijn? Mediuch Contact 1989: 44: 87.9.

33. Verharen F. Haupemeijer H. Meurs R. Koondinatie: van Klusen toe Kocrsen. Een samenvating van de conclusies uit fase 2 van het ondernock nazr koödinatie in gerondtheidscentra. Driebergen: AO, Adviseurs voor organicatiewerk BV, 1989.

34. Chaudron P.P. Omzien naar zorg. Een maatschappijgeschiedenis van de verpleeghuisgeneeskunde. Leiden: Groen BV, 1997.

35. Ribbe MW, Ooms ME. Wal G van der, Eijk JThM. Wetenschappelijk ondernoek in de verplecghuisgenes. kunde: een voorwaarde voor profesaionalisering. Ned Tijdschr Geneeskd 1995; 139(36): 1851-5.

36. Wendte JF, Danse JAC Verplecghuiszorg. Overvichtsatudie naar Nederlandse literatuut sinds 1985. NCCZ reeks Zorg, opvang en begeleiding van chronisch sieken. Zoetermeen NCCZ, 1994.

37. NIVEL/NZ1/NCGv. Innovatie in de zorgector. Jarboek 1997. Utrecht: De Tijdstroom, 1997. 
SAMENVATTING 
In dit proefschrift zijn naast een algemene inleiding (deel 1) twee hoofdsecties (deel 2 en 3) te onderscheiden: "Vanuit institutionele zorgverlening naar extramurale zorgverlening" en "De samenwerking verpleeghuisarts - huisarts nader onderzocht". Daarna volgt nog het deel "Beschouwing en samenvatting" (deel 4). In een addendum ("Verpleeghuisgeneeskunde in ontwikkeling") worden voorbeelden van kleinschalig onderzoek bij verpleeghuispatiënten, dan wel populaties van ouderen gepresenteerd.

\section{Deel 1: Algemene inleiding, vraagstellingen en opbouw proefschrift}

In het eerste deel wordt ingegaan op het fenomeen extramurale verpleeghuiszorg. Deze wordt gepositioneerd in het brede kader van de hedendaagse transmurale zorg.

Vervolgens wordt aangegeven dat het proefschrift is opgebouwd uit onderzoeksactiviteiten, die gekoppeld kunnen worden aan een drietal voor de verpleeghuiszorg en verpleeghuisgeneeskunde belangrijke algemene onderzoeksvraagstellingen:

1. Welke doelgroepen maken gebruik van de verpleeghuiszorg (intra-, semi- en extramuraal)?

2. Welke zijn de effecten van de verpleeghuiszorg op de onder 1. genoemde doelgroepen?

3. Hoe staat het met de (transmurale) samenwerking tussen disciplines uit het verpleeghuis en disciplines daarbuiten?

Hieronder worden de onderzoeksactiviteiten, die samenhangen met deze vraagstellingen, nader samengevat in de volgorde van de opbouw van het proefschrift.

Deel 2: Van institutionele zorgverlening naar extramurale zorgverlening

Dit deel sluit aan op de hedendaagse ontwikkelingen in de ouderenzorg. Mede door capaciteitsproblemen in de zorg kan moeilijk tegemoet gekomen worden aan de groeiende zorgvraag in een sterk vergrijzende bevolking. In het toekomstige gezondheidszorgbeleid wordt substitutie van zorg, van gecompliceerd en duur (opname in gespecialiseerde instellingen van de tweede lijn) naar eenvoudig en goedkoop, (rondom de thuissituatie en in dagbehandeling) centraal gesteld om zodoende meer zorgbehoevende mensen re kunnen bereiken. Substitutie van zorgfuncties voor ouderen zal moeten leiden tot een versterking van de thuiszorg om daarmee tevens tegemoet te komen aan de wensen van veel ouderen om zo lang mogelijk thuis of in het verzorgingshuis te kunnen blijven wonen. Verpleeghuizen trachten in te spelen op deze ontwikkelingen door ondersteuning van de zorg buiten de eigen muren aan te bieden.

Er wordt nader ingegaan op de semi- en extramurale zorgmogelijkheden van het hedendaagse verpleeghuis.

Paragraaf 2.2 biedt ter illustratie een casuïstische beschrijving van een aantal patiënten onder de titel: "Opname in een verplecghuis: nood of deugd?". Deze casuïstiek maakt duidelijk dat de hedendaagse verpleeghuiszorg veel meer is dan het stereotiepe beeld dat sommigen ervan hebben. Behalve voor langdurige en terminale zorg komen veel patiënten voor revalidatie in het verpleeghuis. Ook komt een toenemend aantal patiënten voor de minder bekende functies als tijdelijke opvang, crisisopvang, kortdurende observatie en diagnostiek, en speciale zorg casu quo verpleging (beademing, comazorg etc.). Daarbij kan verpleeghuis- 
zorg in de vorm van consultatic, dagbehandeling en substitutie al ver vóór een uiteindelijke opname aangewend worden om een zo lang mogelijk verblijf thuis of in het verzorgingshuis te bevorderen.

In paragraaf 2.3 wordt een algemene inleiding gegeven op de hedendaagse zorgmogelijkheden die verplecghuizen hebben buiten hun eigen muren. Her betreft de dagbehandeling, de consultatiefunctie en de substitutieprojecten. In dit hoofdstuk wordt een lans gebroken voor meer en gedegen effectonderzoek bij nieuwe verpleeghuisfuncties. Daarbij wordt gepleit voor de ontwikkeling van een specifiek en integraal patiënt-beoordelings- én volgsysteem, waarmee pariēnten gedurende hun hele "medische- en zorgcarrière" gevolgd kunnen worden, zowel extramuraal als semi- en intramuraal.

Paragraaf 2.4 luidt: "Verpleeghuiszorg in beweging; een inventariserend overzicht van vijf substitutieprojecten verpleeghuiszorg".

Dit inventariserend onderzoek is verricht om inzicht te krijgen in het funcrioneren van vijf substitutieprojecten verpleeghuiszorg in verzorgingshuizen, van Streekverpleeghuis St. Agnes te Geertruidenberg (nu de Riethorst). De hoofddoelstelling van substitutie van verplecghuiszorg luidt: door adequate zorgverlening aan verpleeghuisgeìndiceerde verzorgingshuisbewoners uitstel of afstel van verpleeghuisopname realiseren. Door middel van interviews met 64 betrokkenen bij de projecten, alsmede door het versturen van enquêtes zijn ervaringsgegevens verzameld. Van uitstel of afstel van verplecghuisopname blijkt in een groot aantal gevallen sprake te zijn. In de periode 1991-1993 werden er van de 144 deelnemende verzorgingshuisbewoners slechts 11 alsnog in het verpleeghuis opgenomen. Wat de feitelijke zorgverlening betreft, kan in de vijf projecten nog veel verbeterd worden. Het gaat daarbij vooral om langere openingstijden van de groepsverzorging, om een optimalisering van het methodisch werken alsmede om de realisering van een efficiënt multidisciplinair overleg. Van echte verpleeghuiszorg is voorlopig nog geen sprake. Daarnaast blijkt de financiering van deze substitutieprojecten gecompliceerd en onzeker, omdat deze via verschillende kanalen verloopt en bovendien de continuïteit niet gewaarborgd is. Structurele zekerheid in dezen is alleszins geboden, ten behoeve van het beleid op langere termijn.

De titel van paragraaf 2.5 is: "Verplecghuisdagbehandeling: een groeiende functie voor een tamelijk vast omschreven doelgroep".

Het betreft een descriptief onderzoek naar de kenmerken van in 1995 opgenomen en ontslagen verpleeghuisdagbehandelingspatiènten. Gegevens werden ontleend aan het landelijke SIG Verpleeghuis Informatiesysteem (SIVIS), een pariëntgebonden registratie, waaraan in 1995 meer dan $85 \%$ van de verpleeghuizen deelnam. Van de startende dagbehandelingspatiënten was $89 \%$ ouder dan 65 en $39 \%$ ouder dan 80 jaar; zij werden verder gekenmerkt door een slechts geringe oververtegenwoordiging van vrouwen ( $9 \%$ meer dan mannen), en door een morbiditeitspatroon van chronische aandoeningen (somatiek: cva 45\%; psychogeriatrie: dementie $80 \%$ ). Deze morbiditeit ging gepaard met een aanzienlijke invaliditeit en beperkingen van de mobiliteit. De meeste patiënten $(78 \%)$ komen vanuit het eigen huis. Zowel somatische als psychogeriatrische 
patiënten bezochten van opname tot ontslag gemiddeld driekwart jaar de dagbehandeling. Voor ruim $10 \%$ van de somatische en $40 \%$ van de psychogeriatrische patiënten mondde de dagbehandeling uit in een (aansluitende) verpleeghuisopname. De afgelopen tien jaar is de dagbehandelingscapaciteit in Nederland fors toegenomen en parallel daaraan het aantal patiënten dat gebruik maakt van deze voorziening. De gemiddelde hulpbehoefte en behandelduur zijn in die periode ongeveer gelijk gebleven.

\section{Deel 3: De samenwerking verpleeghuisarts - huisarts nader onderzocht}

Transmuralisering van verpleeghuiszorg dwingt verpleeghuismedewerkers om in toenemende mate aandacht te besteden aan de samenwerking met andere zorgaanbieders en zorgverleners van buiten het verpleeghuis.

In dit verband wordt in dit deel specifiek aandacht besteed aan de samenwerking tussen verpleeghuisarts en huisarts. In het licht van de geschetste ontwikkelingen in de ouderenzorg ontstaan er mogelijkheden voor een nauwe samenwerking tussen verpleeghuisarts en huisarts. Aandacht voor deze samenwerking is niet alleen van belang vanuit inhoudelijk oogpunt, maar ook noodzakelijk vanwege de ontwikkelingen met betrekking tot de extramurale verpleeghuiszorg, waardoor verpleeghuisarts en huisarts elkaar frequenter zullen gaan ontmoeten. Het ligt voor de hand dat complementariteit in plaats van concurrentie in de zorgverlening uiteindelijk bepalend zal zijn voor het realiseren van een succesvolle transmurale samenwerking tussen beiden.

158 In paragraaf 3.2 wordt een literatuurstudie gepresenteerd, waarin de actualiteit van deze samenwerking gepositioneerd wordt. De historische ontwikkelingen in de relatie worden beschreven, de beide vakgebieden worden vergeleken en knelpunten in de onderlinge samenwerking komen aan de orde. Tenslotte wordt een viertal samenwerkingsmodellen genoemd.

Paragraaf 3.3 is getiteld "Contacten tussen verpleeghuisarts en huisarts". in 1996 vond in de regio Oosterhout/Dongemond, het verzorgingsgebied van Streekverpleeghuis de Riethorst in Geertruidenberg, een inventariserend onderzoek plaats naar de contacten tussen verpleeghuisartsen en huisartsen. Door de verpleeghuisartsen werden alle contacten $(n=363)$ geregistreerd, die zij in dat jaar met de huisartsen hadden over nieuwe patiënten, bij opname en na opname in 1996, in respectievelijk hẹ verpleeghuis, op de dagbehandeling en in de substitutieprojecten, alsmede de contacten aangaande de consultatiefunctie en de nietpatiëntgebonden aangelegenheden. Registratie geschiedde op een voorgestructureerd standaardformulier. In de contacten bleek vooral sprake te zijn van éénrichtingsverkeer. In 91 procent van de contacten ging het initiatief uit van de verpleeghuisarts. Ongeveer tweederde van de contactredenen had betrekking op "patiëntenoverdracht", Aangegeven wordt dat verder onderzoek noodzakelijk is om bredere en meer gedetailleerde informatie te verkrijgen omtrent het actuele niveau van samenwerking russen huisarts en verpleeghuisarts en omtrent de omstandigheden waaronder deze samenwerking geinntensiveerd kan worden. 
1998 werd aan de hoofden medische dienst van alle gecombineerde verpleeghuizen in Nederland $(\mathrm{N}=220)$ een korte vragenlijst toegestuurd over de samenwerking tussen verpleeghuisarts en huisarts. Er werd gekozen voor gecombineerde verpleeghuizen om in het onderzock op voorhand verschillen uit te sluiten, gerelateend aan de categorie van het verpleeghuis (alleen psychogeriatrisch, alleen somatisch of beide). Bovendien is op dit moment de ruime meerderheid van de Nederlandse verpleeghuizen gecombineerd. Van de deelnemende verpleeghuizen waren een aantal basiskenmerken bekend. De vragenlijst ging onder andere in op de frequentie van contacten tussen verpleeghuisartsen en huisartsen in het kader van de dagbehandeling, de consultatiefunctie en de substitutieprojecten. Daarnaast werd ook op aspecten ingegaan die specifiek met de substitutieprojecten te maken hadden: het wel of niet aanwezig zijn van formele afspraken met de huisarts, het wel of niet concreet samen bij de zorg betrokken zijn, het wel of niet gebruik maken van een gemeenschappelijk dossier etc.

De respons was bijna compleet $(98 \%)$. Uit de resultaten blijkt dat er in ons land inmiddels sprake is van een evidente transmurale profilering van de verpleeghuizen. Duidelijk wordt ook dat de frequentie van contacten tussen huisartsen en verpleeghuisartsen, in het kader van de verpleeghuisdagbehandeling, de consultatiefunctie en de substitutieprojecten, in het algemeen nog laag is. Daarmee werden de resultaten van het eerdere regionale onderzock rondom verpleeghuis de Riethorst ook landelijk bevestigd. Vastgesteld werd ook dat de samenwerkingsintensiteit in transmurale projecten positief beïnvloed wordt door de aanwezigheid van goede samenwerkingsafspraken, door gezamenlijke betrokkenheid bij de zorg en door een financiële prikkel voor de huisarts. In dit onderzoek is verder, met het oog op een nog te verrichten landelijk vervolgonderzoek, gepoogd twee extreme groepen van verplecghuizen te onderscheiden, namelijk een groep verpleeghuizen waarvan verwacht mocht worden dat er een nauwe samenwerking zal zijn met huisartsen en een groep waarbij dit niet het geval was. Een en ander geschiedde op basis van de geregistreerde contactfrequentie met huisartsen en is in feite ook gedaan omdat we op zoek waren naar parameters die invloed hebben op de onderlinge samenwerking. Omdat we uit eerdere onderzoeksresultaten al wisten dat de samenwerking nog beperkt is, meenden we de bedoelde parameters op deze wijze ook beter te kunnen achterhalen. De zodanig onderscheiden twee groepen verpleeghuizen werden op essentiële verschillen onderzocht. Hierbij bleek de urbanisatiegraad een belangrijke rol te spelen. Verpleeghuizen uit de groep van waaruit een meer intensieve samenwerking met huisartsen verwacht mocht worden, waren vaker gelegen in minder verstedelijkte gebieden. Bovendien bleken verpleeghuisartsen die in deze verpleeghuizen werken een minder hoge klinische werklast te hebben, hetgeen door ons als een mogelijke aanwijzing wordt gezien voor het feit dat zij daardoor wellicht meer tijd kunnen besteden aan extramurale activiteiten en samenwerking.

Paragraaf 3.5. In vervolg op het onderzoek van paragraaf 3.4 is een uitvoerig enquête-onderzoek verricht onder huisartsen en verpleeghuisartsen waarbij de onderlinge samenwerking gerelateerd is aan de uirkomstvariabele continuiteit van medische zorg. Uit de twee groepen verpleeghuizen, die onderscheiden werden in het onderzoek, zoals beschreven in paragraaf 3.4, zijn tweemaal twintig verpleeghuizen gekozen; in totaal dus veertig verpleeghuizen, waarvan alle 
verpleeghuisartsen en een twintigtal huisartsen uit de respectievelijke verzorgingsgebieden van deze instellingen in het onderzoek zijn opgenomen. Op basis hiervan zijn vervolgens een viertal groepen respondenten (2 groepen huisartsen en 2 groepen verpleeghuisartsen) onderscheiden.

Uit het onderzoek (respons huisartsen: $31,9 \%$; respons verpleeghuisartsen: $68,6 \%$ ) blijkt dat het eerdere onderscheid in twee groepen verpleeghuizen (met een intensieve respectievelijk minder intensieve samenwerking met huisartsen) gerechtvaardigd was. Zowel huisartsen als verpleeghuisartsen rondom verpleeghuizen, waarvan verwacht werd dat er een goede samenwerking met huisartsen zou zijn, geven aan dat er inderdaad frequenter onderling werkcontact is en dat men ook meer tevreden is over deze onderlinge samenwerking. Belangrijk is echter dat de resultaten er ook op wijzen dat in deze situatie sprake is van een betere continuïteit van medische zorg.

Ook uit dit onderzoek blijkt opnieuw dat nog steeds een aanzienlijk deel van de huisartsen en verpleeghuisartsen geen onderlinge werkcontacten hebben.

Op basis van onze onderzoeksresultaten kan derhalve geconcludeerd worden dat de samenwerking tussen huisarts en verpleeghuisarts beter tot stand komt in minder verstedelijkte gebieden, daar waar beiden samen bij de zorg betrokken zijn en ook daar waar verpleeghuizen bij het genereren van innovatieve transmurale projecten, een financiële vergoeding voor de huisarts overwegen. Frequenter

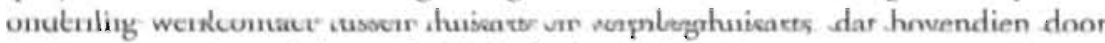
beiden als goed wordt beoordeeld, blijkt bovendien bij te dragen aan een betere continuïteit van medische zorg. Factoren die in dit verband, naast de urbanisatie160 graad, bevorderend kunnen werken zijn:

- het belang dat zowel huisarts als verpleeghuisarts hechten aan een goede onderlinge samenwerking:

- een bij huisartsen aanwezige opvatting dat het verpleeghuis in het algemeen en de verpleeghuisarts in het bijzonder inhoudelijk iets toe te voegen hebben aan de zorg;

- voldoende kennis bij huisartsen over de mogelijkheden van de verpleeghuisarts en andersom;

- het feit dat beiden de rijd die samenwerking kost niet teveel als knelpunt zien;

- een goede telefonische bereikbaarheid van de huisarts;

- het feit dat de wachtlijstproblematiek van verpleeghuizen voor huisartsen een stimulans zou kunnen zijn om ten behoeve van de betrokken patiënten nauwer samen te werken, om zodoende acceptabele oplossingen te vinden voor de overbruggingsperiode tot opname.

Verpleeghuisartsen geven in sterke mate aan dat huisartsen nu nog relatief vaak onbekend zijn met hun werk en de mogelijkheden van het verpleeghuis. Daarbij zijn huisartsen het er algemeen over eens dat men meer consultatief gebruik zou moeten maken van de verpleeghuisarts. Hiermee kan aangesloten worden bij het voorgestelde groeimodel, dat de Nederlandse Vereniging van Verpleeghuisartsen (NVVA) en de Landelijke Huisartsen Vereniging (LHV) voor de samenwerking tussen huisarts en verpleeghuisarts zijn overeengekomen en dat eveneens uitgaat van initiële consultatieve contacten.

In paragraaf 3.5 wordt maar zijdelings aandacht besteed aan de medische zorg in verzorgingshuizen, waar ook sprake is van een sterk groeiende zorgvraag. De 
domeindiscussie die hierover op koepelniveau wordt gevoerd, wordt in dit onderzoek bevestigd. Definitieve uitspraken over een model voor de tockomstige medische zorg in verzorgingshuizen "nieuwe stijl", kunnen op basis van dit onderzoek niet gedaan worden. In het verlengde van de hier gepresenteerde resultaten zou echter een scenario van "gedeelde medische zorg" verdedigbaar zijn.

Gewezen wordt op het belang dat in de nabije toekomst gehecht dient te worden aan het realiseren van een betere onderlinge samenwerking tussen huisarts en verpleeghuisarts. De geschetste veranderingen in de ouderenzorg, waarbij de verpleeghuiszorg meer zal transmuraliseren en de huisartsgeneeskunde een partièle verschuiving van "cure" naar "care" zal doormaken, zijn hiervoor immers voldoende aanleiding. Het is duidelijk dat daarvoor voorwaarden geschapen en knelpunten opgelost moeten worden. Bijvoorbeeld kennisvergroting met betrekking tot elkaars werk en samen bijscholen; én ook concreet overleggen en samen optrekken in de zorg voor patiènten, daar waar dit geboden is.

Tot slot wordt nog gewezen op het belang van het verrichten van meer longitudinaal patiëntgebonden wetenschappelijk onderzock om na te gaan of een nauwere medische samenwerking en een betere continuĭteit van medische zorg ook inderdaad leiden tot een betere medische zorg voor de patiënten zelf. Dergelijk onderzoek kan bovendien extra aanknopingspunten opleveren over hoe de samenwerking tussen huisarts en verpleeghuisarts nader vorm gegeven kan én moet worden.

\section{Deel 4: Beschouwing en samenvatting}

In dit deel passeren de belangrijkste resultaten nog eens in grote lijnen de revue. Methodologische kanttekeningen worden besproken en aanbevelingen voor verder wetenschappelijk onderzoek en onderwijs worden gegeven. De samenwerking tussen huisarts en verpleeghuisarts wordt voorts nog in een breder perspectief geplaarst door aandacht te besteden aan een aantal aspecten, die buiten de directe context van de eigen onderzoeksactiviteiten liggen. Het betreft hier zaken zoals de zorgnetwerkvorming, de beroepsontwikkeling/professionalisering van de huisarts en de verplecghuisarts, en sociologische aspecten, samenhangend met het belang van samenwerking. 
SUMMARY 
This thesis is divided into 4 parts entitled: (part 1) General introduction; (part 2) From institutional care to outreaching care; (part 3) Cooperation between nursing home physician (NHP) and general practitioner (GP); (part 4) Discussion and summary. An addendum entitled 'Nursing home medicine in development' completes the thesis.

\section{Part 1. General introduction}

The concept of outreaching nursing home care is introduced and positioned within the context of present transmural care. Transmural care is a new concept in Dutch health care that was introduced in the beginning of the 1990's, and has been a rapidly growing field since then. The term refers to care given "outside the walls" of the existing system.

In the introduction also an outline of the thesis is presented.

Three major questions in nursing home (medicine) research lie at the bottom of the research-activities of this thesis:

1. Which groups of patients need institutional, ambulatory and outreaching nursing home care?

2. What are the effects of the different forms of nursing home care on the patients that receive it?

3. How is the cooperation between disciplines inside and outside the nursing home?

\section{Part 2. From institutional care to outreaching care}

164 The increasing need for professional care to the growing elderly population, cannot be met due to capacity problems in the institutional health care sector. Therefore, in order to be able to reach more disabled people, complicated and expensive health care facilities (admission to specialized centres) have to be substituted by accentuating home care. Improvement of home care facilities will also meet the wish of many elderly to stay as long as possible in their own homes or in old people's homes. Nursing homes try to adapt to these developments by providing outreaching care. The various possibilities for so called ambulatory (=semimural) and outreaching (=extramural) nursing home care are presented and discussed in this section.

In paragraph 2.2 a case study entitled 'Admission to a nursing home: need or virtue?' illustrates that nursing homes nowadays take care of much more than the traditional long-term institutional care. Besides traditional chronic and terminal care of patients, parients nowadays can be admitted for rehabilitation, crisis care, observation and diagnosis, and highly specialized care such as ventilation and coma care. Furthermore by consultation, by providing day-care and also by being involved in substitute care projects, nursing homes can contribute in postponing the ultimate admission of patients to institutional care.

Paragraph 2.3 gives an overview of the current nursing home facilities to provide outreaching care. Development and embedding of these new functions need solid scientific evidence. This however requires for instance the development of a specific and integrated patient monitoring system, for assessment and followup of the patient throughout the whole health care system. 
In paragraph 2.4 an inventory is made of 5 substiture care projects in old people's homes, performed by the nursing home 'de Riethorst' in Geertruidenberg, The Netherlands. Data were gathered by semi-structured interviews and inquiries. It was found that the general goal of substitution of nursing home care for outdoor parients is to provide complementary outreaching nursing home services, by which real nursing home admittance can be postponed or avoided. In fact, in many cases substitution care appeared to avoid nursing home admittance. In 1991-1993 there were 144 participants in these projects, from which only 11 at last were admitted to the nursing home. It was concluded however that in the near future the quality of these outreaching nursing home projects has to be improved, especially on aspects as continuity and methodology of care and with respect to the multidisciplinary approach. At last a structural solution for the complicated and uncertain financial support of these projects was urged.

Paragraph 2.5 describes the characteristics of nursing home day-care patients in the Netherlands in 1995 at first admission and at discharge. Data were derived from the National Nursing Home Registration System (SIVIS), in which in 1995 over $85 \%$ of Dutch nursing homes participated. Newly admitted day-care patients were characterized by high age ( $89 \%$ older than 65 years), a distribution with (only!) $9 \%$ more women than men and a morbidity pattern of chronic somatic (cerebrovascular disease $45 \%$ ) and psychogeriatric (dementia $80 \%$ ) disorders. This morbidity pattern was associated with a considerable degree of disability, in particular regarding the activities of daily living and mobility. Most patients $(78 \%)$ were admitted directly from their home. The average length of stay from admittance to discharge, for both somatic and psychogeriatric day-care patients was nine months. For about $10 \%$ of the somatic patients and $40 \%$ of the psychogeriatric ones ambulatory day-care resulted in (subsequent) admission to the nursing home itself. In the last decade nursing home day-care capacity has increased rapidly and parallel to this also the numbers of day-care patients. The average level of disability and the average period of treatment of nursing home day-care patients however has remained approximately the same in this period.

\section{Part 3. Cooperation between nursing home physician (NHP) and general practitioner (GP)} The proces of transmural care requires optimal cooperation between nursing home caregivers and caregivers outside the institution. This section specifically addresses the relationship between NHP and GP. Concerted action is needed for exchanging mutual knowledge and insight in specific patient problems and also to facilitate succesful interdisciplinar cooperation.

In paragraph 3.2 a review of literature is presented about the current relationship between NHP and GP in The Netherlands. The relationship between both disciplines is described from a historical perspective. Potential bottlenecks in the cooperation are presented and some models of cooperation are described.

In paragraph 3.3 an inventory was made on actual contacts, in 1996, between NHP's and GP's in the care region of the Geertruidenberg nursing home 'de Riethorst'. Registration of all contacts $(n=363)$ between the NHP's and the GP's, on newly admitted patients in the nursing home, in nursing home day care, in 
nursing home substitution care and with respect to consultation and other matters, was carried out. The registration on a standard form was done by the NHP's. The results indicate that the contacts between NHP's and GP's occurred. mainly unidirectionally from NHP to GP (91\%). In about $2 / 3$ of the cases the reasons for contact were associated with patient transitions. With regard to future developments in the health care services it was concluded that further investigations are necessary to gather more detailed information on the actual level of cooperation between the NHP and the GP and on the conditions that are required to increase this level of cooperation.

Therefore in paragraph 3.4 a national survey is presented on the intensity of cooperation between NHP's and GP's. In 1998 a short questionnaire was sent to the heads of the medical departments of all combined nursing homes in the Netherlands $(n=220)$. Combined nursing homes were chosen to be able to exclude potential differences between different categories of nursing homes (only psychogeriatric, only somatic, or both, - which is combined). The response in this. study was very high (98\%). The results showed that most nursing homes nowadays indeed provide various forms of outreaching care. In agreement with the findings described in paragraph 3.3, it was found out that the contactintensity berween NHP's and GP's in the context of either nursing home daycare, nursing home consultative care or nursing home substitute care still is low. The intensity of contact in projects of substitute care is positively influenced by solid agreements between both parties with regard to cooperation, by actually 166 working together for patients and by financial stimuli for GP's. Statistical analysis was performed to distinguish nursing homes with limited cooperation with GP's (group X) from those with close cooperation (group $\mathrm{Y}$ ), in order to identify predictors of cooperation intensity. The cooperation was more intense in rural areas and when nursing home physicians were involved who have a lower clinical workload, which will allow them to spend more time for outreaching activities including cooperation with others.

Subsequently a more detailed inquiry was performed among GP's and NHP's in order to relate mutual cooperation to continuity of medical care (paragraph 3.5). Twenty nursing homes were randomly chosen from respectively group $\mathrm{X}$ and group Y. Questionnaires were sent to all NHP's of these 40 institutions ( $n=137$ ) and to about 20 GP's in each care region of these 40 nursing homes $(n=780)$. The response was $31.9 \%$ among GP's and $68.6 \%$ among NHP's.

The results showed that a higher contact-intensity between NHP's and GP's leads to a situation, in which the medical activities with regard to patients are better geared to one another and thus lead to an intensified cooperation and a better continuity of medical care.

Other factors that were identified to improve mutual cooperation are:

- the importance being attached to an optimal cooperation by both disciplines;

- the conviction by the GP's of the additional value of supporting nursing home care facilities and NHP's in patient care;

- the knowledge of GP's and NHP's about each other's expertise;

- the fact that GP's and NHP's want to spend rime in working together:

- the easy accessibility by phone of GP's; 
- the waiting list issue in nursing homes, that requires solutions for patients to tide over the period until admission.

NHP's indicate that GP's are often not aware of both the possibilities of the NHP's-discipline and the nursing homes. Moreover GP's agree that NHP's should be taken in consult more often. These points of view link up with the proposed growth model for cooperation agreed by the Dutch Sssociation of Nursing Home Physicians (NVVA) and the Dutch Association of General Practitioners (LHV).

Nowadays specific attention is also paid to the medical care for residents of old people's homes. This problem however is only briefly discussed in paragraph 3.5 . Nevertheless in line with the results of the present study a scenario of shared medical care would seem to be advisable.

Finally, it is concluded that further longitudinal studies are indicated to investigate if a closer cooperation between NHP's and GP's and a better continuity of medical care indeed result in improved patient care.

\section{Part 4. Discussion and summary}

In the last part of the thesis, the most important results from the studies that were performed on the cooperation between general practitioner and nursing home physician are summarized.

Furthermore the cooperation between NHP and GP is placed in a broader perspective by paying attention to some important aspects, which lie beyond the horizon of the studies presented in this thesis. 


\section{DANKWOORD}


Aan de totstandkoming van dit proefschrift hebben velen direct of indirect bijgedragen.

Ferd Sturmans was, als een van de twee promotoren, de initiator van het proces dat geleid heeft tot de voltooiing van dit proefschrift. Hij bracht mede ordening aan in de "losse" wetenschappelijke activiteiten, die aan de meer structurele vooraf gingen. Hij organiseerde de contacten met de capaciteitsgroepen Huisartsgeneeskunde en Medische Sociologie van de Maastrichte Universiteit, waarna er een heuse begeleidingscommissie kwam, die de verdere onderzoeksactiviteiten structureel ging bewaken. Ook stond hij aan de basis van de contacten die gelegd werden met het NIVEL, waardoor het uiteindelijk mogelijk werd om op kwalitatief verantwoorde wijze de enquête-onderzoeken uit te voeren. Ferd, ik ben je hiervoor veel dank verschuldigd, evenals voor de kritische wijze waarop je steeds de onderdelen van het manuscript beoordeelde; daarnaast ook voor de gastvrijheid biij jou thuis.

Harry Crebolder heeft zich als tweede promotor eveneens als een vader over het onderzoek gebogen. Hij volgde het proces kritisch, bewaakte de rode draad en stond altijd klaar voor nadere hulp en advies. Het is ook de verdienste van Harry dat hij mij, een externe promovendus, door de Maastrichtse onderzoekscultuur en regelgeving heeft geleid. Harry, ik heb veel geleerd van de strenge, maar positieve wijze waarop jij steeds mijn teksten beoordeelde. Ik bedank je voor het in mi grestelde vertronwer en voor de gasturjiheid zowel hji, inu an de vakgrǫ̧ als bij jou thuis.

Jos Diederiks, co-promotor, had een duidelijke inhoudelijke inbreng in de vergaderingen van de begeleidingscommissie en in de bijeenkomsten bij het NIVEL in Utrecht. Hij leverde ook een belangrijke bijdrage aan de realisering van het totale manuscript.

Raymond Koopmans, co-promotor, had eveneens een inspirerende inhoudelijke inbreng in de bijeenkomsten van de begeleidingscommissie. Daarnaast voorzag hij op accurate wijze diverse onderdelen van het manuscript van commentaar. Ik bewaar goede herinneringen aan de energieke discussies die ik met hem, in Nijmegen, over de inhoud van het proefschrift heb mogen voeren. Raymond, ik hoop dat het je zal lukken om in en vanuit Nijmegen enkele structurele onderzoekslijnen in de verpleeghuisgeneeskunde op te zetten.

Anke de Veer, van het NIVEL in Utrecht, dank ik voor de geweldige inhoudelijke en organisatorische ondersteuning bij het verrichten van de enquête-onderzoeken onder huisartsen en verpleeghuisartsen. Anke, jij hebt er, als co-auteur van een aantal artikelen, bovendien toe bijgedragen dat we een en ander in een relatief kort tijdsbestek hebben kunnen afwerken.

Ada Kerkstra en Peter Groenewegen van het NIVEL droegen bij aan de leerzame bijeenkomster die we in Utrecht over het onderzoek gehouden hebben. Ze beoordeelden eveneens verschillende manuscriptonderdelen.

Woorden van dank en respect zijn verder op hun plaats voor alle patiënten, medewerkers, instellingen, huisartsen, verpleeghuisartsen. en anderen die in de onderscheiden, onderzoeksactiviteiten hebben geparticipeerd.

De LHV en de NVVA toonden bereidwillige medewerking om, bij respectievelijk huisartsen en verplecghuisartsen in het land, de participatie aan de enquêteonderzoeken aan te bevelen.

Miel Ribbe, Jan Stoop, Margreet te Wierik, Nicole Theunissen, Vincent Borst, 
Maria Sinnema, Dinnus Frijters, Harry Rila, Nynke van de Meij, Johan Mackenbach en Dominique Berendschot-de Lange dank ik voor hun rol bij de realisering van verschillende onderzoeksonderdelen of voor hun bijdrage als co-auteur.

De Raad van Toezicht van de Riethorst dank ik voor de geboden mogelijkheden om in en vanuit de stichting wetenschappelijke activiteiten te ontplooien. Frank Staal, collega-directeur in de Riethorst, dank ik voor zijn betrokkenheid bij het wel en wee van het onderzock, voor zijn voortdurend luisterend oor en voor onze al jaren durende vriendschap. De leden van het managementteam, Ank van Ast, Jan Swanen, Yvonne den Exter en Inge van Dongen toonden steeds belangstelling voor het onderzock.

De leden van ons artsenteam, Evelyn Klinkert, Maria Sinnema, Vincent Borst en Gé van Gorp en ook de VAIO's participeerden in enkele onderzoeksactiviteiten en hadden ook steeds een luisterend oor en de bereidheid tot meedenken.

Alle overige medewerkers van de Riethorst, zowel van de verschillende afdelingen en diensten in het verpleeghuis alsook van de verzorgingshuizen, dank ik voor de open sfeer die ze weten te creëren, waardoor er ruimte ontstaat om innovatieve en ook wetenschappelijke activiteiten te ontwikkelen.

Brigitte Timmermans bood secretariele ondersteuning bij de allereerste artikelen van mijn hand. Cecilia Verhaar dank ik voor de geweldige ondersteuning die ze geboden heeft in vrijwel het hele traject van dit proefschrift. Cecilia, als secretaresse was je tot voor een jaar nauw betrokken bij de totstandkoming van de meeste onderdelen. Daarbij ging het niet alleen om de administratieve ondersteuning. Je toonde ook veel belangstelling in het onderzoek en vormde voor mij een prima tiiclaatklep, als zaken eens niet liepen zoals ik dat wilde. Een jaar geleden heb je een andere baan aanvaard, die je meer mogelijkheden biedt om ook je expressieve kwaliteiten op het vlak van de beeldende vorming nader te ontwikkelen. Ik ben blij dat je desalniettemin bereid bent geweest om ook nadien nog vele uren te besteden aan de daadwerkelijke vormgeving van dit proefschrift. Je hebt er een prachtig boek van gemaakt.

Inge Hartman dank ik, als waardige en enthousiaste opvolgster van Cecilia, voor haar administratieve ondersteuning bij de paragrafen over de twee enquêteonderzoeken.

Peter Nuyten ontwierp de omslag, die voorin nader verklaard wordt.

De secretariaten yan de capaciteitsgroepen Huisartsgeneeskunde en Medische Sociologie van de Universiteit Maastricht zorgden steeds voor een gastvrije ontvangst in Maastricht.

Mijn ouders wil ik bedanken voor de mogelijkheid die ze me hebben geboden om geneeskunde te studeren. Pa, bedankt dat je het proefschrift nog eens hebt bekeken op tekstuele onjuistheden. Ma, jij was steeds bereid om acuut als oppas in te vallen in ons drukke gezin, als dit nodig was.

Jan en Annemie, als gepromoveerde broer en gepromoveerde zus zijn jullie beiden voor mij een voorbeeld en stimulans geweest. Annemie, jij was ook betrokken bij de verwerking van de data van een van de artikelen en zeer behulpzaam bij hẹ schrijuven vạn de Engelse sạmenvațing.

Dan tot slot, maar niet in de laatste plaats, Maria en de kinderen.

Maria, ik ben jou waarschijnlijk de meeste dank verschuldigd. Jij hebt mij veel ruimte gegeven om de activiteiten in het kader van dit proefschrift, die grotendeels in mijn vrije tijd hebben plaatsgevonden, te kunnen verrichten. Tot op de 
dag van vandaag heb je steeds begrip opgebracht voor de schaarse tijd die ik aan het gezin kon geven. Want ook de directietaken en de nevenfuncties snoepen hiervan veel tijd af. Een en ander hangt zeker samen met het feit dat je ook zelf al vele jaren parttime als verpleeghuisarts in de Riethorst werkzaam bent en dus precies weet waarmee ik bezig ben. Daarbij genieten we samen volop van onze kinderen Laurens, Rutger, Floris, Myrthe en Emma, die elke dag bijdragen aan het feit dat ons gezin zo'n dynamisch geheel geworden is. In Nelly hebben we dan ook nog eens een prima en trouwe oppas.

Laurens, Rutger en Floris wil ik nog even apart bedanken voor allerlei hand- en spandiensten die ze bij het afwerken van dit proefschrift hebben verricht en die ze ook thuis regelmatig verrichten om hun moeder te helpen, als ik er weer eens niet ben.

Maria, ik ben trots op én blij met jou en de kinderen! 
CURRICULUM VITAE 
Jos Schols werd op 30 november 1957 geboren te Valkenburg-Houthem. In 1976 behaalde hij zijn gymnasium-B diploma aan het Rythovius College te Eersel $(\mathrm{NBr})$. Na eenmalige uitloting voor de studie geneeskunde, voltooide hij in 1977 de propaedeuse Farmacie aan de Rijksuniversiteit Utrecht, waarna hij in september van dat jaar startte met de studie geneeskunde aan de Rijksuniversiteit Limburg, te Maastricht.

Tijdens deze studie was hij, van 1979-1980 studentlid van de universiteitsraad en de academische raad. Daarnaast was hij van 1980-1983 studentassistent bij de Capaciteitsgroep Fysiologie.

In 1983 behaalde hij zijn artsdiploma.

In de wachttijdperiode tot aan de huisartsopleiding was hij van 1983-1985, in het kader van het project WO-HBO van de Maastrichtse universiteit, vanuit de Capaciteitsgroep Fysiologie partime gedetacheerd ats docent bij de Fysiotherapieopleiding in Heerlen en de Hogere Laboratoriumschool te Sittard. Tevens verrichue hij werkzaamheden bij de Capaciteitsgroep Fysiologie zelf en was hij werkzaam als assistent-huisarts.

Van 1985-1986 volgde hij de buisartsopleiding te Maastricht. Het praktijkgedeelte van deze opleiding vond plaats bij huisartsopleider Fred Willemsen te Hoensbroek. In 1986 werd hij ingeschreven in het huisartsenregister.

In 1987 werd hij aangesteld als verpleeghuisarts en Hoofd Medische/Paramedische Dienst in Streekverpleeghuis St. Agnes (inmiddels, na enkele fusies, Stichting de Riethorst) te Geertruidenberg (NBr). Sinds 1991 is hij in dezelfde stichting werkzaam als directeur patiëntenzorg.

174 In 1991 werd hij ingeschreven in het register voor verpleeghuisartsen.

Van 1992 tot 1998 was hij, in her kader van de vervolgopleiding tor verpleeghuisarts erkend als verpleeghuisartsopleider en vanaf eind 1998 is hij, naast zijn directietaken, éen dag per week werkzaam bij de Vakgroep Verpleeghuisgeneeskunde van de KU Nijmegen.

Naast activiteiten in de Nederlandse Vereniging van Verpleeghuisartsen (NVVA) vervult hij reeds geтuime tijd nog een aantal functies. De belangijiksie zijn:

- lid van de visitatieconumissie van de Huisarts- en Verpleeghuisarts Registratie Commissie (HVRC);

- lid van het College voor Huisartsgeneeskunde en Verpleeghuisgeneeskunde;

- lid van her varuit het Ministerie van VWS georganiseerde, gestructureerde overleg orgaandonatie (GOOD), als vervolg op her lidmaatschap van de Ministeriële Stuurgroep Uitvoering Wet Orgaandonatie;

- lid van de Programmaraad voor Onderwijs- en Onderzoeksbeleid van de Stichring tot bevordering van Wetenschappelijk Onderwijs en Onderzoek in de Gezondheidszorg (SWOOG/partner van de Katholieke Universiteit Brabant (KUB), Tilburg);

- lid van de redactie van het Tijdschrift voor Verpleeghuisgeneeskunde.

Jos is getrouwd met Maria Sinnema, die ook verpleeghuisarts is. Hij is vader van 5 kinderen: Laurens, Rutger, Floris, Myrthe en Emma. 



\section{VERPLEEGHUISGENEESKUNDE IN ONTWIKKELING}




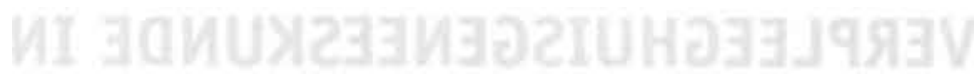

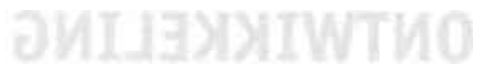

178 
Bij een specifiek medisch vakgebied hoort een eigen wetenschapsdomein. Voor de verdere ontwikkeling van de verplecghuisgeneeskunde is een goede wetenschappelijke onderbouwing van groot belang.

Het verpleeghuisgeneeskundig onderzoek dat tot op heden is verricht, is, evenals het gezondheidszorgonderzoek en het klinisch-epidemiologisch onderzoek in de verpleeghuiszorg, nog maar gefragmenteend en beperkt uitgevoend.

De verrichte studies zijn voor het grootste deel kleinschalig; ze maken geen deel uit van een onderzoeksprogramma en er is nog geen echte aansluiting bij aanverwante onderzoeksgebieden, universitair onderzoek of onderzoek van grotere onderzocksinstellingen.

Er is dan ook nog sprake van een gebrek aan wetenschappelijke kennis over het verloop van gezondheids- en andere problemen van patiënten, die een beroep doen op de verpleeghuiszorg in het algemeen en de verpleeghuisgeneeskunde in het bijzonder, alsmede over de inhoud, het proces en de effecten van de verplecghuis(geneeskundige)- zorg.

Het afgelopen decennium zijn weliswaar enige verpleeghuisgeneeskundige proefschriften verschenen, maar dat betekent nog niet dat er inmiddels structurele verpleeghuisgeneeskundige onderzoekslijnen zijn ontstaan. Deze proefschriften kunnen echter wel als exemplarisch beschouwd worden voor de verschillende aspecten waaraan in het verpleeghuisgeneeskundig onderzoek aandacht besteed zou kunnen worden.

Daarnaast is het zo dat nog slechts in een klein aantal verpleeghuizen een "wetenschappelijk klimaat" heerst en bovendien zijn er vooralsnog nauwelijks fondsen beschikbaar voor onderzoek.

Dat neemt nier weg dat er in de verpleeghuisgeneeskunde, in het kader van de verdere professionalisering van het vakgebied, een snel groeiende behoefte is aan richtlijnontwikkeling op het gebied van diagnostiek en behandeling. Het maken en onderbouwen van deze richtlijnen (veelal gebaseerd op evidence-based onderzoek) zal nog veel energie gaan kosten, als we hier mogen refereren aan de totstandkoming van standaarden in de huisartsgeneeskunde.' Desalniettemin zal deze ontwikkeling noodzakelijk zijn vooraleer, met het oog op het hedendaagse tijdsbeeld van de gezondheidszorg, echt overgegaan kan worden tot de ontwikkeling van transmurale richelijnen in de overgangsgebieden russen verpleeghuisgeneeskunde en aanverwante vakgebieden zoals huisartsgeneeskunde, geriatrie, psychiatrie en revalidatiegeneeskunde. ${ }^{5.6}$

De presentatie van kleinschalig onderzoek is belangrijk omdat dit niet alleen aan her vakgebied de unieke kans biedr om zich in bredere kring te presenteren maar ook de voedingsbodem kan vormen voor vraagstellingen, die kunnen leiden tot grotere toetsende onderzoeken.

In het addendum van dit proefschrift is, ter illustratie, een aantal eigen publikaties als voorbeeld opgenomen. 


\section{LITERATUUR}

1. Pijper NF de, Ribbe MW, Stoop JA. Verplecghuisgeneeskunde een nieuw medisch vakgebied. Ned Tijdschr Genceskd 1995; $139(36): 1820-3$.

2. Ribbe MW, Ooms ME, Wal G van der, Eijk JThM. Weterischappeliịk onderzock in de verplecghuisgenees:kunde: een voorwarde voor professionalisering. Ned Tijdschr Geneeskd 1995; 139(36): 1851-5.

3. Wendte II, Danse JAC. Verplecghuiszorg overzichtsatudie naar Nederlandse literatuur en onderzock sinds 1985. NCCZ-recks; Zorg, opvang en begeleiding van chronisch zieken. Zoetermeer: Nationale Commissie Chronisch Zicken, 1994.

4. Querido J. Waarover NHG-standaarden? Ze jar wikken door de NHG-adviesraad Standarden. Medisch Contact 1996: $51(11): 361-4$.

5. Zandvliet J). "Transmurale afspraken": cen nieuw begrip. Beleidsnota NHG. Medisch Contact 1996; 51 (17): $581-2$.

6. Katz R. Oplossing transmurale mysterie stapje naderbij, Hzh 1996; (1); $34-5$. 


\section{VERGEL.IJKING VAN HET EFFECT VAN HYYROCHLOORTHIAZIDE (HCTZ) VERSUS HCTZ/CAPTOPRIL; EEN ONDERZOEK BIJ OUDERE HYPERTENSIE PATIËNTEN}

centiventin injischint

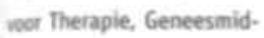
del en Onderzoek/Journal for Drugtherapy and Research TG0/JDR 1992;

$17: 231-5$

\section{J.M.G.A. Schols, H.J. Rila, A.J.M. Boermans, P.A. van Kampen, P.A. Leijten}

\section{SAMENVATTING}

Oudere hypertensie patiēnten worden vaak met diuretica behandeld. De vraag is, of toevoeging van een ACE-remmer kan leiden tot optimalisering van het metabole profiel van het diureticum, met behoud van effectiviteit en veiligheid van de behandeling.

In 15 Nederlandse huisartspraktijken werd een dubbelblind, gerandomiseerd, vergelijkend cross-over onderzoek verricht. De vaste combinatie van hydrochloorthiazide (HCTZ) 12,5 mg én captopril 25 mg werd vergeleken met HCTZ 25 mg als monotherapie.

In totaal werden 63 patiënten tussen 60 en 80 jaar oud opgenomen in het onderzoek. Beide therapieën gaven een effectieve bloeddrukdaling en werden door de patiënten goed verdragen. Tijdens de behandeling met HCTZ echter daalde de kalium- en steeg de serumcholesterolspiegel statistisch significant.

De combinatie van HCTZ en captopril, beide in lage dosering gegeven, lijkt bij de behandeling van de oudere hypertensie pariënt een veilig en effectief alrernatief voor de behandeling met een diureticum als monotherapie.

\section{SUMMARY}

Comparison of the effect of hydrochlorothiazide $v$ HCTZlcaptopril; in older hypertensive patients

Older hypertensive patients are usually treated with diurerics. The question arises whether the adding of an ACE inhibitor to diuretic treatment will optimize the metabolic profile of the diuretic, with maintenance of both the efficacy and safety of treatment.

A double blind, randomized, cross-over study was performed in 15 general practices in the Netherlands. The therapies compared were the fixed combination of hydrochlorothiazide (HCTZ) 12,5 mg and captopril $25 \mathrm{mg}$ OD versus monotherapy HCTZ $25 \mathrm{mg}$ OD.

A total of 63 patients aged between 60 and 80 years, were randomized into the study. Both therapies were effective in lowering bloodpressure and were well tolerated. During treatment with HCTZ, the serum potassium level decreased and serum cholesterol level increased significantly.

The combination of HCTZ and captopril both in low doses, appears to be an effective and safe alternative in the treatment of the older hypertensive patient.

\section{KERNPUNTEN}

- Bij oudere patiënten dient hypertensie, zeker wanneer ook andere risicofactoren aanwezig zijn, behandeld te worden.

- De oudere hypertensie patiënt wordt meestal met een, diureticum behandeld.

- Dit onderzoek toont aan dat het combineren van een lage dosis diureticum en een lage dosis ACE-remmer een therapie oplevert met een minstens even goede effectiviteit en minder negatieve invloeden op de metabole variabelen. 


\section{INLEIDING}

De prevalentie van hypertensie neemt toe met de leeftijd en is bij personen ouder dan 65 jaar in Nederland ongeveer 40\%.' De behandeling van hypertensie bij ouderen is zeker zinvol, gelet op de resultaten van grote interventie-onderzoeken, waarbij aangetoond is dat verlaging van een verhoogde bloeddruk, óók bij ouderen, tot een vermindering van de cardiovasculaire morbiditeit en mortaliteit leidt. Ongeveer tweederde van de hypertensiepatiënten van zestig jaar of ouder krijgt binnen 5 jaar decompensatio cordis, een myocard infarct, een CVA of een aneurysma dissecans, indien hun verhoogde bloeddruk niet behandeld wordt. ${ }^{25}$ De pathofysiologie van hypertensie bij de oudere patiënt is complex. Twee van elkaar te onderscheiden factoren spelen hierbij een rol: enerzijds de effecten van veroudering zelf op het hart/vaatstelsel en de nieren; anderzijds de effecten van langbestaande hoge bloeddruk op de zogenaamde doel (target) organen. Hypertensie mag bij ouderen in ieder geval niet beschouwd worden als een normale, fysiologische toestand. Dat geldt evenzeer voor de frequent voorkomende geïsolecrde systolische hypertensie.

Geconcludeerd mag worden dat een verhoogde bloeddruk bij een oudere patiënt met daarenboven een voldoende hoog risicoprofiel, behandeld dient te worden. Rest niet alleen de vraag welke antihypertensieve therapie bij oudere patiënten effecrief is, doch ook welke het meest veilig is.

In het algemeen worden oudere hypertensie patiënten met diuretica behandeld. Deze behandeling heef echter met name bij ouderen duidelijke beperkingen.

Negatieve effecten van diurecica op bepaalde metabole variabelen kunnen mogelijk de voordelen van verlaging van de bloeddruk tenier doen. Diuretica veroorzaken onder meer een activatie van her renine-angiotensine-aldosteron (RAA)systeem, waardoor een deel van de effecten op de metabole variabelen wordt verklaard. Angiotensine converting enzyme (ACE)-remmers zoals captopril, kunnen de vasculaire effecten van activatie van het RAA-systeem remmen. Uitgebreid onderzoek, hoofdzakelijk verricht bij patiënten van middelbare leeftijd, heeft aangetoond dat de combinatie van $50 \mathrm{mg}$ captopril en $25 \mathrm{mg}$ hydrochloorthiazide een oprimaal effect op de bloeddruk heeft met daarenboven weinig bijwerkingen, terwijl de effecten van hydrochloorthiazide op de metabole variabelen geneutraliseerd worden" ${ }^{*}$.

De vraag die dan gesteld kan worden is, of ook bij oudere patiënten de combinatie van een diureticum en een ACE-remmer een behandeling kan opleveren waarbij de metabole variabelen niet worden beïnvloed, terwijl de gewenste effectiviteit en veiligheid behouden blijven.

Bij oudere patiènten is een sterke bloeddrukdaling veelal ongewenst, terwijl ze bovendien vaak al gevoelig zijr voor lage doseringen antihypertensiva. Daarom is in het onderhavige onderzoek gekozen voor de combinatie van lage doseringen: HCTZ $12,5 \mathrm{mg} /$ captopril $25 \mathrm{mg}$ in vergelijking met HCTZ $25 \mathrm{mg}$ in monotherapie, eventueel eenmaal te verdubbelen gedurende het onderzoek. Naast het effect van beide medicatie regimes op de bloeddruk, werd hun effect onderzocht ten aanzien van de metabole variabelen: kalium, creatinine, totaal cholesterol, HDL-cholesterol en glucose. 


\section{METHODEN}

Onderzoekspopulatie

Patiènten van 60-80 jaar, met een in zittende houding gemeten diastolische bloeddruk (DBP) van 95-109 mm en een systolische bloeddruk (SBP) van 160-199 mmHg, gemeten na een placeboperiode van 4 weken, konden in dit onderzoek worden opgenomen. Indien de pariënt reeds medicamenteus werd behandeld voor hypertensie, werd deze therapie gestaakt. Als referentiebloeddruk werd de op één na hoogste DBP genomen van drie achtereenvolgende metingen, met de bijbehorende SBP.

Uitgesloten werden patiënten met secundaire hypertensie, hart-, lever- of nieraandoeningen, psychiatrische aandoeningen en diabetes mellitus.

Verder werden NSAID-gebruikers en patiënten met alcoholmisbruik niet in het onderzock opgenomen.

\section{Onderzoeksopzet}

Dit dubbelblind, gerandomiseerde vergelijkende cross-over onderzoek bestreek in totaal 28 weken. Vijftien huisartsen hebben actief aan het onderzock deelgenomen. Alle patiènten dienden mondeling toestemming te geven voor dẹlname aan het onderzoek, na eerst te zijn geïnformeerd over de rechten als deelnemer en het doel en de opzet van het onderzoek. Het feit dat toestemming voor deelname gegeven was, werd door de onderzoeker in het patiéntformulier bevestigd. Het onderzoek omvarte 3 perioden (A, B en C). Periode A was een enkelblinde washout periode van 4 weken, gedurende welke alle patiënten eenmaal daags met een placebotablet werden behandeld. De medicatie diende 's morgens direct nat het opstaan te worden ingenomen. Indien de patiënten vervolgens beantwoordden aan de in- en exclusiecriteria, werden zij voor periode B gerandomiseerd tor één van de behandelingsgroepen. Dit gebeurde door sequenticel toekennen van een nummer corresponderend met de reeds voor het onderzoek genummerde gerandomiseerde medicatie.

In periode B (totale duur 12 weken) werden de patiënten gedurende de cerste 4 weken behandeld met ofwel hydrochloorthiazide (HCTZ) 25 mg (basisdosering), ofwel de combinatie HCTZ 12,5 mg/captopril 25 mg (basisdosering). Patiënten van wie de DBP na wederom 4 weken hoger dan $90 \mathrm{~mm} \mathrm{Hg}$ was, werden voor de volgende 8 weken met de dubbele dosis behandeld. In periode C (12 weken) werden de pariënten behandeld met de omgekeerde therapie in opnieuw de basisdosis, waarna na opnieuw 4 weken de dosis zonodig kon worden verdubbeld. Alle pariënten bezochten na één week actieve medicatie in de perioden B en $\mathrm{C}$ de huisarts voor een routine controle op eventuele therapie-startproblemen.

Voor onderzoek van de metabole variabelen werd bloed afgenomen 2 weken vóör randomisatie en na 1 en 12 weken in de perioden B en $C$.

\section{RESULTATEN}

\section{Patiëntenpopulatie}

In totaal werden vijfentachtig (85) pariënten opgenomen in de placebofase van het onderzoek. Hiervan werden drieënzestig (63) patiënten gerandomiseerd in één van beide behandelgroepen. Tweeëntwintig (22) patiënten werden niet gerandomiseerd omdat zij na de placebofase niet bleken te voldoen aan de gestelde inen uitsluitingscriteria. 
Vijfenvijfrig (55) patiënten voltooiden het gehele onderzoek. Vóór randomisatie bestonden geen statistisch significante verschillen in pariëntkarakteristieken tussen de beide behandelingsgroepen (Tabel 1). Gedurende de placeboperiode (periode A) werden geen significante veranderingen van de bloeddruk gemeten.

\section{Bloeddruk}

De gemiddelde bloeddruk was $173,5 \pm 15,2 / 100,4 \pm 5,7 \mathrm{mmHg}$ tijdens placebobehandeling (einde periode $A$ ) en daalde significant $(\mathrm{P}<0.001)$ gedurende 12 weken behandeling met zowel captopril/HCTZ $(22,8 / 10,3 \mathrm{mmHg})$ als met HCTZ $(22,2 / 11,1 \mathrm{mmHg})(\mathrm{N}=56$; zie Tabel 2). Er was hier geen statistisch significant verschil tussen beide therapieèn aantoonbaar.

Het aantal patiënten bij wie dosisverdubbeling noodzakelijk was, was in beide groepen gelijk (55\%). Tevens bleek het aantal patiënten dat na 12 weken normotensief was (DBP $<90 \mathrm{mmHg}$ ) onder beide therapieèn niet significant verschillend; voor captopril/HCTZ 63\% (CI95: 57\%-69\%) en voor HCTZ 68\% (CI95: 62\%-75\%).

\begin{tabular}{|c|c|c|}
\hline & Captopril/HCTZ & $\mathrm{HCTZ}$ \\
\hline Geslacht (M/V) & $12 / 19$ & $12 / 20$ \\
\hline Leeftijd (jaar) & $67 \pm 6$ & $67 \pm 4$ \\
\hline Gewicht $(\mathrm{kg})$ & $81+14$ & $79 \pm 10$ \\
\hline Lengte $(\mathrm{cm})$ & $169 \pm 6$ & $168 \pm 9$ \\
\hline Quetelet inder $(\mathrm{kg} / \mathrm{m} 2)$ & $28.5 \pm 4,0$ & $28,3 \pm 4,0$ \\
\hline Behandeld/onbehandeld & $10 / 21$ & $6 / 26$ \\
\hline \multicolumn{3}{|l|}{ Bloeddruk (mmHg) } \\
\hline SBP & $174 \pm 19$ & $172 \pm 17$ \\
\hline DBP & $100 \pm 7$ & $101=4$ \\
\hline Kalium (mmol/l) & $4,3 \pm 0,4$ & $4,3 \pm 0,4$ \\
\hline Creatinine(mumol/1) & $86 \pm 18$ & $92 \pm 26$ \\
\hline Cholesterol (mmol//) & $6,2 \pm 1,1$ & $6,0 \pm 1,1$ \\
\hline HDL-chol (mmol/l) & $1,2 \pm 0.3$ & $1,1 \pm 0,3$ \\
\hline Glucose (mmol/l) & $6.2 \pm 1,8$ & $5,9 \pm 1,4$ \\
\hline
\end{tabular}

\begin{tabular}{lrrr} 
HCT2/CAPT & SBP $(\mathrm{mmHg})$ & DBP $(\mathrm{mmHg})$ & $\mathrm{N}$ \\
\hline Week 0 & $173,5 \pm 15,20$ & $100,4 \pm 5,70$ & 63 \\
Week 4 & $155,2 \pm 19,78$ & $90,6 \pm 8,06$ & 59. \\
Week 12 & $151,6 \pm 18,33$ & $90,0 \pm 8,12$ & \\
& & & $\mathrm{~N}$ \\
\hline HCT2 & SBP( $\mathrm{mmHg})$ & $\mathrm{DBP}(\mathrm{mmHg})$ & 63 \\
\hline Week 0 & $173,5 \pm 15,20$ & $100,4 \pm 5,70$. & 59 \\
Week 4 & $155,5 \pm 15,39$ & $91,0 \pm 7,65$ & 56 \\
Week 12 & $151,9 \pm 17,46$ & $89,4 \pm 7,97$ & \\
\end{tabular}

TABEL 1

Patiẻnt karakteristieken per rạndomișatiegroep voor opname in de eerste actieve behandelingsperiode (periode B).
TABEL 2

Bloeddrukken tijdens behandeling. 
TABEL 3

Effecten op de metabole variabelen.

\begin{tabular}{|c|c|c|c|c|}
\hline Variabele & $\begin{array}{l}\text { Na } \\
\text { placebo }\end{array}$ & $\begin{array}{l}\mathrm{Na} \\
\mathrm{CAPT} / \mathrm{ACT} Z\end{array}$ & $\mathrm{Na} \mathrm{HCT2}$ & $\begin{array}{l}\mathrm{ACAP} / \mathrm{HCT} \\
\mathrm{HCTZ} \text { (SE) }\end{array}$ \\
\hline Kaliu & $4,30 \neq 0,39$ & $4.21=0.38$ & $4,08+0,52^{\circ}$ & $0,10(0,07)$ \\
\hline Creatinine (umol/l) & $89,37 \pm 22,48$ & $90,57 \div 18,95$ & $91,52+27,73$ & $0,43(1,76)$ \\
\hline Cholesterol (mmol/). & $6,11=1,07$ & $6.22+1.16$ & $6,34+1,00 *$ & $0,12(0,14)$ \\
\hline HDL-cholesterol (mmol/ & $1,14=0,28$ & $1,13 \neq 0,31$ & $1,16+0,33$ & $0,03(0,03)$ \\
\hline Glucose (mmoly) & $6,04=1,58$ & $6,13 \neq 1,70$ & $6.24+2.15$ & $0.02(0.27)$ \\
\hline
\end{tabular}

- Verlaging ten opzichte van placebo $(P=0,018, N-50)$

$*$ Verhoging ten opzichte van placebo $(P=0,005, N=51)$

TABEL 4

Incidentie van Wachten bij specifieke navraag.

\begin{tabular}{lrrr} 
Klacht & Placebo & Capt/HCT & HCTZ \\
\hline Moeheid & $15 \times(24 \%)$ & $12 \times(22 \%)$ & $12 \times(22 \%)$ \\
Duizeligheid & $14 \times(22 \%)$ & $8 \times(15 \%)$ & $9 \times(16 \%)$ \\
Misselijkheid & $3 \times(5 \%)$ & $2 \times(4 \%)$ & $2 \times(4 \%)$ \\
Spierkrampen & $10 \times(16 \%)$ & $13 \times(26 \%)$ & $9 \times(16 \%)$ \\
Huiduitslag & $3 \times(5 \%)$ & $4 \times(7 \%)$ & $2 \times(4 \%)$ \\
Prikkelhoest & $8 \times(13 \%)$ & $12 \times(22 \%)$ & $7 \times(13 \%)$ \\
Smaakstoornissen & $1 \times(2 \%)$ & $2 \times(4 \%)$ & $1 \times(2 \%)$ \\
Slaapstoomissen & $15 \times(24 \%)$ & $11 \times(20 \%)$ & $10 \times(18 \%)$ \\
Impotentie & $2 \times(3 \%)$ & $2 \times(4 \%)$ & $2 \times(4 \%)$ \\
Licht gevoel in het hoofd & $9 \times(14 \%)$ & $9 \times(17 \%)$ & $11 \times(20 \%)$
\end{tabular}

(Geen significante verschillen tussen de behandelingsgroepen onderling of met de situatie voor randomisatie)

FIGUUR 1

Serumkaliumspiegels van 51 patiënten die

12 weken werden behandeld met $\mathrm{HCT}$. of $\mathrm{HCT} /$ captopril

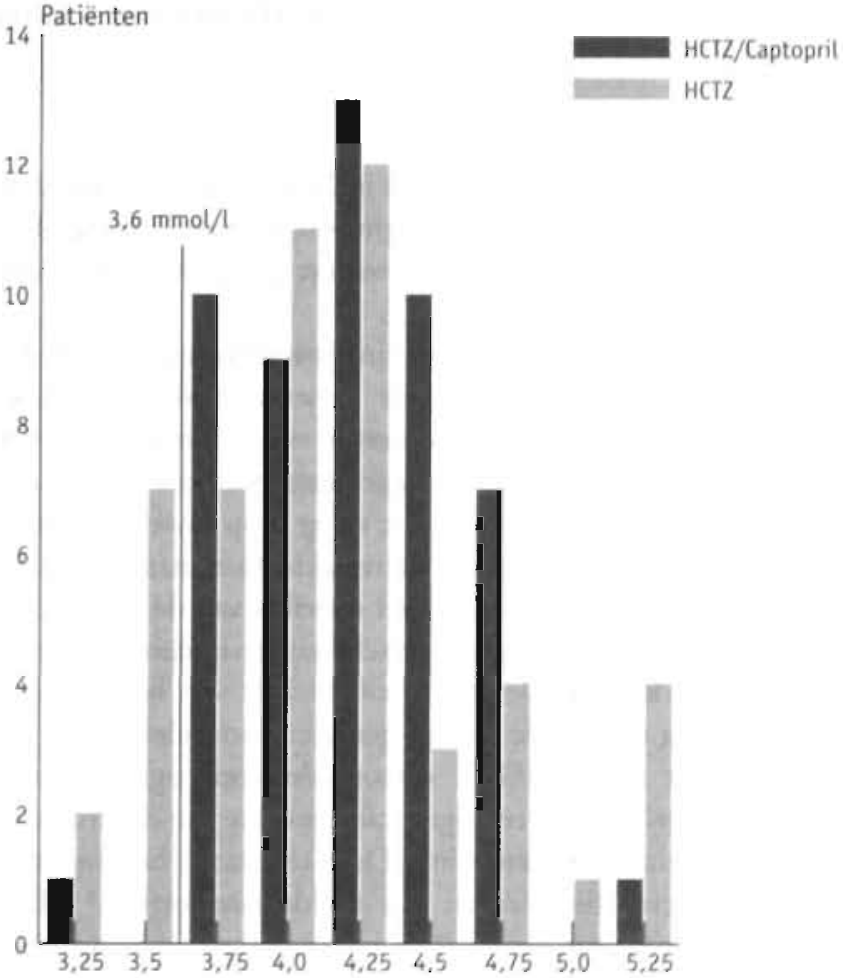




\section{Metabole variabelen}

$\mathrm{Na} 12$ weken behandeling met HCTZ vond een significante daling plaats van de serumkaliumspiegel ten opzichte van de: waarden gedurende placebotherapie (Tabel 3). De kaliumspiegel daalde bij 9 van de 51 patiënten (18\% van de met HCTZ behandelde patiënten) tot $3,6 \mathrm{mmol} / 1$ of lager, tegen één patiënt onder de captopril/HCTZ therapie (Figuur 1). De totaalcholesterol-spiegel was eveneens significant gestegen na 12: weken HCTZ therapie (Tabel 3). Er waren bij deze behandeling geen statistisch significante effecten meetbaar op de HDLcholesterol-, serumcreatinine- en glucosespiegels. Gedurende de behandeling met captopri//HCTZ werden ten aanzien van alle gemeten, metabole variabelen geen significante veranderingen waargenomen vergeleken met de placeboperiode.

\section{Vitvallers:}

Gedurende de behandeling met HCTZ vielen 5 patiënten uit; 2 patiënten vanwege duizeligheid, I patiënt vanwege een ileofemoraal trombose, 1 patiënt vanwege een arteriutis temporalis en 1 patiènt vanwege diabetes mellitus.

Gedurende de behandeling met captopril/HCTZ vielen 3 patiënten uit met klachten van buikpijn, trillerigheid en misselijkheid.

\section{Klachten}

Er werd geen melding gemaakt van hypotensieve reacties direct na het starten van beide therapieën. Tevens waren één week na de start van beide therapieën in periode $B$ en $C$ geen significante veranderingen aanroonbaar in de creatininespiegels.

Het aantal pariénten met secundaire therapieklachten was statistisch niet significant verschillend bij beide therapieèn (Tabel 4).

\section{BESCHOUWING}

Dit onderzock in 15 buisartsprakrijken in Nederland toont aan dat zowel HCTZ $(25 \mathrm{mg})$ als de combinaric HCTZ/captopril in lage dosering (12,5 $\mathrm{mg} / 25 \mathrm{mg})$ effectief is bij de behandeling van oudere patiënten met lichte tot matige hypertensie.

De combinatie HCTZ/captopril werd in dit onderzoek aanvankelijk toegepast in een dosering die de helfs is van de normaal aanbevolen dosering $(25 \mathrm{mg}$ HCTZ/50 mg captopril). De reden hiervan was, dat men bij de behandeling van hypertensie bij ouderen over her algemeen met een lagere dosis begint en bovendien streeft naar een therapie die veilig is op zowel korte als lange termijn. In dit onderzoek zip̧n van beide therapieën geen nadelige acute effecten op nierfunctie en bloeddruk gezien bij het instellen van de therapie.

Op langere iermijn werden geen verschillen gevonden in effectiviteit of incidentic van bijwerkingen. De gelijke effectiviteit van beide therapieën laat een goede vergelijking toe van de overige gemeten variabelen.

Behandeling met alleen HCTZ veroorzaakte een significante daling van de serumkaliumspiegel alsmede een significante stijging van de serumcholesterolspiegel vergeleken met placebobehandeling. Deze resultaten bevestigen eerdere onderzoeken met hypertensiepatiënten van middelbare leeftijd.: ${ }^{\prime \prime}$ Beide therapieën lijken weliswaar even succesvol bij de behandeling van hypertensie bij ouderen, 
doch de negatieve effecten van HCTZ op de serumcholesterol- en serumkaliumspiegel zijn voldoende belangrijk om in de keuze van de therapie te betrekken. Dit onderzoek toont verder an dat het combineren van twee antihypertensiva zeker niet hoeft te leiden tot een nadelige beïnvloeding van het bijwerkingenprofiel. De combinatie van een lage dosis diureticum en een lage dosis ACE-remmer (HCTZ/captopril), lijkt derhalve een veilig alternatief als middel van eerste keuze bij de oudere hypertensie patiënt.

\section{DANKBETUIGING}

Hierbij bedanken wij de onderzoek-stuurgroep voor de steun bij het schrijven van het protocol, de werving van onderzoekers en de raadgevingen gedurende het onderzoek, de verwerking van de onderzocksgegevens en de publikatie ervan: Prof. dr. W.H. Birkenhäger, Rotterdam; Prof. dr. A.J. Man in 't Veld, Rotterdam; Prof. dr. A.C. Arntzenius, Voorschoten; Prof. dr. A.J.M. Donker, Amsterdam; Prof. dr. D.W. Erkelens, Utrecht; Prof, dr. J. Lubsen, Nyon, Zwitserland en Prof. dr. J.W van Ree, Maastricht. 


\section{LITERATUUR}

1. Instituut voor Medische Diagnosticks peildarum 1986.

2. Kannel WB, Gordon T. Evaluation of cardiovascular risk factors in the elderly: The Framingham Study. Bull NY Acad Med 1978:54:573-91.

3. Shekelle RB, Osteld AM. Klawans HFJS. Hypertension and risk of stroke in elderly population. Stroke 1974:5:71-5.

4. Svarsudd K. Tibblun G. Mortality and morbidity during 13.5 yean follow-up in relation to blood pressure: The study of men born in 1913. Acta Med Scan 1979;205:483-92.

5. Amery A, Birkenhiger W. et al. Mortality and morbidity results from the European working party on high. blood pressure in the elderly trial. Lancet 1985;1:1349-54.

6. Kannel WB, Wolf PA. Syutolic blood pressure arteriol rigity, and risk of stroke: The Framingham Study. JAMA 1981:245:1225-9.

7. Weinberger MH. Diuretics and their side effects. Hypertension Suppl. II, vol II, no, 3, March 1988.

8. Stern D, Childs MJ, Lancernon S, Languilat JM. Determination of the optimal dosage regimen of captopril and hydrochlorothiaxide for the treatment of moderate arterial hypertension. Brit J of Clin Pharmacol 1987:23:65S.

9. Kayanakis JG. Bamlac L. Comparative study of once-daily administration $50 \mathrm{mg}$ captopril, hydrochlorothiazide $25 \mathrm{mg}$ and their combination in mild to moderate arterial hypertension. Brit J' of Clin Pharmacol 1986:62 (Suppl. 1):146-9.

10. Anderson H, Botra G. Efficacy of captopril and hydrochlorothiazide administered once a day, Postgrad Med J 1986:62 (Suppl. 1):146-9. 


\section{SLAAPPROBLEMEN EN SLAAPMIDDELENGEBRUIK IN EEN VERPLEEGHUIS EEN INVENTARISEREND ONDERZOEK}

Gepubliceerd in

Tijdschrift voor

Gerontologie en

Geriatrie 1991; 22:

$139-42$

\section{J.M.G.A. Schols}

\section{SAMENVATTING}

In april/mei 1989 werden het voorkomen van slaapproblemen en het gebruik van slaapmiddelen in een verpleeghuis geìnventariseerd, zowel bij in 1988 opgenomen patiënten bij opname als bij alle bewoners op peildatum. Uit de resultaten blijkt dat, in tegenstelling tot de heersende opvatting, opname in een verplecghuis niet hoeft te leiden tot een toename in het hypnotica- en neurolepticagebruik. Van de totale interne patiëntenpopulatie had ongeveer eenderde hardnekkige subjectieve slaapproblemen, waarvoor echter niet in alle gevallen behandeling noodzakelijk was. Opvallend was het grote aantal patiënten op de somatische reactiveringsafdeling met slaapklachten en medicamenteuze behandeling daarvoot. Ter verklaring wordt de communicatichypothese geponeerd: somatische (m.n. reactiverings)patiènten kunnen zelf vragen om medicatic, terwijl therapie bij psychogeriatrische patiènten niet zelden door de hulpverleners wordt geïnitieerd. Aandacht wordt gevestigd op een aantal veel voorkomende slaapverstorende prikkels, zoals het gehanteerde dagschema en nachtelijke verplegingsactiviteiten ten behoeve van kamergenoten, die eigenlijk een aanpassing van de organisatic van de verpleeghuiszorg vereisen.

\section{SUMMARY}

Sleeping problems and use of hypnotics in a nursing home

An inventory has been made on sleeping problems and the use of hypnotics in a nursing home. Contrary to general opinion, the results show that admission to a nursing home does not have to lead to an increase of hypnotics and neuroleptics used. One third of the total patient population revealed severe subjective sleeping problems, for which, however, a therapeutic intervention was not always necessary. In particular somaric revalidation patients showed high percentages of sleeping complaints and medical treatment. A communication hypothesis is presented as a possible explanation: somatic patients are able to ask for medication contrary to psychogeriatric patients, for whom the caregiving network often initiates therapeutic intervention. Attention is focussed on a few sleep disturbing stimuli that often occur in the setting of a nursing home. Prevention of these stimuli implicates changes in the nursing care organization. 


\section{INLEIDING}

Het is een bekend feit dat veel oude mensen klagen over hun slaap. Dit wordt bovendien bevestigd door empirisch onderzoek. In het algemeen wordt aangenomen dat chronische slaapklachten bij ongeveer $20 \%$ van de mensen van 65 jaar en. ouder voorkomen. Daarbij blijken vrouwen veel meer klachten over de slaap te hebben dan mannen. Ook het slaapmiddelengebruik stijgt met de leeftijd, zeker bij vrouwen. ${ }^{\text {'S }}$

Bewoners van verzorgingshuizen onderscheiden zich van zelfstandig wonende bejaarden door een aanmerkelijk hoger hypnoticagebruik." Betrouwbare gebruiksstatistieken over hypnotica in Nederlandse zieken- en verpleeghuizen ontbreken. Dit heeft ons ertoe aangezet om in het eigen verpleeghuis hiernaar een inventariserend onderzoek te verrichten. ${ }^{6}$

Het Streekverpleeghuis in Geertruidenberg is een gecombineerd verpleeghuis dat plaats biedt aan 105 somatische en 60 psychogeriatrische patiënten. In het verpleeghuis waren ten tijde van het onderzoek twee artsen werkzaam. Ten aanzien van de diagnostiek en de behandeling van slaapklachten wordt een samenhangend beleid gevoerd."

\section{METHODIEK}

Het uitgevoerde onderzoek bestond uit twee onderdelen:

\section{Onderdeel I:}

Alle in 1988 opgenemen patiënten werden gescreend enerzijds op hypnoticagebruik vanwege slaapklachten en anderzijds op gebruik van neuroleptica, met als primaire indicatie 'nachielijke onrust' (= slapeloosheid + desoriëntatie). Retrospectief werd gekeken naar het gebruik van slaapmedicatie op het moment van opname. En er werd ook gepoogd een indruk te verkrijgen over het gebruik tijdens opname, door de voorgeschreven slaapmedicatie bij deze groep patiënten opnieuw te registreren in de laatste week van april 1989.

\section{Onderdeel II:}

In de laatste week van april en de eerste week van mei 1989 werd eveneens een 'peiling' verricht onder het totale patiëntenbestand dat toen aanwezig was in onze kliniek. Daarbij werden geregistreerd:

- het voorkomen van hardnekkige, dat wil zeggen bijna dagelijkse, subjectieve (door de patiënt aangegeven) slaapstoornissen;

- het voorkomen van hardnekkige objectieve (door het verplegend personeel aangegeven) slaapproblemen;

- de aangegeven oorzaken voor gerapporteerde slaapstoornissen;

- het percentage van patiënten met klachten over de slaap of nachtelijke onrust, dat daarvoor (wel of niet) medicamenteus behandeld werd.

De patiënten werden voor zover mogelijk persoonlijk benaderd (interview/ subjectief beeld). Ter controle werden eveneens de afdelingshoofden ondervraagd (objectief beeld). Overige bronnen waren de medische en verpleegkundige statussen èn de op de afdelingen aanwezige medicijnverdeelklappers. 


\section{RESULTATEN}

\section{Resultaten I: slaapmiddelengebruik bij in 1988 opgenomen patiënten}

In 1988 werden 81 patiènten opgenomen: 47 vrouwen en 34 mannen. De gemiddelde leeftijd bedroeg 76 jaar $(4<65)$. Zesenzestig patiënten werden opgenomen op een somatische, 15 op een psychogeriatrische afdeling (tabel I). De hoofddiagnoseprofielen van zowel opgenomen somatische als psychogeriatrische patiënten pasten zonder meer binnen de frequentieverdeling, zoals aangegeven in de landelijke SIVIS-rapportage.' Dit gold ook voor de plaats van herkomst. Veruit de grootste groep $(n=44)$ bleek afkomstig uit het ziekenhuis. Ruim een kwart kwam van thuis $(\mathrm{n}=24)$. Van de opgenomen patiènten gebruikten er 19 bij opname cen hypnoticum (tabel I). Het hypnoticagebruik was daarbij relatief iets hoger bij mannen dan bij vrouwen. Er was bij opname bovendien sprake van duidelijk meer hypnoticagebruik bij somatische dan bij psychogeriatrische patiënten, met ook hier weer een relatief overwicht van de mannen. Als hypnoricum werd meestal een benzodiazepine met relatief korte werkingsduur gebruikt. Van de 81 opgenomen patiënten gebruikten er 6 bij opname een neurolepticum vanwege nachtelijke onrust. De psychogeriatrische patiēntencategorie vertoonde hier een relatief overwicht (tabel I). Er bestond daarbij géén overlap met de hypnoticagebruikers.

In de laatste week van april 1989 verbleven nog 52 van de in 1988 opgenomen patiënten in de kliniek $\{20$ patiënten waren overleden ( 3 gebruikten een hypnoticum vanaf opname rot overlijden); 9 waren er ontslagen, waarvan 4 met een hypnoticum, zowel bij opname als bij ontslagł.

Van de overgebleven groep, mer een gemiddelde verblijfsduur van 9 maanden, gebruikten er nog 9 een hypnoricum en 2 een neurolepricum vanwege slaapproblemen. Her hypnoticagebruik was dus procentueel nog $17 \%$ in vergelijking tot de $23 \%$ bij opname. Het neurolepricagebruik nog $4 \%$ in vergelijking tot de $7 \%$ bij opname. Deze percentages bleken goed te passen binnen de vigerende behandelpercentages in de totale patiëntenpopulatie (Zie Resultaten II).

\section{Resultaten II: peiling april/mei 1989 onder totale patiëntenbestand}

In de laatste week van april en de eerste week van mei 1989 werden alle op dat moment in het verpleeghuis verblijvende patiënten eveneens gescreend ten aanzien van hun slaap en de eventuele medicatie hiervoor. Er verbleven 167 patiënten, waarvan 35 mannen en 132 vrouwen. De gemiddelde leefrijd bedroeg 82 jaar $(9<65)$. De gestelde hoofddiagnosen bleken representatief vergeleken met de landelijke SIVIS-registratie.? Tabel 2 toont dat circa 30\% subjectieve slaapproblemen aangaf. Er waren relatief iets meer klachten bij de mannen (37\% versus $28 \%$ bij de vrouwen). Duidelijk is ook het relatieve overwicht van somatische patiënten in de klachtengroep $(\mathrm{n}=38)$. Meer dan de helft van deze patiënten verbleef op de reactiveringsafdeling $(n=21)$.

Wat de aard van de slaapproblemen betrof, ging het, voor zover na te gaan, in gelijke mate om klachten over het inslapen als om het doorslapen. Behalve op de endogeen aanwezige oorzakelijke factoren werd door de patiënten gewezen op de negatieve invloed van een aantal exogene slaapverstorende prikkels, die frequent in het verpleeghuis optreden. Een frequentieverdeling is in tabel 3 aangegeven. Van de 50 patiënten met klachten werden er 32 behandeld. Dit betekent dat $19 \%$ van alle patiënten behandeld werd (tabel 2). Achtereenvolgens werden 


\begin{tabular}{llll}
$\begin{array}{l}\text { auntal opgenomen } \\
\text { potiënten } 1988(n=81)\end{array}$ & $\begin{array}{l}\text { afdeling } \\
(n=19)\end{array}$ & $\begin{array}{l}\text { neuroleptica } \\
(n=6)\end{array}$ \\
\hline $\begin{array}{l}\text { vrouwen (47) } \\
\text { somatiek (37) }\end{array}$ & 8 & 0 \\
psychogeriatrie (10) & 1 & 2 \\
mannen (34) & somatiek (29) & 10 & 3
\end{tabular}

TABEL 1

Hypnotica- en neurolepticagebruik vanwege slaapklachten biị patiènten opgenomen in 1988.

\begin{tabular}{|c|c|c|c|}
\hline $\begin{array}{l}\text { Aantal patiènten } \\
\text { ApriVmei } 1989(n-167)\end{array}$ & afdeling' & $\begin{array}{l}\text { subjectieve slaapklachten } \\
(n=50)\end{array}$ & $\begin{array}{l}\text { hynotica } \\
(n=32)\end{array}$ \\
\hline \multirow[b]{2}{*}{ vrouwen (132) } & somatiek (82) & 27 & 18 \\
\hline & psychogeriatrie (50) & 10 & 3 \\
\hline \multirow{2}{*}{ mannen (35) } & somatiek (23) & 11 & 9 \\
\hline & psychogeriatrie (12) & 2 & 2 \\
\hline
\end{tabular}

\section{TABEL 3}

ropportage

intrinsiek:

* problemen m.b.t. het lichamelijk welbevinden (w.o. mataise, pijn, jeuk, dyspnoe)

extrinsiek:

- het gehanteerde dagschema, vaak meer aangepast aan de verzorgings-/ verplegingsroutine dan aan de patiènten

- frequente onverwachte geluiden op de slaapkamers en op de gangen nachtelijke verplegingsactiviteiten ten behoeve van kamergenoten
TABEL 2

Subjectieve slaapproblemen (bijna dagetijks voorkomend) in het verpleeghuis.

\section{Aangegeven} slaapverstorende prikkels door groep patiènten met subjectieve slaapklachten $(n=50)$.

respectievelijk $31 \%$ van alle aanwezige mannelijke patiënten en het grootste deel van de mannen uit de klachtengroep behandeld (11 van de 13). Eveneens werden respectievelijk $16 \%$ van alle aanwezige vrouwelijke patiënten en iets meer dan de helft van de vrouwen uit de klachtengroep behandeld (21 van de 37). Op de somatische afdelingen werd $26 \%$ van alle daar aanwezige pariënten behandeld, waarvan een groot deel op de reactiveringsafdeling verbleef (18 van de 27). Op de psychogeriatrische afdelingen werd $8 \%$ van alle aanwezige patiènten behandeld met hypnotica $(\mathrm{n}=5)$. Meestal werden hypnotica met een korte werkingsduur voorgeschreven. De gemiddelde behandelduur bedroeg 10 maanden, doch hier was sprake van een grote spreiding. De satisfactie over de behandeling was over het algemeen goed.

Ten tijde van de peiling was objectief gerapporteerde nachtelijke onrust aanwezig 
bij 10 patiènten; dat wil zeggen bij $6 \%$ van de totaal aanwerige interne patièntengroep. Het betrof hier 7 psychogeriatrische en 3 somatische patiënten. Daarbij bestond er géén overlap met de subjectief klagende patiènten. Alle patiènten met nachrelijke onrust werden neuroleptisch behandeld, waarmee het neurolepricagebruik eveneens $6 \%$ bedroeg. De gemiddelde behandelduur was hier 5 maanden.

\section{DISCUSSIE}

Vooropgesteld dient te worden dat nadere analyse van de gevonden percentages mocilijk is, aangezien vergelijkbaar onderzoek in Nederland nauwelijks beschikbaar is. Een in 1986 uitgevoerd onderzoek bij alle in een bepaalde maand opgenomen patiënten in het Medisch Centrum Alkmaar toonde overigens onder opgenomen 60-plussers een hypnoticagebruik van $38 \%$ bij opname en $46 \%$ tijdens opname aan." Bovendien dient een voorbehoud gemaakt te worden aangezien het hier cijfers betreft van slechts één verplecghuis, al is de representativiteit van de onderzochte patiěnten als een gemiddelde verplecghuispopulatic evenwel gewaarborgd.

Bezien we de in 1988 opgenomen patiènten dan blijkt circa een kwart hiervan bij opname een hypnoticum te gebruiken in verband met slaapklachten. Dit hypnoticagebruik wordt bovendien met name teruggevonden bij somatische patiënten. Zeven procent van de in 1988 opgenomen groep gebruikte bij opname een neurolepticum voor nachtelijke onrust, waarbij de psychogeriatrische patiènten een relatief overwicht vertoonden.

Mogelijk dar beide verhoudingen tussen somatische en psychogeriatrische patiënten veroorzakt worden vanuit het communicatieaspect. Somatische patiënten kunnen in het algemeen duidelijker hun klachten, dus ook slapproblemen, verwoorden en zijn derhalve misschien beter in staat om te vragen om een therapeutische interventie. Therapie bij psychogeriatrische patiënten wordt daarentegen niet zelden geïnitieerd vanuit de verzorgende omgeving van de patiënt. Deze communicariehypothese verdient echter nader onderzoek. Voor het relatieve overwicht van de mannen wat betreft het hypnoticagebruik. kon in deze inventariserende studie géén verklaring gevonden worden.

$\mathrm{Na}$ een gemiddelde verblififsduur van negen maanden vertoonde de restgroep een hypnoticagebruik van $17 \%$ en een neurolepticagebruik van $4 \%$. Opname in een verpleeghuis hoeft dus in principe niet te leiden tot een fors additioneel hypnotica- en neurolepticagebruik in verband met slaapstoornissen, zoals overigens wel vaker beweerd wordt. Deze percentages sloten uitstekend aan bij de behandelpercentages in de totale patiëntenpopulatie.

De peiling onder het totale patiëntenbestand leverde eveneens interessante gegevens op. Zo bleken subjectieve slaapklachten bij een aanzienlijk aantal (30\%) voor te komen. Slaapproblemen werden met name aangegeven door somatische patiënten met een oververtegenwoordiging op de reactiveringsafdeling. Reactiveringspatiënten onderscheiden zich in een verpleeghuis in het algemeen door het beste prognostische profiel. Voor het iets grotere aantal mannen in de klachtengroep kon ook hier geen verklaring worden gevonden. De slaapstoornissen betroffen in gelijke mate zowel het inslapen als het doorslapen. Wat de causaliteit betreft, bleek duidelijk dat, naast endogeen aanwezige factoren, ook de zorgorganisatie en de architectuur van her verpleeghuis belangrijke slaapverstoorders zijn. Hieraan zou dan ook meer aandacht besteed moeten worden. Bij nieuw- 
bouw en renovatie zal bijvoorbeeld meer gestreefd moeten worden naar minder patiënten per kamer. Bovendien kan het simpelweg rustig benaderen van een patiënt's nachts al een grote uitkomst zijn.

Van de patiënten met subjectieve slaapklachten werd circa twee derde behandeld met hypnotica. Het betrof hier $19 \%$ van de totale patiëntenpopulatie. Meestal werd een hypnoticum met een korte werkingsduur gebruikt, hetgeen past binnen de heersende denkbeelden hierover."

Dit deel van het onderzoek leverde eveneens argumenten op voor de eerder genoemde communicatiehypothese. Zo bleek namelijk uit een nadere analyse dat op de reactiveringsafdeling een hoge behandelfrequentie bestond, mede veroorzaakt doordat alle daar behandelde patiënten zèlf daarom hadden gevraagd. Op $\mathrm{de}$ andere afdelingen was hiervoor nogal eens het afdelingshoofd als intermediair opgetreden.

Nachtelijke onrust bleek aanwezig bij $6 \%$ van de patiënten, waarbij uit de statussen bleek dat allen behandeld werden mede op verzoek van de afdelingsleiding. 


\section{LITERATUUR}

1. Mulder HC, Ruskamp FM. Enkele gegevens over het gebruik van rustgevende middelen en het voorkomen van slapeloosheid bij mensen van 65 jaar en ouder in de gemeente Groningen.

Ned Tijdschr Gerontol 1976; 7: 67-73.

2. Ormel J. Tijdschr Soc Geneeskunde 1975; 53: 494 .

3. Hoofdakker RH van den, Goetsch H. Slapeloosheid bij bejarden. Pharm Weekblad 1979; 114 1131.

4. Haaijer-Ruskamp FM, Stewart R. Wesseling H. Het geneesmiddelengebruik van ouderen in de huisartspraktijk. Groningen: Rijksuniversiteit, 1988.

5. Haxijer-Ruskamp FM, Dingemans, CAJ. Pychopharmacagebruik bij ouderen. Teveel (?) van het goede? The Practitioner 1988 5; 14: 1007-13.

6. Schols JMGA. Slaapproblemen in een verplecghuis, Gegevens van het Streekverplexghuis St. Agnes te Geertruidenberg, april/mei 1989. Gepresenteend op slapsymposium in Leeds (Engeland) op 20 mei 1989.

7. SIVIS jarhocken $1987 / 1988$ Utreche: SIG/Informatiecentrum voor de gezondheidszorg.

8. Steenhock. A. Slaapmiddelenenquète Med. Centr. Alkmaar. 1986.

9. Schols JMGA. Slaapproblemen bij de oudere mens. Geriarrie in de praktijk 1989 1: 10: 318-21. 


\section{SLAAPPROBLEMEN BIJ VERPLEEGHUISPATIËNTEN; DE EFFECTIVITEIT VAN ZOPICLON}

Gepubliceerd in

Tijdschrift voor

Therapie, Geneesmiddel

en Onderzoek/Joumal

for Drugtherapy and $P$

Research TGO/DDR

1993; 18: 222-6.

\section{J.M.G.A. Schols en N. van der Meij}

\section{SAMENVATTING}

In dit onderzoek zijn de resultaten beschreven van 246 somatische verpleeghuispatiënten die van een benzodiazepine-slaapmiddel overschakelden op zopiclon. Slaapparameters, fitheid na het ontwaken en dagelijks functioneren namen significant toe wanneer de patiènten op zopiclon-medicatie overgingen en deze verbeteringen bleven tijdens de 3 weken van het onderzoek gehandhaafd. Wanneer de slaapkwaliteit op zopiclon wordt vergeleken met die op het vorige benzodiazepine-hypnoticum vertoonde $57 \%$ van de patiènten een verbetering van één of meer punten van de slaapvragenlijst, terwijl er bij $36 \%$ geen verandering optrad en slechts bij $6 \%$ van een verslechtering sprake was.

Van de deelnemende verpleeghuisartsen beoordeelde $83 \%$ de effectiviteit van zopiclon als goed tot zeer goed. Het percentage bijwerkingen op zopiclon is lager dan wat er in eerdere onderzoeken met zopiclon in Nederland werd gerapporteerd. De bekendste bijwerking, bittere smaak, is karakteristiek voor zopiclon. De conclusie van dit onderzoek is dan ook dat bij oudere verpleeghuispatiènten met slaapproblemen, zopiclon een zowel effectief als veilig hypnoticum is en een goed alternatief voor de benzodiazepine-slaapmiddelen.

\section{SUMMARY}

Sleeping problems in nursing home patients; the efficacy of zopiclon

This study in 246 nursing home patients examined the effects of switching from. a bemzodiazepine to zopiclone. Chronic benzodiazepine users, living in a nursing home because of somatic disorders were included. Sleep parameters, subjective feelings on waking and daily functioning improved significantly when patients started on zopiclone and these improvements were maintained throughout the study period. Comparing sleep quality on zopiclone with that during the treatment period with the previous hypnotic, $57 \%$ of patients showed an improvement of one point or more on the 7-point scale of the questionnaire, whilst in $36 \%$ there was no change and in only $6 \%$ a worsening. $83 \%$ of the investigators rated the hypnotic efficacy of zopiclone as good to very good. Side effects are lower in frequency to that reported in previous dinical studies with zopiclone in The Netherlands. The most common side effect, bitter taste, is characteristic of this drug. In conclusion, this study suggests that for elderly insomniacs in nursing homes, zopiclone is an effective and safe hypnotic and a good alternative to benzodiazepine hypnotics.

\section{INLEIDING}

Slaapstoornissen vormen een veel voorkomend probleem bij ouderen. In het algemeen wordt aangenomen dat chronische slaapklachten bij ongeveer 20\% van de 65-plussers voorkomen. Daarbij hebben vrouwen veel meer klachten over de slaap dan mannen. De meest frequente klacht betreft het inslapen. Dan volgen klachten omtrent het doorslapen, respectievelijk het te vroeg wakker worden en combinaties hiervan. 23 
Ook het slaapmiddelengebruik stijgt met de leeftijd, zeker bij vrouwen. ${ }^{2.4}$ Kwantitatief gezien betreft dit vooral de prescriptie van benzodiazepinen. Het gebruik in de huisartsprakrijk van juist deze groep geneesmiddelen stijgt zeer sterk met de leeftijd.'

Slaapstoornissen vormen ook een niet te onderschatten probleem in verpleeghuizen. Dit kan in deze instituten soms tot een routinematig voorschrijven van hypnotica leiden.

Een zorgvuldig diagnostisch en therapeutisch beleid ten aanzien van slaapstoornissen in verpleeghuizen zou dan ook obligatoir dienen te zijn. ${ }^{6.7}$

Daar waar men bij ouderen met slaapklachten niet ontkomt aan een medicamenteuze interventie, is het belangrijk om rekening te houden met de veranderde fysiologie, de comorbiditeit en de veelal aanwezige co-medicatie. Ouderen zijn dientengevolge veel kwetsbaarder voor bijwerkingen. Ten aanzien van de hypnotica betekent dit met name de ongewenste sedatie overdag, met alle risico's vandien, alsmede de negatieve invloed op het cognitief functioneren. Extra voorzichtigheid geldt opnieuw voor de oudere verpleeghuispatiënt, bij wie vaak al sprake is van een algehele balansverstoring.

Als slaapstoornissen medicamenteus worden behandeld, blijken zowel huisarts, internist, psychiater alsook verpleeghuisarts meestal te kiezen voor een benzodiazepine."

Benzodiazepinen vertonen minder schadelijke bijwerkingen dan de hypnotica uit het verleden, zoals de barbituraten. Toch is het bepaald niet zo dat deze medicamenten achteloos kunnen worden voorgeschreven. Met name bij ouderen komen ongewenste neveneffecten, zoals spierzwakte, nachtelijke verwardheid, afname van het cognitief functioneren en verminderde prestaties overdag, relatief vaak voor. Onderzoek naar een ideaal geriatrisch hypnoticum blijft dan ook noodzakelijk. Sinds een aantal jaren is een niet-benzodiazepineslaapmiddel in de handel, behorend tot de groep van de cyclopyrrolonen, het zopiclon.

Diverse onderzoeken tonen aan dat dit middel bij ouderen met slaapklachten minstens even effectief is als de benzodiazepinen en zelfs leidt tot cen verbeterde slaaparchitectuur. ${ }^{9,0,11}$

Bovendien geeft zopiclon minder rest-effecten overdag ${ }^{12.13}$; het heeft geen effect op de ademhaling ${ }^{1615,1 \%}$, een geringere spierrelaxatie bij proefdieren ${ }^{1619}$ en vertoont een mogelijk lagere bijwerkingenincidentie dan benzodiazepinen." Het vormt hierdoor een aantrekkelijk alternatief voor de benzodiazepine-slaapmiddelen.

Het ligt derhalve voor de hand om de effectiviteit, het bijwerkingenprofiel en de satisfactiecomponent van zopiclon, ook te onderzoeken bij verpleeghuispatiënten. In dit artikel wordt het Gerimo-onderzoek beschreven, dat uitgevoerd werd bij 246 verpleeghuispatiènten met chronische slaapstoornissen, die na een omschakelperiode van één week zopiclon kregen voorgeschreven ter vervanging van hun benzodiazepine-slaapmiddel.

Het doel van het Gerimo-onderzoek, dat in 1990 in verschillende Nederlandse verpleeghuizen werd uitgevoerd, was het bestuderen van de effecten van zopiclon op de slaap en op het functioneren overdag en deze effecten te vergelijken met het voorafgaande benzodiazepine-slaapmiddel.

\section{OPZET VAN HET ONDERZOEK}

In het onderzoek werden verpleeghuispatiënten betrokken met chronische slaap- 
stoornissen, die vanwege een somatische aandoening lange tijd verpleegd werden. 246 Patiënten ( $68,6 \%$ vrouwelijk en $31,4 \%$ mannelijk) namen aan het onderzock deel. $\mathrm{Zij}$ hadden vanwege één of meer slaapstoornissen, tenminste in de 4 weken voorafgaande aan het onderzoek, één van de volgende hypnotica ingenomen: nitrazepam $5 \mathrm{mg}$, flunitrazepam I mg, temazepam 10-20 mg, flurazepam $15 \mathrm{mg}$. of lormetazepam $1 \mathrm{mg}$. Patiënten met ernstige lever- of nierfunctiestoornissen, myasthenia gravis, psychiatrische aandoeningen, alcoholisme, geneesmiddelmisbruik of dementie werden van het onderzoek uitgesloten.

Door de afwijkende chemische structuur en de andere plaats van aangrijpen op het GABA-receptor complex van zopiclon, kan bij overschakeling van langdurig benzodiazepine-gebruik op zopiclon niet worden uitgesloten dat ontwenningsverschijnselen van het vorige benzodiazepine optreden. Om die reden werd in dit onderzoek gedurende de eerste week de dosering van de vorige medicatie gehalveerd, terwijl zopiclon in de halve dosering (3.75 mg) werd toegevoegd. Vervolgens continueerde de patiënt zopiclon in de gebruikelijke dosering voor oudere patiênten $(3,75$ of $7,5 \mathrm{mg})$ gedurende twee weken.

De volgende parameters werden in het onderzoek gemeten: slaaplatentietijd, slaapduur, slaapkwaliteit, slaapdiepte, wakker worden 's nachts, kwaliteit van het ontwaken, effectiviteit van de medicatie, verdraagbaarheid medicatie en voorkeur van onderzocker en pariënt voor de gebruikte hypnotica.

\section{RESULTATEN}

De gemiddelde leeftijd van de 246 in het onderzoek betrokken patiënten was 79 jaar (spreiding 34-99). Her gemiddelde gewicht was 69,3 kg (spreiding 35-102).

De meeste patiënten gaven bij het begin van het onderzock, ondanks benzodiazepine-gebruik, meer dan één slaapstoornis aan. In tabel 1 is het type slaapstoornis in percentages aangegeven:

TABEL 1

Procentuele verdeling van de verschillende slaapstoornissen over de patiëntenpopulatie (gestandaardiseerd interviewmodel).
Moeilijkheden met inslapen

$74 \%$

Meer dan $2 x$ per nacht wakker worden

Te vroeg wakker worden

's Nachts langer dan 1 uur wakker liggen

's Morgens vermoeid wakker worden

Overdag last hebben van tekort aan slaap
$53 \%$

$36 \%$

$22 \%$

$22 \%$

$11 \%$

Globaal kan worden gezegd dat de onderzoekers het hypnotische effect van de slaapmiddelmedicatie in $9 \%$ als slecht beoordeelden, in $45 \%$ als matig en in $45 \%$ als goed. Patiënten werden, ondanks de soms goede slaapkwaliteit van het hypnoricum in het onderzoek opgenomen, vanwege onder andere de negatieve invloed op het dageliịks functioneren.

De gemiddelde tijd (mediaan) dat de vooraf gebruikte hypnotica-medicatie werd ingenomen was 8 maanden (range 4 weken - 18 jaar). In $60 \%$ van de gevallen 
werd temazepam ( $27 \%$ temazepam $10 \mathrm{mg}$ en $33 \%$ temazepam $20 \mathrm{mg}$ ), in $29 \%$ nitrazepam $5 \mathrm{mg}$, in $8 \%$ lormetazepam $1 \mathrm{mg}$, in $2 \%$ flunitrazepam $1 \mathrm{mg} \mathrm{en} \mathrm{in}$ $1 \%$ flurazepam $15 \mathrm{mg}$ ingenomen. Co-medicatie werd door $93 \%$ van de populatie gebruikt, waarvan $57 \%$ voor cardiovasculaire aandoeningen.

Op dag 0, 7 en 21 antwoordde de patiënt, ongeveer een half uur na het wakker worden op zeven vragen over de slaap en over de kwaliteit van het wakker zijn:

Vraag 1: Hoe lang duurde het voordat u gisteravond in slaap viel?

Vraag 2: Hoe lang heeft u geslapen?

Vraag 3: Hoe vindt u dat u vannacht heeft geslapen?

Vraag 4: Hoe diep heeft u vannacht geslapen?

Vraag 5: Bent u gedurende de nacht wakker geworden?

Vraag 6: Hoe slaperig voelt u zich nu?

Vraag 7: Hoe uitgeslapen voelt $\mathrm{u}$ zich nu?

De voorgecodeerde antwoorden konden voor deze 7 vragen als volgt variëren:

Vraag 1: heel erg lang $(=0)$....heel kort $(=6)$

Vraag 2: helemaal niet $(=0)$....heel lang $(=6)$

Vraag 3: heel erg slecht $(=0)$....uitstekend $(=6)$

Vraag 4: heel erg licht $(=0)$....heel diep $(=6)$

Vraag 5: heel erg vaak $(=0)$....helemaal niet $(=5)$

Vraag 6: heel erg slaperig $(=0)$....volkomen fit $(=5)$

200 Vraag 7: helemaal niet uitgeslapen $(=0)$....volkomen uitgeslapen $(=6)$

Gedurende de tweede en derde week van het onderzoek nam $42,7 \%$ van de patiëntenpopulatie zopiclon in halve dosering ( $3,75 \mathrm{mg}$ ) en $49,6 \%$ in hele dosering (7,5 mg). Van 7,7\% van de populatie was niet bekend welke dosering werd ingenomen. In de figuren 1 en 2 zijn de gemiddelde scores van de patiënten op de vragen $1 \mathrm{t} / \mathrm{m} 7$ grafisch weergegeven.

Bij alle slaapparameters blijkt een significante verbetering op te treden, zowel na de eerste week als na de derde week van de behandeling. Om de slaapkwaliteit en ochtendfitheid per patiënt na 3 weken zopiclon-gebruik te vergelijken met de slaapkwaliteit op het voorafgaande middel, kan aangegeven worden bij welk percentage van de patiënten een verbetering, verslechtering c.q. een gelijkblijven van de slaapparameters optreedt (Figuur 3). Een verbetering/verslechtering is als volgt gedefinieerd: na 21 dagen therapie is de score met minimaal 1 punt verbeterd/verslechterd en bij gelijkblijven van de parameters is er niets veranderd in de score.

Tijdens elk consult beoordeelde de arts het hypnotische effect van de vorige medicatie (dag 0, de combinatie benzodiazepine 1/2 dosering + zopiclon 1/2 dosering (dag 7) en zopiclon 3.75 of $7.50 \mathrm{mg}$ (dag 21). Ongeveer $43 \%$ van de populatie nam $3,75 \mathrm{mg}$ in en ongeveer $50 \%$ van de populatie nam $7.50 \mathrm{mg}$ in gedurende week 2 en 3 (bii $7 \%$ van de patiènten werd de juiste dosering niet genoteerd). Er werd geadviseerd de rweede onderzocksweek met de halve dosering te starten, waarna de dosering, indien nodig, tot 1 tablet kon worden 
FIGUUR 1

Gemiddelde scores van de patienten op dag 0,7 en 21 op de vragen 1.4

FIGUUR 2

Gemiddelde scores van

de patiēnten op dag 0,7 en 21 op de vragen 5-7
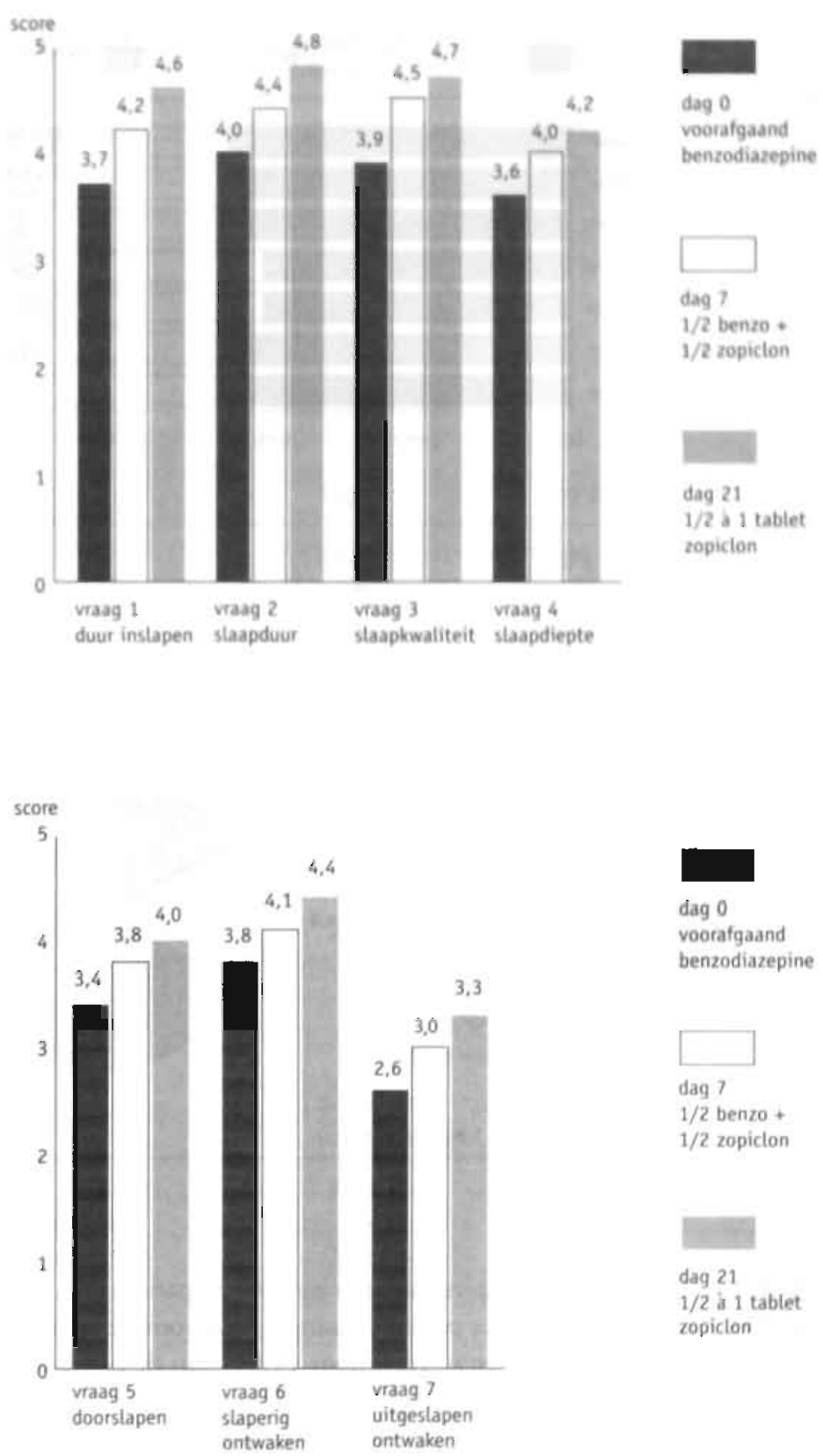

verhoogd. De uiteindelijke doșering is hier vermeld. Er werden geen criteria gegeven, waaraan de keuze tussen beide doseringen zou moeten voldoen. De uiteindelijke dosering hing af van de behoefte van de pariënt. In figuur 4 is weergegeven hoe de verpleeghuisarts de effectiviteit van de verschillende therapieèn beoordeelde. 
FIGUUR 3

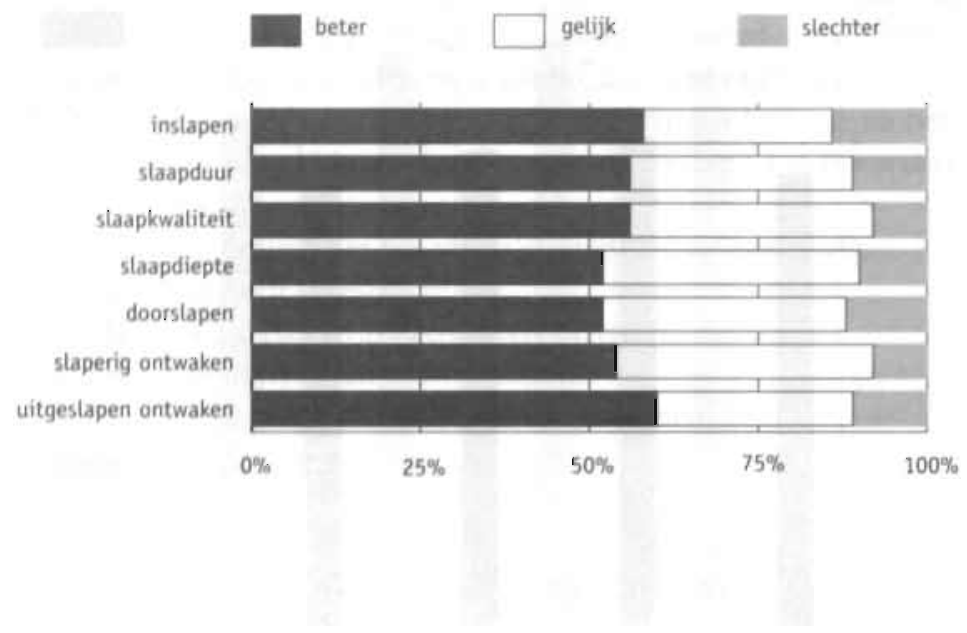

vorige medicatie

(dag 0)

goed 38,7

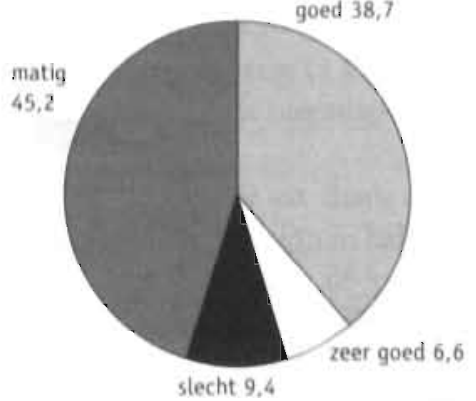

$1 / 2$ a 1 tablet zopiclon

(dag 21)

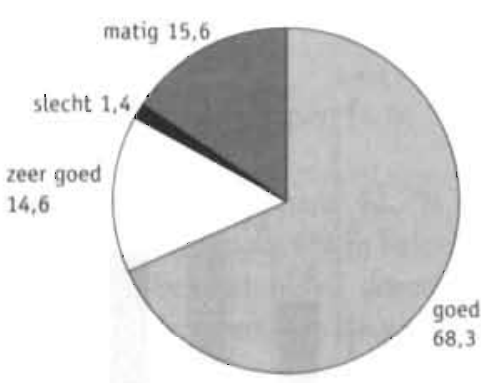

Percentages patiènten van wie de scores op de 7 vragen verbeterden, gelijk bleven of verslechterden in vergelijking met het voorafgebruikte benzodiazepineslaapmiddel.

\section{FIGUUR 4}

Beoordeling door de: verpleeghuisarts van het hypnotisch effect. van dè verscnitiènde therapieên op dag 0 . en dag $21(\%)$

Op dag 0,7 en 21 gaf de verpleeghuisarts aan hoe de patiènt zich overdag voelde. In tabel 2 zijn de percentages patiënten aangegeven voor de verschillende scores op dag 0 en 21. Bijwerkingen werden door $11,0 \%$ van de patiënten na de eerste week gemeld en door $10,2 \%$ op dag 21 .

In tabel 3 is een overzicht gegeven van de verschillende bijwerkingen op dag 7 en 21. De bijwerkingen waren over het algemeen licht van aard.

Op de laatste dag van het onderzoek gaven zowel arts als patiënt aan, aan welk hypnoticum men de voorkeur gaf. In tabel 4 staan de percentages vermeld. Van de 246 patiënten die in het onderzock zijn opgenomen zijn 28 patiënten vroegtijdig uitgevallen, waarvan 11 in de eerste week en 15 in de volgende twee weken (van 2 patiënten is dit gegeven niet bekend). In tabel 5 staan de redenen beschreven, waarom deze pariënten niet verder werden behandeld. 
TABEL 2

Beoordeling door de verpleeghuisarts hoe

de patient zich overdag voelde op dag 0 en dag 21 .
Beoordeling verpleeghuisarts

Redelijk uitgestapen

Matig uitgeslapen

Beetje slaperig

Erg slaperig, duf
Vorige medicatie Zopiclon (dog 0) (dog 21)

$\begin{array}{rr}9,9 \% & 19,0 \% \\ 36,3 \% & 60,2 \% \\ 24,9 \% & 14,4 \% \\ 20,4 \% & 5,1 \% \\ 8,6 \% & 1,4 \%\end{array}$

TABEL 3

Bijwerkingen die door de patiènt werden gemeld op dag 7 en dag 21 (in

"s) en het totaal percentage patiénten met bijwerkingen.

\section{Soort bijwerking}

Bittere smaak

Moe, slaperig, suf

Droge mond

Gastro-intestinale klachten

Hoofdpijn

Dromen, nachtmerries

Spierzwakte

Hypoglycaemie

Kwijlen

Duizeligheid

$\%$ Patiënten met bijwerkingen
$\operatorname{Dag} 7$

Dag 21

\section{$5,6 \%$}

$6,0 \%$

$2,4 \%$

$0,4 \%$

$1,2 \%$

$0,8 \%$

$1,2 \%$

$1,2 \%$

$0,8 \%$

$0,4 \%$

$0,4 \%$

$0,4 \%$

$0,4 \%$

- $1,6 \%$

$11 \%$

$10,2 \%$

TABEL 4

Voorkeursuitspraken van patiënten en artsen.

TABEL 5

Redenen van voortijdig staken medicatie/uitval.

van de
uitval.

Ineffectiviteit medicatie

$\%$ Voorkeur

van patiënten

$53 \%$

zopiclon

vorige benzodiazepine

geen voorkeur.
$8 \%$

$39 \%$
$\%$ Voorkeur van verpleeghuisarts

$56 \%$

$5 \%$

$39 \%$

Bijwerkingen

Verhuizing, ziekenhuisopname

Aantal

Slechte medicatie-compliance

Patiënt gebruikte geen medicatie meer

Ontslag uit verpleeghuis 
CONCLUSIE

Bij oudere verpleeghuispariënten met slaapproblemen is zopiclon een effectief en veilig hypnoticum dat een goed alternatief biedt voor de benzodiazepine-slaapmiddelen. 


\section{IITERATUUR}

1. Mulder HC Ruskmp FM. Enkele gogevens over her getoruik van nustgovende middelen en her voorkomen van slapeloosheid bij mensen van 65 jar en ouder in de gemeente Gironingen. Ned Tijdschrift Gerontol $1976: 767-73$.

2. Spicgd R. Advances in slocp rescarch. wol. 5. In: Weiraman ED, Slexp and slesplesaness in advanoed age. Lancaster MTP Pros Led, 1981.

3. Miles L., Dement WC Sleep and Aging. Sleep 1980:3:119-20.

4. Hoofdakker RH v.d., Goensch H. Slapeloonheid bij bejaanden. Pharm Weekblad 1979:114:1131.

5. Haijer-Rusbamp FM, Dingrmans CAJ. Bychofarmacapebruik bij ouderen. Tevel( $)$ van het goede: Practitioner 1988:14:1007-13.

6. Schols JMGA. Slapproblemen en dapmiddelengebruik in een verplecghtuis. Fen inventariscrend onderoek. Tijdachr Gerontol Geriatr 1991:22:139-42.

7. Schols JMGA. Slapproblemen is her verplecghais en de behandeling evan. TGOJDR 1993:18(2) 42.5.

8. IMS. Diagnose, informatic en medische statistick (DIMS). Slaapstoomisen: veranderingen in de farmacotherapie (1983 verus 1988). Gegeveru juli 1989.

9. Jovanowic U), et al. Dolygrsphical slexp recondings is insomniac patiens under Zopiclone or Nitrasepam. Pharmacology 1983:27 (suppl. 2):136-45.

10. Billiard M, et al. Doneresponse effects of zopiclone on night sleep and on nightrime and daytime functioning. Sleep 1987:10 (suppl. 1):27-34.

11. Mouret J, et al. Zopidone verus Trianolam in insomniac geriatric patienss a specific increase in delu sleqp with zopidone. Int Clin Psychopharm 1990;5 (suppl, 2):47-55.

12. Fossen A. et al. Effects of bypnoties on memory. Pharmacoloqy 1983;27 (suppl. 2):116-26.

13. Subhan Z, et al. Effects of zopidone and benzodiazepine hypnotics on search in thort-term memory. Neuropsychobiology 1984:12:244-8.

14. Ranlov PJ. et al. Effeces of zopidone and diazepam on ventilatory response in normal human subjects. Sleep 1987;10 (suppl. 1):40-7.

15. Wildschiodz G, et al. Effect of zopidone in sleep related zespiratory disorders. 5th International Congress of Sleep Research, Deamark. 1987.

16. Muir JE, et al. Comparative study of the effects of zopidone and placebo on respiratory function in patiens with chronic obstructive respiratory insufficiency. in Clin Psychopharmacology 19900;5 (suppl. 2):85-94.

17. Beaupré A, et al. Respiratory Center outpus following zopiclone or diazepam administration in patients with pulmonary disease. Respiration 1988:54:235-40.

18. Ueki S, et al, Behavioral pharmacology of zopiclone. Sleep 1987;10 (suppl. 1):1-6.

19. Julou L, et al. Pharmacological studies on zopiclone. Pharmacology 1983:27 (suppl. 2):46-58.

20. Allain H, et al. Postmarketing Surveillance of Zopiclone in Insomnia: Analysis of 20.513 Cases. Slecp 1991:14 $(5): 408-13$ 


\section{TOEGENOMEN STERFTE VAN VERPLEEGHUISPATIËNTEN BIJ EXTREME BUITENTEMPERATUUR; TOENAME GROTER BIJ HITTE DAN BIJ KOUDE}

Gepubliceerd in Nedertands Tijdschrift voor Geneeskunde 1997: 161: 2180-3

Dit onderzoek werd ook jepubticeerd in The Lancet (1997;349: 1297-8) met als titel Heat-related mortatity among nursinghome patients' [letter].

\section{Borst, J.M.G.A. Schols en J.P. Mackenbach}

\section{SAMENVATTING}

Doel. Bepalen van de invloed van de buitentemperatuur op sterfte van verpleeg: huispatiënten en aanwijzen van risicogroepen voor sterfte tijdens hitte en koude. Opzet. Analyse van sterftegegevens uit de SIG Verpleeghuis Informatie Systeem (SIVIS)-registratie (over de periode 1 januari 1993-31 december 1994)。

Plaats. Alle 289 verpleeghuizen $(89,5 \%)$ in Nederland die hun gegevens bij SIG Zorginformatie registreren.

Methode. Van SIG Zorginformatie werden per week aanwezigheids- en overlijdenscijfers verkregen met onderscheid naar geslacht, leeftijd, algemene dagelijkse levensverrichringen (ADL) en hoofddiagnosen. Gemiddelde maximale weektemperaruren werden verkregen van het KNMI. Sterftecijfers en relatieve risico's werden berekend voor temperatuurbereiken van $5^{\circ} \mathrm{C}$ voor alle variabelen.

Resultaten. Indien de gemiddelde maximale weektemperatuur boven $25^{\circ} \mathrm{C}$ steeg. was er een toename van het sterftecijfer van de verplecghuispopulatic van $50 \%$ ten. opzichte van perioden met optimale temperaturen $\left(15-19,9^{\circ} \mathrm{C}\right)$. Tijdens koude perioden $\left(0-4,9^{\circ} \mathrm{C}\right)$ was de toename van het sterftecijfer veel minder groot $(22 \%)$. Risicofactoren voor een verhoogde sterfte tijdens hoge temperaturen waren: vrouwelijk: geslacht, grote ADL-afhankelijkheid en de diagnosen: dementie, amnestisch syndroom of ziekte van Parkinson. Risicogroepen voor verhoogde sterfte rijdens lage temperaturen waren: zeer hoge leefrijd (> 95, jaar), ADL-zelfstandigheid, ziekte van Parkinson, cardiovasculaire ziekte, chronische obstructieve longziekte, ziekte van het bewegingsapparaat en bindweefsel en een heupfractuur. Conclusie. Verpleeghuispatiënten bleken zeer kwetsbaar te zijn als de buitentemperaturen boven $25^{\circ} \mathrm{C}$ stegen. Hoge temperaturen hadden een veel grotere invloed op de sterfte dan lage.

\section{SUMMARY}

Increased mortality among nursing home patients during ambient temperature extremes: more rise during hot than during cold'spells.

objective. To investigate the effect of ambient air temperatures on mortality among: nursing home patients, and to identify subgroups of patients particulary vulnerable to effects of heat and cold.

Design. Analysis of mortality data from SIG Nursing Home Information System (SIVIS) recorded in 1993 and 1994. Setting. All 289 Dutch nursing homes. $(89.5 \%)$ that register patient data at SIG Zorginformatie, Utrecht.

Methods. For each week numbers of patients present and deceased were obtained subclivided by sex, age, level of dependence, and diagnoses. Weekly averages for maximum daily outdoor air temperatures were obtained from the Dutch national metereologic institute (KNMI), De Bilt.

Results. The lowest mortality rates were observed in weeks with average outdoor temperatures between 15 and $19,9^{\circ} \mathrm{C}$. In the coldest weeks $\left(0-4,9^{\circ} \mathrm{C}\right)$ the mortality rate rose by $22 \%$. As outdoor temperatures rose above $25^{\circ} \mathrm{C}$, the mortality rate rose by $50 \%$. The highest relative risks of dying during the cold winter spells were 
observed among patients of advanced age ( $>95)$, who were independent in activities of daily living and who had Parkinson's disease, cardiovasculair disease; COPD, disease of locomotor system and connective tissue or a hip fracture. The highest relative risks of dying during the hot summer spells were observed among the female population, patients with a high level of dependence in activities of daily living, and patients with dementia, amnestic syndrome or Parkinson's disease.

Conclusions. Nursing home patients were extremely vulnerable when outdoor temperatures rose above $25^{\circ} \mathrm{C}$. High temperatures had much more effect on mortality rates than low temperatures.

\section{INLEIDING}

Weersomstandigheden beinvloeden de morbiditeit en de mortaliteit van mensen over de gehele wereld. Diverse onderzoeken hebben aangetoond dat in de wintermaanden een grotere sterfte onder de bevolking plaatsvindt, in het bijzonder door toename van de cardiovasculaire mortaliteit. ${ }^{\text {it }}$ Wetenschappelijke publicaties beschrijven eveneens een toename (15-30\%) van de mortaliteit tijdens hitteperioden. ${ }^{6 / 4}$ Mackenbach et al. vermeldden dat de sterfte in Nederland het laagst is bij $20,5^{\circ} \mathrm{C}$.

Ouderen blijken tijdens perioden met zeer hoge temperaturen tot de grootste

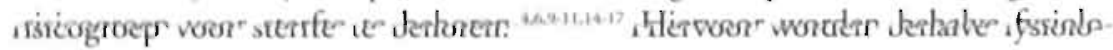
gische verouderingsfenomenen ook diverse andere oorzakelijke factoren aangewezen, waaronder de frequente aanwezigheid van chronische ziekten en comorbiditeit; polyfarmacie; beperkingen, handicaps en afhankelijkheid. ${ }^{+12.14-18}$

Er is nog weinig bekend over het effect van de buitentemperatuur op de mortaliteit van verpleeghuispatiënten. Op basis van hun gemiddelde leefrijd en de frequentie van chronische ziekten, polyfarmacie en beperkingen, zou verondersteld mogen worden dat zij extra kwetsbaar zijn tijgdens hitte en koude.

Verplecghuispatiënten staan niet vaak bloot aan echt lage temperaturen. In de zomer daarentegen beinvloede de buitentemperaruur direct de binnentemperatuur, waardoor de verpleeghuispatiënt soms wel blootstaat aan hoge temperaturen. De resultaien van een onderzoek naar invloeden van omgevingstemperaturen op sterfte zouden belangrijke beleidsimplicaties kunnen hebben voor de verpleeghuissector als geheel.

Derhalve hebben wij een onderzoek verricht om antwoord te kunnen geven op de volgende twee vragen: In welke mate is er een samenhang tussen de buitentemperatuur en de sterfte in de Nederlandse verpleeghuizen? Welke verpleeghuispatiënten behoren tot de risicogroepen voor toegenomen sterfte tijdens hoge en lage temperaturen?

\section{PATIËNTEN EN METHODE}

Het onderzock betrof een retrospectieve analyse van sterftegegevens over de periode januari 1993 tot en met december 1994. Het onderzoek had betrekking op de patiënten uit alle 289 verpleeghuizen $(89,5 \%)$ die hun patiëntengegevens registreren bij SIG Zorginformatie te Utrecht (het totale aantal verpleeghuizen in Nederland is 323). In de le week betrof dit 48.652 patiënten; geleidelijk steeg dit aantal tor 50.659 in de laatste week.

Patiëntenkenmerken, 'aanwezigheidscijfers' (het aantal aanwezigen per verpleeg- 
huis) en overlijdenscijfers werden bewerkt naar geslacht, 5 leefrijdscategorieèn (<65 jaar, 65-74 jaar, 75-84 jaar, 85-94 jaar en $\geq 95$ jaar), 5 verschillende categorieèn wat betreft algemene dagelijkse levensverrichtingen (ADL) en de 10 meest voorkomende hoofddiagnosen voor opname, inclusief een restgroep. Het niveau van afhankelijkheid werd bepaald door de score van 6 geselecteerde ADLgegevens (wassen, kleden, continentie, eten, lopen en transfers) te cumuleren zodat een score van 0 tot 24. ontstond. Uit de gecumuleerde score werden 5 ADL-categorieèn gevormd, waarbij categoric 1 overeenkwam met grote zelfstandigheid (score 0-4) en categorie 5 met volledige afhankelijkheid of bedlegerigheid (score 20-24). De ADL-gegevens worden 3-maandelijks door de verpleging geactualiseerd. De toekenning van de diagnose vond plaats door de verpleeghuisarts op basis van de SIG Verplecghuis Informatie Systeem (SIVIS)-diagnoseclassificatic.

SIVIS-gegevens werden als volgt bewerkt: van elke week gedurende 1993 en 1994 werd op dag 1 het aantal aanwezigen in de verpleeghuizen vastgesteld en op dag 7 het aantal overledenen in de desbetreffende week. Persoonsweken werden (bij benadering) verkregen door het gemiddelde te berekenen van het aantal aanwezigen aan het begin en het einde van elke week.

De gemiddelde maximale temperaturen per week werden verkregen van het KNMI in De Bilt. Er werden 6 temperatuurbereiken van $5^{\circ} \mathrm{C}$ gevormd, (0$4,9^{\circ} \mathrm{C} ; 5-9,9^{\circ} \mathrm{C} ; 10-14,9^{\circ} \mathrm{C} ; 15-19,9^{\circ} \mathrm{C} ; 20-24,9^{\circ} \mathrm{C} ; 25-29,9^{\circ} \mathrm{C}$; hierin vielen respectievelijk $7,21,23,30,13$ en 6 weken.

De laatste 2 dagen van 1993 en 1994 werden buiten beschouwing gelaten, evenals week $48 \mathrm{t} / \mathrm{m}$ 51, omdat zich in deze weken in 1993 een griepepidemie voordeed met een anzienlijke toename van de sterfte in Nederland (bron: Nederlands Instituut voor Onderzoek van de Gezondheidszorg (NIVEL), Utrecht)." Uiteindelijk werden 100 weken in het onderzoek betrokken. Het NIVEL registreerde in februari en maart 1993 eveneens een griepgolf. De sterfte tijdens deze periode was echter veel geringer dan in de tweede griepperiode, zodat de gegevens over deze weken wel werden gebruikt in het onderzoek.

Voor alle variabelen werd, binnen elk remperatuurbereik, het sterftecijfer berekend per 1000 persoonsweken met 95\%-betrouwbaarheidsinterval (95\%-BI), op grond van de aanname dat her aantal overledenen een Poisson-verdeling volgt. Verder werd voor alle variabelen het relatieve risico voor sterfte berekend ten opzichte van de optimale condities, die in het temperatuurbereik vañ $15-19,9^{\circ} \mathrm{C}$ bleken te vallen.

Tenslotte werd naar inhaaleffecten van sterfte (compensatie-effecten) gekeken na de hittegolf van 1994 door gedurende 7 weken in juli en augustus waarin de hitte aanhield en 6 daaropvolgende weken met temperaturen die dichter bij de optimale kwamen $\left(16,5-21,7^{\circ} \mathrm{C}\right)$, per week het verschil tussen het absolute en het gemiddelde aantal sterfgevallen tijdens optimale omstandigheden $\left(15-20^{\circ} \mathrm{C}\right)$ te berekenen.

\section{RESULTATEN}

De laagste sterftecijfers werden gevonden in het temperatuurbereik van 15 . $19,9^{\circ} \mathrm{C}$ (tabel 1). Het sterftecijfer dat onder deze optimale condities gevonden werd, was 7,09 (95\%-BI: 6,95-7,22) per 1000 persoonsweken. Het sterftecijfer bij alle andere temperatuurbereiken was steeds statistisch significant hoger. 
In de koudste weken $\left(0-4,9^{\circ} \mathrm{C}\right)$ steeg het sterftecijfer ten opzichte van optimale condities met ongeveer $22 \%$ naar 8,64 (95\%-BI: 8,33-8,95). In de heetste weken $\left(25-29,9^{\circ} \mathrm{C}\right)$ bleek het sterftecijfer $50 \%$ hoger te zijn dan onder optimale omstandigheden (10,60 (95\%-BI: 10,23-10,97)).

De hitteperiode in juli en augustus 1994 hield 7 weken aan en leidde tot cen oversterfte van ongeveer 1250 verpleeghuispatiënten. In de daaropvolgende 6 weken was een gering inhaaleffect te zien met een ondersterfte van ongeveer 140 verpleeghuispatiënten. Uiteindelijk werd ten gevolge van de hitteperiode dus een absolute oversterfte gevonden van 1110 patiènten. Dit is ruim $5 \%$ van de totale sterfte in de Nederlandse verpleeghuizen per jaar (circa 20.000). De oversterfte tijdens koude was niet goed te berekenen, onder andere omdat de koudeperiode te versnipperd was (nier in een aaneengesloten periode).

Risicogroepen werden bepaald door na te gaan voor welke categorieën het relatieve risico op sterfte tijdens koude $\left(0-4,9^{\circ} \mathrm{C}\right)$ groter was dan 1,2 (het totale gemiddelde in die temperatuurcategorie) en tijdens hitte $\left(25-29,9^{\circ} \mathrm{C}\right)$ groter dan 1,5 .

Tijdens koudeperioden werd geen verschil in het relatieve risico op sterfte gevonden tussen mannen en vrouwen (toename van respectievelijk 22 en 23\%) (tabel 2). Wel was er een verschil naar leeftijd: de zeer oude (> 95 jaar) patiënten bleken meer risico te lopen (relatief risico: 1,44). Na indeling in ADL-categorieën bleek de zelfstandigste groep (categorie 1) het meeste risico te lopen $(1,45)$.

Voor de diagnosegroepen gold dat patiënten met de ziekte van Parkinson $(1,64)$, cardiale ziekte $(1,31)$, cerebrovasculair accident $(1,24)$, chronische obstructieve longziekte $(\mathbf{1}, 28)$, ziekte van her bewegingsstelsel en bindweefsel $(1,61)$ en een 210 heupfractuur $(1,34)$ e en sterker verhoogd risico liepen op sterfte tijdens koude. Tabel 2 geeft tevens aan dat vrouwen kwetsbaarder waren voor hitte dan mannen (58 versus 36\% toename). Er was geen duidelijke relatie tussen oversterfte tijdens hitte en leeftijd. Patiënten uit de ADL-groepen $4(1,50)$ en $5(1,58)$, en uit de diagnosegroepen: psychogeriatrische aandoeningen (dementie $(1,61)$ en amnestisch syndroom $(3,39))$ en de ziekte van Parkinson $(2,27)$ hadden binnen

\begin{tabular}{|c|c|c|c|c|}
\hline $\begin{array}{l}\text { Temperatuur } \\
\left(\text { in }^{\circ} \mathrm{C}\right)\end{array}$ & $\begin{array}{c}\text { sterfte } \\
\text { (absolute } \\
\text { aantallen). }\end{array}$ & $\begin{array}{l}\text { persoons- } \\
\text { weken. }\end{array}$ & $\begin{array}{l}\text { sterfte } \\
(95 \%-B I)\end{array}$ & $\begin{array}{l}\text { relatief risico } \\
(95 \%-B I)\end{array}$ \\
\hline $0-4,9$ & 2.996 & 346.707 & $8,64(8,33-8,95)$ & $1,22(1,17-1,27)$ \\
\hline $5,0-9,9$ & 8.387 & 1.048 .299 & $8,00(7,83-8,17)$ & $1,13(1,10-1,16)$ \\
\hline $10,0-14,9$ & 8.704 & 1.151 .989 & $7,56(7,40-7,71)$ & $1,07(1,04-1,10)$ \\
\hline $15,0-19,9$ & 10.632 & 1.500 .297 & $7,09(6,95-7,22)$ & $1,00(0.97-1,03)$ \\
\hline $20,0-24,9$ & 4.944 & 649.097 & $7.62(7.40-7.83)$ & $1,07(1,03-1,11)$ \\
\hline $25,0-29,9$ & 3.198 & 301.750 & $10,60(10,23-10,97)$ & $1,50(1,44-1,56)$ \\
\hline totaal & 38.861 & 4.998 .139 & $7,78(7,70-7,85)$ & \\
\hline
\end{tabular}

TABEL 1

Mortaliteit (per 1000 persoonsweken) van verpleeghuisbewoners. naar gemiddelde. maximale weektemperatuur in Nederland, 1993-1994

$95 \%-81=95 \%$-betrouwbaarheidsinterval.

hun categorie een sterkere oversterfte tijdens hitte:

Een uitvoerige multivariabele analyse werd uitgevoerd om na te gaan in hoeverre de afzonderlijke variabelen, onafhankelijk van elkaar, samenhingen met een verhoogd relatief risico op sterfte tijdens hitteperioden. Dit bleck vrijwel steeds 
Relatief risico nast patièntikenmerken voor sterfte tijdens koude- $\left(0-4,9^{*} \mathrm{C}\right)$

en warmteperiode

$\left(25,0-29,9^{*} \mathrm{C}\right)$

betreffende

verpleeghuis-

patiènten naar

geslacht, leeftijd,

ADL-afhankelijkheid en diagnose.

\begin{tabular}{|c|c|c|}
\hline 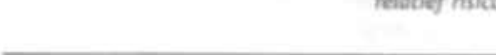 & $0-4,9^{\circ} \mathrm{C}$ & $25,0-29,9^{*} \mathrm{C}$ \\
\hline totaal & $1,22(1,17 \cdot 1,27)$ & $1,50(1,44-1,56)$ \\
\hline \multicolumn{3}{|l|}{ gesiacht } \\
\hline mannen & $1.22(1,14-1,30)$ & $1,36(1.27-1.46)$ \\
\hline vrouwen & $1,23(1,17-1,29)$ & $1.58(1,51 \cdot 1,66)$ \\
\hline \multicolumn{3}{|l|}{ leeftijd (in jaren) } \\
\hline$<65$ & $1,00(0.80-1.27)$ & $1,40(1.13 \cdot 1,72)$ \\
\hline $65-76$ & $1.11(0,98-1,27)$ & $1,34(1,18-1,52)$ \\
\hline $75-84$ & $1,26(1.18-1.35)$ & $1.55(1.46-1.66)$ \\
\hline $85-94$ & $1,25(1,17-1,33)$ & $1.52(1.43-1.62)$ \\
\hline$>95$ & $1.44(1.23-1.68)$ & $1,40(1,19-1,64)$ \\
\hline \multicolumn{3}{|l|}{$A D t$} \\
\hline groep 1 (in hoge mate zelfstandig) & $1,45(1,21-1,73)$ & $1,29(1,06 \cdot 1,56)$ \\
\hline groep 2 & $1,31(1,16 \cdot 1,47)$ & $1,29(1,14-1,46)$ \\
\hline groep 3 & $1,26(1,14-1,40)$ & $1,36(1,23-1,51)$ \\
\hline groep 4 & $1.19(1.11-1.27)$ & $1,50(1.40-1,61)$ \\
\hline groep 5 (volledig afhankelijk (bedlegerig)) & $1.22(1.13-1,31)$ & $1,58(1,48-1,68)$ \\
\hline \multicolumn{3}{|l|}{ diagnose } \\
\hline matigniteit & $1,04(0,90-1,19)$ & $0,98(0,85-1,14)$ \\
\hline dementie & $1,16(0,99-1,33)$ & $1,61(1,41-1,84)$ \\
\hline amnestisch syndroom & $0,83(0,32-2,17)$ & $3,39(1,81-6,35)$ \\
\hline ziekte van Parkinson/parkinsonisme & $1,64(1,04-2,61)$ & $2.27(1.47-3.52)$ \\
\hline cardiale ziekte & $1,31(1,18-1,44)$ & $1,25(1,12-1,39)$ \\
\hline CVA en late gevolgen van CVA & $1,24(1,10-1,40)$ & $1,41(1,24-1,59)$ \\
\hline $\begin{array}{l}\text { chronisch obstructieve longziekte } \\
\text { ziekten van het bewegingsapparaat }\end{array}$ & $1.28(0,92-1,77)$ & $1,38(0,99-1,94)$ \\
\hline $\begin{array}{l}\text { en het bindweefsel } \\
\text { heupfractuur en resttoestand na }\end{array}$ & $1,61(0,89-2,93)$ & $1,19(0,58-2,46)$ \\
\hline heupfractuur & $1,34(0,70-2.57)$ & $1,07(0,50-2,29)$ \\
\hline restgroep & $1,21(1,14-1,28)$ & $1,68(1,59-1,77)$ \\
\hline
\end{tabular}

relatief risico $(95 \%-B I)$ bij gemiddelde maximale woitemperatuur

$1,22(1,17 \cdot 1,27)$

$1.22(1.14-1.30)$

$1,00(0,80-1,27)$

$.25(1.17-1.33)$

$.44(1.23-1.68)$

$1,21(1,14-1.28)$

ADL = algemene dagelijkse levensverrichtingen; $95 \%$-BI $=95 \%$-betrouwbaarheidsinterval: CVA = cerebrovasculair accident.

her geval, behalve dat het vooral vrouwen waren met toegenomen sterfte tijdens hitte bij de diagnosegroepen dementie en cardiale ziekten. Omgekeerd hadden deze 2 diagnosegroepen geen effect op de toegenomen sterfte onder vrouwen.

\section{BESCHOUWING}

Verpleeghuispatiënten hadden overeenkomstig de verwachtingen veel te lijden onder zeer hoge omgevingstemperaturen. Tijdens hitte werd een veel grotere toename gevonden van het sterftecijfer van verpleeghuispatiënten (toename van $50 \%$ ) dan gedurende koudeperioden (toename van $22 \%$ ). In vergelijking met de Nederlandse bevolking was de toename van het sterftecijfer bij verpleeghuispariënten tijdens hitte veel groter $(9 \%$ versus $50 \%)$ dan tijdens koude $(11 \%$ versus $22 \%$ ) (tabel 3). Verder bleek dat, na een periode van grote sterfte ten gevolge van hitte, geen echte compensatoire ondersterfte werd waargenomen. Er was dus sprake van oversterfte.

De beperkingen van dit onderzoek liggen in de relatief korte onderzocksperiode met een gering aantal weken met zeer lage of hoge temperaturen. De resultaten 
TABEL 3

Risicocijfers voor sterfte naar gemiddelde maximale weektemperatuur voor de Nederlandse verpleeghuispopulatie en de bevolking.

komen desalniettemin goed overeen met resultaten uit eerder onderzoek. 12,46,11 Verder werd in dit onderzoek niet gekeken naar de overlijdensdiagnose.

De opvallende toename van het sterfterisico tijdens hitte bij psychogeriatrische patiënten alsook bij patiënten met de ziekte van Parkinson kan enerzijds samenhangen met aanwezige beperkingen ten aanzien van de gedragsmatige aanpassing aan hoge omgevingstemperaturen (aard van de kleding, vermijden van hete plaatsen, voldoende drinken etcetera) en anderzijds met pathofysiologische stoornissen (waaronder de temperatuurregulatie in het lichaam) en mogelijke effecten van psychofarmaca. ${ }^{x}$ In het verlengde hiervan wijst het hoge sterfterisico ten gevolge van hitte bij patiènten met ernstige ADL-stoornissen duidelijk op de beperkingen van veel verpleeghuispatiënten om effectieve, verkoelende maatregelen te 212 nemen.

De meeste verpleeghuispatiënten kwamen waarschijnlijk niet vaak buitenshuis als de buitentemperaturen laag waren; dit verklaart mogelijk de geringe toename van de sterftecijfers tijdens koude. Verpleeghuizen waren bovendien voorzien van goede centrale verwarmingsinstallaties, waarmee de temperatuur in de winter behaaglijk gehouden kon worden. Voorzieningen voor klimaatbeheersing in de zoner waren evenwel nauwelijks beschikbaar." Daarmee waren verpleeghuispatiènten in feite beter beschermo tegen lage dan hoge buitentemperaturen.

Met een te verwachten toenemend 'broeikas-effect' zullen wij in de roekomst wellicht nog vaker te maken krijgen met zeer hete zomers. ${ }^{22}$

Koeling is het effectiefste middel om de morbiditeit en de sterfte tijdens hitte te verminderen. ${ }^{1211,19,25}$ Bestaande interventiemogelijkheden in de verpleeghuizen bieden hier echter momenteel onvoldoende soelaas. Betere koeling kan gecreëerd worden door aanpassingen aan te brengen in de klimaatbeheersing en de bouwtechnische eigenschappen van verpleeghuizen, bijvoorbeeld door airconditioning, absorptickoelmachine of energieopslag. ${ }^{26}$ Indien het mogelijk zou zijn om tijdens hitteperioden de binnentemperatuur $5-10^{\circ} \mathrm{C}$ te doen dalen, zodat deze tussen de $20^{\circ} \mathrm{C}$ en de $25^{\circ} \mathrm{C}$ komt, zou op basis van de gegevens van dit onderzoek waarschijnlijk een aanzienlijke daling van de sterfte tijdens hitteperioden kunnen optreden; in de orde van $40 \%$. Voorts dienen verpleeghuizen te werken met goede vochttoedieningsprotocollen tijdens hitte. 


\section{LITERATUUR}

1. Mackenbach JR. Kunst AE, Looman CWN. Seasonal variarion in mortality in the Netherlands. I Epidemiol Community Health 1992: 46:261-5.

2. Kurat AE, Looman CWN, Mackenbucb JP. Ourdoor air temperarure and mortality in the Netherlands: a time-series analysih. Am J Epidemial 1993:137331-41.

3. Haherman S, Capildeo R, Rese FC. The seasonal variation in mortality from cerebrovasculat discase: J Neurol Sci 1981:52-25-36.

4. Bull GM. The weather and deaths from pneumonia. Lancet 1980;1:1405-8:

5. Manhall RJ, Scrapg R. Bourke P. An analyis of the seasonal variation of coronary heart diease and respiratory discose mortality in New Zealand. Int J Epidemiol 1988:17:325-31.

6. Pan WH. Li LA. Tai MJ. Temperarure caremes and mortality from coronary heart disease and cerelual infarction in elderly Chinec. Lance 1995:345:353:5.

7. Mackenbach IR: Kuns AE, Looman CWN. Verhoogde sterftr tijdens de hittogolf van bogin augusnus 1990. Ned Tijactir Genecokd 1991:135:182-3.

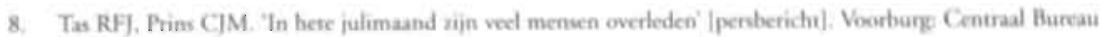
voot de Statisick, 1994.

9. Jones TS, Liang AP, Kilbourne EM, Griffin MR, Parriarca PA. Wasilak SG, et al. Modbidity and mortality associated with the July 1980 heat wave in St. Louis and Kansas City, Mo. JAMA 1982:247:3327-31.

10. Kanouyanni K, Pantaropoulou A. Touloumi G, Tedepidaki I, Moustris K. Asimakoponilos D, et al. Evidence for interaction berween air pollution and high temperature is the causation of ewes mortality. Arch Frnvion Health 1993; $48: 235-42$.

11. Macey SM, Schneider DE Deaths from excessive heat and excessive cold among the elderly. Gerontologist 1993:33:497-500.

12. From the Centers for Disease Control and Prevention. Heat-related deaths - Philadefphia and United States. 1993-1994. JAMA 1994:272:197.

13. Katsouyanni K. Karakarsani A. Messuri 1. Touloumi G. Harzakis A, Kalandidi A. et al. Air pollution and cause specific mortality in Athens. J Epideruiol Community Health 1990:44:321-4.

14. Kalkstein LS, Lessons from a very hot summer. Lancet 1995:346:857-9.

15. Hasanein T, Razack A. Gavaler JS, Thiel DH van. Heatstroke its dinical and pathological presentation, with particular attention to the liver. Am J Gastroentero! 1992:87:1382-9.

16. Kenney W1. Tankersley CG. Newswanger DL Hyde DE. Puhl SM. Turner NL. Age and hypohydration. independently influence the peripheral vascular response to heat stress. I Appl Physiol 1990;68:1902-8.

17. Kcatinge WR. Coleshaw SR. Easton JC. Cotrer F, Mattock MB. Chelliah R. Increased platelet and red cell counts, blood, viscosity, and plasma cholesterol levels during heat stress, and morraliry from coronary and cerebral thrombosis, Am J Med !986;81:795-800.

18. Kilbourne EM, Choi K. Jones TS, Thacker SB, Risk factors for hearstroke. A case-control study. !AMA 1982:247:3332-6.

19. Chas ECJ, Jong JC de, Bartelds AIM. Wiingaarden JK van, Masurel N, Osterhaus ADME. Influenza in het seizoen 1993/'94; vaccinsamenstelling voor her weizon 1994/95. Ned Tijdschr Genecked 1994:138:1966-9.

20. Finnheer R, Ven PJG van de. E.rkelens DW. Psychiatrische medicatie als risicofactor voor facale hirtecollaps. Ned Tijdschr Geneeskd 1995;139:1391-3.

21. Lemaire HA, Schoenmaker 1. Tropische toestanden in het verplecghuis. Techniek in de gezondheidszorg 1994:11:37-40.

22. Mourik B van. De wame periode in Nederland van september ' $87 \mathrm{t} / \mathrm{m}$ augustus ' 94 . Meteologica 1994:3:12-3.

23. Mourik B van. De kans dat 1991 warmer wordt dan 1990. Weerspiggel 1991:4:339-41

24. De toestand van bet klimaat en van de ozonlag in Nederland'. De Bils: Koninkliị Nederlands Metereologisch Insrituut, 1993 
25. Semenza JC, Rubin CH, Faller KH, Selanikio JD, Flanders WD, Howe HL, et al. Hear-related deaths during the July 1995 heat wave in Chicago. N Engl J Med 1996:335:84-90.

26. Duin W ven. Anders koclte scheppen. Zorgvisie 1997;30 mei:40-3. 


\section{WEEFSELDONATIE IN VERPLEEGHUIZEN; EEN ORIËNITATIE OP HET AANTAL POTENTIËLE DONOREN EN DE KENNIS EN ATTITUDE VAN VERPL.EEGHUISARTSEN EN -DIRECTIES,}

Gepubliceerd in Nederlands Tijdschrift voor Geneeskunde 1999 ; 143: 1153-7

\section{J.M.G.A. Schols en D.C. Berendschot-de Lange}

\section{SAMENVATTING}

Doel. Indruk verkrijgen van het aantal potentiële weefseldonoren in verplecghuizen alsmede van het kennisniveau en de attitude van verpleeghuisartsen en -directies ten aanzien van weefseldonatic en tenslotte van de knelpunten met betrekking tot weefseldonatic in verplecghuizen.

Opzet. Inventariserend, descriptief.

Methode. Schatting van het aantal weefseldonoren vond plaats door middel van bewerking van in 1995 geregistreerde gegevens van het landelijke SIG Verpleeghuis Informatic Systeem (SIVIS). Verder vond een schriftelijke enquête plaats onder alle 323 verplecghuisdirecties in Nederland alsmede onder 400 aselect gekozen verplecghuisartsen.

Resultaten. Van de 10.619 in 1995 overleden somatische verplecghuispatienten zouden $2670(25 \%)$ in aanmerking kunnen komen voor huid-en/of corneadonatie. De overige patiènten hadden comorbiditeit die gold als contra-indicatie voor donorschap of een leeftijd > 80 jaar. Van de 9771 overleden psychogeriatrische pariënten kwam er bijna geen in aanmerking als weefseldonor. De respons op de enquête was onder de verpleeghuisartsen 55\% en onder de direcries 66\%. Bij beide groepen. was er een gebrekkige kennis met betrekking tot weefseldonatie. De meeste verpleeghuisartsen $(85 \%)$ stonden neutraal tegenover weefseldonatic in verpleeghuizen; de meeste directies $(88 \%)$ zouden weefseldonatie in hun verpleeghuis ondersteunen. Van de aangegeven knelpunten voor donatie scoorden de items 'eeni gebrekkige kennis bij artsen' en 'weigering van toestemming voor donatie' bij beide groepen het hoogst.

Conclusie. Per jaar zouden ongeveer 2700 somarische verpleeghuispatiènten weefseldonor kunnen zijn. Een bepaling van hun donatiebereidheid is aangewezen. Een actievere benadering van weefseldonatie in verpleeghuizen vereist een verbetering van her kennisniveau van de artsen en de directies.

\section{SUMMARY}

Tissue donation in nursing homes; an orientation regarding the number of potential donors and the knowledge and attitude of nursing home physicians and directors Objective. To obtain an impression of the tissue donor potential in Dutch nursing homes and of the knowledge and the atritude of nursing home physicians and nursing home directors with regard to tissue donation. Also, to gain insight into the problems associated with activating tissue donation in nursing homes.

Design. Descriptive and inventory.

Method. The donor potential was calculated from data derived from the National nursing home registration system (SIVIS) in 1995. A questionnaire on the knowledge and attitude with regard to organ/tissue donation was sent to 400 randomly chosen nursing home physicians and all 323 nursing home directors. Results. Out of the 10,619 somatic patients deceased in nursing homes in 1995 . $2670(25 \%)$ would have been suitable for skin and/or cornea donation. Other 
patients had comorbidity regarded as a contraindication for donorship or were over 80 years of age. Of the 9771 deceased psychogeriatric patients, virtually none were suitable as tissue donors. The response to the questionnaire was 55\% among nursing home physicians and 66\% among nursing home directors. Both groups showed inadequate knowledge with regard to tissue donation. Most nursing home physicians ( $85 \%$ ) took a neutral position on tissue donation in nursing homes; most directors $(88 \%)$ would support tissue donation in their nursing home. The two problems that were mentioned most in having a negative influence on tissue donation in nursing homes, were: the lack of knowledge of physicians and the refusal of donation by patients.

Conclusion. Some 2700 somatic nursing home patients annualy would be suitable for tissue donation. Determination of their willingness is necessary. Activating of tissue donation in nursing homes requires solving of the lack of knowledge.

\section{INLEIDING}

In mei 1996 is door het parlement de Wet op de Orgaandonatie (WOD) aangenomen.' In her kader van de WOD kunnen Nederlandse burgers van 18 jaar en ouder hun wensen omtrent orgaan- en weefseldonatie laten vastleggen in een landelijk donorregister. De WOD verplicht de besturen van ziekenhuizen en verpleeginrichtingen tot het vaststellen van een protocol met betrekking tot orgaan- en weefseldonatie en tot het toezien op de naleving ervan. ${ }^{\text {. }}$.

Orgaan- en weefseldonatie genieten in verpleeghuizen nog nauwelijks bekendheid en donaties vinden er slechts zelden plaats. Zo vonden in 1998 vanuit verpleeg216 huizen 6 corneadonaties plaats; ongeveer net zoveel als in de 5 voorafgaande jaren tezamen. Van donatie van andere weefsels was al helemaal geen sprake.' Over orgaan- of weefseldonatie in verpleeghuizen is dan ook nog nauwelijks geschreven. Weefseltransplantatie is in Nederland veel minder bekend dan orgaantransplantatie. Hoewel hes potentiële aantal donoren voor weefseltransplantatie wellicht hoog is, bestaat er een groot tekort aan weefsels.' Voor het opheffen van dit tekort zou ook een eventueel donorpotentieel uit de verpleeghuizen van belang kunnen zijn.

Gezien hun gemiddeld hoge leeftijd ( 75 jaar) zal bij verpleeghuispatiënten vooral donatie van huid en cornea een rol kunnen spelen. Voor huiddonatie bedraagt de maximale leeftijd circa 90 jaar en voor corneadonatie circa 80 jaar. Bovendien is voor weefseldonatie geen intacte circulatie vereist. Afname van de betreffende weefsels kan geschieden tot 24 uur na het overlijden. ${ }^{6 .}$

In het kader van de nieuwe wetgeving wordt ook van de verpleeghuisarts verwacht dat deze, na het constateren van de dood, nagaat of er sprake is van een wilsbeschikking met betrekking tot donatic (onder andere door het raadplegen van het centrale donorregister). Wanneer er geen wilsverklaring is, moet de arts aan de nabestaanden de donatievraag stellen. Indien er daadwerkelijk een potentiële weefseldonor is, moet de arts die de dood heeft vastgesteld er zorg voor dragen dat deze donor wordt aangemeld bij een orgaancentrum.'

Aangezien her in de verpleeghuizen over het algemeen zal gaan om weefseldonatie, zal aunmelding moeten geschieden bij de Stichting Bio Implant Services (BIS). Deze organisatie zorgt voor de uit-en afname van weefsels en kan ook altijd worden geraadpleegd bij twijfel over eventuele contra-indicaries voor donatie. Natuurlijk zijn er naast de relatieve onbekendheid nog meer knelpunten denkbaar 
die een rol kunnen spelen wanneer men de mogelijkheden voor donatie in verpleeghuizen nader beschouwt. ${ }^{10} \mathrm{Zo}$ is er nog onduidelijkheid omtrent het donorpotentieel en de daadwerkelijke donatiebereidheid van patieñnten. Verder is het fenomeen van officiele wilsverklaringen betrekkelijk nieuw in de verplecghuissector en zal men bij de uitvoering van donatieprocedures aanvankelijk ook op organisatorische en logistieke (inclusief technische) problemen stuiten.

Op grond van deze overwegingen en vanwege de nieuwe wetgeving hebben wij een onderzoek verricht met betrekking tot weefseldonatie in verpleeghuizen.

De hoofdvraagstellingen van dit onderzock betroffen:

- Wat is het potentiele aantal weefseldonoren (huid en/of cornea) per jaar in. Nederlandse verpleeghuizen?

- Hoe zijn het kennisniveau en de attitude van zowel verpleeghuisartsen als -directies met betrekking tot weefseldonatic in verpleeghuizen?

- Welke knelpunten zullen in de ogen van de artsen en de directies een belangrijke rol spelen bij de implementatic van de WOD in verplecghuizen?

\section{METHODE}

Wij verrichtten een inventariserend, descriptief onderzoek. Om een schatting te kunnen maken van het potentic̈le aantal weefseldonoren in Nederlandse verpleeghuizen, gebruikten wij de opname- en overlijdensdiagnosen uit het SIG Verpleeghuis Informatie Systeem (SIVIS-registratic). Als peiljaar werd 1995 genomen. In dat jaar registreerde $89,5 \%$ van de verpleeghuizen hun patiëntengegevens bij de SIG." De gebruikte SIVIS-diagnoselijst is afgeleid van de 'International classification of diseases' (ICD-9) of de 'Classificatie van ziẹten' (CvZ-80). Het registratieformulier biedt de mogelijkheid om naast de primaire overlijdensdiagnose tevens twee van de belangrijkste tot het overlijden bijdragende nevendiagnosen te registreren (relevante comorbiditeit). ${ }^{2}$ Berekend werd hoeveel verpleeghuispatiënten in aanmerking zouden komen voor huid- en/of corneadonatie, na selectie op basis van leeftijdscriteria en de relatieve en absolute contra-indicaties voor donatie van huid en cornea. Voor de donorselectie werd daarbij het model-ziekenhuisprotocol 'Orgaan-/weefseldonatie' van de Nederlandse Transplantatie Vereniging gehanteerd.'

Voor de andere hoofdvraagstellingen werd verpleeghuisdirecties en -artsen in 1997 een uitvoerige schriftelijke vragenlijst toegezonden, bestaande uit gestructureerde vragen met mogelijkheden tot schriftelijke toelichting. De vragenlijst ( 50 vragen) voor de artsen werd verzonden aan een aselecte steckproef van 400 van de in totaal circa 1000 Nederlandse verpleeghuisartsen. De vragenlijst (25 vragen) voor de directies werd verzonden aan alle 323 verpleeghuisdirecties in Nederland.

Data-analyse vond plaats in samenwerking met het Nationaal Ziekenhuisinstituut (NZi) te Utrecht.

\section{RESULTATEN}

Aantal potentiële weefseldonoren

In 1995 overleden in Nederlandse verpleeghuizen 10.619 somatische patiënten van wie de gegevens bij de SIVIS werden geregistreerd. Van hen was 39,2\% man en $60,8 \%$ vrouw. Na selectie op basis van de medische contra-indicaties (tabel 1) onder zowel de primaire overlijdensdiagnose als de belangrijkste tweede en derde nevendiagnose, bleef een groep over van 4927 patiënten (46\%). Als maximale 
- sepsis bij overlijiden

- actieve systemische infecties, waaronder bacteriele endocarditis meningitis (bacterieel en viral) tuberculose, lepra, Lyme-ziekte, malaria subacute scleroserende panencefatitis of encefalitis door onbekende oorzak rabies

difterie, roodvonk, doorgemaakte syfitis actieve herpes zoster doorgemaakte poliomyelitis

- recente vaccinatie met verzwakt levend virus ( 44 weken)

rubella

polio(-Sabin)-vaccin per os mazelen (rubeola)

gele koorts

bof

rabies

- leukemieên en kwaadaardige ziekten van het lymfestelsel

- hemodilutie: indien wegens bloedverlies > 50\% van het circulerend volume is vervangen door plasma en plasmavervangende preparaten binnen yoorgaande 48 uur

- onbekende doodsoorzaak, tenzij obductie volgt

- HIV, hepatitis B of C, humaan T-cellymfotroop virus of risicofactoren hiervoor

- degeneratieve ziekten van het zenuwstelsel van onbekende oorsprong (of risicofactoren hiervoor), zoals prionproteine-infecties

subacute spongiforme encefalopathie

(Creutzfeldt-Jakobsyndroom, Gerstmann-

Sträusster-Scheinker-syndroom; koeroe; fatale

famitiale insomnie)

motorneuronziekte, bijv, amyotrofische laterale

sclerose

multiple sclerose

ziekte van Alzheimer

onbenoemde, 'waarschijntijk' degeneratieve

aandoening van het zenuwstelsel

- chemotherapie of immunnsuppressiva indien

toegediend binnen voorafgaande 3 maanden

- intoxicaties.

lithiumcarbonaat

lood, chroom, andere zware metalen

ontbladeringsmiddelen (parathion)

pesticiden

arsenicum

kwik

Contra-indicaties voor weefseldonatie ?

leeftijdsgrens werd voor de berekeningen 80 jaar aangehouden (dat is de leeftijdsgrens voor corneadonatic). Op basis daarvan viel $37,3 \%(n=720)$ van de mannen en $51,3 \%(n=1537)$ van de vrouwen af. Uiteindelijk bleven er 2670 patiènten $(25 \%)$ over die in principe in aanmerking zouden kunnen komen voor donatie van huid en/of cornea. Aangezien voor huiddonatie de maximale leeftijdsgrens wat hoger ligt (90 jaar), zou het percentage potentiële huiddonoren in feite wat hoger kunnen zijn.

In 1995 overleden 9771 psychogeriatrische pariënten in verpleeghuizen van wie 
de overlijdensdiagnose(n) bij de SIVIS geregistreerd werden. Bij bijna $90 \%$ van deze patiěnten was sprake van de diagnose 'dementie'. Onder de resterende $10 \%$ was een groot aantal patiēnten met de diagnose 'organisch psychosyndroom', andere neurodegeneratieve aandoeningen en cognitieve aandoeningen e.c.i. Aangezien deze diagnosen allemaal als absolute contra-indicaties gelden (zie tabel 1), waren er dus vrijwel geen psychogeriatrische verplecghuispatiênten die in aanmerking zouden komen voor weefseldonatic.

\section{Enquêtes}

Bij de geènquêteerde groep verpleeghuisartsen $(n=400)$ bedroeg de respons $55 \%$ (218 vragenlijsten). Van de 323 aan directies verzonden vragenlijsten werden er 212 ingevuld geretourneerd $(66 \%)$. In het algemeen werden de gestructureerde vragen door beide onderzocksgroepen volledig ingevuld; van de mogelijkheid tot toelichting werd nauwelijks gebruikgemaakt.

\section{Verpleeghuisartsen}

Van de responderende artsen was de man-vrouwverdeling ongeveer gelijk (105 $(48 \%)$ versus $109(50 \%))$. lets meer dan de helft $(113 ; 52 \%)$ was ouder dan 40 jaar en een redelijk percentage had eerdere werkervaring in een ziekenhuis (87; $40 \%)$ of als huisarts $(59 ; 27 \%)$.

Van de arts-respondenten waren $183(84 \%)$ in grote lijnen op de hoogte van de huidige donorwetgeving en $166(76 \%)$ enigszins van de veranderingen die op het gebied van de wetgeving op komst waren. Het merendeel van de artsen. (159; $73 \%$ ) kende globaal de medische criteria en contra-indicaties voor weefseldonatie. Ook de procedure die doorlopen moet worden na het overlijden van een potentiële (weefsei)donor was bij vele artsen $(131 ; 60 \%)$ marginaal bekend. Er werd ook een aantal concrete kennisvragen gesteld, waarop zeer wisselend werd gescoord en waarbij geen duidelijk verschil bleck te bestaan tussen de kennis over orgaan- en weefseldonatie specifiek en die over donorwetgeving. Bij de grootste groep $(155 ; 71 \%$ ) was sprake van een laag tot gemiddeld kennisniveau. Tweederde van de arts-respondenten was bekend met de werkwijze en de doelstellingen van de Stichting Eurotransplant. Er bleken 37 (17\%) ondervraagden de Stichting Bio Implant Services te kennen.

Bijna alle artsen $(198 ; 91 \%)$ gaven aan dat zij er behoefte aan hadden om in de toekomst op de hoogte te worden gehouden van verdere ontwikkelingen op het gebied van orgaan- en weefseldonatie. Overigens had driekwart van de verpleeghuisartsen nog nooit de donatievraag gesteld; ook niẹt in een eerdere functie, terwijl toch een behoorlijk aantal van hen $(87 ; 40 \%)$ voorheen in een ziekenhuis had gewerkt. Het merendeel $(155 ; 71 \%)$ bleek het stellen van deze vraag nooit te hebben overwogen of er nooit mee te maken hebben gehad. De meesten (183; $84 \%$ ) bleken voorstander te zijn van orgaan-en weefseldonatie in het algemeen en het merendeel $(174 ; 80 \%)$ gaf aan ook zelf donor te willen zijn.

Wanneer wij kijken naar de attitude van de ondervraagde artsen ten opzichte van weefseldonatie in het verpleeghuis blijkt dat 18 ! (83\%) van hen de verplecghuispatiënt als potentiële weefseldonor beschouwden en dat ruim driekwart in principe ook bereid zou zijn om eventuele weefseldonatie in de tockomst structureel met patiënten te gaan bespreken. Velen gaven aan dit te willen doen enkele weken na opname in het verpleeghuis. Tabel 2 geeft een indicatie van de attirude van de 
artsen ten aanzien van donatie in het algemeen en weefseldonatie in het verpleeghuis in het bijzonder. De atritude ten opzichte van weefseldonatie in het algemeen was positiever dan die ten opzichte van weefseldonatie in het verpleeghuis, die over het algemeen neutraal was.

Tabel 3 toont de antwoordpercentages aan ten aanzien van de knelpunten die volgens de verpleeghuisartsen een rol zouden kunnen spelen met betrekking tot weefseldonatie in het verpleeghuis. De items 'onvoldoende kennis van artsen over weefseldonatie' en 'het weigeren van toestemming, doordat patiënten of betrokkenen niet bekend zijn met de mogelijkheden', scoorden hoog (respectievelijk 73 en $80 \%)$. Daarbij zagen $170(78 \%)$ responderende artsen de donatieprocedure ook als een taakverzwaring.

\section{Directies}

Ongeveer driekwart van de responderende directies $(\mathrm{n}=212)$ gaf aan globaal op de hoogte te zijn van zowel de huidige donorwetgeving $(165 ; 78 \%)$, als de veranderingen in het kader van de nieuwe wetgeving (151; 71\%). De Stichring Eurotransplant was bij de meeste directies bekend (201; 95\%); de Stichting, Bio Implant Services daarentegen niet: $17(8 \%)$ wisten van het bestaan ervan.

In 20 verpleeghuizen had wel eens weefseldonatie plaatsgevonden. In 1 (4\%) verplecghuis bleken er contouren van een beleid met betrekking tot donatieprocedures aanwezig te zijn. Het merendeel van de directies gaf aan te verwachten dat er in de toekomst meer positieve wilsbeschikkingen zouden komen van patiënten die bij overlijden donor zouden willen zijn.

220 Wanneer wij kijken naar de donatie-artitude van verpleeghuisdirecties bleek zowel een groot deel voorstander van orgaandonatie in het algemeen (167; 79\%) te zijn, alsook de bereidheid te hebben om zelf donor te zijn $(148 ; 70 \%)$. In het verlengde hiervan was het merendeel van de directies $(187 ; 88 \%)$ ook bereid om ondersteuning te bieden aan hun medische dienst: wanneer donatieprocedures in de toekomst een vaste plaats zouden gaan innemen in het verpleeghuis.

Ook werd aan de directies gevraagd of de in tabel 3 aangegeven factoren belemmerend zouden kunnen zijn voor donatieprocedures in het verpleeghuis. Opnieuw werd een rol aan alle items toebedeeld en scoorden de items 'weigering van toestemming voor donatie' en 'gebrekkige kennis van artsen' het hoogst (respectievelijk $151(71 \%)$ en $93(44 \%))$.

\section{BESCHOUWING}

De implementatie van de nieuwe Wet op de Orgaandonatie zal er mogelijk toe leiden dat verpleeghuizen in de toekomst meer met weefseldonatie te maken gaan krijgen.

In Nederland en in het buitenland is tot op heden slechts in geringe mate onderzoek gedaan naar het totale potentieel aan weefseldonoren. ${ }^{5}$ Verpleeghuizen zijn daarbij altijd buiten beschouwing gebleven. Met dit onderzoek is enerzijds getracht om een globale indruk te geven van het aantal potentiële huid- en/of corneadonoren in verpleeghuizen en anderzijds om een beeld te schetsen van de kennis en attitude van zowel verpleeghuisartsen als -directies met betrekking tot orgaan- of weefseldonatie, alsmede van hun taxatie met betrekking tot eventuele knelpunten hierbij.

Uit ons onderzock blijkt alleen een deel van de somatische pariënten in aan- 


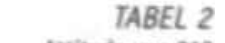

Attitude van 218 verpleeghuisartsen

(8) ten aanzien van donatie in het

algemeen es weefseldonatie in het verpleeghuis. 1997

TABEL 3

Antwoorden van de responderende verpleeghuisartsen $(n=218)(4)$ ten aanrien var knelpunten die een rol rouden kunnen spelen bij weefseldonatie in verpleeghuizen

\begin{tabular}{lrr} 
& $\begin{array}{l}\text { Lonatie } \\
\text { Houding }\end{array}$ & $\begin{array}{l}\text { donatie } \\
\text { in het werplenghuis algemen }\end{array}$ \\
\hline positief & $140(64)$ & $20(9)$ \\
neutraal & $52(24)$ & $185(85)$ \\
negatief & $26(12)$ & $13(6)$ \\
\hline
\end{tabular}

-

gebrekkige motivatie van directies

onvoldoende financiele middelen

onvoldoende kennis van artsen over

weefseldonatie

weigeren van toestemming voor

donatie door:

$\begin{array}{lrrr}\text { hoge leeftijd } & 118(54) & 63(29) & 37(17) \\ \text { geloofsovertuiging } & 94(43) & 72(33) & 74(34) \\ \text { onbekendheid mogelijkheden } & 174(80) & 15(7) & 28(13) \\ \text { angst voor minder goede behandeling } & 68(31) & 92(42) & 59(27)\end{array}$

merking te komen voor donatie van huid en/of cornea. Op basis van uitsluitingen aan de hand van contra-indicaties en leeftijdscriteria zou eenkwart van de overleden somatische verpleeghuispatiënten (circa 2700 in 1995) potenticel donor kunnen zijn. In 1995 werden in Nederland in totaal 1415 cornea- en 346 huiddonaties geëffectueerd. ${ }^{13}$ Met deze getallen als uitgangspunt kan het aangegeven donorpotentieel onder somatische verplecghuispatiënten dus zeker de moeite waard zijn.

Ten aanzien van weefseldonatie door psychogeriatrische patiënten is de situatie geheel anders. Op basis van de medische contra-indicaties komen zij hiervoor nauwelijks in anmerking. Inmiddels is dan ook besloten om deze groep vooralsnog buiten het bestek van de WOD te laten.

Hoewel dit donorpotentieel berekend is op basis van een nauwkeurige bewerking van SIVIS-gegevens, zijn er toch enige beperkingen. Zo verloopt de SIVIScodering van oorzaken van overlijden niet exact hetzelfde als bij het CBS gebruikelijk is en heeft de gehanteerde lijst van contra-indicaties een gedeeltelijk ander begrippenkader dan de SIVIS-diagnoselijst." Onderrapportage van absolute en relatieve contra-indicaties is mogelijk, omdat artsen voornamelijk de: diagnosen invullen die voor het overlijden relevant zijn. Verder zijn beide registraties afhankelijk van de nauwkeurigheid waarmee artsen de registraticformulieren invullen; dit is ook een potentiële foutenbron. Bovendien is het nog. niet duidelijk wat de daadwerkelijke donatiebereidheid van verpleeghuispatiënten is. Verder onderzoek is dan ook nodig om gedetailleerder inzicht te krijgen in het donorpotentieel en de donatiebereidheid.

Uit de enquête blijkt dat zowel verpleeghuisartsen als -directies slechts beperkt op 
de hoogte waren van de donorwetgeving en van orgaan- en weefseldonatie. Kennisvergroting op dit gebied is dan ook een voorwaarde voor de implementatie van de WOD in verpleeghuizen.

Door beide onderzoeksgroepen werd op een aantal knelpunten gewezen. In het bijzonder het weigeren van toestemming voor donatie (door de patiënt zelf of diens vertegenwoordiger) alsmede de nog gebrekkige kennis van verpleeghuisartsen scoorden hier hoog. De grondhouding van de directies ten aanzien van weefseldonatie in het verpleeghuis leek wat positiever te zijn dan die van de artsen, die zich hieraangaande nog overwegend neutraal opstellen. Mogelijk zal de houding van verpleeghuisartsen in de toekomst veranderen, wanneer bij hen meer kennis aanwerig is en er iets aan de knelpunten wordt gedaan.

Dit onderzoek werd uitgevoerd in opdracht van en met subsidie van het Ministerie van Volksgezondheid, Welzijn en Sport. De data werden geanalyseerd door het NZi. 


\section{LITERATUUR}

1. Wet op de organdonatic. Sausblad 19960370.

2. Ministerie vas Volkserondheid. Wedzije en Sport (VWS). Circulaire an ansen in Nederland beureffende de Wet op de organdonatic. CS7JPD-968752. Ripwijk: Ministcrie van VWS; 1996.

3. Wever LJS. Orgaandonatic, her juridisch bades, In: Wead HBM van. Slooff MJH. Goor H van, redacteuren. Organdonaric. 1e de. Houten: Bohn Stafleu Van Loghum: 1998. p. 13-21.

4. Stichting Bis Implant Services (BIS). Voorlopige jaraifers 1998. Leident BIS; 1999.

5. Jager KJ. Pol CC van der, Ooms ECM. Lim St. Kaptijn HH. Prsijn GG. Aantal potenticle hoornvlies,

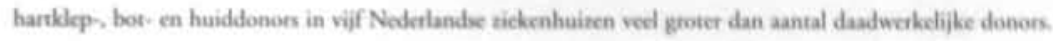
Ned Tijduchr Genecold 1994:138:614-8.

6. Vehmeyer SBW, Brand II van den. Wecfeddonatic. Nederlande Tijduchrift voot Intensive Care 1998:13:4-5.

7. Protocol Orgaan-/Weefieldonatic. Utreche Nederlandse Transplantatie Vereniging en Centraal Begecicidingsorgan woor de Interoollegiale Tocesing 1997.

8. Kalter ESJ. Evaluatie van de weefiddonor, In: Weal HBM van, Slooff MJH, Goor H van, redacteuren. Orgaandonatic. Ie dr. Houten: Bohn Srafleu Vas Loghume 1998, p. 170-5.

9. Jongh EJC de. De Wer orgaandonatie. Voorlopig sluissuk van een emorioned beladen discusie. Medisch Contact 1996;51:1289-91.

10. Zoelen AAJ van, Wintels PMAE, Gurp MEG van, Cleiren MPHD, Hoom W van, Kamp L,Th van der, et al. Vragen om donatie, ecn literatuurondernock. Leiden: Rijksuniversiteit Leiden; 1996.

11. SIG Zorginformatic. Jarbock 1995. Utreche SIG Zorginformatie 1996

12. SIG Zorginformatic. Handbock SIVIS-rogistratic. Utrecht: SIG Zorginformatie: 1997

13. Jaarveralag Stichting BIS Nederland. Leiden: Stiching Bio Implant Services; 1995

14. Aangenendr-Siegers IP, Cools HJM. Doodsoorzaken in verplecghuizen. Ned Tijdschr Genceskd 1992 136:2015-7. 



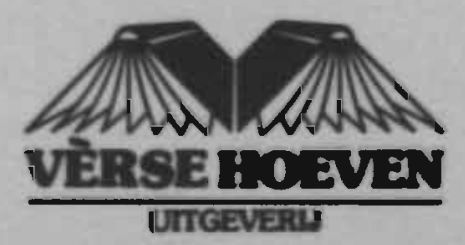

